\author{
UNIVERSIDADE DE SÃO PAULO \\ FACULDADE DE FILOSOFIA, LETRAS E CIÊNCIAS HUMANAS \\ DEPARTAMENTO DE HISTÓRIA \\ PROGRAMA DE PÓS-GRADUAÇÃO EM HISTÓRIA SOCIAL
}

JOSÉ ROBERTO DOS SANTOS

\title{
História e música em São Paulo no início do século XX: A trajetória da Banda da Força Pública (VERSÃO CORRIGIDA)
}


JOSÉ ROBERTO DOS SANTOS

\title{
História e música em São Paulo no início do século XX: A trajetória da Banda da Força Pública (VERSÃO CORRIGIDA)
}

\author{
Dissertação apresentada ao Departamento \\ de História da Faculdade de Filosofia \\ Letras e Ciências Humanas da \\ Universidade de São Paulo para obtenção \\ do título de Mestre em História \\ Área de Concentração: História Social
}

Orientador:

Prof. Dr. José Geraldo Vinci de Moraes 
Autorizo a reprodução e divulgação total ou parcial deste trabalho, por qualquer meio convencional ou eletrônico, para fins de estudo e pesquisa, desde que citada a fonte.

Catalogação na Publicação

Serviço de Biblioteca e Documentação

Faculdade de Filosofia, Letras e Ciências Humanas da Universidade de São Paulo

Santos, José Roberto dos
S237h História e música em São Paulo no início do século

XX: A trajetória da Banda da Força Pública / José

Roberto dos Santos ; orientador Prof. Dr. José

Geraldo Vinci de Moraes. - São Paulo, 2019.

$257 \mathrm{f}$.

Dissertação (Mestrado) - Faculdade de Filosofia, Letras e Ciências Humanas da Universidade de São

Paulo. Departamento de História. Área de concentração: História Social.

1. Banda de música. 2. Força Pública. 3. Cultura paulistana. 4. Anos 1890-1930. 5. História da cultura. I. Moraes, Prof. Dr. José Geraldo Vinci de , orient. II. Título. 
UNIVERSIDADE DE SÃO PAULO

FACULDADE DE FILOSOFIA, LETRAS E CIÊNCIAS HUMANAS

\section{ENTREGA DO EXEMPLAR CORRIGIDO DA DISSERTACCÃO/TESE \\ Termo de Ciência e Concordância do (a) orientador (a)}

Nome do (a) aluno (a): José Roberto dos Santos

Data da defesa: 24/maio/2019

Nome do Prof. (a) orientador (a): Prof. Dr. José Geraldo Vinci de Moraes

Nos termos da legislação vigente, declaro ESTAR CIENTE do conteúdo deste EXEMPLAR CORRIGIDO elaborado em atenção às sugestões dos membros da comissão Julgadora na sessão de defesa do trabalho, manifestando-me plenamente favorável ao seu encaminhamento e publicação no Portal Digital de Teses da USP.

São Paulo, 12/Junho/2019

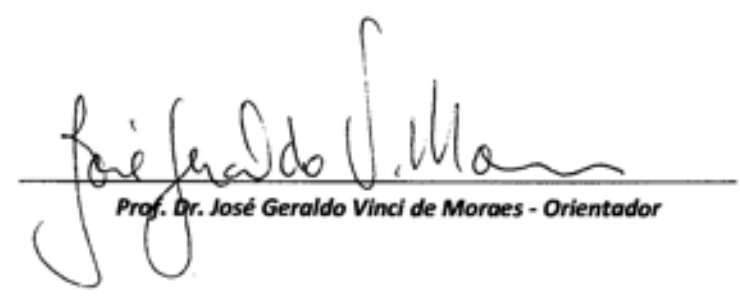


Nome: SANTOS, José Roberto dos

Título: História e música em São Paulo no início do século XX: A trajetória da Banda da Força Pública

Dissertação apresentada ao Departamento de História da Faculdade de Filosofia Letras e Ciências Humanas da Universidade de São Paulo para obtenção do título de Mestre em História

Aprovado em:

Banca Examinadora

Prof. Dr.

Julgamento:

Prof. Dr.

Julgamento:

Prof. Dr.

Julgamento:
Instituição:

Assinatura:

Instituição:

Assinatura:

Instituição:

Assinatura: 


\section{Agradecimentos}

Agradeço à Universidade de São Paulo e especialmente a meu orientador Prof. Dr. José Geraldo Vinci de Moraes, que, com ímpar maestria conseguiu transformar uma simples ideia em um trabalho de pesquisa através de seus conselhos e orientações, dosadas pela paciência e sabedoria que apenas os mestres (com toda a veracidade que esse termo possa ter) possuem. Jamais conseguirei exprimir em palavras o que sinto e senti ao longo de sua orientação.

Meu muito obrigado à Profa. Dra. Virgínia Bessa e Prof. Dr. Paulo Castagna, pelos empolgantes conselhos e ideias propostas no exame de qualificação, que em muito me ajudaram a lançar novos olhares sobre a análise dos dados e suas interpretações e interações. Suas correções se transformaram, ao longo do caminho, em trilhas pavimentadas pelas quais conseguimos seguir, e possibilitaram também a abertura de picadas que poderão ficar abertas para historiadores futuros em busca de um melhor entendimento desse difícil universo das bandas de música. À Profa. Dra. Lilia Moritz Schwarcz assim como à Profa. Dra. Mayra Laudana, pelos valiosos conhecimentos compartilhados em suas disciplinas.

Expresso minha gratidão também ao Prof. Dr. Alberto Ikeda, que, no segundo semestre de 2012, me acolheu no Instituto de Artes da Universidade Estadual Paulista (UNESP), para o qual eu havia rumado com uma imensidão de dúvidas e um sonho.

A todos os artistas - maestros e músicos - do Corpo Musical, aos funcionários do Museu da Polícia Militar do Estado de São Paulo, Arquivo Histórico Municipal, Arquivo Público do Estado minha gratidão. Colecionadores de discos Cap. João Marques, Miguel Braghioni de Porto Ferreira, Miguel Nirez de Fortaleza CE e ao Instituo Moreira Salles (Rio de Janeiro), na pessoa de Euler Gouvêa, pelos arquivos digitais que compõem os Cds que encartam esta dissertação, também agradeço muito, pois, sem sua colaboração, jamais o trabalho chegaria a este provisório termo. Agradeço também à Ana Paula Renesto pelas revisões, transformando um texto "barroco feito um concerto grosso" em algo próximo a Debussy, mais audível ao leitor.

A meu pai, "seu" Toninho (In memoriam), e a D. Laide, devo o gosto pela música caipira e o amor que nunca me faltou. A meu irmão, Marco Antônio dos Santos, historiador 
mais velho da família, devo o início do gosto pela música popular brasileira e a admiração pela história ainda na adolescência. O segundo desses gostos somente desabrocharia nesta idade madura. Aos três, além disso, ainda devo o porto seguro da família.

A Matheus, meu filho amado, agradeço os ensinamentos sobre o uso das ferramentas da informática, cada vez mais indispensáveis, além das ideias e da paciência em ensinar-me. A formatação dos arquivos de áudio, os Cds, os templates e tudo e mais um pouco também estão no pacote de dívidas. Sou e sempre serei eterno aprendiz de teu amor.

Sandra, amiga, companheira, e amor da vida inteira, este trabalho é dedicado a ti. 


\section{RESUMO}

SANTOS, José Roberto dos. 2019. História e música em São Paulo no início do século XX: A trajetória da Banda da Força Pública. 257 fls. Dissertação (Mestrado em História Social) - Faculdade de Filosofia, Letras e Ciências Humanas. Universidade de São Paulo, São Paulo, 2019.

Esta pesquisa investiga o cenário musical paulistano entre os anos 1890 e 1930 tendo como referência o papel especial que desempenharam as bandas de música. Foi extraordinária a presença delas no cotidiano da cidade neste período, tanto para a divulgação musical como para as práticas de formação e profissionalização dos músicos. De certo modo, elas funcionaram como uma espécie de corporação de ofício, constituindo-se um dos raros espaços de aprendizagem profissional para a população mais pobre. Por outro lado, elas também foram instrumentos privilegiados de divulgação musical em uma época anterior à expansão dos meios eletrônicos de difusão. Neste amplo universo se destacou principalmente a Banda de Música da Força Pública do Estado de São Paulo, cuja trajetória é o foco central desta dissertação. É sobretudo a partir dela que são recuperadas práticas musicais na cidade, as inúmeras formas de difusão, os repertórios, as mudanças de gostos, as relações com o público, os processos de formação dos músicos e assim por diante. A partir das décadas de 1920 e 1930 a relação dos paulistanos com as bandas, sobretudo da Força Pública, começou a mudar substancialmente com os avanços das indústrias fonográfica e radiofônica. Apesar da relativa presença de algumas delas nestes novos meios de produção e divulgação, a maior parte desapareceu e a militar, especialmente, teve suas representações e funções culturais e musicais muito reduzidas. É esta rara dinâmica de transformações da cultura musical paulistana tendo como fio condutor a Banda da Força Pública que esta dissertação quer captar e compreender.

Palavras-chave: Banda de Música. Força Pública. Cultura paulistana. Anos 1890-1930. História da cultura. 


\begin{abstract}
SANTOS, José Roberto dos. 2019. History and music in Sao Paulo city in the early 20th century: The trajectory of Banda da Força Pública. 257 p. Thesis (Master's in Social History) - Faculdade de Filosofia, Letras e Ciências Humanas. Universidade de São Paulo, São Paulo, 2019.

This research focuses on the musical setting of Sao Paulo city from the 1890s to the 1930s and the special role of bands, whose presence in the daily life of the city was remarkable both for the dissemination of music and the professional training and practice of musicians. Bands worked as a kind of craft corporation and were one of the few possibilities of professional learning for the poorest population. In addition, bands were also privileged instruments of dissemination of music in a time prior to the expansion of electronic broadcasting. In this broad context, Sao Paulo State Public Force Music Band [Banda de Música da Força Pública do Estado de São Paulo] stood out. Having the trajectory of this band as its central focus, this master's thesis recovers the musical practices of São Paulo city, the innumerable forms of dissemination of music, repertoires, changes in tastes, relations with the public, the training of musicians, and so on. Since the 1920s and 1930s the relationship of Sao Paulo city inhabitants with the bands, and especially with the Public Force Band, began to change substantially due to the advances of the phonographic and radiophonic industries. Despite the relative presence of some of these bands in these new means of production and dissemination, most of them have disappeared. The cultural and musical representations and the functions of the Public Force Music Band have also decreased. Having the Public Force Band as its guiding thread, this thesis has sought to capture and understand this rare dynamics of transformations of the musical culture of São Paulo city.
\end{abstract}

Keywords: Music Band. Public Force. Culture of Sao Paulo city. Years 1890-1930. History of culture. 


\section{LISTA DE FIGURAS}

Figura 1: Mapa do centro da cidade de São Paulo - 1890...........................................29

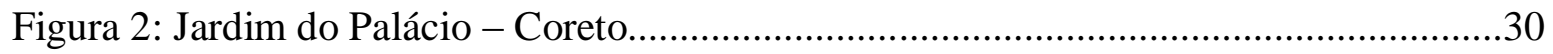

Figura 3: Jardim do Palácio - Parada - 1905 ou 1906.......................................................31

Figura 4: Mapa do centro da cidade de São Paulo - 1916................................................34

Figura 5: Gráfico reprentativo das categorias de bandas de música encontradas na cidade de

São Paulo entre os anos de 1889 e 1932 em percentuais e números absolutos..57

Figura 6: Gráfico dos compositores mais executados durante o ano de 1903 pela Banda de

Música da Força Pública em concertos......................................................77

Figura 7: Gráfico das obras mais executados durante o ano de 1903 pela Banda de Música da

Força Pública em concertos........................................................................77

Figura 8: Gráfico dos gêneros mais executados durante o ano de 1903 pela Banda de Música da Força Pública em concertos .......................................................................80

Figura 9: Gráfico dos compositores mais executados durante o ano de 1915 pela Banda de Música da Força Pública em concertos.........................................................81

Figura 10: Gráfico das obras mais executadas durante o ano de 1915 pela Banda de Música da Força Pública em concertos..................................................................... 81

Figura 11. Gráficos dos gêneros mais executados durante o ano de 1915 pela Banda de Música da Força Pública em concertos.........................................................82

Figura 12. Gráfico dos compositores mais executados durante os anos de 1925 a 1930 pela Banda de Música da Força Pública em concertos

Figura 13. Gráfico das obras mais executadas durante os anos de 1925 a 1930 pela Banda de Música da Força Pública em concertos. .85

Figura 14. Gráfico dos gêneros mais executados durante os anos de 1925 a 1930 pela Banda de Música da Força Pública em concertos.....................................................86

Figura 15. Gráfico comparativo dos gêneros mais executados 1903/ 1915/ 1925-30 pela Banda de Música da Força Pública em concertos..............................................8

Figura 16. Grupo Excêntrico - Jazz Band do Teatro Polytheama do Braz...........................102

Figura 17. Jazz Band Cruz Azul. Força Pública do Estado de São Paulo.............................103 
Figura 18. Banda de Música do $5^{\circ}$ Batalhão de Infantaria da Força Pública do Estado de São

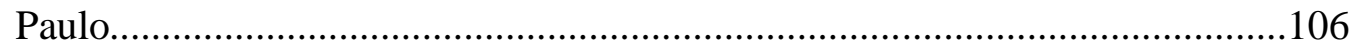

Figura 19. Banda de Música da Força Pública do Estado de São Paulo. 1918-1920..........172

Figura 20. Selo comemorativo N 108417 Odeon Record - Banda da Força Pública do Estado de São Paulo: Marcha dos Croatas....................................................................174

Figura 21. Banda de Música da Guarda Civil de São Paulo 1931....................................... 187

Figura 22. Banda de Música da Força Pública do Estado de São Paulo. Desfile cívico militar

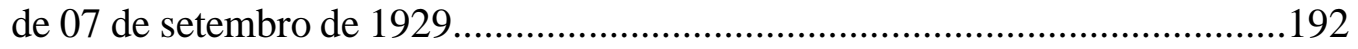

Figura 23. Banda de Música da Força Pública do Estado de São Paulo na parada militar de

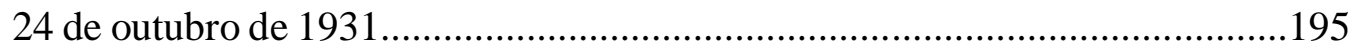




\section{LISTA DE TABELAS}

Tabela 1 - Bandas de música encontradas na cidade de São Paulo entre 1889 e 1932 por

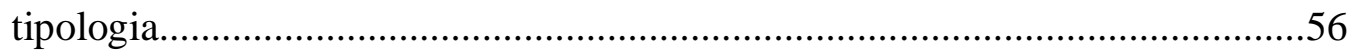

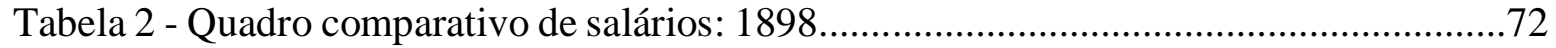

Tabela 3 - Quadro comparativo de salários: 1902 .........................................................73

Tabela 4 - Quadro comparativo de salários: 1906 ......................................................73

Tabela 5 - Quadro comparativo de salários. 1911 e 1912 .................................................73

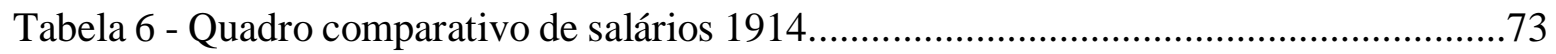

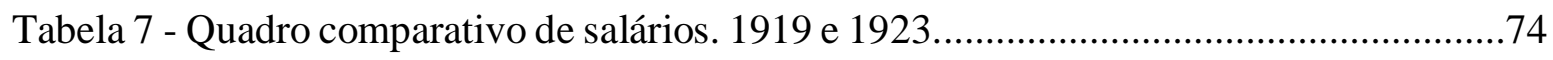

Tabela 08 - Repertório da Banda da Força Pública 1903 ................................................219

Tabela 09 - Repertório da Banda da Força Pública 1915...............................................224

Tabela 10 - Repertório da Banda da Força Pública 1925 ................................................226

Tabela 11 - Repertório da Banda da Força Pública 1926.................................................227

Tabela 12 - Repertório da Banda da Força Pública 1927.................................................229

Tabela 13 - Repertório da Banda da Força Pública 1928..................................................230

Tabela 14 - Repertório da Banda da Força Pública 1929................................................233

Tabela 15 - Repertório da Banda da Força Pública 1930..............................................235

Tabela 16 - Mapeamento das Bandas de música encontradas na cidade de São Paulo entre o período de 1888 e 1932 ...................................................................................2236

Tabela 17 - Comandantes/maestros da banda da Força Pública do estado de São Paulo .241

Tabela 18 - Discografia geral encontrada de bandas de música entre os anos de 1904 e 1932. .243

Tabela 19 - Discografia da banda da Força Pública do estado de São Paulo entre os anos de 1904 e 1932 


\section{SUMÁRIO}

INTRODUÇÃO

CAPÍTUlo 1: AS BANDAS DE MÚSICA NA CIDADE DE SÃo PAULO (1889 1930) .20

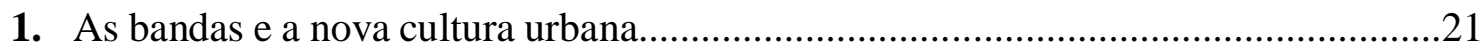

2. Os espaços na cidade ocupados pelas bandas..........................................................26

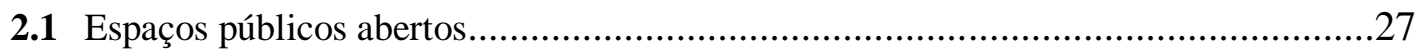

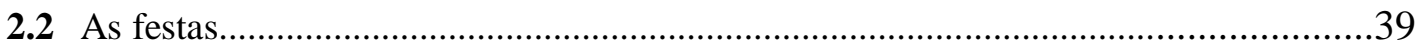

2.3 Outras comemorações...........................................................................................4

2.4 Espaços públicos fechados..................................................................................51

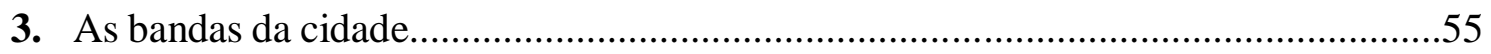

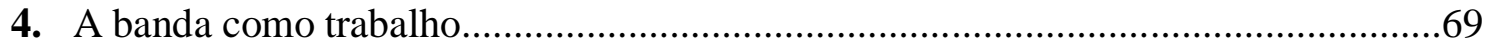

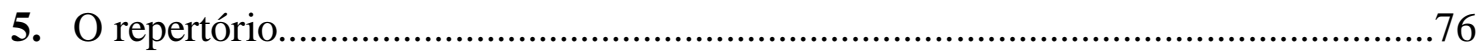

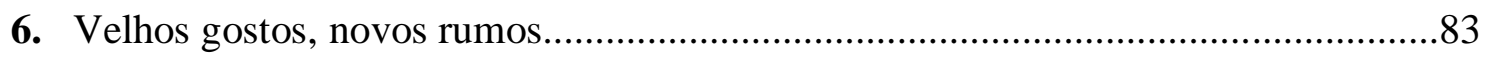

CAPÍTULO 2: UM PANORAMA MUSICAL PAULISTANO_......................................92

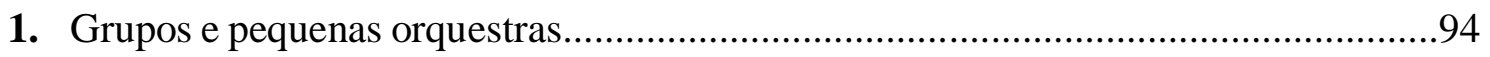

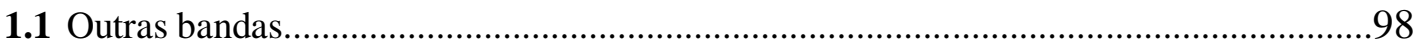

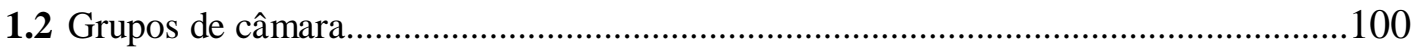

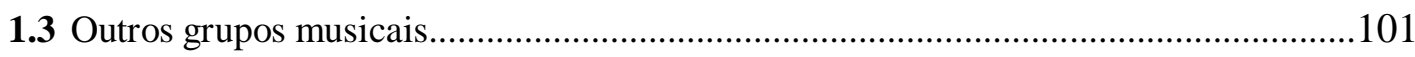

2. A formação dos músicos.....................................................................................104

2.1 Professores e escolas de música..................................................................................110

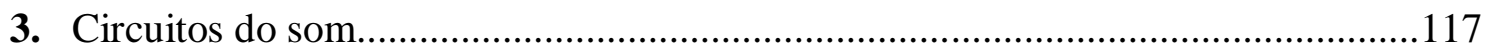

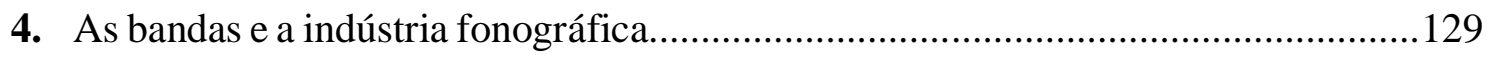

CAPÍTULO 3: A TRAJETÓRIA DA BANDA DA FORÇA PÚBLICA........................142

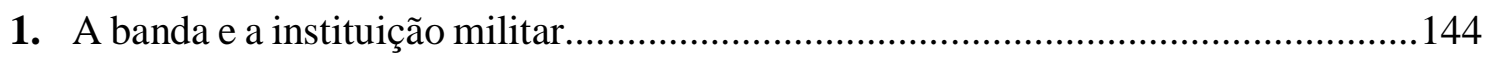

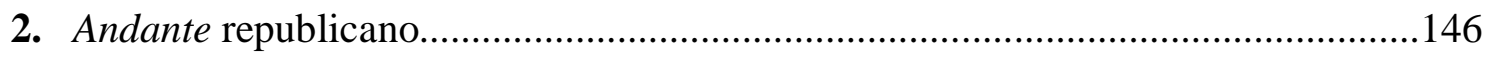

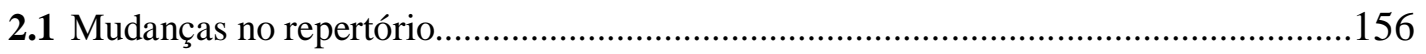


3. Allegro: a importância da Missão Francesa..........................................................160

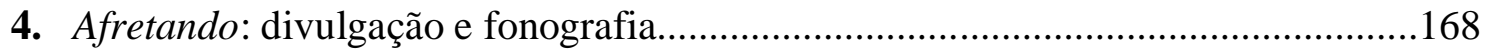

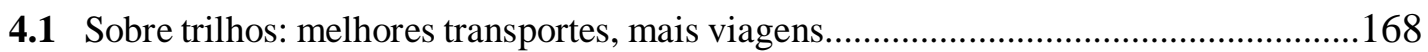

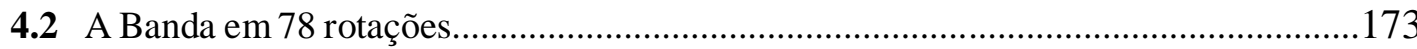

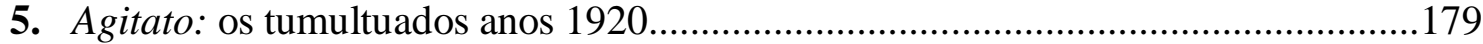

6. Presto: as turbulências políticas interna e externa dos 1930 ...................................193

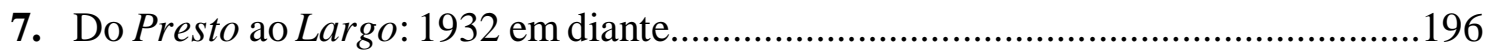

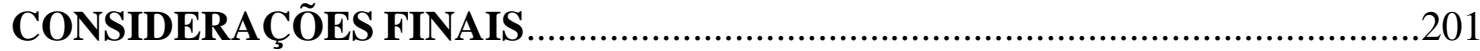

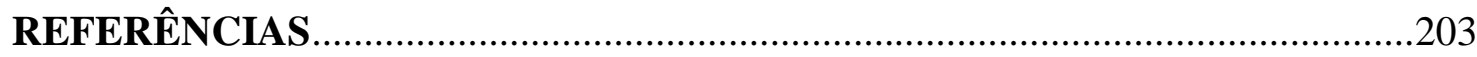

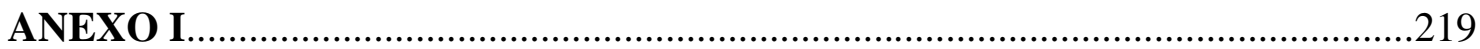

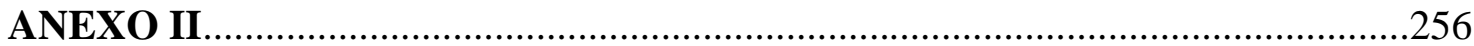




\section{INTRODUÇÃO}

Músicos a postos: afinar a banda!

Entre o final do século XIX e início do XX, a cidade de São Paulo experimentou intensas transformações. Tal movimento implicou a ativação de diversas áreas, incluindo o circuito das culturas urbanas, com a presença cada vez mais marcante de espetáculos musicais que ocorriam em locais públicos ou nos recintos fechados privados, como clubes, teatros, residências e associações. Nesse novo cenário urbano, as bandas de música tiveram presença importante como apontou José Geraldo Vinci de Moraes:

Em São Paulo, a importância das bandas se dá em diversos níveis: o primeiro, sem dúvida alguma, está relacionado com a formação e manutenção dos músicos de condições financeiras precárias, que tinham nas bandas um modo de aprender e estudar música ao mesmo tempo em que exerciam a profissão. Assim, origina-se uma outra contribuição extremamente relevante pois, tratou-se na prática da primeira organização musical que permitiu ainda de forma precária e incipiente, a profissionalização do músico popular. Além disto, tornou-se uma potente fonte de difusão da música popular e divulgadora da música erudita. ${ }^{1}$

Apesar disso, esse universo das bandas de música em São Paulo permaneceu ainda pouco explorado pela historiografia de modo geral e pela música em particular. Esta investigação pretende justamente contribuir para ampliar as discussões em torno do tema.

Um primeiro aspecto discutido por essa pesquisa foi a importância das bandas para a formação de músicos populares. Oriundos das camadas mais pobres da população, esses artistas encontravam nas corporações musicais a oportunidade de receber algum ensino e qualificação profissional. Outro aspecto importante foi o papel que elas desempenharam na divulgação da cultura musical de concerto, pois grande parte do repertório era composto por árias de óperas, aberturas, sinfonias completas ou trechos e movimentos. Como o público que assistia às apresentações abertas era muito diversificado, a circulação e recepção dessas obras era variada também, o que concedia às bandas um perfil de intermediárias culturais.

\footnotetext{
${ }^{1}$ MORAES, J. G. Vinci de. Sonoridades Paulistanas: a música popular na cidade de São Paulo - final do século XIX ao início do século XX. Rio de Janeiro: Funarte, 1997, p.158.
} 
Entre as bandas de música, despontaram no caso carioca, por exemplo, bandas militares como as do exército brasileiro, das unidades da marinha e suas escolas militares, que foram amplamente reportadas pela literatura e noticiadas na grande imprensa de época, prestando serviços dentro e fora da caserna, exercendo o papel de formar músicos e servindo de referência às demais bandas civis. Ainda no Rio, corporações musicais de Batalhões da Força Policial também são mencionadas, mas a principal referência da Capital Federal foi sem dúvida a Banda do Corpo de Bombeiros, que, regida pelo maestro Anacleto de Medeiros, deixou um histórico invejável de gravações em discos, além de farta documentação e literatura, permanecendo ativa até os dias de hoje.

Já no caso de São Paulo, pouco ainda se sabe sobre essas corporações musicais que habitaram a cidade em um momento crucial de transformação. O que se pode afirmar é que há indícios de uma intensa atividade musical na cidade naquele momento, na qual as bandas de música tomavam parte de forma sistemática como organismos vivos que alimentavam e eram alimentadas por toda essa dinâmica. Durante a segunda metade do século XIX, as bandas militares mais proeminentes que atuaram e disputaram os espaços da cidade foram a da Guarda Nacional, do $10^{\circ}$ Regimento de Cavalaria do Exército brasileiro e a Banda de Música da Guarda Municipal Permanente. ${ }^{2}$ Com relação às bandas civis, o destaque da historiografia se concentra na Corporação Musical Operária da Lapa."3

Curiosamente esta investigação identificou um número relativamente grande de corporações, corroborando os indícios de existência de práticas musicais variadas e sedimentadas na cidade por esses conjuntos. Bandas civis como Ettore Fieramosca, Giuseppe Verdi e Bersaglieri, cujos nomes indicam claramente a presença das culturas imigrantes, tiveram papel destacado na cidade. Porém, grupos alemães, franceses, portugueses, espanhóis e sobretudo italianos, também mantiveram suas bandas de música como as citadas acima. Elas e outras tantas aparecem quantificadas e tiveram, na medida em que os vestígios permitiram, suas origens associativas rastreadas. No transcorrer do trabalho, será possível observar tabela e gráfico que apontam as bandas de música encontradas na pesquisa e classificadas por categorias.

\footnotetext{
${ }^{2}$ Posteriormente Corpo Policial Permanente, Corpo Militar de Polícia, Força Policial e Força Pública.

${ }^{3}$ SILVA, Juliana Soares da Costa. Práticas musicais, comunidade, localidade e velhice: um estudo etnográfico sobre a Corporação musical operária da Lapa.2018. p. 43-44. Dissertação (Mestrado) - Instituto de Artes, Universidade Estadual de Campinas, Campinas.
} 
Esta investigação detém-se especificamente na Banda de Música da Força Pública do Estado de São Paulo, grupo no qual foi possível encontrar características próprias das bandas que existiram àquela época. Observada mais de perto, a Banda suscitou inquietações investigativas, como por exemplo: o que justificaria a existência de uma banda de música em uma corporação policial? Como esse grupo pôde se sustentar durante 162 anos, chegando aos dias atuais? Quais as funções que esse grupo musical desempenhou dentro do universo musical paulistano? Quais as relações sociais e profissionais que se estabeleceram entre este grupo e as demais bandas da cidade? Quem foram os agentes que tomaram parte nessa corporação? Como foi o relacionamento da Banda com a indústria fonográfica? A tentativa de compreender essa corporação musical, respondendo a essas e tantas outras perguntas, transformou a Banda da Força Pública no objeto central da pesquisa.

O caminho metodológico adotado para penetrar nesse passado ainda desconhecido foi obrigatoriamente variado. A grande imprensa, em especial os jornais Correio Paulistano e $O$ Estado de São Paulo, foram fontes para conhecer o cotidiano da cidade e suas manifestações musicais. Valendo-me de edições que variaram de 1857 a 1930, foi possível compreender melhor as atividades musicais desenvolvidas na cidade naquele período e entender a dinâmica das bandas. A partir das informações apuradas na imprensa, foi organizado um banco de dados com os repertórios apresentados, os compositores mais tocados e assim por diante. Os dados são apresentados quantitativamente por meio de gráficos, que possibilitam entender o funcionamento das bandas como instrumento mediador de um repertório de concerto ao público simples da cidade. Os dados também permitem observar as mudanças que se consolidaram nesse repertório. Em face das mudanças, surgiram indagações a respeito da nova dinâmica de trabalho dessas bandas. Como se davam os contratos para a prestação dos serviços? Qual a capacidade de apresentações de cada corporação? Quanto as bandas cobravam por apresentação? Quanto os músicos ganhavam? Seus salários eram bons, se comparados aos das demais profissões urbanas? Era possível sobreviver como músico de banda naquele momento? Conseguiu-se compreender que o ofício da música sempre representou uma luta entre o idealismo e o pragmatismo por parte dos profissionais que o exerceram. Com a ajuda de outras tabelas sobre os salários, foi 
possível compreender essa difícil dinâmica de sobrevivência, em que o músico precisava sempre exercer várias atividades em concomitância à de instrumentista.

Também foram consultados inúmeros documentos oficiais, sobretudo os relativos à Banda da Força Pública. Nesse sentido, os Boletins Gerais da Força Pública do Estado de São Paulo ${ }^{4}$ localizados no Museu da Polícia Militar do Estado de São Paulo foram importantes sob diversos aspectos. O Arquivo Histórico da Cidade de São Paulo também teve papel crucial no fornecimento de documentos, como mapas e revistas. O Arquivo da Câmara Municipal de São Paulo também forneceu algumas atas de reuniões para a fundamentação de argumentos e hipóteses. Outra fonte que colaborou nos aspectos jurídicos da Força Pública do Estado de São Paulo foi a base de dados da Assembleia Legislativa do Estado de São Paulo que muito contribuiu para o complemento de informações em face da parca literatura disponível sobre essa Banda de Música.

Também muito limitada é a bibliografia sobre as bandas em São Paulo. A maioria das obras que abordam a temática ainda não a têm como objeto principal de estudo, apenas a tangenciam. ${ }^{5}$ Já a obra de Laura Della Mônica centrada na banda militar é marcante e inauguradora; no entanto, apresenta a Banda da Força Pública como uma corporação heroica, quase idílica. ${ }^{6} \mathrm{O}$ contraponto a essa imagem é obtido pela leitura das críticas da grande imprensa e também dos cronistas e memorialistas como Jorge Americano, Antônio Egydio Martins, Zélia Gatai e Ecléa Bosi, entre outros

Base documental importante foi a seção do arquivo geral (biblioteca de partituras) do atual Corpo Musical da Polícia Militar do Estado de São Paulo, antiga Força Pública. Criado

\footnotetext{
${ }^{4}$ Boletim Geral é um documento de Estado, impresso em papel (hodiernamente também em versão eletrônica), de edição diária (nos dias úteis), pela Força Pública desde 1 de janeiro de 1925, que contém legislação, atos administrativos, determinações e ordens. Dividido em cinco partes, é composto por: Legislação e Organização; Alterações de Pessoal; Assuntos Gerais e Administrativos; Justiça e Disciplina; e Assuntos Civis. Seu acesso foi possível através da Biblioteca do Museu da Polícia Militar do Estado de São Paulo.

5. Como exemplos podem ser citados:

HARDMANN, Francisco Foot. Nem Pátria nem patrão: vida operária e cultura anarquista no Brasil. 2. ed. São Paulo: Brasiliense, 1984;

BINDER, Fernando Pereira. Bandas militares no Brasil: difusão e organização entre 1808 e 1889. 2006. Dissertação (Mestrado) - Instituto de Artes, Universidade Estadual Paulista, São Paulo. volumes I, II, III; TINHORÃO, José Ramos. Os sons que vêm da rua. 2. ed. São Paulo: Editora 34, 2005;

MORAES, J. G. Vinci de. Sonoridades Paulistanas: a música popular na cidade de São Paulo-final do século XIX ao início do século XX. Rio de Janeiro: Funarte, 1997.

${ }^{6}$ DELlA MÔNICA, Laura. História da Banda de Música da Polícia Militar do Estado de São Paulo. São Paulo: Edanee Editora, 1977.
} 
em 1901, tal arquivo revela um acervo composto de obras de todos os gêneros musicais (algumas em formato de transcrições para um grupo desprovido da seção de cordas - com exceção dos contrabaixos).

Finalmente, as fontes sonoras, ainda muito dispersas, começaram a aparecer, sobretudo aquelas ainda em posse de colecionadores particulares, ${ }^{7}$ como também as presentes em instituições culturais privadas, como o Instituto Moreira Salles do Rio de Janeiro. Foi possível, a partir desses vestígios, realizar um levantamento discográfico prévio de quatro bandas de música que viveram na cidade de São Paulo no período de 1902 a 1932: Banda de Música da Força Pública do Estado de São Paulo, Banda de Música Ettore Fieramosca, Banda do Maestro Veríssimo Glória e Banda Musical Giuseppe Verdi de São Paulo. O referido levantamento discográfico gerou duas tabelas que contêm obras (incluindo algumas não catalogadas ainda pela literatura) que poderão auxiliar futuros trabalhos de pesquisa. Nesta dissertação são apresentados 38 fonogramas gravados entre os anos de 1902 e 1932, que podem ser ouvidos na página da web www.memoriadamusica.com.br e nos três Cds que seguem encartados.

O repertório específico da Banda da Força Pública que não corresponde a seus registos fonográficos, é outro ponto investigado neste trabalho, com resultados apresentados em tabelas específicas.

\section{Em busca de possibilidades}

Compreender o processo de transformação cultural da cidade de São Paulo, suas implicações no cenário musical e a profissionalização de suas bandas de música revelou-se, ao longo da pesquisa, tarefa complexa em razão do recorte temporal escolhido. O período aparecia como instigante em razão das profundas transformações econômicas, sociais, artísticas e urbanas.

Cabe ressaltar que, apesar de o foco desta investigação ser a Banda de Música da Força Pública, várias outras se apresentaram para tomar parte no trabalho. A participação dessas bandas nos eventos desenvolvidos na cidade, como festas religiosas, torneios esportivos, inaugurações, recepções e festas em homenagem a autoridades, retretas e

\footnotetext{
${ }^{7}$ Os colecionadores são: Miguel Nirez (Fortaleza - CE), Miguel Braghioni (Porto Ferreira - SP) e Cap. Res. PM João Marques (São Bernardo do Campo - SP).
} 
concertos nos espaços públicos e, como não poderia deixar de ser, também no mercado fonográfico, não deixam dúvidas sobre a existência de uma grande comunidade musical em pleno funcionamento, em vez de poucos grupos.

Durante o desdobramento da pesquisa, as transformações - tanto da Força Pública como de sua Banda de Música - ganharam corpo na narrativa, auxiliando a reconstrução do passado desta. Um exemplo das referidas transformações são aquelas promovidas pelas missões militares francesas de 1906 e 1919, as quais, trazendo uma cultura essencialmente militarista, utilizaram a Banda de Música como instrumento de treinamento para as tropas, impuseram a esta peças de um repertório ainda pouco explorado pelas bandas da cidade, e a estimularam a apresentar-se para além dos quartéis.

À semelhança de um dobrado, este trabalho foi construído em três partes. Iniciando com estes poucos compassos que o anunciam (introdução), segue para a apresentação do tema em "As bandas de música na cidade de São Paulo (1889-1930)" (cap. 1), seu trio, "Um panorama musical paulistano", promove uma visão sobre a São Paulo musical da Primeira República (cap. 2), e retorna ao tema ao abordar “A trajetória da Banda de Música da Força Pública" (cap. 3), desta vez com todas as variações possíveis, colocando em destaque os flautins e as requintas, terminando na coda conclusiva, a qual, na verdade, mais parece uma cadência suspensa.

O capítulo 1 apresenta uma São Paulo onde as ruas exerciam a função de palco para os grupos musicais. Nele, são evidenciados os grupos, seus locais de concerto e as rotinas das apresentações. Há discussão sobre o papel exercido pelos espaços públicos e privados (abertos e fechados) para a circulação musical, bem como o papel das festas religiosas e da imigração na organização das bandas de música da cidade. No âmbito dos espaços públicos, há um passeio pelas tradicionais festas religiosas da São Paulo do início do século XX e é possível entender o relacionamento desses grupos musicais com a Igreja Católica e desta com a população. Já no escopo dos espaços públicos fechados, o aproveitamento das salas de teatro na cidade é outro ponto destacado. Os espaços nem sempre eram democraticamente divididos entre as bandas de música e os grupos formados nesses teatros. Nesta seção, será possível também conhecer, por meio dos resultados gerados pelo banco de dados, o número de corporações musicais mapeadas durante o período da Primeira República. 
No capítulo 2, grupos de todos os tipos, conjuntos de câmara, bandas, orquestras e outras formações - como orquestras de carnaval, de cinema e de teatros - que compunham esse ambiente musical urbano, se destacam. Tais grupos musicais criaram uma rede de profissionais que circularam internamente nesse meio, sobrevivendo à medida do possível. Neste contexto se discute também a formação dos músicos. Outro caminho investigativo foi a ascensão do rádio e suas relações com a indústria fonográfica.

O capítulo 3, traz para a cena central aquela que é a mais antiga banda ativa na cidade de São Paulo: a Banda de Música da Força Pública do Estado de São Paulo. Analisa sua atuação e busca compreender sua estrutura de funcionamento, comando, formação musical, admissão, sistema de promoção e transmissão de conhecimentos musicais.

Banda afinada! Que soe o primeiro acorde! "Pede à Banda pra tocar um dobrado!"8

\footnotetext{
${ }^{8}$ LINS, Ivan; MARTINS, Victor. Somos todos iguais nesta noite. Álbum Somos todos iguais nesta noite. Rio
} de Janeiro: EMI Odeon, 1977. 
Capítulo 1

As bandas de música na cidade de São Paulo (1889 - 1930) 
Pensar no tamanho da diversidade musical existente na cidade de São Paulo durante o último quartel do século XIX e as três primeiras décadas do século XX é algo praticamente impossível diante das dificuldades que as pesquisas apresentam, principalmente em razão das fontes. Na tentativa de compreender um dos aspectos desse cenário cultural - as bandas de música e seu cotidiano -, este capítulo contextualiza essas corporações e seus agentes dentro da cultura musical paulistana, apresentando seus espaços de atuação, as corporações, a dura vida do profissional de música e o repertório como agente da identidade dessas bandas de música. A pesquisa que originou o texto que segue trouxe revelações e surpresas de um universo ainda de certa forma desconhecido e que teimosamente insistiu por muito tempo em assim permanecer, mas que aos poucos começa a dar sinais de existência, revelando-se um mundo a ser descoberto e explorado.

Antes, porém, de nos atermos propriamente às bandas de música da cidade de São

Paulo, é importante a compreensão de que esses grupos representaram apenas uma parcela do universo musical da cidade durante os anos da Primeira República. Conforme nosso entendimento, corroborado pelas fontes, havia uma intensa atividade musical que acontecia na cidade, trazendo uma infinidade de grupos musicais e possibilidades para o músico possibilidades essas que não significavam necessariamente ganhos razoáveis, como veremos. Antes ainda de se compreender tais grupos e em especial as bandas de música, é necessário sobretudo entender como a cidade de São Paulo se transformou entre o último quartel do século XIX e as primeiras décadas do século XX, gerou tais possibilidades de trabalho e desenvolvimento cultural, abrigou a todos e criou essa tão peculiar teia musical, cedendo seus espaços como palco para esses artistas.

\section{As bandas e a nova cultura urbana}

Por ocasião do primeiro ano de instauração da República, as comemorações em 15 de novembro de 1890, na cidade de São Paulo, apresentaram animados festejos. As ruas centrais foram enfeitadas com festões de folhagens, galhardetes e coretos. Muitas casas tiveram o capricho de adornarem suas fachadas, além de embandeirarem suas janelas, como forma de tomar parte na alegria. A Banda do Corpo de Permanentes, regida pelo sargento mestre Bernardo Jorge da Costa, percorreu várias ruas do centro, trajando novo uniforme, e, tendo à frente seu comandante, o coronel Lisboa, dirigiu-se ao Largo do Palácio para que sua 
oficialidade procedesse aos cumprimentos junto ao Governador do Estado. O desfile seguiu enorme e animadíssimo pelas ruas do centro da cidade entre tarde e noite. $\mathrm{O}$ clube carnavalesco Tenentes de Plutão ${ }^{9}$ também se apresentou em passeata, saindo de sua “caverna” na rua Quinze de Novembro às duas horas com seis sócios a cavalo à frente, precedendo a Banda de Música do $10^{\circ}$ Regimento de Cavalaria do Exército. Vários bondes especiais, iluminados por lanternas venezianas, conduziram sócios do referido clube, levaram-nos a um piquenique e, ao final da tarde, trouxeram-nos de volta. Ao cair da noite, os edifícios públicos iluminaram-se, ${ }^{10}$ talvez na tentativa de prolongar as comemorações do primeiro aniversário de um novo tempo.

Esse tipo de manifestação festiva, cívica e popular, tendo como centro as bandas de música, era muito comum nesse período. Elas acompanhavam os festejos religiosos, cívicos, esportivos e tantas outras manifestações populares públicas. $\mathrm{Na}$ realidade, esses conjuntos musicais estão presentes no Brasil desde longa data. Bandas de música ou "Músicas dos Regimentos" em São Paulo são anteriores à chegada da Família Real ao Brasil, em 1808, período anterior àquele por nós analisado. Os grupos musicais que se formaram desde o século XVIII e dos quais se tem notícias prestavam-se a atender aos serviços religiosos e a executar a música das rotinas castrenses ${ }^{11}$ antes que a corte portuguesa aqui desembarcasse. ${ }^{12}$ Para Aloísio de Almeida:

[...] As nossas bandas nasceram da "música do mestre-de-capela" ou das capelas de nossas catedrais e muitas matrizes, pelo abandono das vozes, e reforço da instrumentação de sopro. No mundo inteiro ocidental essa origem é a mesma, com nomes iguais ou pouco diversas. A "música" do mestre-de-capela já saía à rua, quando surgiram as primeiras bandas de música militares, em 1802. Coexistem ambas, sob D. João VI, porque aquela é essencialmente religiosa. Sob Pedro I a orquestra vai para o teatro

\footnotetext{
${ }^{9}$ Tenentes de Plutão era um clube carnavalesco de grande expressão entre os anos de 1890 e início do século XX. Seus concorrentes eram o Democráticos, Girondinos e os Fenianos. Carnaval da Saudade. Correio Paulistano. São Paulo, p. 14, 19 de jan. 1936.

1015 de Novembro. O Estado de São Paulo, São Paulo, p. 2, 18 nov. 1890.

${ }^{11}$ Entende-se por rotina castrense os exercícios de ordem unida, revistas de oficiais e praças de um quartel (Batalhão, Regimento, Brigada), durante os quais, ao som de uma banda ou conjunto, facilita-se a execução de movimentos conjuntos: toques de cornetas anunciando as horas do rancho (refeições), reuniões de oficiais, sargentos, presença ou ausência do respectivo comandante, visitas de autoridades com o devido toque de reconhecimento, e início ou término do expediente administrativo.

${ }^{12}$ MARTINS, Antônio Egydio. São Paulo antigo: 1554 a 1910. São Paulo: Paz e Terra. 2003. p. 235.
} 
preferencialmente, a música de rua deixa os instrumentos de corda, é banda. $^{13}$

Após a chegada da Família Real, o desenvolvimento dos grupos militares ganhou fôlego pela criação da Guarda Nacional e das Guardas Municipais Permanentes a partir de 1831, e houve condições favoráveis para o florescimento e implementação das bandas de música dentro desse ambiente militar. No entanto, esses grupos não se fizeram presentes nem apenas nos quartéis, nem nesse momento. Produto cultural de uma sociedade em desenvolvimento constante, organismo vivo e dinâmico, as bandas testemunharam e compartilharam muitos dos acontecimentos da cidade. A maioria das ruas, viadutos, largos, praças ou prédios inaugurados contou com a presença desses grupos.

Durante todo o período do segundo reinado, o estado de São Paulo experimentou mudanças que se refletiram na dinâmica da capital, sobretudo a partir das duas últimas décadas do século XIX e, naturalmente, em sua cultura, frutos da economia alavancada pelos braços dos imigrantes que chegaram para produzir a riqueza conquistada pelo café. A estrada de ferro levava na ida o indivíduo e traria na volta o fruto dessa produção agrícola rumo ao porto de Santos. Com essa nova população, chegaram também o conhecimento musical, a cultura e as tradições responsáveis pela formação de determinados núcleos específicos de músicos organizados em bandas civis de imigrantes, como as italianas, portuguesas, francesas e alemãs. Dessa efervescência cultural, resultou que, no período entre 1889 e 1930, a cidade de São Paulo registrou um número aproximado de 89 corporações musicais, incluindo, entre elas: bandas militares estaduais (Força Policial) e federais (Forças Armadas incluindo a Guarda Nacional), bandas civis pertencentes a associações, sociedades, irmandades, clubes, agremiações operárias, filarmônicas, companhias equestres, institutos educacionais, escolas diversas, orfanatos, circos e outras.

Para compreender melhor essa dinâmica de transformações da cultura musical paulistana, é preciso colocar em perspectiva que, entre os anos de 1880 e 1900, a cidade provinciana começou a desaparecer, cedendo lugar a uma modernidade composta de bondes elétricos, ruas planejadas, avenidas abertas para receber calçamentos e viadutos, dentro de

\footnotetext{
${ }^{13}$ ALMEIDA, Aloísio de. Folclore da banda de música. Revista do Arquivo Público Municipal, v. CLXXVI, p. 45-79, jan.-mar. 1969.
} 
uma lógica urbana calcada no crescimento da economia cafeeira. Para entender-se melhor essa modernidade, Sterne aponta que:

[...] entende-se por modernização, uma somatória de elementos que confluíram no Ocidente, durante o período estudado: "capitalismo, colonialismo e a ascensão da indústria; o desenvolvimento e o crescimento das ciências, as cosmologias cambiantes, as transformações demográficas (especificamente a migração e urbanização), as novas formas de poder coletivo e corporativo, os movimentos sociais, a luta de classes e o crescimento das novas camadas médias, a comunicação de massa, os estados nacionais, a burocracia; a confiança no progresso, num sujeito humanista universal e abstrato, bem como no mercado mundial; e a contemplação reflexiva do caráter constante da mudança". ${ }^{14}$

São Paulo, cidade de aproximadamente 64.930 habitantes em 1890, cresceu em um ritmo alucinado, chegando a 130.000 em 1895 e alcançando 375.000, em 1910. ${ }^{15}$ Mais gente, maior a necessidade de suprimentos, transportes, saúde e saneamento básico, segurança, empregos, além de mais cultura e diversões. Nesse novo panorama cultural e de práticas de lazer, as bandas de música despontaram como parte integrante da paisagem sonora urbana, reinando absolutas em seu espaço natural: as ruas, praças e jardins públicos.

Hotéis, restaurantes, confeitarias, casas de comércio, lojas de departamentos, farmácias, armazéns, lojas de tecidos, cafés, cafés-concerto, bares, cabarés, indústrias, e bancos começaram a florescer e a se multiplicar, impulsionados, nessa São Paulo dos 1900, pelo capital excedente do café, na tentativa de diversificação de investimentos por parte da elite agrária paulista. Nesse compasso de dinamização da economia, a cidade mudou radicalmente, o que favoreceu também a demanda de prestação dos serviços musicais, ampliou os locais de apresentações, as escolas, o comércio de instrumentos e todas as demais atividades envolvidas com a música. Para se ter uma ideia mais clara da modernidade em seu viés econômico:

\footnotetext{
${ }^{14}$ STERNE, Jonathan. The audible past: cultural origins of sound reproduction. Durham, N.C; London: Duke University Press, 2003, p. 9 [Tradução: Giuliana Lima, Juliana Pérez e Virgínia Bessa] apud PÉREZ GONZALES, Juliana. A indústria fonográfica e a música caipira gravada: uma experiência paulista (18781930). 2018. Tese (Doutorado) - Faculdade de Filosofia Letras e Ciências Humanas da Universidade de São Paulo, São Paulo.

${ }^{15}$ QUEIROZ, Suely Robles Reis de. Política e poder público na cidade de São Paulo: 1889-1954. In: PORTA, Paula (Org.). História da cidade de São Paulo: a cidade na primeira metade do século XX-1890-1954. São Paulo: Paz e Terra, 2004. v. 3, p. 17.
} 
Podemos dizer que, de 1900 a 1930, houve intensa modernização na área urbana, no sentido da adoção de novos produtos na esfera do consumo e de novas técnicas na produção industrial e na prestação de serviços. A introdução do bonde e da iluminação pública, tendo como fonte de energia a eletricidade; na indústria, a progressiva substituição do vapor pela eletricidade como força motriz; o automóvel como novo meio de transporte e também como símbolo de status social; a bicicleta, o rádio, o cinema, o gramofone, a máquina de fotografar, ainda que timidamente, foram introduzidos no cotidiano da cidade [...]. ${ }^{16}$

No período entre 1890 e 1911 (final da gestão Antônio Prado), a cidade passou por reformas no campo da urbanização, a partir dos conceitos civilizatórios europeus. Nessa lógica, a cultura consumida pelas elites teria nos recintos públicos fechados seus locais de exclusividade para a burguesia. Associações de classes também se organizaram, construindo sedes e salões onde se discutiam suas atuações e, frequentemente, ocorriam concertos e bailes para um público restrito. Mas também as ruas remodeladas, jardins e largos permaneceram nesse momento como espaços de consumo da música, porém, de forma aberta. Consequentemente, havia um universo sonoro musical acontecendo por meio de grupos que, aproveitando a iluminação das ruas, podiam, à noite, continuar o exercício da profissão ou, durante o dia, fazer uso das ruas calçadas por paralelepípedos ou macadames, bem mais confortáveis e mais limpas que as antigas ruas de terra, para despejar seus acordes.

Dentre esses grupos, as bandas povoaram a cultura, as ruas e as memórias dessa população paulistana. No entanto, com o passar do tempo, o caminho do desenvolvimento e sua modernidade tenderiam a produzir um outro olhar sobre essa cidade: o de uma cidade multifacetada, definida como de múltiplas culturas, que segundo descrição de Nicolau Sevcenko era lá pelos anos 1920:

[...] nem de negros, nem de brancos, e nem de mestiços; nem de estrangeiros, nem de brasileiros, nem americana, nem europeia, nem nativa; nem era industrial apesar do volume crescente das fábricas, nem entreposto agrícola, apesar da importância crucial do café; não era tropical, nem subtropical; não era ainda moderna, mas já não tinha mais passado $[\ldots]^{17}$

\footnotetext{
${ }^{16}$ SAES, Flávio. São Paulo republicana: vida econômica. In: PORTA, Paula (Org.). História da cidade de São Paulo: a cidade na primeira metade do século XX - 1890-1954. São Paulo: Paz e Terra, 2004. v. 3, p. 238.

${ }^{17}$ SEVCENKO, Nicolau. Orfeu extático na metrópole: São Paulo sociedade e cultura nos frementes anos 20. São Paulo: Companhia das Letras, 2003. p. 31.
} 
Naquele momento, São Paulo oferecia uma diversidade cultural sui generis, como sugere o excerto acima, ofertando novas possibilidades de espaços e motivos para apresentações, que se tornaram ao longo do tempo marca registrada não apenas da representação do poder, mas também do cotidiano dessa cidade.

Em síntese, ao se desenvolver de forma frenética, a cidade abraçou o imigrante e sua cultura, transformando a cultura paulistana preexistente em outra nova: um amálgama. Dessa forma, os imigrantes influenciaram e foram influenciados através da música, como veremos no caso do repertório das bandas de música. Gêneros que chegaram com essas culturas passaram aos poucos a fazer parte do gosto paulistano e desembarcaram nos coretos dos jardins a fim de angariar a simpatia do ouvinte e, a partir de então, tomar parte no cotidiano da trilha sonora da cidade. Assim, São Paulo já não era mais uma cidade provinciana; preparava-se para acomodar os grupos musicais que surgiam dessas transformações pelas quais a cidade passou. Iniciava-se, a partir de então, a busca e a disputa velada pelos espaços da cidade a fim de que as bandas pudessem mostrar seu trabalho, serem vistas, admiradas e aplaudidas.

\section{Os espaços na cidade ocupados pelas bandas}

À medida que a cidade se desenvolveu, a demanda por diversões públicas também seguiu o mesmo ritmo. Para acomodar essa demanda, o poder público, tomou algumas medidas em relação aos espaços da cidade, como no caso das ruas e dos Largos. Houve uma intensa movimentação a partir do último quartel do século XIX no sentido de reformar e adequar esses locais a fim de que eles pudessem receber bandas de música, companhias equestres e companhias de circo, acomodando-se não apenas os artistas, mas também o público. Por se tratar de locais públicos, porém abertos (ruas, praças, avenidas, parques, jardins), a prefeitura remodelou ruas, calçou-as, construiu recuos nos largos, e até mesmo coretos e conchas acústicas foram erguidos para atender a essa demanda cultural.

Por outro lado, outros espaços públicos, porém fechados também tiveram a mesma percepção de demanda cultural e trataram de se ajustar para absorver a clientela cujo bolso poderia pagar para assistir a uma ópera em um teatro. Divididos entre abertos e fechados, os 
espaços públicos da cidade quase sempre dividiam os expectadores mais em razão de seus bolsos que de seus gostos, como veremos.

\subsection{Espaços públicos abertos}

Grupos musicais precisam de público; afinal, traçar e manter comunicação entre aqueles e suas plateias é o objetivo principal de todo o seu trabalho artístico e, nessa São Paulo do início do século XX, esse público ocupava e se distribuía pelos espaços da cidade, conforme as possibilidades de renda.

Bairros como Lapa, Água Branca, Brás e Belém tornaram-se redutos operários, habitados por trabalhadores das indústrias que ali se instalavam, facilitando a vida destes ao evitar seu deslocamento pela cidade. Como a demanda por cultura e lazer inegavelmente cresceu, a oferta seguiu (ainda que não na mesma proporção) a tendência de acompanhar tal crescimento de demanda, atendendo a esse público. Locais como o Parque Antárctica e o Parque da Cantareira aos poucos "esticariam" o traçado da rota cultural da cidade, oferecendo maiores opções de cultura e lazer. Por outro lado, os locais privados passaram a ter, a partir de então, maior possibilidade de oferecer conforto a seus frequentadores, que assistiam a um concerto em algum teatro no centro da cidade, por exemplo, mais como um evento social em que precisavam ser vistos do que propriamente como um espetáculo. Nesse sentido, a reurbanização do centro, a melhora na iluminação das ruas, seus calçamentos, a inauguração do Teatro Municipal em 1911, outras inaugurações de confeitarias, bares, cafés - e até mesmo, o movimento anarco-sindicalista erguendo sedes de clubes operários - foram fatores que contribuíram para a sedimentação dos espaços de atuação dos grupos musicais na cidade. Nesse universo, as acomodações ocorreram de acordo com as forças políticas, econômicas e culturais, tensões geradas dentro da esfera do poder e da música, esfera esta em que orquestras tinham seu espaço específico, bandas outro, e os demais grupos menores também outro, o qual não era nem o espaço da orquestra nem o da banda.

De modo geral, as bandas possuíam por espaço as ruas e coretos de jardim (público aberto) enquanto as orquestras ocupavam os espaços de elite da cidade - os palcos dos teatros (público fechado). Dentro dessa demarcação social, os espaços públicos abertos na cidade, nos quais as bandas tocavam estavam, até o final do século XIX, muito bem definidos e divididos de forma equânime entre as bandas do $10^{\circ}$ Regimento de Cavalaria do Exército 
Brasileiro e a da Força Policial. Relegavam-se às outras bandas os lugares mais distantes do triângulo central da cidade e, consequentemente, de menor importância como por exemplo o Largo da Concórdia no Brás.

No entanto, a partir do início do século XX, isso tenderia a mudar. Para se ter uma ideia de como as bandas militares cercavam e eram cercadas pelo poder, são apontados, no mapa a seguir (Figura 1), o Jardim do Palácio (atual Pátio do Colégio), onde ficava o Palácio do Governo do estado e suas principais secretarias, e o Jardim da Luz. Ambos eram locais privilegiados de apresentação dessas bandas até o início do século XX. Como exemplo dessa afirmação, na edição de domingo, 8 de novembro de 1903 do Correio Paulistano, suas colunas "Factos Diversos," "Annuncios" e "Notas E Factos" traziam apresentações de bandas de música no Jardim da Luz, Jardim do Palácio, Parque da Cantareira, Largo da Concórdia, Frontão Boa Vista e Coreto do Lyceu dos Salesianos, além de peças teatrais e musicais em diversos teatros da cidade. ${ }^{18}$

Locais como o Jardim do Palácio tornaram-se, após a República, assiduamente frequentados pela Banda do $10^{\circ}$ Regimento de Cavalaria do Exército e pela Banda da Força Policial, quer esta estivesse dividida em seções quer completa. ${ }^{19}$ No entanto, em raríssimas vezes, bandas civis como a da sociedade Ettore Fieramosca ${ }^{20}$ se faziam presentes nesse seleto e cobiçado espaço de poder. Em sua obra Alguns dias na Paulicéia, Henrique Raffard nos fornece uma boa visão da dinâmica desse espaço, narrando que a música dos Permanentes tocava das sete às nove horas no Jardim do Palácio, regularmente todas as quintas-feiras e domingos. Além destes dias, ainda era possível apreciar o grupo de vez em quando em outras oportunidades. $^{21}$

\footnotetext{
${ }^{18}$ Factos diversos. Correio Paulistano, São Paulo, p. 2, 3, 5, 8 nov. 1903. Para Jardim da Luz: uma seção da Banda da Força Policial (p. 2). Para Jardim do Palácio: uma seção da Banda da Força Policial (p. 2). Para Parque da Cantareira: Música no Parque, banda não identificada (p. 2). Para Largo da Concórdia, Música no Coreto, com banda não identificada (p. 2). Para Salesianos, Lyceu dos Salesianos, Coreto interno dos Salesianos pela banda do estabelecimento (p. 3). Para Frontão Boa Vista, Attrahentíssima Funcção Sportiva, banda não identificada (p. 5).

${ }^{19}$ A partir de 1895, a Banda da Força Pública passa a se apresentar dividida em duas seções ou, quando é o caso, completa.

${ }^{20}$ Divertimentos de hoje. Jardim do Palácio. Correio Paulistano, São Paulo, p. 4, 20 dez. 1903.

${ }^{21}$ RAFFARD, Henrique. Alguns dias na Paulicéia. São Paulo: Academia Paulista de Letras, 1977. p. 21.
} 


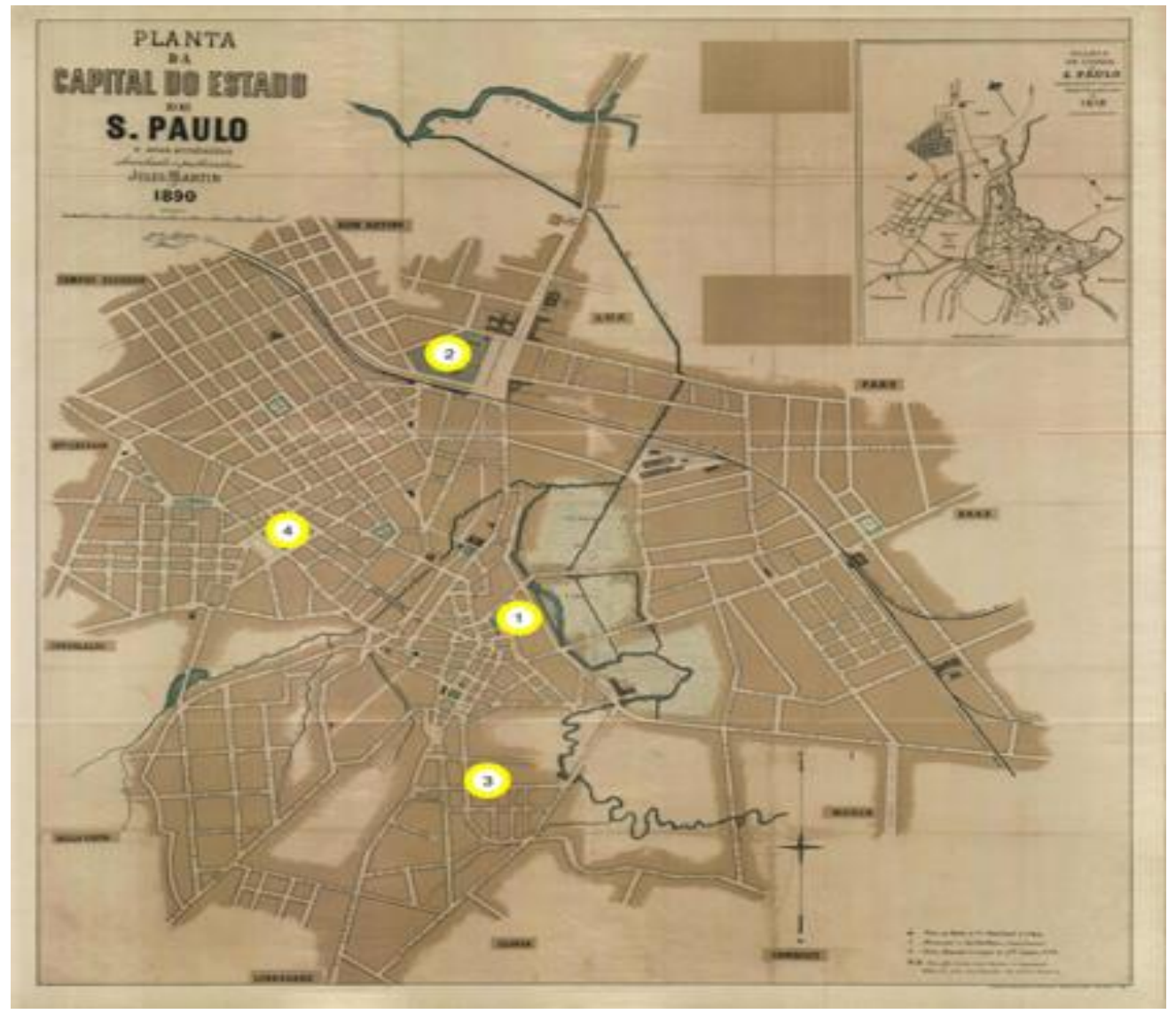

Figura 1. Mapa do centro da cidade de São Paulo $1890 .{ }^{22}$

Nota: Observa-se ao centro o Jardim do Palácio (1). Também ao centro, o Jardim Público (Jardim da Luz) (2), o Jardim da Glória (3) e a Praça da República (4). É importante ressaltar que quase toda a produção musical ainda se concentrava na região do chamado triângulo central da cidade, delimitado pelas atuais ruas 15 de novembro, São Bento e Direita.

Pela proximidade da administração pública, o Jardim do Palácio era marcado por uma certa aura, devido à qual os grupos que nele se apresentavam faziam-no de forma a corroborar a suntuosidade do local, local esse que revela, de certa forma, essa efervescência cultural que aos poucos se consolidou na cidade a partir do advento da República. Em suas memórias, Jorge Americano descreve o Jardim do Palácio como:

O Pátio do Colégio constituía o Jardim do Palácio, cercado de grades, com dois portões abertos. No lugar de onde parte o viaduto Boa Vista, ficava o coreto, em forma de concha acústica voltada para o jardim. Na curva que desce para a ladeira General Carneiro (então chamada João Alfredo), estava a fonte, onde uma estátua de mulher, feita de cimento, despejava o cântaro, sobre o laguinho de cimento.

22 SÃO PAUlO (Cidade). Mapa do centro da cidade de São Paulo, 1897. Disponível em: <http://www.prefeitura.sp.gov.br/cidade/secretarias/cultura/arquivo_historico/arquivo_historico/index.php?p= 22255>. Acesso em: 20 mar. 2018. 
Terminado o jantar, às cinco, as famílias dos bairros vinham vindo. Sentavam nos bancos do jardim. Os vadios eram escorraçados e ficavam para o lado de fora das grades.

Ouvia-se um toque de marcha e chegava a banda regida pelo maestro Antão Fernandes $[\ldots]^{23}$

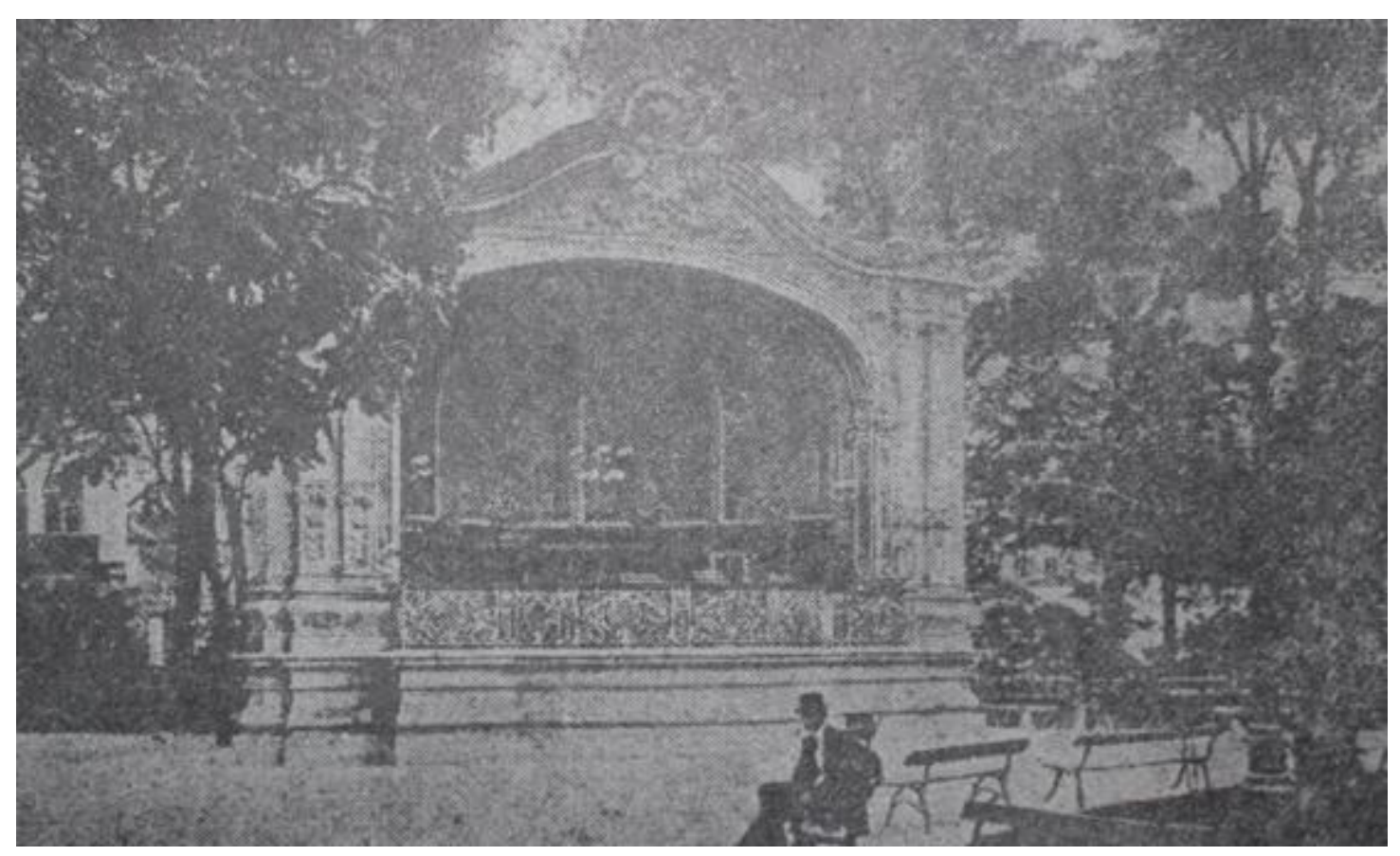

Figura 2. Jardim do Palácio - Coreto.

Nota: Palco construído durante a gestão de Campos Salles (1896-1897) com o intuito de abrigar as bandas de música durante suas apresentações.

Fotografia extraída de DELLA MÔNICA. ${ }^{24}$

De acordo com Solange Ferraz Lima, ${ }^{25}$ o Jardim do Palácio representava o espaço de gerência da cidade pelo Estado, além de guardar também as funções religiosas. O investimento feito pelo poder público na construção do coreto revelava as intenções de aproximação e união entre esse poder e as bandas. A concha acústica, construída com a finalidade de abrigar bandas de música (Figura 2), demonstrava claramente a influência sobre e a importância desses grupos para a política. Seu palco, de grande profundidade, apresentava a possibilidade de acolher grandes grupos, como as bandas da Força Pública (fiel e assídua

\footnotetext{
${ }^{23}$ AMERICANO, Jorge. São Paulo naquele tempo -1895-1915. 2. ed. São Paulo: Carrenho Editorial, Narrativa Um, Carbono 14, 2004, p. 191.

${ }^{24}$ DELla MONICA, Laura. História da Banda de Música da Polícia Militar do Estado de São Paulo. 2. ed. São Paulo: Edanee, 1975. p. 45.

${ }^{25}$ LIMA, Solange Ferraz. Pátio do Colégio, Largo do Palácio. In: Anais do Museu Paulista, São Paulo, v. 6-7, n. 1, p. 61-82, 1999.
} 
frequentadora), capaz de compor conjuntos com aproximadamente 70 figuras quando completa. Curiosidade do documento acima é o fato de não se observarem bancos nem cadeiras para acomodação dos músicos; havia apenas estantes, o que revela que possivelmente, mesmo em local parado e coberto, a postura dos músicos na execução dos concertos ou retretas era ainda em pé.

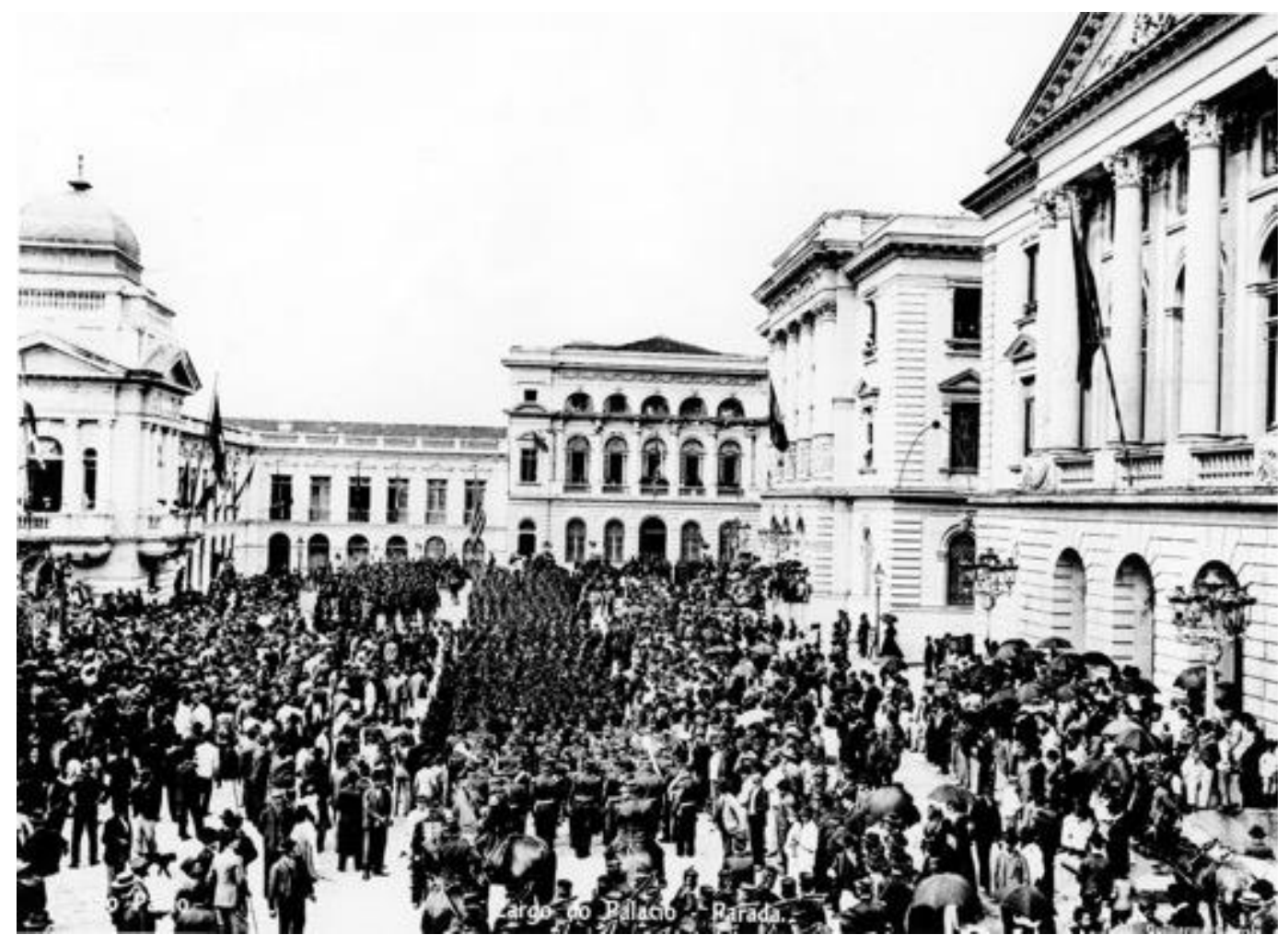

Figura 3. Largo (ou Jardim) do Palácio - Parada - 1905 ou 1906.

Fotografia extraída de Gaensly (1988). ${ }^{26}$

A imagem acima (Figura 3) traz uma vista panorâmica do Jardim do Palácio durante uma parada militar em data comemorativa, possivelmente nos anos de 1905 ou 1906. Reforçando o simbolismo de poder, os prédios que compõem o referido espaço - da esquerda para a direita, Palácio do Governo, Secretaria do Interior e da Justiça, Polícia Central e Secretaria da Agricultura e da Fazenda - são assinados pelo arquiteto Ramos de Azevedo. Em uma leitura um pouco mais apurada, pode-se perceber o movimento das tropas no sentido

${ }^{26}$ GAENSLY, Guilherme. São Paulo 1900. São Paulo: Livraria Kosmos Editora, 1988. p. 24-25. Imagens de Guilherme Gaensly. Análise e interpretação de Boris Kossoy. 
Secretaria da Fazenda para o Palácio do Governo (local geralmente destinado à montagem de palanques para o recebimento das continências e honras militares por parte dos que desfilam), bem como a participação popular no evento, cercando lateralmente as tropas e a Banda de Música da Força Pública. Cabe ressaltar ainda que há certa interação do público no evento como parte ativa, ao contrário do que viria a acontecer após a chegada da era Vargas e até os dias atuais em que o público exerce papel de expectador apenas, conforme nos aponta Roberto DaMatta. ${ }^{27}$

O Jardim do Palácio continuaria a ser um dos principais espaços representativos do poder, sendo cortejado por diversos grupos musicais de São Paulo até a mudança da sede do governo paulista para o Palacete Elias Chaves em 1912, no bairro dos Campos Elíseos, quando se encerra esse ciclo. A partir da década de 1920, tornar-se-ia aos poucos uma área de circulação, depois estacionamento para automóveis, até a demolição do Palácio em 1953.

Outra referência espacial para as bandas, sem dúvida, foi o Jardim Botânico chamado também de Passeio Público, Jardim Público e, finalmente, Jardim da Luz ${ }^{28}$ (espaço mais acessível ao público no início do século $\mathrm{XX}$ ) -, onde se desenvolveu a grande parte das apresentações de todas essas corporações, trazendo à população boa parte da cultura disponível na cidade (ainda que subvencionada pelo Estado no caso das bandas militares). Criado como Jardim Botânico, o Jardim da Luz teve sua construção iniciada em 1799 e foi entregue ao público só em $1825,{ }^{29}$ constituindo-se em um dos principais pontos de lazer da população ao longo do século XIX e metade do XX. Lugar de exercício da sociabilidade, registra a frequência de muitas famílias, incluindo membros do poder público; a ocupação desse espaço, no entanto, não era tão exclusiva das bandas militares, conforme nos aponta novamente Raffard:

Os bons músicos do Corpo Policial de Permanentes se podem ainda apreciar no Passeio Público para onde corre muita gente nas quintas e domingos das 3 às 6 horas da tarde como antigamente.

Além de outras bandas civis e militares, há uma formada de artistas italianos, na maior parte alfaiates, que nos dias festivos passeiam com a farda dos Bersaglieri. ${ }^{30}$

\footnotetext{
${ }^{27}$ DAMATTA, Roberto. Carnavais, paradas e procissões. In: DAMATTA, Roberto. Carnavais, malandros e heróis: para uma sociologia do dilema brasileiro. 6. ed. Rio de Janeiro: Rocco, 1997.

${ }^{28}$ Nomes pelos quais o Jardim da Luz foi chamado desde sua criação em 1799.

${ }^{29}$ MARTINS, Antônio Eggydio. São Paulo Antigo - 1554 a 1910. São Paulo: Paz e Terra. 2003. v. 1.

${ }^{30}$ RAFFARD, Henrique. Alguns dias na Paulicéia. São Paulo: Academia Paulista de Letras. 1977. p. 21
} 
Após 1893, o Jardim Público (depois Jardim da Luz) passou a ser administrado pela Prefeitura e, na gestão do prefeito Antônio Prado (1899-1911), ganhou uma grande reforma e remodelação, passando até mesmo a possuir um viveiro de mudas de árvores, as quais eram fornecidas ao restante da cidade. Dessa forma, criava-se um espaço concebido nos moldes dos grandes e belos jardins europeus, o qual propiciava um requinte à sociabilidade urbana da elite. Isso trouxe personalidades dessa classe social paulistana, como o próprio prefeito e sua família, a frequentá-lo quando dos concertos das bandas de música. ${ }^{31}$ Um projeto de construção de uma nova hospedaria de imigrantes rondou as mentes da sociedade promotora da imigração nas décadas finais do século XIX, no qual se pensou utilizar o espaço do Jardim para acomodação da mão de obra que chegava a São Paulo, descaracterizando socioeconomicamente, dessa forma, não apenas o Jardim, mas o bairro todo da Luz, como área nobre de convívio, conforme descreve Odair Paiva:

A construção de uma nova hospedaria [de imigrantes] tornava-se indispensável. Com a abertura da concorrência em 1886, a comissão incumbida de escolher o terreno para a construção da obra tinha duas opções: um terreno ao lado da estrada de ferro São Paulo Railway e o terreno do convento da Luz, no bairro do mesmo nome que fora desapropriado pelo Governo Provincial. Venceu o argumento de que o bairro da Luz não se prestava a ser um alojamento de imigrantes, mas de que ele deveria ser "aformoseado", uma vez que para lá acorria a população mais abastada da cidade. No seu entorno já se construíam os palacetes do bairro dos Campos Elíseos. ${ }^{32}$

Presença comum, pelo menos, todas as quintas e domingos no coreto do Jardim da Luz, conforme apontado, as bandas viam naquele espaço a possibilidade de acomodar um grande número de pessoas que para ali afluíam, quer nesses dias e horários marcados, quer em festas especiais ou feriados, quando o público aumentava. Para as bandas, outro ponto favorável do local era o fato do Jardim conseguir acomodar mais de uma banda tocando no mesmo evento, o que dava a grupos distintos a oportunidade de travarem contatos pessoais, mostrarem seus trabalhos uns aos outros, colaborarem para a melhoria técnica nas performances de determinados repertórios, assistindo-se e ouvindo-se mutuamente, o que

\footnotetext{
${ }^{31}$ SEGAWA, Hugo. Ao amor do público: jardins do Brasil. São Paulo: Studio Nobel, 1996. p. 136.

32 PAIVA, Odair da Cruz. Histórias da (I)migração: imigrantes e migrantes em São Paulo entre o final do século XIX e o início do século XXI. São Paulo: Arquivo Público do Estado, 2003. p. 61.
} 
gerava inclusive a possibilidade de fazer intercâmbio de repertórios, algumas vezes até de músicos ou, até mesmo, de competir entre si em concursos realizados pelas mais diversas entidades.

Circundado pela estação da Luz, e tendo como vizinhos a Escola Politécnica, o Quartel da Luz da Força Pública e o Convento da Luz, além do Seminário Episcopal, o Jardim permaneceu até o final do segundo decênio do século XX como ponto central da cultura e palco principal das apresentações das bandas de música na cidade de São Paulo. No entanto, a partir dos anos 1920 o consequente crescimento da cidade, que impôs necessidades antes inexistentes promovidas em parte por sua reurbanização, o Jardim aos poucos cairia no silêncio: suas apresentações se reduziriam e haveria esvaziamento do público, que migraria do convívio social coletivo para o individual devido à mudança dos circuitos do som, que sairia do ambiente público e iria para o privado.

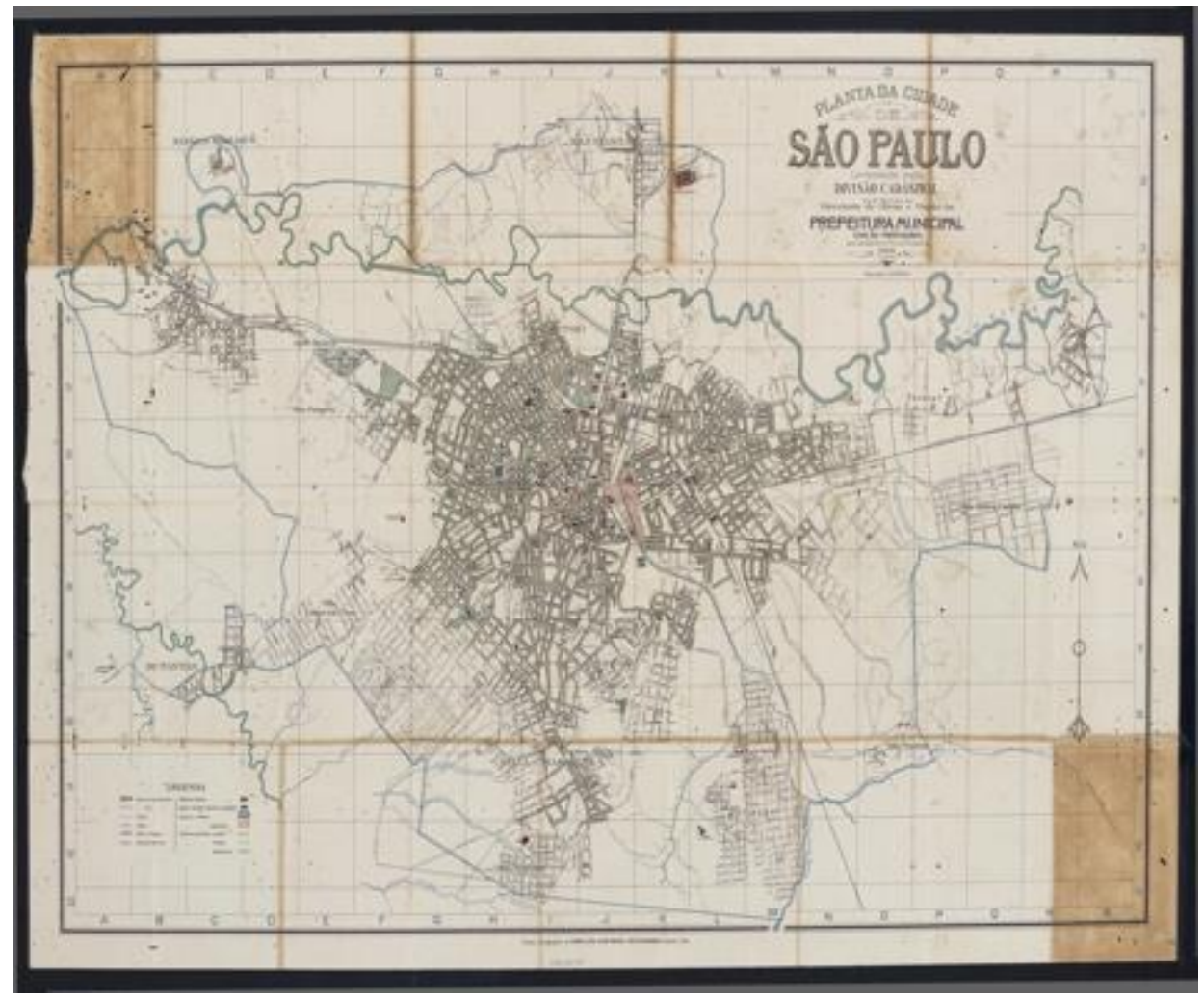

Figura 4. Mapa do centro da cidade de São Paulo 1916. ${ }^{33}$

Nota: Percebe-se uma expansão da zona musical, que caminha no sentido do centro (Triângulo) para a periferia da cidade, em especial as zonas Norte, Leste e Oeste.

33 SÃO PAULO (Cidade). Mapa do centro da cidade de São Paulo, 1905. Disponível em: $<$ http://www.prefeitura.sp.gov.br/cidade/secretarias/cultura/arquivo_historico/arquivo_historico/index.php?p= 22255 >. Acesso em: 20 mar. 2018. 
O Jardim da Luz, que antes dividia a participação das melhores bandas com o Jardim do Palácio, passou a enfrentar a concorrência dos coretos do Largo da Concórdia (Brás), do Parque Antarctica (Água Branca) e do Parque da Cantareira (zona Norte). Em dias de concertos, por exemplo, bondes especiais seguiam para esses locais para facilitar a movimentação da população. Aos poucos, as bandas também começaram a se movimentar pela cidade, que agora era ligada por um sistema de transporte público com bondes elétricos e tramways, o que facilitava seu deslocamento, já que gastavam menos tempo entre um bairro e outro, o que resultava em maior agilidade na prestação dos serviços. Graças às reformas urbanas, o alargamento das ruas e esse sistema de transporte, os locais acima descritos passaram a ser frequentados pelas bandas, sobretudo durante os finais de semana, locais esses nos quais a população começava a buscar cultura e lazer. Parques como o Antárctica e o Cantareira não mais representavam distâncias inatingíveis e passavam a receber um público oriundo tanto do centro da cidade, que poderia se deslocar com bondes de hora em hora, quanto de residentes dos subúrbios, geralmente operários das fábricas que ali se instalavam nesse momento.

É possível, dessa forma, interpretar que as bandas cumpriam aqui um sutil papel de apoio ao poder público no sentido de dignificar ou convalidar esses novos espaços, que se criavam pela expansão do centro, à medida que este se elitizava no início do século XX, e de legitimar a ocupação da periferia, como bairros de operários também com o direito à cultura e ao lazer. O desenvolvimento da cidade e sua expansão seriam acompanhados pelas bandas, como promotoras sonoras das grandes inaugurações, que alterariam os traçados urbanos. Assim, as bandas modificariam o cotidiano da cidade, influenciando seus espaços de lazer.

Ainda no campo público, as ruas representaram mais que um espaço democrático ideal para esses grupos musicais, onde se socializavam o som e a cultura. Elas se tornaram o grande palco onde as bandas desenvolveram suas apresentações. É certo que determinadas festas ocorriam em recintos públicos fechados (clubes, igrejas, associações, etc.), porém, nesse momento e durante muito tempo, era das ruas, avenidas recém-construídas ou dos coretos dos largos e jardins que o som brotava, ${ }^{34}$ pois esse era o espaço natural para grupos de amplitude tão grande quanto as bandas. Havia uma ocupação sonora desse espaço por meio das alvoradas nas datas cíclicas e festas cívicas ou militares. Em suas memórias, Jorge

\footnotetext{
${ }^{34}$ Cf. TINHORÃO, José Ramos. Os sons que vêm da rua. 2. ed. São Paulo: Editora 34, 2005.
} 
Americano cita com entusiasmo a lembrança de um desfile da Banda da Força Policial retornando da campanha de $\operatorname{Canudos}^{35}$ e anunciando à cidade a vitória republicana sobre Antônio Conselheiro. À época, havia uma incrível dinâmica de bandas acompanhando e sonorizando os inúmeros acontecimentos culturais pelas ruas da cidade. Elas estavam sempre presentes, por exemplo, nas corridas de touro. ${ }^{36}$ Esses eventos eram comuns durante o último quartel do século XIX e o início do XX. As corridas mais famosas eram disputadas no antigo Largo dos Curros (Praça da República), sempre com a presença de bandas de música para animar o espetáculo e perduraram até sua primeira grande reforma no início do século XX, quando a Praça, ganhando ares europeus, pontes e canteiros, deixou de atrair os espetáculos das touradas e suas corridas, passando a atrair as famílias das vizinhanças em outros acontecimentos, como o das prévias de carnaval, por exemplo.

Outros eventos importantes foram os desfiles (ou paradas) nos prados da Mooca. Eram cerimônias ou espetáculos de aprimorada técnica de caráter militar e conteúdo cívico, durante os quais a Força Pública apresentava-se em desfiles para comemorar o aniversário da República, sempre em 15 de novembro, entre os anos de 1906 e 1927, contando com sua banda de música, regida pelos maestros Lorena e Antão Fernandes ${ }^{37}$ Em suas memórias, Jorge Americano ${ }^{38}$ relata que o início se dava às 10 horas, quando o Presidente do Estado chegava. Herança da primeira missão francesa (1906-1914), tratava-se, na verdade, de um grande e complexo exercício de adestramento da milícia, porém com o caráter de exibir a força da Força. Sentia-se a cumplicidade entre a Banda e o poder, uma vez que, ao chegar ao local, ouvia-se o toque de presença, exórdio e marcha batida (continência para o Presidente do Estado devidamente executados pela banda de música). Após a devida honra, este passava em revista à tropa e autorizava o desfile e demonstrações, incluindo o Carrossel (um balé equestre protagonizado pelo regimento de cavalaria), durante o qual a banda também exercia importante função na trilha sonora do espetáculo. ${ }^{39}$

\footnotetext{
${ }^{35}$ AMERICANO, Jorge. São Paulo naquele tempo - 1895-1915. 2. ed. São Paulo: Carrenho Editorial, Narrativa Um, Carbono 14, 2004. p. 191

${ }^{36}$ Grande Praça de Touros. O Correio Paulistano, São Paulo, 19 jan. 1902. Annuncios, p. 3.

${ }^{37}$ FERRAZ, Cel. Arrisom de Souza. As paradas da Força Pública nos prados da Moóca. Revista do Arquivo Público Municipal, São Paulo, v. CLXII, p. 383-390, jan.-mar. 1959.

${ }^{38}$ AMERICANO, Jorge. São Paulo naquele tempo -1895-1915. 2. ed. São Paulo: Carrenho Editorial, Narrativa Um, Carbono 14, 2004. p. 362-363.

${ }^{39} \mathrm{O}$ Carrossel ainda é encenado uma vez por ano, sempre em outubro, na semana das comemorações de aniversário de fundação do Regimento de Cavalaria 9 de Julho, com a participação de um esquadrão de cavalaria
} 
Em geral, nos torneios esportivos, era também imprescindível a presença das bandas. Partidas de futebol ${ }^{40}$ e outros esportes, como torneios de esgrima, ${ }^{41}$ baseball e campeonatos em clubes de tiros, realizados em diversos lugares da cidade, começaram a se popularizar e ganhar público, também a partir do último quartel do século XIX. Para os "matchs de football", previa-se a inclusão de uma apresentação de bandas de música no início ou nos intervalos dos espetáculos a fim de animar as torcidas. O mesmo ocorria em outros esportes, que contavam com as bandas para os intervalos entre uma partida e outra, um tempo e outro, ou simplesmente para dar ao evento uma impressão de poder, requinte e alegria. No caso dos clubes de tiros, além de abrilhantar competições tocando o Hino Nacional em sua abertura e encerramento, as bandas os acompanhavam quando desfilavam em comemoração ao 7 de setembro ou 15 de novembro. Em 1910, por exemplo, dois pelotões do Clube de Tiro Brasileiro no 34 - Linha General Pedroso da Cidade de São Paulo seguiram com destino ao Rio de Janeiro, a fim de desfilar na comemoração da independência, acompanhados por uma das seções da Banda de Música da Força Pública, tendo à frente o alferes Lorena como maestro. ${ }^{42}$ É importante salientar que o registro da criação da Banda de Música desse clube de tiro, composta por seus associados, trazia à frente o maestro $2^{\circ}$ tenente Antônio Galluzzio. Lorena apenas exerceu as funções de "fiscal” dos trabalhos para os desfiles no Rio de Janeiro em 7 de setembro daquele ano de 1910.

As estações de trem quase sempre se transformaram também em "palcos abertos" de apresentações das bandas, anunciando chegadas e partidas. Com a inauguração, em 1867, da linha férrea entre Santos e São Paulo pela São Paulo Railway Company (linha essa que, em uma segunda e posterior etapa, chegaria até Jundiaí), a cidade começava a abrir as comunicações, de forma mais rápida, com o porto, interior e, aos poucos, com o Oeste paulista (fato que se consolidaria no primeiro decênio do século XX). Portas de entrada para a cidade, as estações ferroviárias ganharam grande importância não apenas pela real função que passaram a ter no sistema de transporte e comunicação, mas também por seu simbolismo. A economia do café deixava os lombos das tropas de muares, para muito mais rapidamente

\footnotetext{
e a Banda de Música da Força Pública. Sobre as paradas nos Prados da Mooca, retornaremos ao assunto no capítulo 3 quando discorrermos sobre a referida Banda.

${ }^{40}$ Sport. O Estado de São Paulo, São Paulo, p. 2, 11 jun. 1903.

${ }^{41}$ Sport. O Estado de São Paulo, São Paulo, p. 2, 23 nov. 1903.

${ }^{42}$ Sport. O Estado de São Paulo, São Paulo, p. 6, 19 jul. 1910.
} 
escoar sua produção pelos trilhos, passando pelos armazéns das estações; pessoas ilustres e anônimas passaram a cruzar fronteiras sociais, econômicas e culturais ao descerem dos trens, deixando para trás o sertão com seus pés de café, afluindo das gares para ganhar as ruas da cidade.

Durante os anos que vão entre 1870 e 1930, as três maiores estações existentes em São Paulo foram a Estação da Luz (inaugurada, em 1867, em um primeiro projeto que passaria por três reformas até a atual arquitetura), a da linha Sorocabana, Júlio Prestes (inaugurada em 1872), e posteriormente, a do Norte (inaugurada em 1875). Ali, em suas plataformas de embarque ou desembarque, o ritual da representação do poder e do prestígio social, econômico e político atingia pontos importantíssimos e simbólicos com as bandas de música. Saudações de grandes personagens (sobretudo políticos) em suas chegadas à cidade de São Paulo - pelas estações do Norte, oriundos geralmente da capital federal ou do Vale do Paraíba, pela Inglesa (Luz), vindos de Santos, e posteriormente, pela Sorocabana, chegados do interior do estado - eram produzidas com grandes aglomerações para onde, dependendo da autoridade a ser recepcionada, o público afluía para tomar parte no ritual que se tornava um evento social. No entanto, é necessário enfatizar-se que tais rituais desencadeados quase diariamente, ocorriam dentro de um pequeno e seleto círculo de poder. Os rituais cumpriam o papel de personificação e anúncio desse poder e prestígio. Misturado às chegadas e partidas de grandes personalidades, ao público comum restava apreciar o espetáculo proporcionado pela multidão que se aglomerava nas plataformas e a apresentação das bandas que se faziam presentes, transformando tudo em uma grande festa popular a que todos passavam a ter direito de usufruir.

Outros locais públicos em que era possível ouvir os acordes das bandas eram as sedes dos poderes. A do poder executivo (Palácio do Governo), a do Senado do Congresso Legislativo e a da Câmara do Congresso Legislativo do Estado, que funcionaram entre 1891 e 1930, e a do Tribunal de Justiça do Estado. Nessas sedes, ocorriam rituais de representação de poder. Pela proximidade dessa representação, as bandas de música militares (Força Pública, Exército Brasileiro e Guarda Nacional) eram parte integrante dos rituais de abertura dos anos legislativos, das recepções a autoridades estrangeiras que visitavam a cidade e suas respectivas sedes dos poderes, pois, afinal, essas bandas também funcionavam, na verdade, como extensão dos executivos (estadual ou federal). As bandas eram convidadas a abrilhantar 
encerramentos de legislaturas, festas e feriados nacionais e até mesmo sessões ordinárias em comemoração aos mais diversos motivos. O interior desses prédios públicos, como o Senado estadual, a Câmara dos Deputados e também o próprio Palácio do Governo, além dos mesmos níveis políticos na esfera do município, também eram lugares comuns para as bandas, sobretudo para as da Força Pública. ${ }^{43}$

\subsection{As festas}

Durante a Primeira República, não faltavam eventos de rua. Em uma cidade em rápido crescimento, as inaugurações dos mais diversos tipos eram muito comuns e em muitas delas apresentavam-se bandas, como forma de atrair o público, como ocorrera na instalação da Companhia Cervejaria Bavária na Mooca, de uma roda-gigante na Alameda Barão de Limeira, ${ }^{44}$ ou mesmo de um açougue, o que revela que, para que houvesse um perfeito rito de inauguração para qualquer casa, havia também a necessidade de ter-se presente uma banda; caso contrário o rito não se completava. As inaugurações de prédios públicos também eram oportunidades de propaganda política e demonstração da modernidade, geralmente acompanhadas pelas bandas. Festas para inaugurar tais prédios, assim como asilos, hospitais, estradas de ferro ou trechos destas, iluminação, monumentos ou estátuas (memórias do poder) e, claro, marcos históricos como a avenida Paulista em 1891, tornaram-se comuns no período. Em 1892, as aberturas do Viaduto do Chá e, em 1911, do Teatro Municipal, tornaram-se ainda mais memoráveis graças a essas ferramentas sonoras. Na inauguração do Viaduto do Chá, em 1892, o Estado de São Paulo informou que diversas bandas de música deveriam percorrer várias ruas mencionadas no programa de festejos, prestando, assim, seu valioso concurso a essa cerimônia. ${ }^{45}$

O carnaval, festa popular que tomava as ruas da cidade no começo de cada ano, contava com as bandas para arrastar os foliões e sonorizar o reinado de momo. Claro que havia os carnavais de salão em recintos fechados, mas a diversão estava mesmo em ambiente aberto, como apontam os memorialistas. Puxar os desfiles dos blocos ou do corso

\footnotetext{
${ }^{43}$ Ainda hoje é muito comum a presença da banda de música da Polícia Militar do Estado de São Paulo em sessões solenes na Câmara Municipal de São Paulo e na Assembleia Legislativa do Estado de São Paulo, executando as devidas continências para o presidente da casa, além do Hino Nacional Brasileiro em Si Bemol maior para continência e marcar a abertura dos trabalhos.

${ }^{44}$ Notícias diversas. O Estado de São Paulo, São Paulo, p. 2, 28 set. 1902.

${ }^{45}$ Viaducto do Chá. O Estado de São Paulo, São Paulo, p. 1, 6 nov. 1892.
} 
carnavalesco não era tarefa das mais fáceis. As bandas precisavam ter uma boa composição (em tamanho e instrumentação) para se fazerem ouvir em meio à multidão.

Vale lembrar que o carnaval possuía um único significado para o músico: trabalho. Esse era o momento de ganhar alguma verba extra a fim de conseguir se sustentar até o final do período da quaresma, que terminada no sábado de aleluia, reabria a temporada de festas cíclicas, quando então os bailes voltavam a acontecer, e as bandas passavam a ser novamente solicitadas, reiniciando-se assim a temporada de ganhos para os músicos. Clubes como Os Tenentes de Plutão, Feniano e Os Democráticos organizavam préstitos, contando indispensavelmente com a participação de bandas de música, cujas verbas para seu pagamento poderiam ser públicas (nem sempre atendidas) ou, como era mais comum, particulares. ${ }^{46}$ Durante o período carnavalesco, era comum as bandas tocarem em determinados pontos nas ruas, estacionadas ou mesmo em desfile. Apresentações em praças (Largos) para alegrar a cidade também ocorriam. Em suas memórias, Jorge Americano relata os antecedentes do carnaval na Praça da República:

Ali por 1902 a Praça da República foi cercada de arame farpado. Vieram carroças, removeu-se terra daqui para ali, fizeram o lago, plantaram árvores, gramaram canteiros, e numa tarde de Ano Bom, com banda de música, foi inaugurado o jardim, com a Presença do Presidente do Estado e do Prefeito. Ajardinada, a Praça da República, ao cair da noite, depois do jantar, tornouse ponto de reunião das famílias dos Campos Elísios, Vila Buarque e Higienópolis.

Mais tarde (1910 mais ou menos) criou-se o hábito dos sábados Pré carnavalescos, que começavam no Ano Bom e terminavam no último sábado antes do Carnaval. ${ }^{47}$

Outras narrativas revelam que o carnaval na São Paulo dos anos 1910-1930 era uma festa animada e que as ruas ficavam repletas de automóveis, produzindo corsos pelas avenidas (incluindo a Paulista), onde as batalhas de confetes, serpentinas e lança-perfumes desenvolviam-se de modo muito alegre, ${ }^{48}$ animadas por charangas (pequenas bandas musicais arregimentadas para essa finalidade). Aqui, pode-se ter a real percepção de que o

\footnotetext{
${ }^{46}$ Ata da $4{ }^{\text {a }}$ Sessão Ordinária da Câmara Municipal de São Paulo datada de 26 jan. 1909. PAR-CJ 11 e CF 09 Indeferindo petição do presidente da Sociedade Club dos Democráticos Carnavalescos, solicita auxílio para exibir um préstito nas ruas da cidade. PAR-CJ 12 e CF 10 sobre petição do presidente do Club Fenianos Carnavalescos solicita auxílio para os festejos do carnaval. Fls. 13 a 19.

${ }^{47}$ AMERICANO, Jorge. São Paulo nesse tempo (1915-1935). São Paulo: Melhoramentos, 1962. p. 117

${ }^{48}$ FAUSTO, Boris. Negócios e ócios: histórias da imigração. São Paulo: Companhia das Letras, 1997.
} 
som do carnaval vinha das ruas. Porém, os ambientes dividiam-se como sempre entre o público fechado e aberto. Fechado, nos bailes para atender a uma determinada elite que fazia parte daquele círculo de poder ao qual as bandas já estavam acostumadas, e aberto, onde todos tinham a liberdade de ouvir, cantar, brincar e misturar-se entre as classes, sem a preocupação do preconceito, ainda que apenas em uma brincadeira de quatro dias.

Ainda no espaço público aberto, farta documentação reporta a execução de um tipo de desfile com características diferenciadas, chamado de Marche aux Flambeaux. Na verdade, tratava-se de uma procissão (não necessariamente religiosa), muito utilizada pela Força Pública, realizada sempre à noite pelas principais ruas da cidade, quando as bandas tocavam e os participantes conduziam lanternas acesas ou tochas nas pontas de bastões, produzindo efeito deslumbrante.

Outro importante motivo para reuniões sociais, como parte desse universo das ruas, eram as festas religiosas, que, como apontado anteriormente, ocorriam ciclicamente. Ano a ano, as comemorações tomavam corpo e realizavam-se sob a responsabilidade de uma determinada sociedade, irmandade ou comissão de festeiros. Algumas dessas festas tornaram-se muito conhecidas durante os anos da Primeira República e, mesmo tendo suas origens em tempos mais remotos, passaram pelo período da Primeira República incólumes, existindo até hoje.

A festa de Santa Cruz do Pocinho era comemorada anualmente em 3 de maio, na capelinha do mesmo nome, situada na rua Vieira de Carvalho. O nome da capela era decorrente de uma lenda. Teria sido erigida sobre os entulhos de um poço (daí Pocinho), onde um funcionário (poceiro) encarregado de sua limpeza havia morrido. A festa era muito frequentada por gente de todos os bairros da cidade, tendo chegado a ocupar com multidões o trecho que vai da Praça da República ao Largo do Arouche. ${ }^{49}$ A partir de 1908, a festa de Santa Cruz do Pocinho (sempre com a participação de bandas de música) deixou de ser celebrada por ordem das autoridades religiosas, especificamente D. Duarte Leopoldo e Silva, então Bispo de São Paulo. ${ }^{50}$

\footnotetext{
${ }^{49}$ BRUNO, Ernani Silva. História e tradições da cidade de São Paulo. Rio de Janeiro: José Olympio Editora, 1954. v. III., p. 1225.

${ }^{50}$ BRUNO, Ernani Silva. História e tradições da cidade de São Paulo. Rio de Janeiro: José Olympio Editora, 1954. v. III., p. 911.
} 
Outra festa, a de Nossa Senhora da Penha, era realizada anualmente, a cada 8 de setembro, sempre contemplada por bandas de música, reunindo muitas pessoas. $\mathrm{O}$ mesmo memorialista faz menção a ela até o ano de 1903 sendo celebrada no centro da cidade. ${ }^{51}$ Contudo, outras fontes e a grande imprensa confirmam sua existência em anos posteriores no bairro do mesmo nome, guardando as mesmas datas e contando com a participação de orquestras e coros sacros para as missas, além de bandas de música tocando em coretos especialmente montados para os festejos defronte à igreja.

Nas Vilas de Santo Amaro, Bela Cintra, Bela Vista, Braz, N. Sra. Auxiliadora, Santa Cruz do Glicério, Tabatinguera ou do Aterrado no Braz, havia as festas do Divino Espírito Santo. Àquele momento eram bem conhecidas na cidade e realizadas em datas distintas, seguindo ritos comuns. Contavam com a participação das bandas na missa, procissão, quermesse, leilões de prendas e retretas ao final da noite, tocando geralmente em palcos defronte às igrejas exclusivamente montados para essa finalidade durante os festejos, os quais eram posteriormente desarticulados. O Correio Paulistano de 21 de dezembro de 1890 traz a seguinte nota sobre a Festa do Divino Espírito Santo da Bela Vista:

FESTA DO DIVINO ESPÍRITO SANTO DA BELLA VISTA
PROGRAMA:
Hoje, domingo, 21 de dezembro, às 10 e $1 / 2$ da manhã, será cantada pelo
revdmo. sr. vigário da Consolação uma missa solemne, acompanhada de
côro e orchestra, orando o Evangelho o muito illustrado orador sacro, o sr.
conego Bejnamim, terminando a festa pela eleição da nova mesa
administrativa para o anno de 1891 , com as salvas de estylo.
Às 4 horas da tarde terá principio o importante leilão de prendas
offereceidas para esse fim.
Uma linda ouvertura executada pela banda de música do $10^{\circ}$ regimento de
cavalaria que se presta a abrilhantar o acto dará princípio ao leilão.
A mesma banda em todos os intervalos se prestará a tocar.
Findo o leilão, será queimado um importante fogo de artifício.
Para maior brilhantismo da festividade, estará hoje franca a AVENIDA
PAULISTA, no fim da rua. [...] onde se acha edificada a capella do Divino
Espírito Santo, a qual por suas dimensões e belezza é um dos mais
pittorescos e dignos passeios para as famílias desta capital. ${ }^{52}$

\footnotetext{
${ }^{51}$ BRUNO, Ernani Silva. História e tradições da cidade de São Paulo. Rio de Janeiro: José Olympio Editora, 1954. v. III., p. 1225.

${ }^{52}$ Festa do Divino Espirito Santo da Bella Vista. Correio Paulistano, São Paulo, 21 dez. 1890.
} 


\subsection{Outras comemorações}

Fora do circuito religioso, havia também as festas cívicas ou militares que se tornavam motivo para tocatas, desenvolvendo e imprimindo um ritmo e ritos próprios por meio das formas de se comemorar determinadas datas. A rotina desses dias começava sempre por uma "alvorada festiva", ${ }^{53}$ normalmente entre cinco e seis horas e da manhã, em frente às residências de personalidades políticas do executivo estadual, para depois seguirem pelas ruas da cidade acordando a população. Após a alvorada, os músicos poderiam descansar um pouco para que, no período da tarde, voltassem a tocar em concerto ou retreta em outro espaço público, como coretos nos largos ou nos parques.

Algumas das festas reportadas trazem o caráter solene dado à tentativa da construção de uma poderosa identidade republicana pela fixação de uma memória coletiva, contando com o apoio sonoro e visual no espetáculo das bandas que percorriam as ruas, estações, largos e jardins públicos nessas datas cívicas, tocando marchas, hinos e dobrados característicos e próprios dessas datas. Tal aspecto será discutido logo mais adiante.

A rotina do dia de ano novo ou de "ano bom" ( $1^{\circ}$ de janeiro $)$ iniciava-se, por exemplo, com alvorada festiva a cargo da Banda de Música da Força Pública do Estado, partindo do Quartel da Luz em direção ao Largo do Palácio (mais tarde, Palácio Campos Elíseos). Tocando a alvorada para despertar o Governador e seu staff, a Banda saía em desfile pelas ruas da cidade, cumprimentando a população, e anunciando mais um ano novo. Por volta da uma hora da tarde, retornava ao Palácio do Governo para tocar na recepção de cumprimentos do Exmo. Presidente, cerimônia que durava a tarde toda de primeiro de janeiro. À noite, geralmente dava concerto no Jardim do Palácio e no Jardim da Luz. ${ }^{54}$

A Constituição Republicana promulgada em 24 de fevereiro de 1891 também possuía comemorações, como elemento mnemônico republicano a ser preservado, A rotina dessas

\footnotetext{
${ }^{53}$ A alvorada festiva era uma forma de apresentação musical em que, às primeiras horas do dia, a banda de música se posicionava geralmente no principal espaço político ou histórico da cidade (praça central ou sede dos poderes) e, rompendo marcha executando um dobrado, seguia para as janelas de personalidades de vulto, acordando-as com seu som. Após a abertura das janelas e o cumprimento, era comum a solicitação de uma música por parte do cumprimentado, ao que a banda atendia. Terminada a execução, outras visitas se faziam até que, ao findar essa rotina, o conjunto desfilava brevemente pelas principais ruas da cidade, seguindo finalmente para sua sede. Nas pequenas cidades do interior de São Paulo e demais estados, essa ainda é uma prática cultural vigente, especialmente nos dias de comemoração de aniversário do município.

${ }^{54}$ Notas e factos. Correio Paulistano, São Paulo, p. 2, 1 jan. 1902.
} 
comemorações era quase a mesma do ano-novo: alvorada e concertos nos períodos da manhã e noite.

Como primeiro feriado republicano estabelecido, as comemorações de Tiradentes, em 21 de abril, receberam um tratamento mais apurado. Na Capital Federal, diversas bandas realizavam desfiles em honra à figura de Joaquim José da Silva Xavier. Em São Paulo, o rito seguia a rotina de alvorada, desfiles e concertos nos períodos da manhã, tarde e noite. A comemoração da Descoberta do Brasil também contava com um dia de festividades e presença oficial da Banda Militar, celebrada a 3 de maio de cada ano. Só na década de 1930, a data seria alterada para o 22 de abril, sem, contudo, se configurar feriado nacional:

Hoje, dia de festa nacional, comemorativa da descoberta do Brasil, não funcionarão as repartições públicas, que se conservarão embandeiradas, os bancos, a Bolsa e a Associação Commercial.

Os estabelecimentos commerciaes fecharão ao meio dia.

Haverá alvorada solene nos quarteis, onde será consideravelmente melhorado o rancho.

Serão postas em liberdade as praças que se acham presas disciplinarmente. $\mathrm{O}$ sr. vice-presidente do Estado telegraphará aos srs. vice-presidente da República, governadores e presidentes dos Estados, presidentes do Senado e Câmara, felicitando-os pela data de hoje.

À noite, serão iluminadas as fachadas das repartições públicas, realisandose das 7 às 9 horas, no coreto do Jardim do Palácio, um grande concerto pela banda de música da Força Pública, sob a regência do tenente Joaquim Antão Fernandes. ${ }^{55}$

É interessante notar que as comemorações não eram restritas ao poder público, já que o mesmo artigo fornece a indicação de outra famosa corporação tomando parte nos festejos, porém longe da cobiçada concha acústica do Jardim do Palácio ou do coreto da Luz:

- Para commemorar a data de hoje, o Centro Republicano Operário da Lapa, realizará uma sessão cívica em sua sede.

Começará o festival pelo hymno brasileiro, cantado por um côro de meninas, filhas de operários, discípulas do director da banda.

Em seguida haverá uma conferência sobre o facto histórico, pelo presidente do Centro Republicano Operário da Lapa, o sr. Antonio Lacerda Urioste. Terminará a festa com a execução dos hymnos nacional e de Garibaldi. A's 6 e meia horas da tarde, haverá concerto pela mesma banda de música, em frente ao Salão Internacional da Lapa.

${ }^{55}$ Três de maio. O Estado de São Paulo, São Paulo, 3 mai. 1910. Notícias Diversas, p. 3. 
Durante as festas tocará a banda de música, dirigida pelo sr. Victor Arrigo. ${ }^{56}$

As celebrações da Abolição da Escravidão (13 de maio) também passaram a ser comemoradas com a mesma solenidade que as demais datas cívicas, corroborando as relações entre o abolicionismo e a República. A rotina seguia a mesma das demais, ou seja, repartições públicas, consulados, bancos, casas comerciais e até mesmo a Bolsa de Valores se faziam embandeiradas e enfeitadas. Alvorada festiva no Quartel da Luz, tocada pela Banda de Música da Força Pública e concertos e apresentações nos períodos da tarde e noite. Em 1910, o Estado de São Paulo apontava que a referida Banda se fazia acompanhar por tambores e cornetas,${ }^{57}$ dando um caráter mais solene e de completude ao grupo musical. Os soldados tiveram um rancho melhorado e vestiram uniformes de gala para o serviço do dia. Das 7 às 9 horas da noite, houve um concerto em comemoração à data, no coreto do Jardim do Palácio pela mesma Banda, regida pelo tenente Joaquim Antão Fernandes. Outro registro noticia uma festa realizada no Centro da Federação dos Homens de Cor em São Paulo, levada a cabo na sede do Centro Gallego, que foi abrilhantada pela primeira Seção da Banda de Música da Força Pública. Há ainda outras menções, como as festas em Santo Amaro envolvendo a Banda de Música do Clube Treze de Maio daquela localidade, cujo objetivo era o mesmo: comemorar a data da abolição. Curiosamente, aquela Banda fora regida pelo maestro Joaquim Antão Fernandes da Força Pública nos idos de 1889 e 1891, quando este estivera fora da Força Policial.

A data de 14 de julho era reservada para se comemorar a Queda da Bastilha e a Constituição Paulista. Em 1910, O Estado de São Paulo indicou, na edição de 15 de julho, que, mesmo enfrentando chuva e frio, três mil pessoas estiveram nas comemorações da Queda da Bastilha, realizada aquele ano no Parque Antarctica. ${ }^{58}$ Para compreender o número de público presente, há que se pensar nas relações entre a implantação do regime republicano e a Queda da Bastilha na França, como um símbolo de modernização e autoafirmação desse regime político. Novamente a cargo da Força Pública do Estado, o evento contou com a

\footnotetext{
${ }^{56}$ Três de maio. O Estado de São Paulo, São Paulo, 3 mai. 1910. Notícias Diversas, p. 3. É muito provável que a banda de música, ainda que não mencionada pelo artigo, se trate da União Operária da Lapa, conforme Tabela 16 (Anexo I).

${ }^{57}$ Treze de maio. O Estado de São Paulo, São Paulo, 14 mai. 1910. Notícias Diversas, p. 4.

${ }^{58}$ Quatorze de julho. O Estado de São Paulo, São Paulo, 15 jul. 1910. Notícias diversas, p. 6.
} 
participação da Banda completa dessa instituição, sua tropa e regimento de cavalaria, agregando-se ao conjunto ainda a banda de clarins. É importante notar que, não por acaso, no repertório estiveram Hino Nacional Brasileiro, Marchas, Dobrados e A Marselhesa, ou seja, a representação sonora republicana exibiu um de seus mais claros símbolos.

As comemorações da Independência seguiram por rumos assimétricos entre o final do $2^{\circ}$ Reinado e a Era Vargas. Em 1888 (pouco mais de um ano para a chegada da República), o Correio Paulistano de 6 de setembro trazia uma nota onde se pode perceber a grandiosidade atribuída à data. Nela, eram reportadas as comemorações que ocorreriam na cidade do Rio de Janeiro, porém, há que se entender que a mesma suntuosidade valia para todas as demais cidades do país (guardadas as devidas proporções e o status de capital do Império que aquela cidade exibia):

\section{Sete de Setembro}

Na côrte, a 7 do corrente mez, dia de grande gala, por ser o do anniversario da independência do Império, S M. o Imperador assistirá ao Te Deum que se há de, ao meio dia, celebrar na Capella Imperial.

Depois do Te-Deum haverá cortejo no paço da cidade. [...]

Seguir-se-á: ouvertura (Vesperas Siciliana) pelas bandas dos menores do arsenal da guerra, corpo de polícia da côrte e imperiaes marinheiros [...] Marcha Triumphal executada por todas as bandas $[\ldots]^{59}$

No entanto, a partir da República, a importância atribuída às datas comemorativas se alterou. Perdendo momentaneamente seu brilho a partir de 15 de novembro de 1889 , o 7 de setembro tornou-se uma data secundária por um longo período, em razão de sua memória atrelada à família imperial, que fora destituída. Nesse cenário, as festas e comemorações da Independência passaram a seguir um tom de menor pompa. Em 1904, por exemplo, não houve destaques na grande imprensa para desfiles das Forças Armadas ou da Força Pública, ao contrário do que ocorreu com os desfiles nos Prados da Mooca, como os que passaram a ocorrer todo 15 de novembro a partir de 1906. Para o 7 de setembro, eram reservados concertos musicais pelas bandas da própria Força no Jardim do Palácio e outras, como a Giuseppe Verdi, no coreto do Largo do Rosário, conforme se encontra em O Estado de São Paulo de 7 de setembro de $1904 .{ }^{60}$ Contudo, gradativamente, as comemorações da data

\footnotetext{
${ }^{59}$ Sete de setembro. Correio Paulistano, São Paulo, p. 1, 6 set. 1888.

${ }^{60}$ Notícias diversas. O Estado de São Paulo, São Paulo, p. 3, 7 set. 1904.
} 
voltaram a ter importância. Em 1910, por exemplo, já se teve notícia delas na cidade de São Paulo, como um feriado qualquer, seguindo o mesmo rito, porém sem desfiles: Alvorada pela manhã, cumprimentos ao Presidente do Estado com direito a banda tocando no Largo do Palácio, concerto à tarde e à noite. Naquele ano, as festas realizaram-se no Parque do Ipiranga, contando com a participação de estudantes, além das autoridades e das bandas. À noite, dando um arremate especial à data, a Força ainda dispôs de um efetivo de mil soldados para uma Marche aux Flambeaux no Largo do Palácio, compondo o conjunto musical a Banda de Música completa acrescida da banda de clarins e tambores do Regimento de Cavalaria também da Força Pública. Há ainda, a informação capturada e retratada pelo quadro Festa escolar no Ipiranga do pintor Agustín Salinas Teruel (1869-1923) datado de $1912^{61}$, onde se pode notar a participação de escolares e uma grande banda de música que, pelas características do uniforme que trajava, era a da Força Pública a sonorizar o evento.

A grande representação do retorno da importância da data foram as comemorações do centenário da Independência, em 1922, que incluíram atividades realizadas nos Jardins do Museu do Ipiranga. A Banda de Música da Força Pública tomou parte nessa festa, contando com as seções da capital, quatro bandas convidadas do interior do estado, banda de clarins, cornetas e tambores do Regimento de Cavalaria, mais quatro mil vozes de alunos de estabelecimentos de ensino da cidade de São Paulo, interpretando o poema sinfônico $O$ Centenário, com música de Savino De Benedictis e letra de Henrique Macedo. ${ }^{62}$ Esse evento será melhor detalhado no capítulo 3. Apagada novamente a partir de 1923, em 1929, a data seria lembrada em uma pequena “cabeça de nota” em O Estado de São Paulo, sem que este, contudo, detalhasse seus festejos. ${ }^{63}$

O Dia da Descoberta da América era comemorado em 12 de outubro e, em 1892, celebrou-se seu quarto centenário. Para festejar a data, organizou-se um programa composto de alvorada contando com três bandas de música que também tocaram o dia todo. ${ }^{64}$ Foi organizado um cortejo cívico na forma de um préstito que, saindo do Jardim da Luz, seguiu pelas ruas Florêncio de Abreu, Boa Vista, 15 de Novembro, do Rosário, São Bento, Direita,

\footnotetext{
${ }^{61}$ SALINAS, Augustín Teruel. Festa escolar no Ipiranga. Óleo sobre tela. Acervo da Pinacoteca do Estado de São Paulo.

${ }^{62}$ DELLA MONICA, Laura. História da Banda de Música da Polícia Militar do Estado de São Paulo. 2. ed. São Paulo: Edanee, 1975. p. 66

${ }^{63}$ O dia da Independência. O Estado de São Paulo, São Paulo, 8 set. 1929.

${ }^{64}$ As bandas aqui referidas foram: Umberto I, Giuseppe Verdi e Guido Mônaco.
} 
Marechal Deodoro, Theatro, Quintino Bocaiúva, Senador Feijó e terminou no Largo de São Francisco. ${ }^{65}$ Nos anos seguintes, as comemorações seguiriam um rito muito parecido, porém contando com um menor número de pessoas e corporações, cumprindo, dessa forma, sua função de monumento à memória de Colombo e sua saga, até a data cair no esquecimento e deixar de ser comemorada na segunda metade do século XX.

Como foi citado, a memória republicana guardou consigo, para toda essa geração nascida a partir do final do século XIX, a lembrança dos desfiles nos Prados da Mooca, como representação das comemorações do 15 de novembro. Contando com as tropas e bandas de música da Força Pública do Estado, além das presenças do Presidente, Vice-presidente do Estado e demais autoridades do executivo, legislativo e judiciário. Ao passo das duas próximas gerações, porém, a data máxima republicana também cairia no limbo comemorativo, em meio às mudanças políticas pelas quais o país passaria, cujo tom de urgência para a redemocratização a partir do final da Era Vargas se faria mais forte do que as memórias do final do Império e do despertar da República.

Além do aspecto político e da propaganda, as bandas tornaram-se importantes pontos de apoio, como ferramentas de campanhas sociais das mais diversas formas, que, muitas vezes, incluíam o levantamento de fundos para inúmeras causas. Préstitos com o intuito de arrecadar verbas para os lázaros (hansenianos) eram muito comuns, ${ }^{66}$ préstitos esses, na maioria das vezes, noticiados pela imprensa e apreciados com grande simpatia pela população. No contexto da assistência social, outro ponto em comum eram as participações em outros tipos de eventos, como: festas, quermesses, chás e reuniões beneficentes, envolvendo sociedades que se prestavam especificamente a essa finalidade, como a Associação Feminina Beneficente e Instructiva. Em carta assinada pela Profa. Anália Franco, registrava-se um público agradecimento ao comandante da Força Policial do Estado pela gentileza da cessão da Banda de Música dessa instituição para a festa em prol daquela Associação. ${ }^{67}$ Eventos beneficentes em favor da Santa Casa de Misericórdia ou outros hospitais, como a Maternidade São Paulo, também eram realizados dentro dessa lógica colaborativa com o apoio desses grupos musicais:

\footnotetext{
${ }^{65}$ Crhistovam Colombo. Correio Paulistano, São Paulo, p. 1, 12 out. 1892.

${ }^{66}$ Para os lázaros. Correio Paulistano, São Paulo, 13 nov. 1888. Boletim, p. 2.

${ }^{67}$ FRANCO, Anália. Agradecimento. O Estado de São Paulo, São Paulo, 20 set. 1902. Secção Livre, p. 3.
} 
Foi um verdadeiro sucesso o festival realizado hontem no Parque da Antarctica Paulista em benefício da Maternidade de São Paulo.

A Commissão organisadora da batalha de flores, deve estar orgulhosa do resultado que obteve, graças aos seus esforços; não é justo, comtudo, deixar de registrar a boa vontade de nossa população que francamente secundou o trabalho da commissão, concorrendo no festival.

Calculamos em perto de 15 mil pessoas a assistência que ontem se espalhou pelas alamedas e jardins do Parque da Antarctica. Em todas as diversões reinou a melhor ordem, confirmando-se assim mais uma vez a índole pacífica e disciplinadora da nossa população. Numa agglomeração tão numerosa em que se achavam representadas todas as camadas sociaes, não houve o menor distúrbio, o mais insignificante attrito. E isto é tanto mais para admirar quanto as diversões de hontem eram uma perfeita novidade no nosso meio. [...]

[...] Próximo à archibancada que foi construída com tijolos e madeira, erguiase um elegante coreto, onde durante o dia e parte da noite, tocou uma seção da banda de música policial e na parte de dentro do ground, era uma legião de pequenos chalets com orchideas emergindo graciosamente dos macissos de folhagens.

Nas extremidades das archibancadas tocavam mais duas bandas de música outra num coreto do parque e no centro do bosque a orchestra de tziganos $[\ldots]^{68}$

Campanhas de solidariedade em favor de arrecadação de mantimentos ou verbas para flagelados também eram comuns. Em 1903, há o registro de uma delas em favor de Cabo Verde e da seca no Ceará, desenvolvida pela Sociedade Portugueza Beneficente Vasco da Gama, cuja participação da União Internacional do Braz e sua respectiva banda de música foi primordial. ${ }^{69}$ Quermesses beneficentes para o levantamento de fundos a abrigos e outros tipos de entidades traziam sempre bandas, não apenas no sentido da música e seu deleite durante os intervalos dos leilões de prendas, mas sobretudo como fator de atração de público, o que acabava por garantir uma boa arrecadação. É interessante notar que, à medida que o século XX avançou, o resultado do desenvolvimento industrial e social da cidade alavancou, consequentemente, as solicitações de participações das bandas de música nos eventos, em uma demanda crescente até o final da década de 1910. A partir de 1920, a dinâmica mudaria, possivelmente em razão da massificação dos discos e gravações e da possibilidade de utilização dos equipamentos reprodutores (gramofones) nos ambientes fechados em vez das bandas ao vivo. No entanto, é essencial pensar que, ainda naquele momento (primeira e segunda décadas do XX), as ruas de São Paulo eram coloridas pelos acordes das bandas.

\footnotetext{
${ }^{68}$ Batalha de flores. O Estado de São Paulo, São Paulo, 12 out. 1903. Notas e informações, p. 1.

${ }^{69}$ Movimento associativo. O Estado de São Paulo, São Paulo, p. 2, 2 out. 1903.
} 
É preciso também lembrar que o tecido sonoro da cidade no primeiro período republicano era muito diverso e composto de uma infinidade de elementos; alguns dos quais já se perderam ao longo do tempo (como é o caso das companhias equestres); outros ainda teimam em prevalecer, resistindo às agruras da modernidade e tecnologia, como é o caso do circo. No primeiro caso, as Companhias Equestres (às vezes, parte de um circo, às vezes, solo), eram compostas de animais e cavaleiros que produziam apresentações a um público pagante. De caráter itinerante, viajavam pelo estado e país na mesma dinâmica dos circos e, também em semelhança a eles, geralmente possuíam bandas de música próprias ou contratadas na localidade para animar seus espetáculos. Em sua autobiografia, o major Joaquim Antão Fernandes, maestro da Banda de Música da Força Pública, ${ }^{70}$ afirma que, durante o ano de 1888, por ocasião de sua baixa à instituição, ingressou em uma Companhia Equestre, viajando pelo interior do estado de São Paulo, visitando as cidades de Sorocaba, Botucatu, São Manoel, Piracicaba e Rio Claro, tendo deixado a referida companhia após seu retorno a São Paulo.

No segundo caso (o circo), o tratamento dado a esse importante agente cultural naquele momento e que ainda persevera é um pouco mais elaborado pela história da cultura. O circo tornou-se parte integrante desse universo cultural até o tempo presente. Vários memorialistas descrevem com detalhes as apresentações de companhias de circo na cidade de São Paulo, durante os primeiros decênios do século XX. Embora reduzida e quase sempre pequena, era comum haver uma banda em cada circo. Zélia Gatai descreve esse ambiente:

Infelizmente raro, o circo era o programa que mais nos enchia de entusiasmo. Íamos apenas aos que erguiam seu toldo uma vez na vida, outra na morte, num terreno baldio em frente ao "Cinema América". Por lá passaram alguns circos famosos. Faltou o "Sarrazani", grande demais para as dimensões do terreno da Consolação. Desse apenas tive notícias e não passei da vontade de vê-lo. Em compensação, não faltei ao "Circo Pio-lim", ao dos "Irmãos Queirolo" e à vários outros, estupendos. [...]

A banda do circo mexia comigo; seus dobrados, me davam vontade de sair dançando, participar dos números no picadeiro ao lado dos artistas. ${ }^{71}$

O circo, como agente cultural itinerante, representava a arte em suas diversas formas. Assim, sempre manteve características históricas de comunicação com o "grande público”,

\footnotetext{
${ }^{70}$ FERNANDES, Joaquim Antão. Minha autobiografia. São Paulo: Sem editora, 1943. p. 5 Mimeografado.

${ }^{71}$ GATTAI, Zélia. Anarquistas graças a Deus. São Paulo: Companhia das Letras, 2009. p. 22-23
} 
ou seja, as massas. Naquele momento em que a "era da reprodutibilidade técnica"72 ainda não havia sido inaugurada nem os amplificadores sonoros e instrumentos elétricos faziam parte de seu aparato, era também por meio dos circos que as camadas operárias urbanas e as comunidades rurais buscavam diversão. Aos finais de semana, era para o circo que os trabalhadores agrícolas corriam nas longínquas cidadezinhas do interior do país, onde jamais pisaria uma orquestra ou grupo de teatro. Para essa população, assim como para o operariado urbano, muitas vezes, o único palco a que se conseguia ter acesso era o picadeiro, com seu teto coberto de lona.

Em síntese, os maiores e mais utilizados palcos das bandas de música durante os anos da Primeira República foram sem dúvida os espaços públicos abertos (a rua, os largos e os coretos de jardim). Não por acaso o imaginário brasileiro guarda ainda uma visão romântica da banda tocando enquanto as famílias sentadas ao redor do coreto comem pipoca, amendoim, os adultos conversam e as crianças brincam ao som de um maxixe ou de uma polca. Mas, se, para a maioria da população, a única possibilidade de ouvir a banda era nas ruas ou no coreto, para outros bolsos, era possível, em outros lugares, ouvir orquestras.

\subsection{Espaços públicos fechados}

Assim como os teatros cobravam ingressos para as apresentações das companhias de ópera e suas orquestras, as associações culturais ligadas ao movimento imigrante também selecionavam seu público através de critérios muito semelhantes. Caso a entrada fosse franqueada, o público para o qual o espetáculo seria dirigido seria normalmente de seus associados. E vale lembrar que as associações e os teatros, são apenas duas das possibilidades de espaços públicos fechados que os grupos musicais ocupavam. Cafés, cafés-concerto, rotisseries, hotéis além de clubes e associações, são outros exemplos.

A respeito dos espaços públicos ocupados pelos grupos musicais existentes, há que se entender que os teatros instalados em São Paulo ao longo do século XIX recebiam diversos grupos artísticos e musicais; as bandas, porém, como organização e corpos estáveis estavam, na maioria das vezes, à margem desses teatros. Dentre eles, os principais, como o Polytheama na avenida São João, o Sant'Anna na rua Boa Vista, o São José no Largo Municipal, atual Praça João Mendes, e o Colombo no Brás, somente no último quartel

\footnotetext{
${ }^{72}$ BENJAMIM, Walter. A obra de arte na era de sua reprodutibilidade técnica. Porto Alegre: Zouk, 2012.
} 
daquele século passaram a receber as bandas de música, quer de forma a completar seus espetáculos de ópera, quer em apresentações próprias, caracterizadas por repertórios específicos para comemorações de datas especiais ou, simplesmente, como concertos de programação corriqueira ou beneficente. ${ }^{73}$ De acordo com as fontes, raramente as bandas ocupavam os palcos dos teatros. Seu lugar social, em um primeiro momento, era restrito ao saguão de entrada e/ou restaurante, ${ }^{74}$ deixando-se às orquestras e grandes companhias de ópera o privilégio de se apresentarem em seus glamorosos palcos. Revelava-se, dessa forma, uma certa hierarquia dissimulada dentro do mundo musical (orquestra versus banda), que teima em permanecer até os dias de hoje. ${ }^{75}$ Não obstante esse fato, há raríssimos artigos de concertos realizados por bandas nesses mesmos espaços, e que, quando aconteceram, o foram sob certas condições, como em eventos beneficentes por exemplo. A ocupação dos suntuosos espaços dos teatros, no entanto, tornar-se-ia mais rotineira a partir da década de 1920, como veremos no capítulo 3.

A forma mais comum de eventual uso do palco pelas bandas, normalmente atribuído exclusivamente às orquestras, dava-se pelo convite para tomar parte no conjunto orquestral quando o compositor assim o delimitava em sua escrita musical. Como exemplo, podemos citar a abertura de $\mathrm{P}$. Tchaikovsky 1812, que contém uma fanfarra sobreposta à orquestra em sua seção final. Dessa forma, quando essa abertura era executada por alguma orquestra, requisitava-se parte de uma banda de música para encorpar e completar a composição dentro do conjunto que executava a obra, obtendo-se, portanto, a fanfarra.

A partir de 1911, um novo palco tornar-se-ia o mais cobiçado da cidade - o Teatro Municipal, ${ }^{76}$ o que acirraria os ânimos entre os grupos musicais paulistanos para terem o privilégio de o ocuparem. Como nos demais casos, o espaço reservado, na maioria das vezes, às bandas de música eram suas escadarias ou jardins do entorno - a Esplanada (área externa do edifício), o restaurante (frequentado a partir de então pela elite paulistana) ou o saguão de entrada (área interna, antessala do edifício). Cumprindo as funções de alegrar jantares ou

\footnotetext{
73 Theatro S. José. Correio Paulistano São Paulo, 19 dez. 1890. Annuncios, p. 4.

${ }^{74}$ Theatro S. José. Correio Paulistano, São Paulo, p. 1, 31 out. 1888.

${ }^{75}$ É comum ainda hoje a preservação de uma certa "distância social velada" entre os músicos de banda e os de orquestra, em que pese muitas vezes o repertório tocado, a técnica de execução instrumental e a formação em síntese serem as mesmas.

${ }^{76}$ MAGALHÃES, Paulo Ribeiro. A fundação do Teatro Municipal. Revista do Arquivo Público Municipal, São Paulo, v. 16, p. 127-131, ago. 1935.
} 
banquetes, no caso do restaurante, as bandas viam o palco apenas de longe. Outra função muito comum das bandas no Teatro Municipal era a de recepcionar autoridades em eventos oficiais, porém também limitando-se à área externa (escadarias) ou à interna (saguão).

Dentre os espaços públicos fechados existentes na cidade, outros de frequência assídua para as bandas e de igual importância eram os salões dos clubes e associações onde se realizavam bailes comuns ou de carnaval, além de reuniões, jantares e banquetes. Inúmeros outros espaços faziam a alegria dos grupos musicais, como as rotisseries e cafés, configurando-se ambientes para que orquestras pequenas ou bandas tocassem durante grandes banquetes, jantares ou mesmo em apresentações rotineiras, sendo a maioria deles cobertos pela grande imprensa. Para os grupos musicais menores, a confeitaria Fasoli, no centro da cidade (Rua Direita), viria a ser também um requintado espaço de apresentações, abrigando concertos de música de câmara e recitais.

Em diversos salões da cidade, bailes eram abrilhantados por bandas. Clubes, associações, agremiações contratavam músicos e montavam seus grupos musicais para animar o carnaval, gerando conjuntos sazonais, próprios para essa exclusiva finalidade, prática que, em alguns casos, perdura até os dias de hoje. Não rara era a contratação de bandas já consolidadas para a animação desses bailes carnavalescos até mesmo em teatros. No carnaval de 1889, o Theatro São José convidava o "seleto público" para os festejos do último carnaval monarquista, como anunciava A Província de São Paulo:

GRANDES BAILES do carnaval de 1889! No THEATRO S. JOSÉ nas Noites de 2,3,4, e 5 de março Sabbado, Domingo, Segunda e Terça-feira. O THEATRO S. JOSÉ, devendo nesses dias receber a elite da sociedade paulistana, achar-se-á adornado a capricho, não se tendo o seu proprietário recusado a despeza alguma para transformal-o, pela grandiosidade, bom gosto e elegância das decorações, em um perfeito EDEN, onde as noites se passem rápidas, onde as horas semelhem segundos apenas.

A magnifica banda do Corpo Policial Permanente estuda desde já, apressadamente para os feéricos bailes do S. JOSÉ, novas e lindíssimas quadrilhas, valsas etc.

GRANDES E ESPLENDOROSOS BAILES SERÃO OS MELHORES ATÉ HOJE DADOS NESTA CAPITAL. ${ }^{77}$

\footnotetext{
${ }^{77}$ Grandes bailes do carnaval de 1889. A Província de São Paulo, São Paulo, 14 fev. 1889. (Grifo no original).
} 
Com o passar do tempo e a evolução tecnológica, essas bandas carnavalescas ${ }^{78}$ foram se reduzindo a conjuntos que, da formação anterior, preservaram apenas a percussão na forma de uma bateria americana e surdos; e do naipe dos sopros, apenas um saxofone, um trompete e um trombone, que passaram a acompanhar a "cozinha" composta pela percussão, contrabaixo e piano, além dos cantores. Dessa formação original, as tubas (souzafones em Mi $b$, e Si $b$ ), bombardões, bombardinos e toda a família dos sax-horns, além das trompas e sarrusofones quando existentes, perderam seus empregos ao longo do século XX para essa tecnologia que passou a incorporar, a partir da década de 1920, o estilo jazz band de se tratar a música de conjunto, o que mudou, portanto, o universo sonoro e visual desses recintos. Apenas nos carnavais das praças e ruas, esses instrumentos ainda resistiram e continuam hoje a ser utilizados, não apenas pela dificuldade de alimentação por energia elétrica de seus adversários, mas também pela característica da força empregada na produção do som, que sempre trouxe excelentes resultados nos conjuntos de características acústicas.

No chamado triângulo do centro da cidade, havia lugar para todos os tipos de associações, clubes e entidades de classe. Dentre aqueles frequentados por músicos, esteve o Frontão Boa Vista, que corroborou as relações de poder entre as bandas de música nessa dinâmica musical paulistana. O Frontão era um espaço para a prática de esportes (pelota basca $^{79}$ e mais tarde o futebol), muito frequentado pela elite paulistana. Inaugurado em fevereiro de 1898, o Frontão tinha sua entrada pela rua de mesmo nome, $n^{\circ} 48$, esquina com a Ladeira Porto Geral, por meio de um portão de ferro que levava a um corredor ladrilhado que chegava à bilheteria. Possuía arquibancadas, construídas em pinho de riga sobre os alicerces de tijolos, de onde se avistava seu campo. Tinha ainda camarotes, botequim com varanda de onde se podia ver o Tamanduateí e apreciar a vista da Ladeira Porto Geral tomando refrescos, além de toillete para senhoras e um escritório. Além dos aposentos descritos, era provido de vestiários para os jogadores, enfermaria, camarins, chuveiros e guarda-roupas, sendo todos os espaços ventilados por janelas que davam exaustão à Várzea do Carmo $^{80}$. Sempre aos domingos, a grande imprensa noticiava partidas de jogos a serem

\footnotetext{
${ }^{78}$ Embora se trate de bandas carnavalescas, o ambiente em questão era público fechado: teatro.

${ }^{79}$ Pelota basca é um esporte existente ainda nos dias de hoje, originário do País Basco, onde os jogadores portam bastões de madeira (raquetes) e arremessam a bola a uma parede. Em razão das apostas que se podiam fazer nas equipes que disputavam as partidas, esse esporte foi proibido no Brasil a partir do Estado-Novo.

${ }^{80}$ PINTO, Alfredo Moreira. A cidade de São Paulo em 1900: impressões de viagem. Rio de Janeiro: Imprensa Nacional, 1900. p. 173-175.
} 
disputadas no Frontão, apresentando como atração entre os intervalos "uma excelente banda de música". O Correio Paulistano de 29 de novembro de 1903 trazia a seguinte nota sobre a rotina dessa casa:

\section{Frontão Boa Vista}

O grupo e amadores do "Club Athletico da Pelota", disputará quinielas das 8 às 11 da manhã.

Ao meio-dia começará o espetáculo domingueiro daquella casa de diversão, como sempre cheio de attractivos.

Uma banda de música tocará durante os intervalos. ${ }^{81}$

Encerrando o ano, festas de Natal nas diversas entidades também eram comumente pontilhadas de bandas de música, assim como o eram as festas de finalização de ano letivo nas escolas e suas respectivas colações de grau, que traziam a participação de bandas para maior brilhantismo dessas solenidades.

Em resumo, os grupos musicais, estavam distribuídos pela cidade, ocupando os espaços possíveis e disponíveis, de acordo com a oportunidade e a conveniência dos contratantes. Porém, no caso das bandas, elas mesclavam os espaços públicos abertos e fechados, cumprindo diversos papéis. A mesma banda que tocava no Palácio do Governo do Estado, tocava também no Jardim da Luz ou no Largo do Palácio. Ocupar e demarcar esses espaços foi uma forma de representação e reafirmação de poder, uma vez que alguns deles, como vimos, foram cobiçados pelas bandas durante longo tempo.

\section{As bandas da cidade}

Após havermos compreendido como a cidade evoluiu e como o espaço musical paulistano estava estruturado no início do século $\mathrm{XX}$, ajustemos um pouco mais nosso foco para que possamos entrar de fato no mundo das bandas. Bem maior do que se pensava, o time que compunha as referidas bandas - denominadas de Liras, Corporações Musicais e Filarmônicas (quando civis), ou Grandes Bandas no caso das militares - surpreendeu não apenas no aspecto numérico mas também no qualitativo, como veremos a seguir.

As bandas de música, aproveitando as boas condições fornecidas pelo desenvolvimento urbano, multiplicaram-se por aquele novo e diversificado universo cultural,

\footnotetext{
${ }^{81}$ Divertimentos de hoje. Correio Paulistano, São Paulo, 29 nov. 1903. Factos Diversos, p. 3.
} 
como se pode identificar claramente na Tabela 16 do Anexo I, que demonstra a grande presença dessas bandas de música pela cidade. Os critérios para o mapeamento de tais corporações foram retirados das fontes primárias e da bibliografia. Contudo, nem sempre foi possível apresentar os dados completos ou sua evolução ao longo do recorte pesquisado (1888-1932), uma vez que, não raro, uma banda mudava sua denominação quando a associação ou sua instituição mantenedora assim também o fazia ou, ainda, se aquela instituição determinasse fosse pelos mais diversos motivos. Outra possibilidade de mudança na nomenclatura era a fusão de duas corporações que se juntavam formando uma nova. Quando fontes diretas e bibliografia citavam a mesma banda, optei por dar preferência à fonte direta. ${ }^{82}$ É necessário esclarecer que, por se tratar de um recorte relativamente longo para a pesquisa, não foi possível datar a presença e sucessão dos maestros nas respectivas bandas, salvo em raríssimas exceções, quando as fontes assim o permitiram. Para efeito de sistematização, estudo e análise nesta parte da pesquisa, as bandas foram divididas em categorias, conforme se propõe a seguir:

Tabela 1: Bandas encontradas na cidade de São Paulo entre os anos de 1889 e 1932, classificadas conforme as fontes, alimentada pela Tabela 16 - Anexo I (Números absolutos).

\begin{tabular}{|c|c|c|}
\hline & $\begin{array}{r}\text { Cidade de } \\
\text { Bandas de mús }\end{array}$ & \\
\hline 1. & Imigrantes e/ou associativas & 42 \\
\hline 2. & Indefinidas & 16 \\
\hline 3. & Militares & 13 \\
\hline 4. & Escolares & 8 \\
\hline 4. & Companhias, circos, carnaval & 8 \\
\hline 5. & Teatros & 2 \\
\hline & TOTAL DE BANDAS.. & 89 \\
\hline
\end{tabular}

\footnotetext{
${ }^{82}$ As fontes utilizadas para a composição das Tabela 1 e 16 foram: $O$ Estado de São Paulo nos anos de 1889, 1890, 1891, 1892, 1902, 1903, 1906, 1910, 1912 e 1915. Correio Paulistano nos anos de 1888, 1890, 1891, 1892, 1902, e 1903.
} 
Figura 5 - Gráfico representativo das categorias de bandas de música encontradas na cidade de São Paulo entre 1889 e 1932, em percentuais.

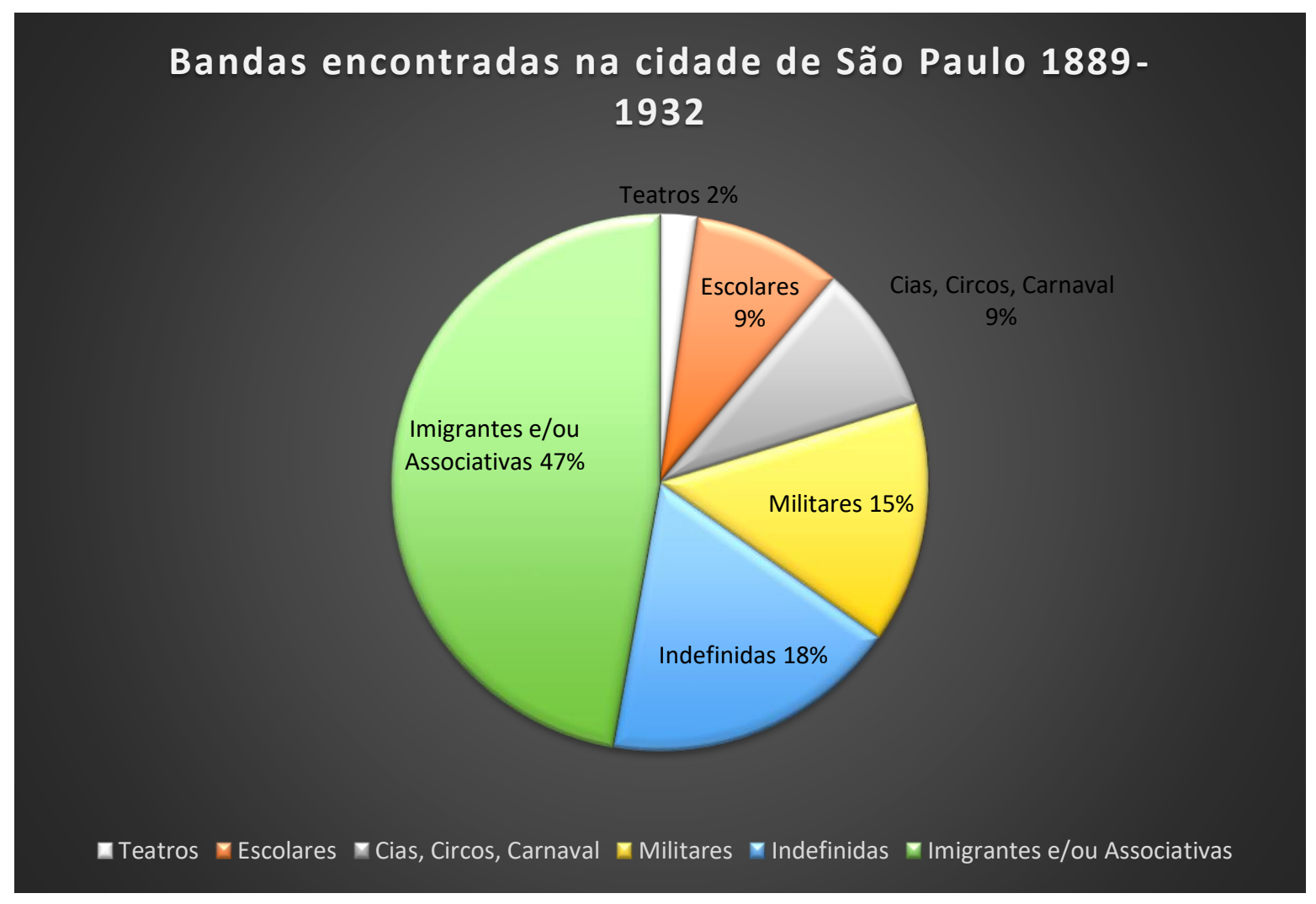

De um universo total de 89 bandas de música encontradas, $47 \%$, ou seja, 42 delas tinham origem nas relações com a imigração ou associações formadas por esses imigrantes, demonstrando claramente a influência destes na formação musical da cidade do início do século XX. O segundo maior percentual é representado pelas corporações indefinidas, já que nem todas elas traziam no nome ou nas fontes características que possam gerar uma perspectiva de classificação para o respectivo enquadramento. Em seguida, vieram as militares, com $15 \%$ do total. E, finalizando o arranjo, 9\% para bandas de carnaval e companhias de circo, em um total de oito, além de bandas escolares, também contendo oito bandas e, por último, duas corporações de teatro foram mapeadas, gerando um índice também aproximado de $2 \%$ delas. Dentro desse contexto, não se torna difícil entender o porquê dos elementos civis e militares cruzarem seus caminhos dentro dessa urbanidade por meio da música das bandas na São Paulo do início do século XX, pois (em não raros, e factíveis casos) 
músicos militares também exerciam as mesmas funções nas corporações civis em suas horas de folga, em que pese o aperto dos horários a que eram submetidos dentro da caserna.

É importante também ressaltar que, algumas dessas corporações listadas nos dados da Tabela 16 existiram por breves períodos, ou fundiram-se a outras ao longo dos anos; outras trocaram de nome e, possivelmente, muitas outras nem aparecem na pesquisa porque não foram localizadas na grande imprensa ou citadas pelas fontes. No entanto, a intenção da Tabela é demonstrar a importância desse organismo dentro da cultura urbana. Isso é perceptível pelo número de corporações que brotaram das fontes somente na cidade de São Paulo. Para uma melhor compreensão desse universo, no texto a seguir, as bandas estarão divididas em dois tipos: civis e militares. Iniciemos nossa análise mais detalhada pelas "paisanas".

Antes, porém, façamos uma pausa para explicitar os critérios de classificação das bandas. Nas bandas militares, estão classificadas as do Exército Brasileiro, Força Pública, Guarda Nacional Voluntários da Pátria e Guarda Civil de São Paulo (que, mesmo trazendo consigo o título de "Civil" é aqui enquadrada como militar por apresentar subvenção do Estado, pertencer a uma organização de caráter policial criada na gestão de Carlos de Campos, em 1926, trajar uniforme e conter todas as características de suas coirmãs militares). As bandas imigrantes e/ou associativas contemplam grupos pertencentes a associações de classe, como as do movimento operário, socorros mútuos, e as de cunho imigrante, como sociedades italianas, portuguesas, espanholas, francesas e alemãs. Escolares são grupos estabelecidos dentro de uma prática pedagógica interna às instituições regulares de ensino, sem, contudo, terem na música seu principal objeto e função. Teatros contemplam corpos fixos de músicos em caráter permanente com aquele estabelecimento, mediante contrato firmado entre os músicos e a casa de espetáculos, sem, contudo, haver cláusula de dedicação exclusiva. Companhias, circos e carnaval apresentam dois tipos de possibilidade: bandas das próprias companhias (caso mais comum para as companhias equestres) e bandas locais contratadas para essas atividades ou formadas exclusivamente durante a passagem dessas na cidade. O carnaval representa também a formação sazonal de bandas e charangas de execução de repertório típico da folia de momo. Indefinidas (para efeito deste trabalho) são as bandas que, por características diversas ou por não ser possível o entendimento de sua classificação através das fontes, foram então enquadradas nessa categoria. Escolas musicais é outra 
categoria de enquadramento que traz corporações fruto de práticas pedagógicas específicas dentro do universo musical, cujo objetivo seria o de formar músicos para atuação dentro da cena musical paulistana em seus mais diversos grupos e segmentos. No entanto, é importante salientar que, durante o recorte pesquisado, nenhuma banda ligada a esse tipo de instituição educacional foi localizada, o que não significa também que não possa ter existido. Exemplo disso foram grupos de câmara existentes dentro do Conservatório Dramático e Musical de São Paulo para o exercício da prática de orquestra. Porém, há que se entender que esses foram grupos formados por alunos e tiveram um objetivo pedagógico musical específico, desfazendo-se após o semestre ou ano letivo. Outro critério para a classificação dos grupos neste trabalho foi a preservação das informações originais fornecidas pelas fontes.

Tendo explicitado os critérios de classificação das bandas, voltemos, conforme prometido, para a análise mais detalhada das bandas paisanas. Dentre as bandas civis mapeadas, muitas delas povoaram a infância de memorialistas e historiadores em suas obras da São Paulo na Primeira República. Estes grupos tomaram parte da vida de pessoas e da cidade como reporta Zélia Gattai:

Nas grandes festas, como, por exemplo, Natal, Ano-Novo, Páscoa, e nas datas cívicas italianas, eles [os moradores da rua Caetano Pinto e do Bixiga] recorriam à banda dos "Bersaglieri", composta de músicos fardados, ostentando vistoso chapéu de abas largas, um pedaço verde reluzente de plumas (parecendo rabo de galo) tombando sobre pescoço e ombro. Esses "Bersaglieri" eram contratados para tocar em frente às casas - quase sempre de italianos do Sul -, o concerto executado do lado de fora, na calçada. O repertório dos aparatosos soldados, composto sobretudo de antigas marchas militares, com o fascismo se ampliou, incluindo hinos modernos, cantos de glórias ao Dulce. ${ }^{83}$

A banda dos Bersaglieri, sediada no bairro do Bom Retiro e dirigida pelo maestro Giuseppe de Sicca, teve presença ativa no cotidiano da cidade, sobretudo durante as duas primeiras décadas do século XX. Em 1903, há o registro na grande imprensa de que seu nome completo seria Banda de Música Guido Mônaco-Bersaglieri. Contudo, foi com seu estilo (Bersaglieri, à semelhança de uma provável inspiração na original banda militar italiana) que essa corporação se tornou conhecida na vida cultural não apenas da colônia italiana, mas

${ }^{83}$ GATTAI, Zélia. Anarquistas graças a Deus. São Paulo: Companhia das Letras, 2009. p. 61. 
também da cidade, transformando-se em uma das referências da memória paulistana. Entre o final de agosto e início de setembro de 1969, a Banda Bersaglieri italiana promoveu apresentações musicais em São Paulo, quando, a convite da Secretaria de Turismo e Cultura do Município, visitou a cidade em um momento em que sua inspirada irmã paulistana já deixara de existir. No desfile de encerramento das comemorações de 7 de setembro daquele ano, a Bersaglieri tocou ao lado da Banda dos Granadeiros da Argentina e da Força Aérea do Uruguai, proporcionando ao público um memorável espetáculo, realizado no Vale do Anhangabaú.

A Banda do maestro Veríssimo apresenta certo enigma a ser decifrado ainda, já que há sobre ela, poucas fontes e informações. A grande imprensa e memorialistas fazem referência a ela com o nome próprio do maestro. Jacob Penteado, por exemplo, cita a participação da banda do "maestro Veríssimo Glória" abrilhantando os "retumbantes" bailes carnavalescos realizados no Teatro Colombo, no Largo da Concórdia, teatro esse inaugurado em 1908. ${ }^{84}$ A despeito do enigma referido acima, é possível afirmar que o maestro Veríssimo ilustra um certo trânsito que havia entre as bandas civis e as militares, pois sabe-se que ele foi regente não apenas da Banda de Música Recreio Artístico ou Recreio dos Artistas (1890), mas também da Banda de Música do $164^{\circ}$ Batalhão de Infantaria da Guarda Nacional (em 1902, agora já na condição de tenente maestro) e da Banda de Música do $9^{\circ}$ Batalhão de Infantaria da Guarda Nacional (1910). A propósito, é possível que ambas as bandas militares regidas por Veríssimo sejam a mesma, mudando-se apenas a designação numérica de sua Organização (de $164^{\circ}$ para $9^{\circ}$ ), em razão das constantes reestruturações internas pelas quais passaram as Unidades da Guarda Nacional. Também é provável que muitas das lembranças e indicações da imprensa sobre as bandas do "maestro Veríssimo Glória”, na verdade, sejam referências afetivas a essas bandas das quais o maestro era regente.

Reflexos claros do desenvolvimento da cidade e sua indústria, as ligações entre a música e o movimento operário estão estampadas nos próprios nomes das bandas apresentadas durante o período pesquisado. Vários desses nomes contêm o indicativo dessa vinculação entre o espaço cultural do incipiente universo urbano do trabalho e espaço cultural

\footnotetext{
${ }^{84}$ PENTEADO, Jacob. Belenzinho 1910: retrato de uma época. São Paulo: Martins, 1962. p. 16, 59-60 apud FONSECA, Denise Sella Uma "colcha de retalhos": a música em cena em São Paulo entre o final do século XIX e início do XX. 2014. Dissertação (Mestrado) - Faculdade de Filosofia, Letras e Ciências Humanas da Universidade de São Paulo, São Paulo. p. 34
} 
musical (ainda que se pensasse que música também não fosse trabalho!). Para se ter uma ideia, na Tabela 16 há pelo menos três bandas que apresentam em seus títulos a palavra Operária(os), o que agrega um significado de trabalho à música. Nesse caso, a música assumia um quase compromisso de representação de classe. Não apenas da classe operária, mas também da artística, dentro da qual, após o duro dia de trabalho na oficina ou na fábrica, o operário músico assumia a perspectiva artística e conseguia sair da alienação produzida pelo cotidiano e ingressar, ainda que por algumas horas, em uma outra atmosfera, onde encontrava voz, mesmo que fosse através de seu instrumento musical.

A música era o amálgama entre a dura vida operária que é carregada de cultura estrangeira. É o político representado por meio dos sons. Ideias e sonhos em busca de um pouco de justiça social. Nesse contexto, a representação de classe (artística) fala mais alto do que a realidade da fábrica. Embora banda não seja fábrica, dentro daquela havia espaço para aqueles que se identificassem como membros e partícipes do mesmo sonho e da mesma classe. O mesmo se dava no caso dos grupos de teatro social, conforme aponta Francisco Foot Hardman:

[...] No Brasil, já na primeira década deste século, surgirão principalmente no Estado de São Paulo e no Rio de Janeiro, dezenas de grupos anarcosindicalistas de teatro social, com representações sistemáticas anunciadas pela imprensa operária. Já que o sindicato se define, nessa corrente, “como a forma social do movimento revolucionário, destinada a substituir o Estado", ele deve constituir todo o universo do operário, preenchendo suas necessidades materiais, morais e culturais. ${ }^{85}$

As solenidades em comemoração ao $1^{\circ}$. de Maio, como préstitos envolvendo classes de trabalhadores ou manifestações sindicais, sempre contaram com a participação de bandas de música, ainda que estas não fossem dos próprios sindicatos, associações ou clubes operários mesmo que, por vezes, fosse necessário contratar-se uma banda para a prestação desse serviço. Contudo, o importante era haver música. Como o escopo desta pesquisa não é especificamente o movimento operário em si, selecionamos apenas uma corporação musical de caráter civil ligada à questão operária, na tentativa de demonstrar que as questões

\footnotetext{
${ }^{85}$ HARDMAN, Francisco Foot. Nem Pátria nem patrão. Vida operária e cultura anarquista no Brasil. 2. ed.
} São Paulo: Brasiliense, 1984. p. 44 
imigrante e operária (não necessariamente nessa ordem) influenciam fortemente o desenvolvimento da cultura urbana, e que, como fruto dessa cultura, as bandas de música foram uma de suas ferramentas de expressão. A banda civil que "roubou a cena" durante o início do século XX foi a Banda de Música União Operária da Lapa, fundada por volta de 1881. Para apresentar uma pequena ideia da importância atribuída às bandas pelo movimento operário e das tensões que influenciaram a existência dessas corporações musicais nesse contexto vejamos, algo que Francisco Foot Hardman discute:

[...] a música, como não poderia deixar de ser, esteve sempre na trajetória do movimento operário. Não como fator decorativo, externo, mas como elemento constitutivo do ritmo das manifestações, desenhando formalmente os contornos do ritual político e fazendo o contraponto exato ao discurso verbal - aspectos decisivos no andamento do clima e no encaminhamento simbólico da catarse.

Os exemplos são intermináveis. Pertencem a um mosaico internacional de compassos e acordes. No Brasil, em particular, a relação música/movimento operário se difunde por todo lado. Não só os grandes centros industriais registram essa influência, mas igualmente pequenas cidades do interior, capitais de regiões menores. Claro que o que restou são fragmentos. Sua pontilhação, entretanto, permite vislumbrar a um mundo que, apesar de definitivamente perdido, ecoa notas dispersas, caóticas, sobre a ordem aparente da história que se assentou depois. ${ }^{86}$

O início da Lyra da Lapa ou Corporação Musical Operária da Lapa, é atribuído pela tradição da própria Banda, ao imigrante italiano maestro e pianista Luigi Chiaffarelli (18561923). No entanto, conforme aponta Juliana Soares da Costa Silva, essa informação é incerta uma vez que Chiafarelli somente se estabeleceria em São Paulo em 1888 e a data de fundação daquela corporação musical estaria entre os anos de 1881 e 1882. Nomes como os maestros Paulo Chianato e Antonio Valeriani - dentre outros - também são apontados como condutores da Banda ${ }^{87}$. O nome da corporação, no entanto, mudou para Banda Musical 15 de Novembro após 1889, por motivos relacionados à representação pelas bandas do poder republicano. Ainda, conforme nos aponta Foot Hardman, no início do século XX, a corporação novamente mudou seu nome, em razão da maioria de seus componentes serem à época funcionários da

\footnotetext{
${ }^{86}$ HARDMAN, Francisco Foot. Lyra da Lapa: acorde imperfeito menor. Campinas, UNICAMP. In: Coleção Remate de Males $\mathrm{N}^{\circ}$ 5. 1984 p. 61-68.

${ }^{87}$ SILVA, Juliana Soares da Costa. Práticas musicais, comunidade, localidade e velhice: um estudo etnográfico sobre a Corporação musical operária da Lapa.2018. p. 43-44. Dissertação (Mestrado) - Instituto de Artes, Universidade Estadual de Campinas, Campinas.
} 
São Paulo Railway Company, para Banda de Empregados da S. P. R. É dessa fase (1910) um registro encontrado na grande imprensa atribuindo ao maestro Victor Arrigo a função de regente. Em 1914, a Banda trocava novamente de nome, passando a se chamar Corporação Operária da Lapa, nome com o qual finalmente se fixaria. Essa Banda deu origem, pelas mãos do maestro Valeriani (seu ex-integrante), à Banda da Vidraria Santa Marina, no bairro próximo à Água Branca, banda essa que, no entanto, sobreviveria por pouco tempo.

Nas memórias do contramestre da Corporação Operária da Lapa, Sr. Victor Barbiere, foram registradas apresentações da Banda nos mais diversos locais e ocasiões da cidade. Acompanhava clubes, como os Argonautas, Fenianos, Tenentes do Diabo, Democráticos, Carnavalesco Lapeano, Flor do Mel, Luz e Esperança, Grêmio da Lapa, $1^{\circ}$ de Maio Club, União Lapa e Rugerone, sendo considerada uma das melhores bandas civis da capital. Eventos religiosos também eram cobertos pela Banda, como as festas da Tabatinguera, Praça da Liberdade, Santa Cruz dos Enforcados, Santa Generosa e Largo Guanabara, além de inaugurações, como a pedra fundamental da Igreja da Freguesia do Ó, Matriz da Lapa, entre outras. ${ }^{88}$ Dessa forma, a União ou Corporação Operária da Lapa se tornaria uma das mais importantes corporações musicais de São Paulo e uma das provas vivas de resistência cultural coletiva operária, imigrante (no caso italiana), por meio dos acordes emitidos por seus instrumentos. Detentoras de práticas libertárias, bandas de operários tornaram-se imprescindíveis pelo livre exercício do lazer e pelas funções sociais que desempenharam no cotidiano das cidades e, mais ainda, na vida de seus componentes.

Com relação às bandas militares, é preciso antes de mais nada abordar a questão da representação do poder republicano e a ideia de "brasão sonoro". Em uma abordagem que Lilia Schwarcz ${ }^{89}$ faz sobre os símbolos e representações da Monarquia, a autora leva a compreender um pouco mais de perto as relações que certos símbolos desempenharam diante do poder. Partindo da ideia de que a Monarquia possuía, dentre seus símbolos, um "brasão sonoro" executado pelas bandas de música, ela afirma que seria essa uma tradução musical da identificação desse poder. Já o musicólogo Fernando Binder ${ }^{90}$ atribui essa qualidade,

\footnotetext{
${ }^{88}$ HARDMANN, Francisco Foot; Nem Pátria nem patrão: vida operária e cultura anarquista no Brasil. 2. ed. São Paulo: Brasiliense, 1984. p. 65.

${ }^{89}$ SCHWARCZ, Lilia Moritz. As barbas do Imperador: D. Pedro II, um monarca nos trópicos. 2. ed. São Paulo: Companhia das Letras. 2010. Passim.

${ }^{90}$ BINDER, Fernando Pereira. Bandas Militares no Brasil: difusão e organização entre 1808 e 1889 volumes I a III. 2006. Dissertação (Mestrado) - Instituto de Artes da Universidade Estadual Paulista, São Paulo. p.10.
} 
especificamente, às bandas militares. Defendemos no entanto, que o que se viu a partir da República pode ser entendido não mais como algo exclusivo dessas corporações militares, pois essa forma de representação e simbolismo, ou seja, o brasão sonoro republicano, tomou outras proporções, socializando-se musicalmente e alcançando não apenas as bandas militares, mas também as civis. Estas, de forma muito parecida e até mesmo na falta daquelas, prestaram as mesmas honras, tocaram continências, marcaram presenças e anunciaram autoridades à semelhança das corporações militares.

A esse respeito, cabe ressaltar que a partilha dessa representação era feita, de acordo com a esfera pública de poder à qual uma determinada banda pertencia, ou seja, autoridades políticas dos níveis federais geralmente eram saudadas por bandas do Exército Brasileiro ou da Guarda Nacional, uma vez que a cidade de São Paulo não registrou a presença de bandas de música da Marinha. Já as autoridades estaduais ficavam a cargo das bandas da Força Policial, depois Força Pública, que também atendiam às demandas do município de São Paulo e suas autoridades. Porém, nem sempre a regra era cumprida uma vez que não eram poucos os casos em que duas bandas militares se encontravam no mesmo serviço, ou seja, partiam para o mesmo destino, tendo por missão a recepção da mesma autoridade. Quando isso ocorria, prevalecia o bom senso entre os maestros para que o recepcionado ficasse o mais satisfeito possível. O mesmo ocorria entre bandas militares e civis em que, nesses casos, a precedência sempre era para as militares de forma protocolar, em razão da implícita representação do Estado por seus músicos, fardamento e insígnias. Bandas civis também se encontravam no mesmo serviço às vezes e, à semelhança das militares, traçavam acordos de última hora para que tudo ocorresse da melhor forma possível. Muitas vezes, fundiam-se em uma só banda para execuções de repertório comum entre elas e que, simultaneamente, atendesse às expectativas dos solicitantes.

Durante o período entre 1891 e 1930, as bandas militares encontradas foram: Banda de Música do $164^{\circ}$ Batalhão de Infantaria da Guarda Nacional ${ }^{91}$ (1902), ${ }^{92}$ Banda de Música da $66^{\text {a }}$ Brigada de Infantaria da Guarda Nacional (1902), Banda de Música do $2^{\circ}$ Batalhão da

\footnotetext{
${ }^{91}$ Embora a Guarda Nacional fosse uma Força paramilitar estabelecida através da Lei de 18 de agosto de 1831, várias de suas unidades criaram bandas de música que eram voluntariamente sustentadas pelos próprios membros da organização (oficiais). Muitos dos músicos eram apenas contratados sem, contudo, pertencerem à Guarda. Em 1922, a corporação foi definitivamente extinta.

${ }^{92}$ As datas entre parênteses indicam o ano em que as respectivas bandas foram citadas pelas fontes e não sua data de criação ou registro.
} 
Guarda Nacional (1906), Banda de Música do $9^{\circ}$ Batalhão de Infantaria da Guarda Nacional (1910), Banda de Música da Guarda Nacional do Braz (1903), Banda de Música do $17^{\circ}$ Batalhão de Infantaria do Exército (1888), Banda de Música do Corpo de Bombeiros (1895), Banda de Música do $7^{\circ}$ Batalhão de Voluntários Paulistas (1888), Banda de Música do $10^{\circ}$ Regimento de Cavalaria do Exército (1892), e Banda de Música da Força Policial de São Paulo (1889). ${ }^{93}$ Esta última, objeto central desta investigação, será abordada com mais atenção no capítulo 3, assim como ocorrerá com a Banda de Música da Guarda Civil do Estado de São Paulo (1926). ${ }^{94}$

Retornando aos primórdios da criação da Banda de Música da Força Pública, inicialmente denominada Banda de Música do Corpo de Policiais Permanentes ou Banda dos Permanentes", como ficou conhecida, vale lembrar que teve origem dentro da própria instituição policial criada em 1831, por ordem de Rafael Tobias de Aguiar, e abrigada no Convento do Carmo, a partir de 1832. Com a presença de alguns músicos, surgiu informalmente uma banda a partir de 1843, a qual só foi oficializada em 1857 pela Lei n. 24, aprovada pela então Assembleia Provincial. A partir da Guerra do Paraguai, a Banda permaneceu como efetivo de apoio, prestando serviços quando necessários às várias campanhas das quais a Guarda participou. Suas rotinas pautavam-se mais na vida castrense, relacionando-se pouco com a vida cotidiana da cidade. Denominada Força Pública pela Lei n. 97 A, de 21 de setembro de 1892, a instituição militarizou-se de forma mais contundente e a Banda ganhou um novo espaço junto ao Quartel da Luz na Avenida Tiradentes, projetado pelo arquiteto Ramos de Azevedo: uma sala ampla e bem arejada, com boa ventilação, própria para ensaios e guarda de seus instrumentos. Outras bandas foram criadas em outros batalhões, uma vez que, conforme a mesma Lei, a Força fora dividida em cinco batalhões de infantaria, um corpo de cavalaria e um corpo de bombeiros. ${ }^{95}$ É a partir desse momento que

\footnotetext{
${ }^{93}$ A Banda de Música da Força Policial ou Força Pública é a soma de um efetivo de músicos que ora se constituiu de uma, ora duas, ora de até três bandas simultaneamente, conforme será demonstrado no capítulo 3 . No entanto, para efeito de sistematização, foi adotado o critério de considerar-se apenas um conjunto (à exceção da Banda de Música do Corpo de Bombeiros), embora esse conjunto se desmembrasse em outros grupos simultaneamente.

${ }^{94}$ Conforme apontado em nota anterior, apesar do caráter civil da Guarda policial estadual fundada na gestão de Carlos de Campos em 1926, sua banda de música integra neste trabalho o grupo das militares em razão de suas características de formação e desenvolvimento.

${ }^{95}$ A mesma Lei cita ainda: uma banda de música e uma seção de enfermeiros; todavia, essa banda de música referida pela Lei era a que permanecia no $1^{\circ}$ Batalhão de Infantaria, não impedindo a criação de outras bandas nos demais batalhões, o que veio a ocorrer a partir de 1892 .
} 
ocorre a posse do alferes Joaquim Antão Fernandes na função de maestro e comandante da Banda ${ }^{96}$. Antão, promovido a alferes, ${ }^{97}$ em 15 de novembro de 1895 , realizou um concerto memorável para comemoração dos seis anos da República no dia de sua promoção, concentrando todas as bandas existentes da Força naquele momento ${ }^{98} \mathrm{e}$ logo esse maestro se tornaria uma das mais conhecidas referências no meio musical da cidade. A partir, portanto, dessa década, o nome Força Pública (que perduraria até a edição do Decreto n. 10.843, de 22 de dezembro de 1939), impôs à memória coletiva paulistana os eventos pelos quais essa banda ficou conhecida.

Portanto, é possível entender que a República estabelece mudanças na dinâmica da Banda. E vale ressaltar que tais mudanças não ocorreram especificamente nesse conjunto musical. De fato, toda a estrutura cultural da cidade passou a requisitar muito mais serviços desses corpos, em razão dos eventos que o ritmo de desenvolvimento impôs àquele momento. Obras constantes de remodelação geravam inaugurações, festas, banquetes para recepcionar autoridades visitantes (sobretudo estrangeiras), cerimônias protocolares e outros que, enfim, de forma implícita, empurraram a Banda para fora da caserna, obrigando-a a desenvolver e amadurecer um relacionamento com a sociedade civil, a qual, vendo na Banda a parte alegre e festiva da República, correspondeu a esse relacionamento, prestigiando sua presença em quase todos os eventos do regime progressista. Também sob a batuta de Antão, a partir da primeira década do século XX, a Banda entrou no universo das gravadoras. Sua discografia ainda é imprecisa, mas os levantamentos iniciais demonstram uma produção invejável de mais de 80 discos ao longo de sua trajetória, incluídos os 78 rpm, 45 rpm, LPs, Cds e também dois DVDs. Esses números referem-se ao período que vai de 1902 a 2019. No âmbito desta pesquisa, foi possível realizar um levantamento sobre a discografia da Banda da Força Pública durante o período de 1902 a 1932, conforme Tabela 19 - Anexo I. ${ }^{99}$

Por fazer parte de uma instituição cuja função primária estava pautada essencialmente na segurança pública, é preciso lembrar que a participação e o emprego dessa instituição nas

\footnotetext{
${ }^{96}$ Joaquim Antão Fernandes teve dois períodos de comando da Banda de Música da Força Pública, sendo o primeiro deles entre os anos de 1895-1925 e o segundo, 1931 e 1932.

${ }^{97}$ Cargo inicial da carreira de oficial da Força Pública até 1919. Atualmente sua equivalência é a patente de $2^{\circ}$ tenente.

${ }^{98}$ DELla MONICA, Laura. História da Banda de Música da Polícia Militar do Estado de São Paulo. 2. ed. São Paulo: Edanee, 1975. p. $42-43$

${ }^{99} \mathrm{O}$ resultado da pesquisa redundou em 38 faixas gravadas pela ODEON, e pela ZON-O-PHONE, em 38 discos de $78 \mathrm{rpm}$.
} 
diversas campanhas bélicas, nas quais se envolveu desde o início da República, ${ }^{100}$ desestabilizaram por várias vezes as atividades da Banda, tendo esta sentido de perto os reflexos das tensões políticas que se desenrolaram na vida da cidade, do estado e país. Uma vez que era prática comum da instituição o emprego de seus músicos em missões distintas das de instrumentistas, estes foram transformados em homens de pronto emprego para o enfrentamento dos manifestantes e grevistas (no caso de 1917) ou dos apoiadores do movimento tenentista junto a Miguel Costa (no caso de 1924). Desarticulada em julho daquele ano de 1924, retornaria às suas atividades dois meses depois, porém sob as mãos de um novo maestro - Benedicto de Assis Lorena -, em razão de Joaquim Antão Fernandes haver sido afastado de sua condução.

Lorena, maestro e compositor para teatro de revista, ${ }^{101}$ morreu precocemente em uma explosão dentro da sala de ensaios da Banda de Música do Primeiro Batalhão de Infantaria da Força Pública em 27 de maio de 1926, deixando um acervo de composições que muito contribuiu para a cultura e o universo musical paulistano. Salvador Chiarelli sucedeu-o e permaneceu até os últimos dias de 1930, quando os ventos da revolução Varguista trouxeram de volta o velho maestro Antão.

Como visto acima, o movimento de 1924 desarticulou de certa forma a Força Pública, a qual, a partir daquele mesmo ano, começou a organizar batalhões de guerra a fim de perseguirem a coluna de Miguel Costa que, no final de julho de 1924, seguira rumo a Oeste para encontrar-se com a coluna Prestes, que subia do Sul do país. Durante os anos de 1924, 1925 e 1926, grande parte desse efetivo da Força Pública foi empregado nos batalhões de guerra e nas campanhas no interior do país, contudo, como veremos no capítulo 3, a Banda de música apesar de sofrer indiretamente esses revezes, manteve-se relativamente preservada e em atuação. Para dar assistência médica aos familiares desses soldados que estavam em

\footnotetext{
${ }^{100}$ Durante o período entre 1889 e 1930, a Força Pública (incluindo sua Banda de Música), participou de forma direta ou indireta dos seguintes conflitos e movimentos sociais da Primeira República: Revolução Federalista e Revolta da Armada (1893-1894); Questão dos Protocolos (1896); Canudos (1897); Revolta da Vacina (1904); Revolta do Marinheiro João Cândido (1910); Greve Operária de São Paulo (1917); Os 18 do Forte de Copacabana e a Sedição de Mato Grosso (1922); Revolução de São Paulo (1924); Campanha de Goiás (perseguição à Coluna Miguel Costa Prestes) (1926); e Revolução Getulista de 1930.

${ }^{101}$ BESSA, Virgínia de Almeida. A cena musical paulistana: teatro musicado e canção popular na cidade de São Paulo (1914-1934). 2012. Tese (Doutorado) - Faculdade de Filosofia, Letras e Ciências Humanas, Universidade de São Paulo, São Paulo.
} 
campanha, longe da cidade, foi criada a Cruz Azul de São Paulo, ${ }^{102}$ cuja proposta principal era a construção de um hospital sem contar com verba pública. Nesse sentido, várias foram as colaborações da Banda de Música e, como reflexo do fenômeno musical criado nos Estados Unidos da América e cultivado pelo cenário urbano paulistano, viu-se, em 1927, a criação da Jazz Band da Cruz Azul de São Paulo. Idealizada pelas mãos do capitão e maestro Antônio Chiarelli (sucessor de Lorena), o grupo era composto por músicos pertencentes a outros grupos da Força Pública. Na verdade, tratava-se de uma "seleção de músicos" que compunham as bandas da Força Pública e que, uma vez escolhidos para compor o referido grupo, passaram a fazer parte dessa elite criada com a principal missão de promover o entretenimento de festas beneficentes para arrecadação de fundos para a construção do Hospital da Cruz Azul, bem como apresentações em salões e locais fechados, evitando-se as praças públicas e locais abertos. O estilo de repertório próprio para essa formação introduziu a música urbana estadunidense à Banda, mesclando ainda mais seu estilo e forma de interpretação das demais obras. Outro desdobramento da criação da Jazz Band foi a adaptação de obras ou temas para sua formação (por exemplo, o tema de "O Guarani” para Jazz Band) sob a forma de arranjos diversos, popularizando ainda mais a música de concerto.

A explosão da radiofonia, surgida nos anos 1920, tornou-se a grande mola propulsora e divulgadora da indústria fonográfica a partir dos anos 1930. ${ }^{103}$ Também tornou a Banda da Força Pública e sua Jazz Band cada vez mais próximas da população, e esta daquelas, criando laços artísticos e profissionais que desembocariam em participações e trabalhos conjuntos em todos os gêneros e espaços da cidade até hoje. A Banda da Força Pública e sua Jazz Band tomaram parte nesse tecido musical e sonoro da cidade de forma definitiva, pelo disco, rádio e, mais tarde, televisão. Sua história foi contada por Laura Della Mônica na obra História da Banda da Força Pública do Estado de São Paulo, publicada pela primeira vez em 1957 (quando de seu centenário) e reeditada em 1975. Apesar dessa narrativa e de a Banda habitar

\footnotetext{
${ }^{102}$ Criada em 1925, a Cruz Azul de São Paulo é uma entidade autárquica que tem por missão prestar assistência médica hospitalar aos membros da Força Pública. O Hospital da Cruz Azul de São Paulo foi construído com verbas oriundas de campanhas beneficentes da Força Pública, como provas turfísticas, loterias, chás beneficentes e apresentações da Jazz Band Cruz Azul de São Paulo, visto a autarquia não contar com verba pública para a obra. Em 1928, ocorreu a doação do terreno para a construção do Hospital, que se situa ainda hoje na Avenida Lins de Vasconcelos, 356, no bairro do Cambuci, em São Paulo. O Hospital presta assistência médica e ambulatorial aos dependentes de policiais militares do estado. Cf. ARRUDA, Luiz Eduardo Pesce de. Polícia Militar: uma crônica. A Força Policial, São Paulo, n. 13, p. 31-84, jan.-mar. 1997.

${ }^{103}$ MORAES, J. G. Vinci de. Metrópole em sinfonia: história, cultura e música popular na São Paulo dos anos 30. São Paulo: Estação Liberdade, 2000. p. 49-95.
} 
as crônicas e as lembranças de inúmeros memorialistas que viveram na São Paulo dos séculos XIX e XX, há ainda muito a se compreender sobre essa corporação e seu relacionamento com a cultura paulistana, conforme será tratado no capítulo 3.

Em suma, a cidade de São Paulo se tornou, durante o final do século XIX e as primeiras décadas do século XX, um campo fértil para o desenvolvimento de grupos musicais, especialmente para as bandas de música. Civis ou militares e em grande número, elas sonorizaram as ruas e prepararam os fundamentos para as atividades dos músicos populares. No entanto, para entendermos seus aspectos profissionais, é preciso conhecer melhor suas dinâmicas de trabalho e relações profissionais, o que faremos a seguir.

\section{A banda como trabalho}

Viver de música sempre foi um grande desafio para os profissionais de quaisquer grupos musicais. Manter tais grupos estruturados também. A lógica de um mercado em expansão, mas nem sempre favorável, no início do século XX dava um tom de grandes possibilidades a esses músicos, e criava ao mesmo tempo oportunidades de sobrevivência de seu ofício. Veremos a seguir as formas de financiamento e manutenção dos grupos e de seus músicos.

Com um número considerável de bandas, a cidade de São Paulo oferecia um vasto campo profissional aos músicos, que, muitas vezes, prestavam seus serviços em mais de uma corporação. Prática comum tanto entre os músicos militares quanto entre os civis, o fato de transitarem entre as bandas e demais grupos musicais da cidade oferecia-lhes a visibilidade necessária para serem cada vez mais chamados a tocar, sob a forma de contratos celebrados entre eles e seus empregadores, retroalimentando o circuito musical.

A contratação de músicos "convidados" para atuar em determinadas apresentações era comum nessa lógica quando o conjunto ou a banda não possuía profissional que a instrumentação exigia, recurso que até mesmo as bandas da Força Pública utilizavam. Em 1929, por exemplo, há o registro, no Boletim Geral n 164, sobre o pagamento de $30 \$ 000$ para um pianista que se apresentou com a Jazz Band da Cruz Azul no Theatro Santa Helena. $^{104}$

${ }^{104}$ Boletim Geral, Força Pública do Estado de São Paulo. São Paulo, n. 164, p. 1497, 16 jul. 1929. 
Aos domingos e feriados, era comum ocorrerem jornadas duplas, ou dobras de serviço, como se costumavam denominar duas apresentações no mesmo dia. As jornadas duplas acabavam gerando muito cansaço e um enorme tempo de emprego. Em artigo publicado em $O$ Estado de São Paulo, datado de 7 de junho de 1903, encontra-se uma crítica aberta à Banda Musical União Paulista, por parte dos músicos Norberto João Antunes Jorge, L. Vaz e O. Cruz, em razão da intensidade de trabalhos durante as festas de Santa Cruz da rua do Glicério, em que os músicos, reclamando da exaustão das tocatas, pediam um período maior de descanso. ${ }^{105}$ Entende-se também que, se há espaço para duas apresentações de bandas de música nesse período, há, consequentemente, demanda e consumo cultural para isso, o que revela a importância dada às corporações. Concertos com duração de 4 horas também são registrados pela grande imprensa, como é o caso de uma apresentação no Parque da Cantareira em 21 de maio de 1910:

Já está organisado o programma do grande concerto popular que se realisará amanhan, do meio-dia as 4 horas da tarde, no pittoresco parque da Cantareira, um dos mais attrahentes passeios da nossa capital, extraordinariamente bello e que, certamente se transformará agora num elegante centro de reuniões.

Como antecipamos, o tramway da Cantareira, na estação do Mercado, dará trens extraordinários de hora em hora, organisando outros, uma vez que seja avultada a concorrência.

A estrada de rodagem de Sant'Anna ao aprazível arrabalde, offerece livre transito para os automóveis e carruagens. ${ }^{106}$

Com relação à sua manutenção e de seus músicos, as bandas normalmente assinavam contratos com a Prefeitura Municipal para realizar uma sequência de apresentações ou concertos durante o mês. Findo o período, eram remuneradas conforme o referido contrato. O Estado de São Paulo de 8 de janeiro de 1903 traz uma nota indicando que a Banda de Música Italiana Ettore Fieramosca recebera a quantia de $960 \$ 000$, relativa aos concertos que executou no Jardim da Luz durante o mês de dezembro próximo passado. ${ }^{107} \mathrm{O}$ Correio Paulistano de 8 de maio de 1903, ${ }^{108}$ também apontava que haviam sido pagos $260 \$ 000$ para apresentação de uma banda durante a Exposição Agrícola, Pastoril e Industrial do Município

\footnotetext{
105 JORGE, Norberto João Antunes; VAZ, L; CRUZ, O. Festa de Santa Cruz da rua Glicério. O Estado de São Paulo, São Paulo, 7 jun. 1903. Secção Livre, p. 3.

${ }^{106}$ Concerto popular. O Estado de São Paulo, São Paulo, 21 mai. 1910. Notícias Diversas, p. 7.

${ }^{107}$ Notas e informações. O Estado de São Paulo, São Paulo, p. 2, 8 jan. 1903.

${ }^{108}$ FRANCO, A. Lacerda; BERLINK, Horácio. Correio Paulistano, 8 mai. 1903. Associações, p. 3.
} 
de São Paulo. Nesses casos, as verbas oriundas de contratos, quer fossem com Prefeituras quer com entidades particulares, entravam no caixa das associações via banda de música para serem utilizadas conforme a política financeira da própria entidade ou clube. Parte desse dinheiro era destinada aos músicos, como forma de pagamento mensal ou por jornada de serviço em concertos ou apresentações.

Contratos entre a Banda de Música da Força Pública e entidades, instituições, pessoas que a solicitavam e a própria prefeitura eram muito comuns. O Estado de São Paulo registrou a assinatura de um deles entre a prefeitura e o "governo" para que a Banda pudesse tocar no Jardim da Luz, três vezes por semana à tarde, às terças, quintas e domingos, além de dois concertos por mês à noite, pelos quais a Prefeitura pagou a quantia de 1:000\$000 (um conto de réis) por mês, durante 1903. ${ }^{109}$ Passados 22 anos, tal prática prosseguia, possivelmente não da mesma forma, mas, apesar de todos os problemas ocorridos nesse lapso temporal, em 1925, o Boletim Geral da Força Pública, $n^{\circ} 93,{ }^{110}$ de 27 de abril daquele ano, registrava outro contrato entre o maestro daquela Banda e o sr. Firmino Vieira de Camargo, contrato esse em que este a solicitava para tocar em uma festa, durante alguns dias, pela quantia de 1:200\$000. Outro Boletim Geral, o de no 131, ${ }^{111}$ de 13 de junho do mesmo ano, registrou uma verba no valor de 1:500\$000, recebida da Prefeitura pela mesma Banda de Música. Dessa forma, todos os meses as verbas arrecadadas eram recolhidas via caixa do Batalhão-Escola da Força Pública em razão dessas tocatas, sendo uma de suas finalidades o reforço ao pagamento dos músicos, o que servia para amortizar uma parte dos gastos com a folha de pagamento da Banda, uma vez que esses músicos já possuíam salários mensais pagos pelo Governo do Estado. Aqui, curiosamente, o dinheiro também era empregado para outra interessante finalidade: reforçar o sistema previdenciário da Caixa Beneficente da Força Pública do Estado de São Paulo. ${ }^{112}$ Na edição de 25 de janeiro de 1906, O Estado de São Paulo trouxe a seguinte nota quanto à arrecadação dessa Banda:

\footnotetext{
${ }^{109}$ Notas e informações. O Estado de São Paulo, São Paulo, p. 1, 12 jan. 1903.

${ }^{110}$ Boletim Geral, Força Pública do Estado de São Paulo. São Paulo, n. 93, p. 827, 27 abr. 1925,

111 Boletim Geral, Força Pública do Estado de São Paulo. São Paulo, n. 131, p. 1.118, 13 jun. 1925,

112 A Caixa Beneficente da Força Pública do Estado de São Paulo foi fundada em 1905 como uma entidade autárquica, criada pela Lei n. 958/1905, na gestão de Jorge Tibiriçá, cujo objetivo era o socorro de viúvas e órfãos da Força Pública e, dentre suas receitas, encontramos as verbas de arrecadações oriundas da prestação dos serviços da Banda de Música.
} 
No decorrer do anno findo, a caixa da banda de musica arrecadou proveniente de tocatas realisadas, mediante contrato, a quantia de 14:266\$598 réis, que com a de $330 \$ 070$ réis que passou por saldo anterior perfaz o total de 14:596\$668 réis.

No mesmo período, foram pagas por conta daquella verba, contas, no valor de 1:665\$300 réis, proveniente de compra de vários artigos destinados à mesma banda e consertos de instrumentos, bem assim a importância de 9:286\$618 réis de porcentagem aos músicos.

Foi recolhida ao thesouro a quantia de 2:730\$070 réis. Importando a despesa de 14:382\$188 réis para o exercício de 1906 o saldo de $214 \$ 180$ réis. ${ }^{113}$

Os Boletins Gerais da Força Pública revelaram que a dinâmica de arrecadação se dava mensalmente, conforme demonstrado acima, nos casos em que o pagador era o Thesouro Municipal. Quando o contrato era firmado com particulares, era normal a arrecadação dar-se em momento anterior à apresentação musical, sendo o ato discriminado no próprio contrato. A partir de 1925, pode-se ter uma boa percepção dessas arrecadações, uma vez que os Boletins traziam de tempos em tempos a publicação desses balancetes.

Os dados das Tabelas seguintes (2 a 7) apresentam individualmente valores pagos aos músicos (que, na verdade, eram praças da Força Pública) da Banda daquela instituição. As Tabelas tem como finalidade obter algum parâmetro sobre os valores percebidos, como salários entre 1898 e 1923, e demonstrar que estes eram menores, na média, que aqueles de outras categorias profissionais se comparados diretamente, conforme aponta Heloisa Fernandes: ${ }^{114}$

Tabela 2: Quadro comparativo de salários $-1898^{115}$

\begin{tabular}{|l|c|}
\hline \multicolumn{1}{|c|}{ Posto/emprego } & Salário Mensal \\
\hline Soldado (músico) & $105 \$ 000$ \\
\hline Carregador menor & $50 \$ 000$ \\
\hline Cozinheira nacional & $90 \$ 000$ \\
\hline Cozinheira estrangeira & $120 \$ 000$ \\
\hline
\end{tabular}

\footnotetext{
${ }^{113}$ Força Pública. O Estado de São Paulo, São Paulo, 25 jan. 1906. Noticias Diversas, p.3.

${ }^{114}$ FERNANDES, Heloisa Rodrigues. Política e segurança. São Paulo: Alfa-ômega, 1974. p. 226-31.

115 Os salários aqui apontados, representam profissões civis, comparadas à caserna.
} 
Tabela 3: Quadro comparativo de salários - 1902

\begin{tabular}{|l|c|}
\hline \multicolumn{1}{|c|}{ Posto/emprego } & Salário Mensal \\
\hline Soldado (músico) & $105 \$ 000$ \\
\hline Jardineiro & $80 \$ 000$ \\
\hline Cozinheiro & $120 \$ 000$ \\
\hline Cozinheira & $150 \$ 000$ \\
\hline
\end{tabular}

Tabela 4: Quadro comparativo de salários - 1906

\begin{tabular}{|l|c|}
\hline \multicolumn{1}{|c|}{ Posto/emprego } & Diária \\
\hline Soldado (músico) & $3 \$ 500$ \\
\hline Trabalhador de minas & $4 \$ 000$ \\
\hline Mineiro & $6 \$ 000$ \\
\hline
\end{tabular}

Tabela 5: Quadro comparativo de salários - 1911 e 1912

\begin{tabular}{|l|c|}
\hline \multicolumn{1}{|c|}{ Posto/emprego } & Salário Mensal \\
\hline Soldado (músico) & $102 \$ 000$ \\
\hline Foguista & De 100 a $150 \$ 000$ \\
\hline Maquinista & De 130 a $250 \$ 000$ \\
\hline Eletricista & De 210 a 250\$000 \\
\hline Condutor & $150 \$ 000$ \\
\hline Motorista (ônibus) & De 200 a 250\$000 \\
\hline Jardineiro & De 120 a $150 \$ 000$ \\
\hline
\end{tabular}

Tabela 6: Quadro comparativo de salários - 1914

\begin{tabular}{|l|c|}
\hline \multicolumn{1}{|c|}{ Posto/emprego } & Salário Mensal \\
\hline Soldado (músico) & $102 \$ 000$ \\
\hline Foguista & De 80 a $102 \$ 000$ \\
\hline Maquinista & De 130 a $250 \$ 000$ \\
\hline Eletricista & De 210 a $250 \$ 000$ \\
\hline Motorista (ônibus) & De 180 a $250 \$ 000$ \\
\hline Motorista (particular) & De 100 a $200 \$ 000$ \\
\hline Carroceiro & $90 \$ 000$ \\
\hline Jardineiro & De 70 a $100 \$ 000$ \\
\hline
\end{tabular}


Tabela 7: Quadro comparativo de salários - 1919 e 1923

\begin{tabular}{|l|c|c|c|c|}
\hline \multirow{2}{*}{ Posto e/ou emprego } & \multicolumn{2}{|c|}{1919} & \multicolumn{2}{c|}{1923} \\
\cline { 2 - 5 } & Máximo & Mínimo & Máximo & Mínimo \\
\hline Soldado (músico) & \multicolumn{2}{|c|}{$102 \$ 000$} & $300 \$ 000$ & $40 \$ 000$ \\
\hline Colonos & $150 \$ 000$ & $36 \$ 000$ & $300 \$ 000$ & $60 \$ 000$ \\
\hline Maquinista & $200 \$ 000$ & $60 \$ 000$ & $180 \$ 000$ & $40 \$ 000$ \\
\hline Camarada & $120 \$ 000$ & $40 \$ 000$ & $180 \$ 000$ & $45 \$ 000$ \\
\hline Carroceiro & $120 \$ 000$ & $40 \$ 000$ & $120 \$ 000$ & $45 \$ 000$ \\
\hline Colh. Algodão & $120 \$ 000$ & $50 \$ 000$ & $100 \$ 000$ & $20 \$ 000$ \\
\hline Cozinheiro & $100 \$ 000$ & $10 \$ 000$ & $80 \$ 000$ & $10 \$ 000$ \\
\hline Copeiro & $80 \$ 000$ & $10 \$ 000$ & $200 \$ 000$ & $70 \$ 000$ \\
\hline Motorista & $180 \$ 000$ & $50 \$ 000$ & & \\
\hline
\end{tabular}

De acordo com os dados das tabelas acima, é possível verificar que, na média, a posição do músico da Força Pública era mal remunerada se comparada a outras profissões urbanas. Dessa forma, era imprescindível que o músico encontrasse outras atividades em suas horas de folga, tocando em outros grupos da cidade, com a finalidade de complementar sua renda. No entanto, é importante ressaltar que, apesar do baixo salário, o ingresso nas bandas militares representava para o músico uma relativa segurança mensal, status impossível de ser alcançado nas bandas civis ${ }^{116}$.

Trabalhando muito, ganhando pouco e, muitas vezes, vendo-se obrigado ao exercício de uma outra profissão para o sustento pessoal e de sua família, o primeiro grande desafio era possuir sua ferramenta de trabalho, o que nem sempre era possível. Instrumentos musicais profissionais nunca foram baratos, sobretudo, se comparados ao salário recebido pelos músicos. Quando ocorria a formação de uma banda de música, havia a consequente necessidade de aquisição de uma variedade de instrumentos a fim de comporem, com sua diversidade, um conjunto apto à interpretação das obras escritas para uma banda regular. Aparentemente, o número variava entre um mínimo de 14 e máximo de 40 figuras. O conjunto era composto de madeiras (flautas, requintas e clarinetas - saxofones somente depois dos anos 1920), metais (trompetes, trombones, trombas, sax-honrs, bugles, sarrusofones e bombardões) além da percussão (bumbos, pratos, caixas claras, e tambores de todos os tamanhos).

\footnotetext{
116 Vale lembrar que entre os anos de 1912 e 1917, o piso salarial do músico da Banda da Força Pública, foi reajustado para o salário de Cabo de Esquadra (atualmente Cabo), minimizando um pouco essa questão.
} 
Nesse contexto de muito trabalho e pouca renda, a aquisição desses instrumentos e sua respectiva verba (no caso das bandas de estabelecimentos oficias como as militares e de prefeituras) era garantida por seu órgão criador através de dotação própria, geralmente votada pelo legislativo, ou por doação de alguma "ilustre personalidade" que, em um gesto de generosidade, doava o instrumental para compor o grupo. O Correio Paulistano de 3 de março de 1892 informa a criação de uma Banda de Música no 5 Corpo Militar de Polícia, a qual, por decisão de seu então comandante, coronel Machado, foi facilitada pela doação dos respectivos instrumentos musicais, que oferecidos pelo sr. Abílio Soares, foram adquiridos na Europa para uso dessa nova corporação musical. ${ }^{117}$ Associações quase sempre seguiam os mesmos rumos que o poder público no tocante às aquisições e posteriores empréstimos dos instrumentos para aprendizado e utilização dos músicos. Em 1890, a recém-criada Banda do Club dos Voluntários, presidida pelo capitão Lessa, também fez uma aquisição de um instrumental completo para o início das atividades, conforme informa o Correio Paulistano de 9 de julho de 1890, ${ }^{118}$ custeada pela respectiva associação.

Como se pode perceber, na maioria das vezes, o instrumento era cedido pelas corporações. Comprá-lo, portanto, não era coisa tão simples, e o músico precisava tocar muito para conseguir dinheiro suficiente para alcançar esse objetivo. Lojas não faltavam, uma vez que, a partir do final do século XIX (ainda como parte do desenvolvimento industrial e comercial pelo qual a cidade passou), várias delas instalaram-se oferecendo todos os tipos de instrumentos, assim como se iniciou a chegada das fábricas desse setor ${ }^{119}$. Em 1895, pelo Correio Paulistano, tem-se a notícia da instalação de uma dessas fábricas, oriunda de uma oficina de reparos de instrumentos musicais, pertencente a D'Aló \& Irmãos Zaccaria, com unidades em São Paulo e Rio de Janeiro, o que demonstra claramente haver um mercado consumidor já solidamente estabelecido para esse tipo de bem. ${ }^{120}$

Como se pode compreender, a sobrevivência através da arte musical, embora não fosse tarefa das mais fáceis, criou compartimentos profissionais dentro do universo musical estabelecido a partir do século XX na cidade. Transitando entre grupos musicais diferentes

\footnotetext{
${ }^{117}$ Nova banda de música. Correio Paulistano, São Paulo, p. 1, 3 mar. 1892.

118 Banda do Club dos Voluntários. Correio Paulistano, São Paulo, p. 1, 9 jul. 1890.

119 GONÇALVES, Janice. Música na cidade de São Paulo (1850-1900): o circuito da partitura. 1995. Dissertação (Mestrado) - Faculdade de Filosofia, Ciências Humanas e Letras, Universidade de São Paulo, São Paulo. Para as fabricas de instrumentos musicais, ver p.151-157.

${ }^{120}$ Fábrica de instrumentos de música. Correio Paulistano, São Paulo, p. 3, 19 mar. 1903.
} 
(bandas, orquestrinhas, conjuntos de câmara e tantos outros), os músicos viam-se obrigados a diversificar seu repertório para adquirir seus próprios instrumentos, manter-se ativos e empregados. Contendo um repertório próprio e característico, as bandas de música cumpriam aqui alguns importantes papéis socioculturais, como discutiremos a seguir.

\section{5. $\mathrm{O}$ repertório}

Assim como a língua está para a fala, o repertório de um determinado grupo musical está para sua identidade, pois esse repertório é uma das formas mais simples e práticas de construção da referida identidade. É através daquilo que o grupo toca que ele também se afirma. Dessa forma, poderíamos presumir que bandas tocavam músicas compostas exclusivamente para banda. Será? Para responder a essa questão, que, apesar de parecer tão simples, no fundo não é, foi necessária uma extensa pesquisa, que envolveu a grande imprensa e documentos oficiais, na busca das identidades das bandas, identidades essas que se revelaram mutantes - já que seu repertório também o foi - ao longo das três primeiras décadas do século XX.

Conhecer e compreender o repertório executado pelas bandas não é tarefa simples, pois a documentação é bastante precária, sobretudo a relativa às bandas civis. Como já foi destacado, a maioria delas estava relacionada a ou era sustentada por associações culturais ou de apoio mútuo. Apesar dessas evidentes relações culturais e musicais, os vestígios deixados por essas bandas ainda são rarefeitos, especialmente em relação ao repertório. Uma maneira de aproximar-se com mais clareza dele talvez seja tomar como referência as apresentações da Banda da Força Pública, em razão da boa disponibilidade de informações. A partir desse universo, pode-se inferir que um cenário sonoro geral das bandas paulistanas, estivesse dentro dos mesmos parâmetros uma vez também que a Banda da Força Pública, era uma das mais presentes e influentes. Lugar comum entre todos os programas de concertos e apresentações encontrados, era a evidência do predomínio de compositores estrangeiros, fato bem previsível para a época e, nesse conjunto, o desdobramento inevitável foi a poderosa presença dos compositores italianos.

Do universo de repertório, em 1903, a Banda executou muito mais obras dos italianos do que de qualquer outra nacionalidade, chegando o repertório italiano a um quarto do total, sem contar os possíveis "italianos não encontrados". Como indicam as Tabelas de repertório 
(Tabelas 8 a 15), os trechos de ópera tinham destaque. Por essa razão, certamente Verdi aparece em destaque, seguido por Ponchielli e Puccini.

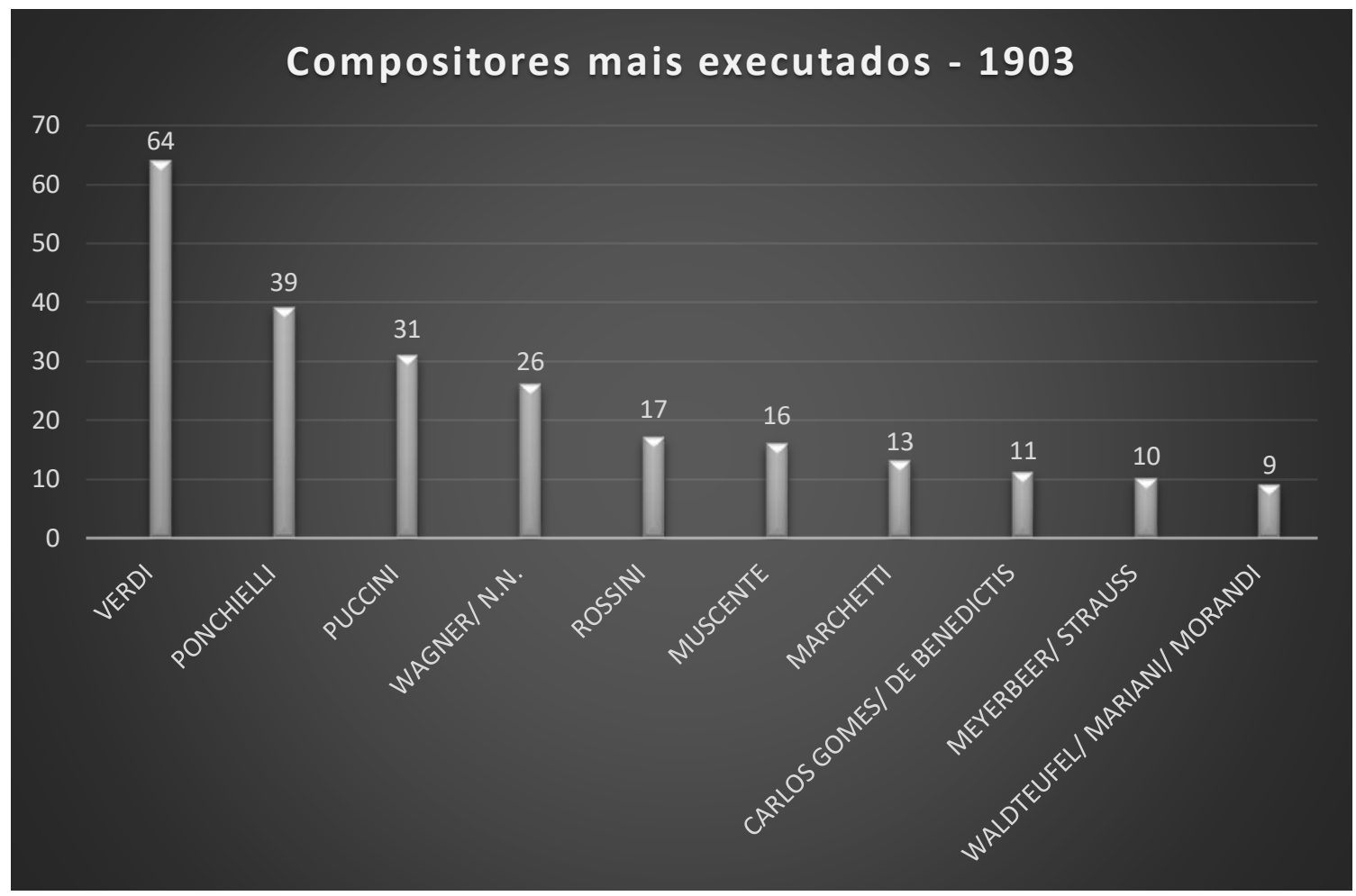

Figura 6.

Compositores mais executados durante o ano de 1903 pela Banda de Música da Força Pública em concertos. Indicadores produzidos com dados extraídos da Tabela 8 (ANEXO I).

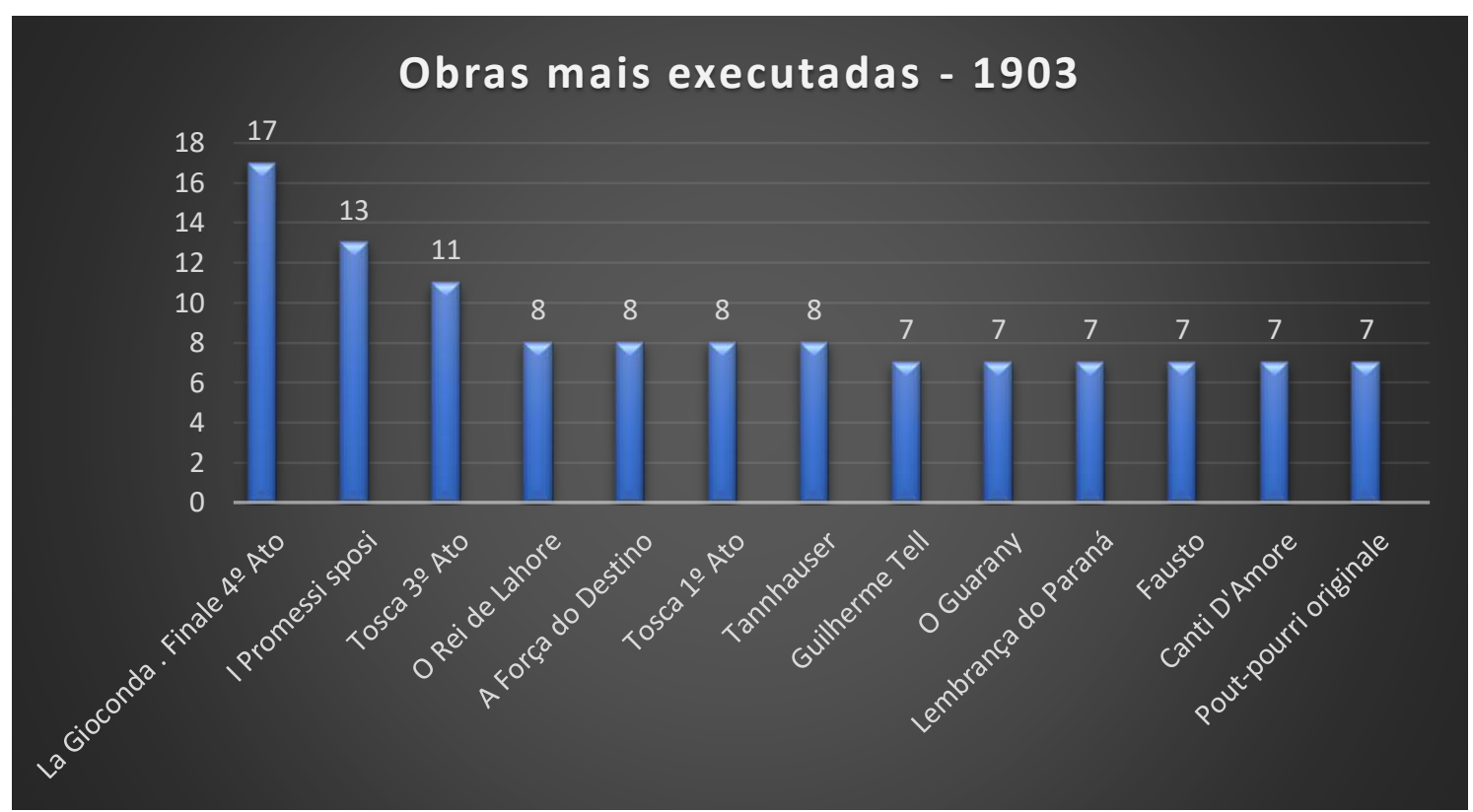


Figura 7.

Obras mais executadas durante o ano de 1903 pela Banda de Música da Força Pública em concertos. Indicadores produzidos com dados extraídos da Tabela 8 (ANEXO I).

A obra mais executada durante 1903 pela Banda de Música da Força foi o Finale IV ato da Ópera La Gioconda, do italiano Amilcare Ponchielli, aparecendo 17 vezes nos programas. Nada mal para um universo de 580 execuções em 78 apresentações distintas, mas o que pode chamar a atenção é o fato de que apenas três composições dentro das 13 listadas no gráfico acima não faziam parte do repertório operístico, sendo elas: a marcha Lembrança do Paraná (N.N.); a valsa Canti D’Amore (Vitelli) e outra valsa Pout-pourri originale (Nocentini). Novamente se fazem presentes a tradição e o peso da escola italiana pela ópera. Wagner, Strauss e os franceses, como Waldteufel, por exemplo, ainda deveriam esperar um pouco mais de tempo para atingirem o brilho italiano. Embora La Gioconda e Il Promessi sposi sejam compostas por Ponchielli e Tosca de autoria de Puccini, Verdi ocupa o lugar de compositor mais tocado naquele ano, visto que mais composições suas foram tocadas, o que gera, consequentemente, um maior número de execuções quando analisadas conjuntamente.

Finalmente, dentro desse universo de repertório de 1903, para a questão do gênero musical (e aqui nos damos a permissão de, mesmo com o distanciamento temporal, cometermos anacronismo em relação ao conceito de gênero no início do século XX), o que prevaleceu foi a ópera, conforme raciocínio apontado anteriormente, seguido do concerto. ${ }^{121}$ Isso confirma a hipótese de que as bandas exerceram a função de transposição do lugar social, trazendo a música do recinto público fechado (teatro) para o espaço público aberto, socializando o repertório de concerto executado dentro dos teatros e produzindo o gosto pela ópera e pelas demais formas musicais eruditas nas ruas, fazendo o caminho do público

\footnotetext{
${ }^{121}$ Para a compreensão do gênero concerto, foram englobadas as seguintes formas nesse conceito: fantasias, poemas sinfônicos, gavotas, aberturas, danças, cavatinas, comédias, suítes, sinfonias e seus movimentos, temas e variações e sonatas. Árias não são contempladas nessa classificação, pois o motivo que dá origem ao desenvolvimento da obra provém ou é englobado por outra forma maior - a ópera -, sendo a ária parte integrante dela. Neste caso, a classificação dada é a da forma maior, no caso, ópera. Estão inseridas nessa categoria também: operetas, oratórios, dramas líricos e óperas bufas e cômicas, italianas, francesas e alemãs, além de oratórios. É preciso, no entanto, esclarecer que os critérios adotados para as análises partem de um olhar contemporâneo, porém ao mesmo tempo retrógrado, em razão das fontes onde a valsa não é enquadrada como popular, nem a marcha (ainda que seja de carnaval ou militar). Como o objetivo deste item do capítulo é apenas apontar o que se tocava, uma análise mais detalhada poderá ser feita no futuro, reclassificando tais gêneros a partir de outras premissas e outro olhar, que não os adotados neste trabalho e neste momento, o que gerará consequentemente resultados diversos dos presentemente apurados.
} 
fechado para o público aberto, o que, na visão de Alberto Ikeda, ${ }^{122}$ tem uma relação direta de causa e efeito com a imigração italiana, em razão de ser essa comunidade, a maior divulgadora e apreciadora desse repertório de concerto. E vale lembrar que São Paulo possuía uma considerável colônia italiana.

Embora esse assunto seja melhor explorado no capítulo seguinte em "Circuitos do som”, dentre as demais peças, é possível compreender que polcas, mazurcas, dobrados, passo dobles e valsas representavam um repertório mais próximo do popular, típico das ruas e dos jardins e não dos teatros.

Observação importante a se fazer é o início da presença de autores brasileiros (como os Levy, Carlos Gomes e outros) entre os mais famosos nomes da música, tomando parte nos repertórios de apresentações das bandas a partir do início do século XX. Nos dados das Tabelas 8 a 15 (Anexo I), é possível perceber que tal fato se tornaria uma tendência ao longo do período pesquisado, uma vez que tais sistematizações cobrem o recorte de 1903, 1915, 1925, 1926, 1927, 1928, 1929 e 1930, quando a execução de música popular já se tornara novamente prática comum, tanto ao vivo quanto nas gravações em discos (o que também será tratado de forma mais complexa no capítulo 2, quando da abordagem da indústria fonográfica e seus efeitos sobre as bandas de música).

Voltando a 1903, do universo todo de composições, apenas cinco execuções de duas obras poderiam ser classificadas como populares, ${ }^{123}$ ainda que incorramos no risco do anacronismo por classificar como música de concerto ou popular, uma determinada obra que, para o paulistano naquele momento, poderia não possuir esse caráter, (conforme alertamos acima).

${ }^{122}$ IKEDA, Alberto T. Os italianos e a música em São Paulo. O Estado de São Paulo, São Paulo, 7 jan. 1989. Suplemento Cultura, ano VII, n. 442, p. 6

123 Trata-se das obras: Baile Excelsior (Pout-pourri), de Marenco, executada uma vez em 1903; e Samba Suite Brasilienne, de Alexandre Levy, executada quatro vezes em 1903 pela Banda da Força Pública. 


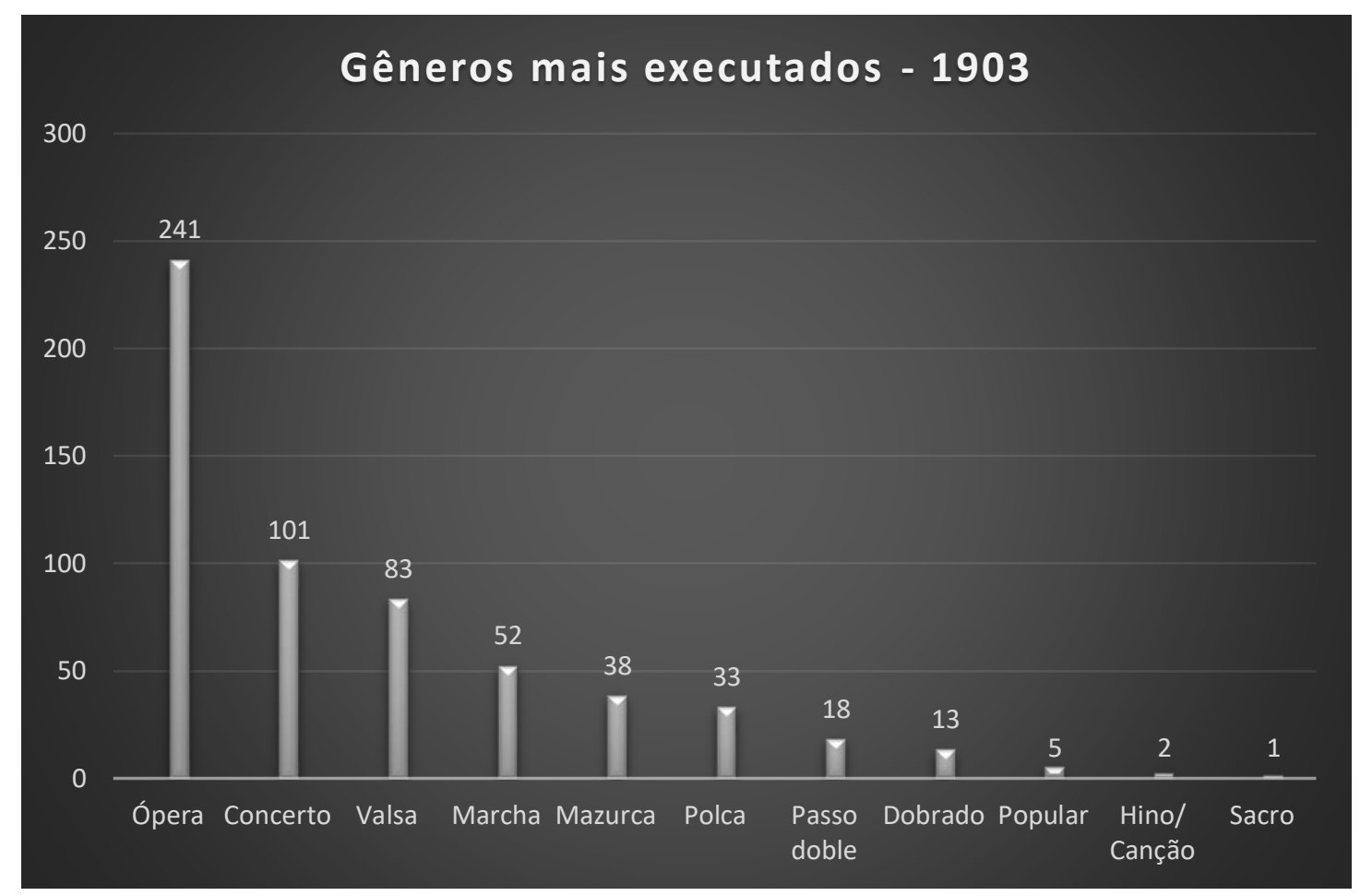

Figura 8.

Gêneros mais executados durante o ano de 1903 pela Banda de Música da Força Pública em concertos. Indicadores produzidos com dados extraídos da Tabela 8 (ANEXO I).

Os dados de 1915, dispostos na Tabela 9 (Anexo I), apontam para algumas mudanças. A principal delas trata da alteração do eixo de compositores mais executados, que anteriormente eram italianos, e passam a ser franceses, alemães e de outras nacionalidades. Nomes como Émile Waldteufel, Richard Wagner e Carl Teike surgem em primeiro plano a partir de 1915, desbancando os tradicionais italianos e suas óperas, como se verá à frente, no gráfico de gêneros (Figura 11). É possível que essas mudanças sejam reflexos de outras ocorridas internamente na Força Pública do Estado de São Paulo, a qual, a partir de 1906, recebeu a primeira Missão Militar Francesa, que teve por objetivo forjar um caráter mais militarista na instituição (assunto que será retomado em maior profundidade no capítulo 3). Liderada pelo Cel. Paul Balagny do Exército Francês, a Missão durou até 1914, quando, em função da Grande Guerra, retirou-se para retornar em 1919 e permanecer novamente até 1924. Nesse sentido, o período de 1915 tende a refletir algumas dessas influências europeias recebidas através da Missão Francesa, também por meio da música executada por sua Banda. A ascendência de compositores franceses, alemães e mesmo as marchas de Carl Teike, 
compositor polonês, podem representar uma época de transição no repertório da Banda da Força Pública a partir da segunda metade da década de 1910.

\section{Compositores mais executados - 1915}

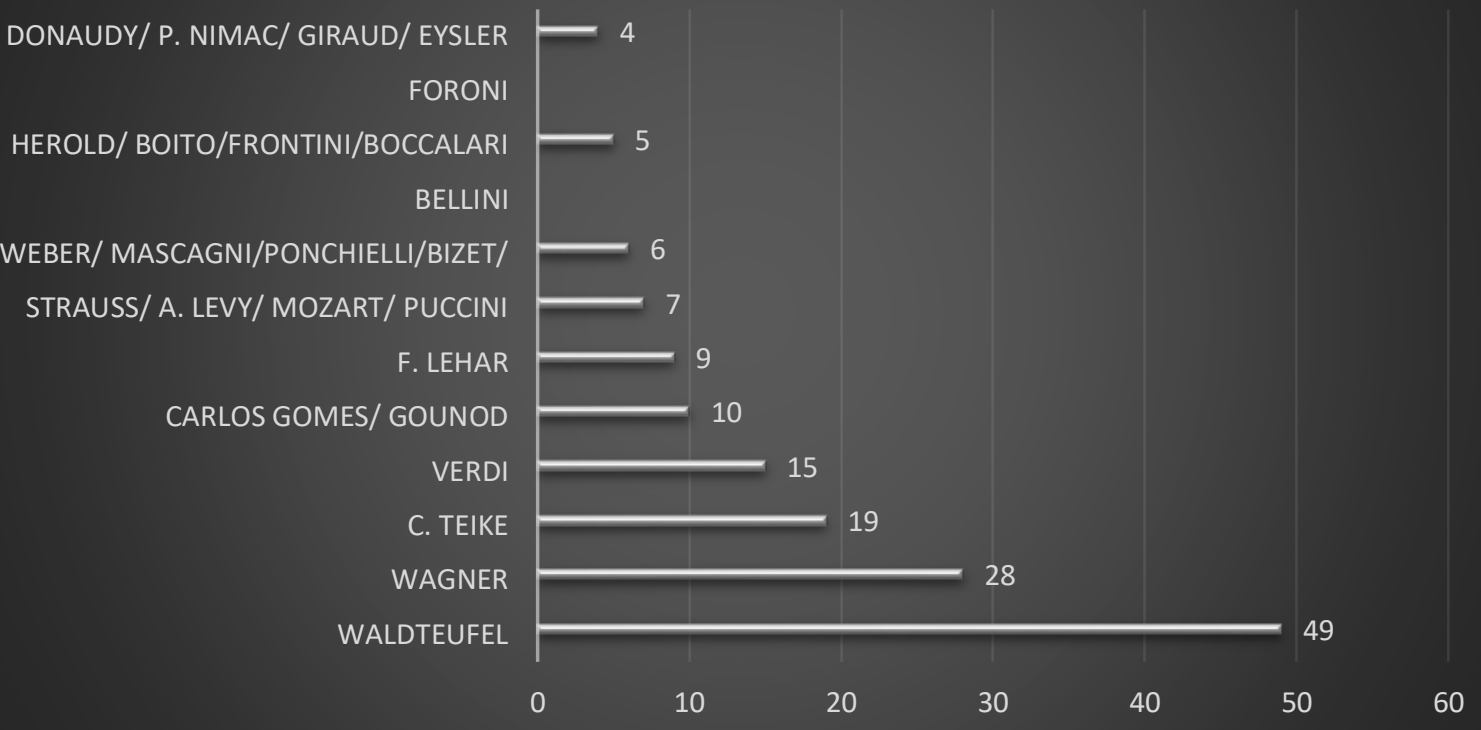

Figura 9.

Compositores mais executados durante o ano de 1915 pela Banda de Música da Força Pública em concertos. Indicadores produzidos com dados extraídos da Tabela 9 (Anexo I).

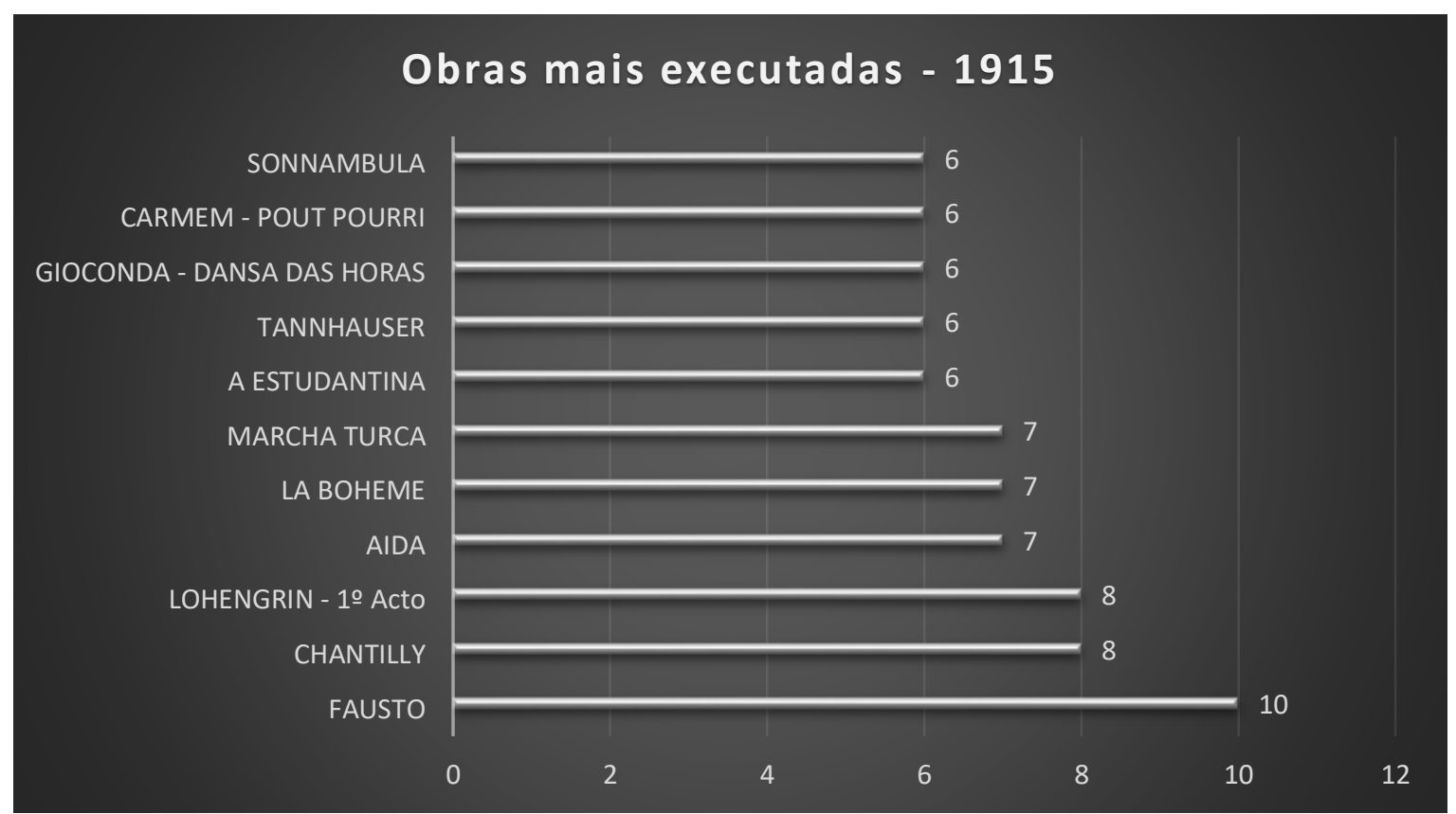

Figura 10.

Obras mais executadas durante o ano de 1915 pela Banda de Música da Força Pública em concertos. Indicadores produzidos com dados extraídos da Tabela 9 (Anexo I). 
Percebe-se uma melhor distribuição de execuções em termos numéricos entre as obras durante 1915. Fausto de Gounod foi a obra mais tocada com dez apresentações durante aquele ano, seguida de Chantilly de Waldteufel. Coincidência ou não, dois compositores franceses, provavelmente eram reflexo das mudanças trazidas pela Missão, como apontado anteriormente.

Quanto ao gênero, o que segue demonstra que em 1915 o concerto desbanca a ópera que aparecia em 1903 como primeiro colocado. As valsas ficam em segundo lugar enquanto as marchas aparecem como o terceiro gênero mais tocado. Deslocada para o quarto posto, a ópera já não se apresenta com tanta popularidade. Ao final da década seguinte como veremos, ela voltaria a reinar absoluta no gosto do público.

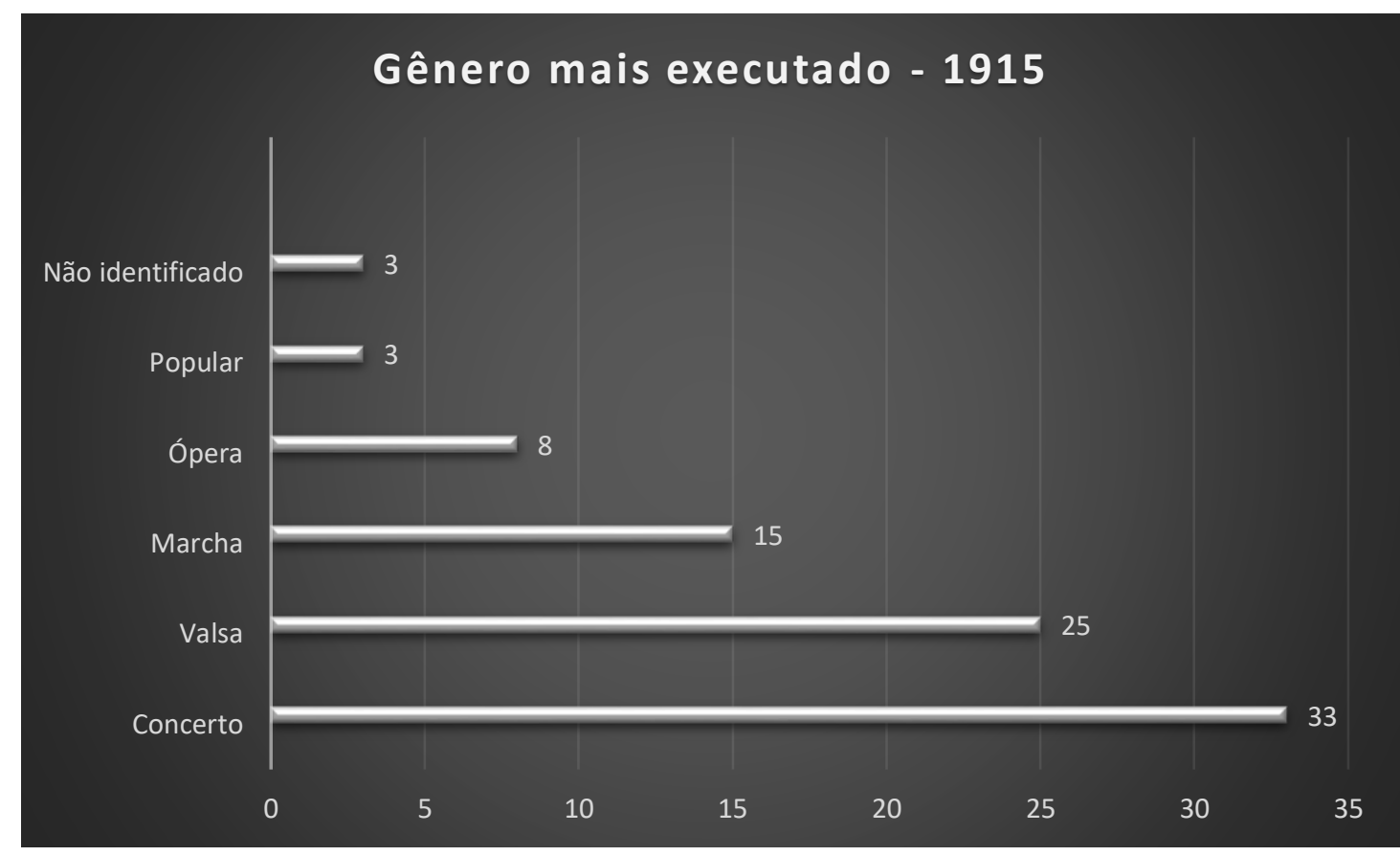

Figura 11.

Gêneros mais executados durante o ano de 1915 pela Banda de Música da Força Pública em concertos. Indicadores produzidos com dados extraídos da Tabela 9 (Anexo I).

Em síntese, os dados coletados e apresentados sobre os anos de 1903 e 1915 refletem uma tendência de mudança no repertório da Banda da Força Pública, a qual, como veremos à frente, não se confirmou ao longo da década seguinte. A ópera, na análise de 1925 a 1930, retornará ao posto de gênero mais executado; contudo, os compositores mais executados e as obras sofrerão mudanças. Isso é indício dos novos rumos do velho gosto de um público que 
já dispunha de relativo acesso a gramofones e discos, o que lhe possibilitava, dessa forma, escolher com certa facilidade o que ouvir e quando ouvir em um ambiente fechado, sem depender necessariamente da presença física de uma orquestra ou banda de música.

\section{Velhos gostos, novos rumos}

A década de 1920 acelerou a modernidade. A tecnologia, os automóveis, o cinema falado, a evolução da fotografia e a chegada do rádio ao Brasil criaram mais mudanças na paisagem cultural da cidade. $\mathrm{O}$ repertório e os grupos musicais também sofreram alterações como parte desse processo, como a criação das jazz bands, por exemplo. A música urbana se solidificou e o disco passou a cumprir o papel de seu principal divulgador para uma classe média cujo poder de compra passa a caminhar em conjunto a seu gosto de consumo. Nesse sentido, encontramos duas faces da mesma moeda ao analisarmos o repertório das bandas de música: a primeira delas é que essas bandas ainda permaneceram, durante a década de 1920, a cumprir seu papel de intermediadoras culturais; e a outra face é que o disco, na contramão dessa lógica, desconstruiria esse papel das bandas.

Decorridos 22 anos após o período da primeira e dez após o recorte da segunda sistematização de dados, o cenário encontrado em 1925 apresentava-se com a manutenção das mudanças já encontradas em 1915 no tocante à ópera não ser mais o gênero preferido da Banda da Força Pública. De acordo com a ideia já apontada da influência das missões francesas na Força Pública, havia uma possibilidade considerável de que o italiano Verdi perdesse o primeiro lugar no ranking das execuções de suas obras para algum compositor francês. No caso, foi Émille Waldteufel o compositor mais executado entre 1925 e 1930, com 59 execuções (somando-se o número de obras e vezes que foram executadas) de 19 obras; todas elas valsas. Waldteufel fez com que a Força Pública e sua Banda, influenciadas pela nova cultura, passassem a cultivar e executar mais a música francesa que as óperas italianas. ${ }^{124}$

\footnotetext{
${ }^{124}$ Esta afirmação, no entanto, se aplica apenas ao ano de 1925. Quando compilados os dados dos anos de 1925 a 1930, a ópera volta a prevalecer como veremos na figura 14.
} 


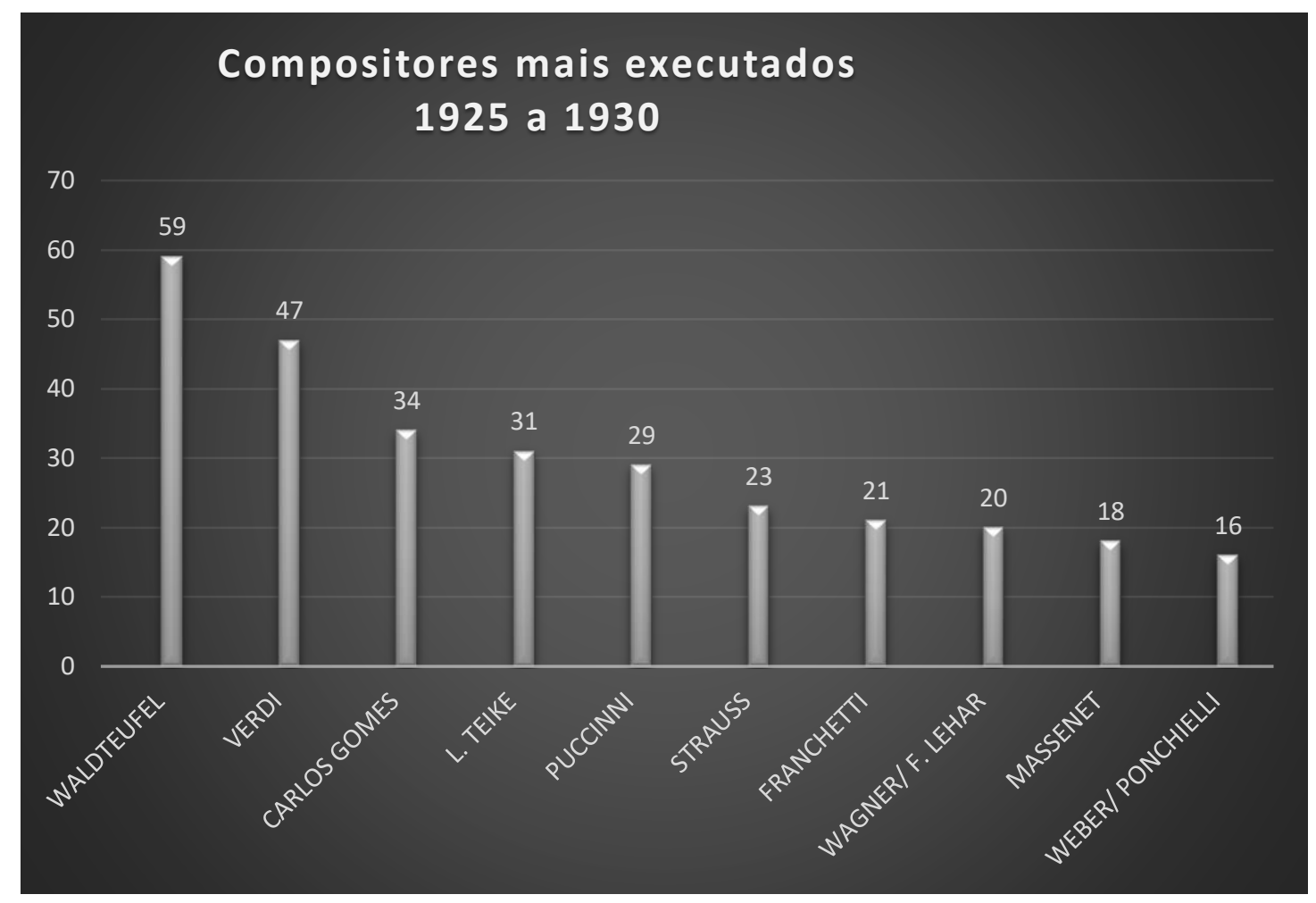

Figura 12.

Compositores mais executados durante os anos entre 1925 e 1930 pela Banda de Música da Força Pública em concertos. Indicadores produzidos com dados extraídos das Tabelas 10, 11, 12, 13, 14 e 15 (Anexo I).

Considerando que foram analisados 100 programas de concertos e apresentações, Waldteufel esteve presente em quase $61 \%$ deles, ou seja, a cada duas apresentações (um pouco mais de concerto sim, concerto não), havia uma obra sua sendo executada. Outra leitura poderá dar conta de que Carlos Gomes desponta em um terceiro majestoso lugar, tendo sido durante o período o responsável por nada menos do que 34 execuções dentro de todo o repertório. Mais um ponto importante a ser observado foi o declínio da escola italiana pelos diversos compositores nesse cenário, sendo substituídos por outros de nacionalidades diferentes (ainda que europeus). É importante ressaltar que, à semelhança de 1903 e 1915 , foram listados os dez compositores mais executados, dentro agora de um universo de 106 autores. No entanto, não se pode desprezar o fato de que os dados das Tabelas 8 e 10 são compostos de informações colhidas em um período de um ano, e o gráfico acima e os seguintes (Figuras 12, 13, 14 e 15) contêm dados compilados de seis anos de apresentações. 


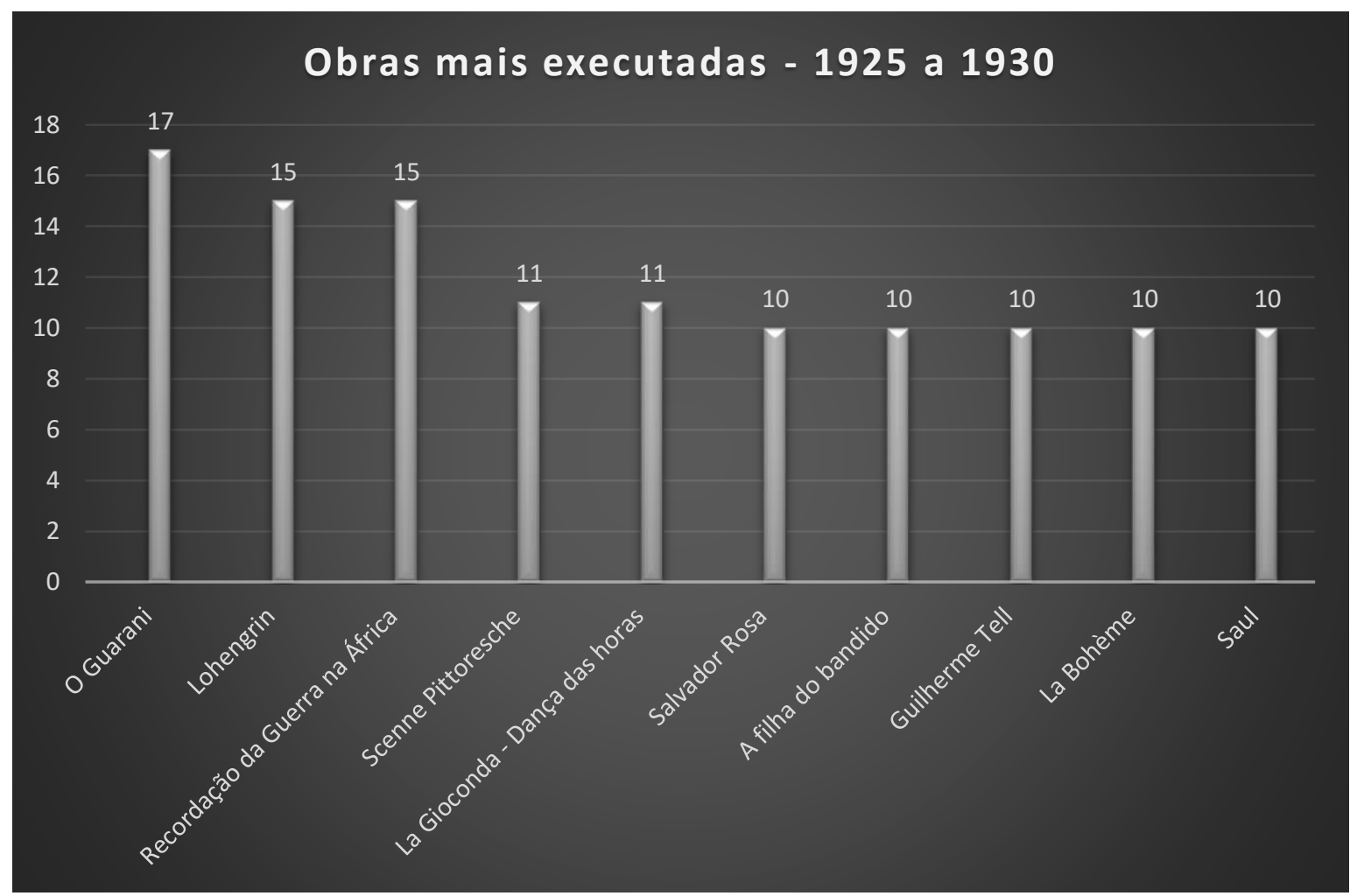

Figura 13.

Obras mais executadas entre 1925 e 1930 pela Banda de Música da Força Pública em concertos. Indicadores produzidos com dados extraídos das Tabelas 10, 11, 12, 13, 14 e 15 (Anexo I).

Nesse cenário, ainda se vislumbrou a prevalência de composições do ambiente operístico sobre as demais; isso será visto de modo mais claro a seguir (Figura 14), quando a questão de gênero for abordada.

Durante os anos de 1925-30, o gênero musical que prevaleceu voltou a ser a ópera, possivelmente como reflexo direto da formação do gosto por esse gênero, difundida e amplificada pelo comércio da indústria fonográfica. Os discos de orquestras comercializados, impunham o contato com esse repertório que era solicitado às bandas de música. A preferência mudou nos níveis composicionais, porém ainda era importante para as bandas manterem seus repertórios dominados pela "boa música" das salas de concertos, aproximando de forma direta dois mundos, o da banda e o da orquestra, pelo uso da mesma linguagem de execução. É interessante também notar que, na primeira sistematização (1903) dos programas de concerto da Banda da Força Pública, apresentados neste trabalho, os gêneros que se fazem presentes são: ópera, concerto, valsa, marcha, mazurca, polca, passo dobles, dobrado, popular, hinos e canções, além do sacro. Em 1915, tem-se então: concerto, 
valsa, marcha, ópera, popular, e não identificado o que demonstra uma certa tendência ao apagamento de mazurcas, polcas, hino/canção, dobrados e passo dobles, tendência que se consolidaria nas próximas amostras analisadas. Já na terceira sistematização (1925-30), a maioria desses gêneros prevaleceu, porém em menor número, apontando uma tendência de repertório mais para o popular (sobretudo marchas e valsas) do que para o de concerto e operístico, como se apresentava no início do século XX. Definitivamente, mazurcas, polcas e passo dobles desapareceram, passando-se a observar uma maior presença de compositores brasileiros. Concomitantemente a isso, outro fato curioso toma parte no cenário: a saída discreta e gradativa de cena dos compositores italianos, dentre as obras mais executadas.

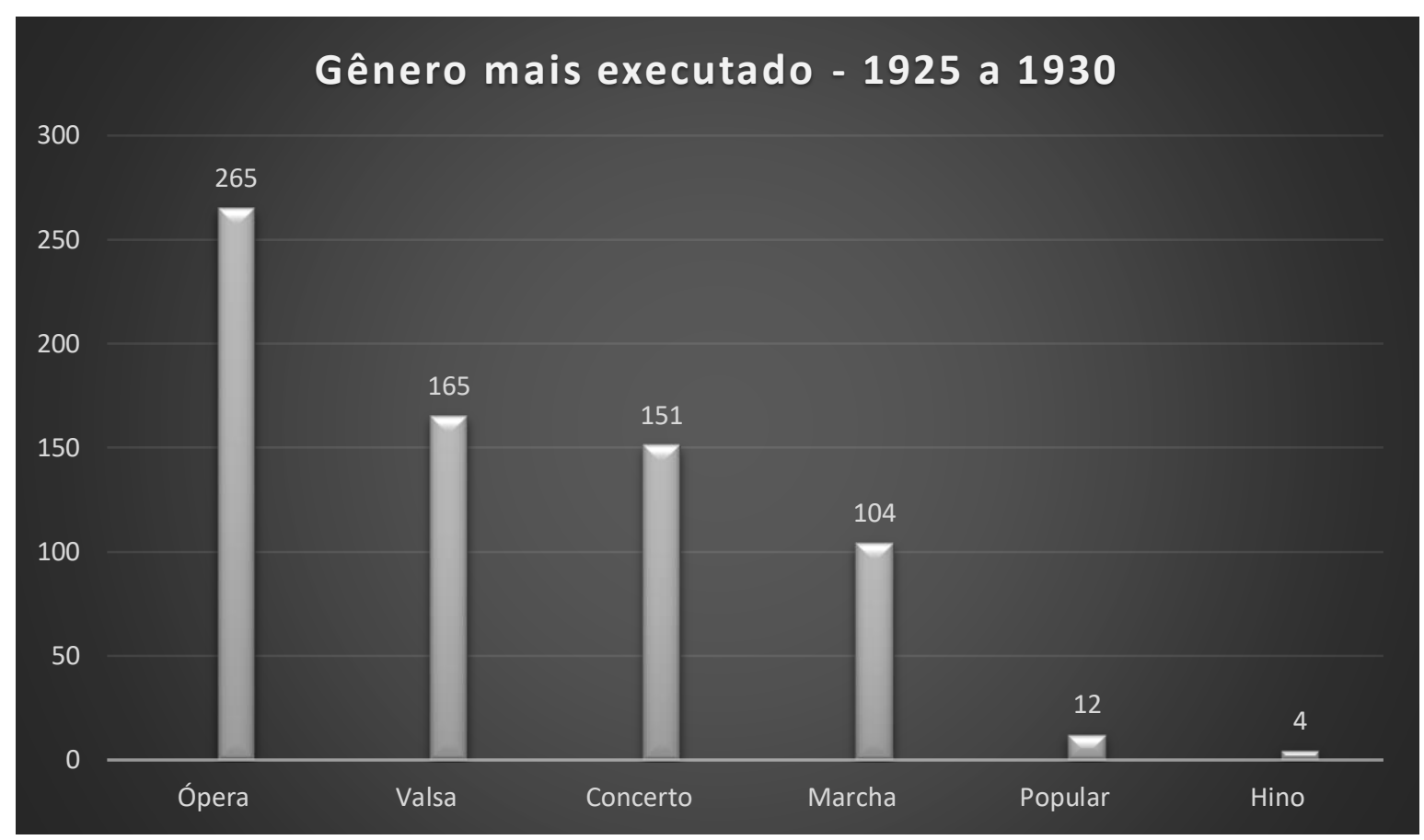

Figura 14.

Gêneros mais executados entre 1925 e 1930 pela Banda de Música da Força Pública em concertos. Indicadores produzidos com dados extraídos dos dados das Tabelas 10, 11, 12, 13, 14 e 15 (Anexo I).

Concluindo as análises de repertório, percebe-se que os indicadores não deixam dúvidas de que Verdi dominou as execuções em 1903 e Waldteufel prevaleceu em 1915 e no período 1925-1930. Todavia, Verdi manteve-se quase que nos mesmos níveis (pois foi o segundo compositor mais tocado na terceira sistematização), demonstrando uma constância 
própria dos clássicos que, pela sua característica de atemporalidade, são lembrados por gerações a fio. Uma leitura mais atenta pode também revelar uma mudança nos rumos do gosto do repertório, que aos poucos deixa os italianos para os palcos dos teatros e suas orquestras. Essa análise é corroborada pelos dados das Tabelas entre 8 e 15. A leitura pura e simples dos gráficos, comparando as obras e os gêneros mais executados entre os dois períodos analisados, não deixa muito clara a gradativa, mas tendencial popularização do repertório, enquanto um olhar mais próximo às tabelas pode esclarecer que, aos poucos, travou-se uma certa disputa no gosto do público ou dos intérpretes, popularizando-se o repertório; e os motivos para essa popularização podem ter sido muitos. Dentre eles, a indústria fonográfica, o início da radiofonia e possivelmente a miscigenação imigrante, a qual, entre 1920 e 1930, contava sua segunda geração em solo paulista. Nascidos em São Paulo, aos filhos dos imigrantes restavam tão somente as tradições. Estes não haviam nascido na Europa e estavam desprovidos dos laços emocionais que atavam seus pais ao velho continente. Eram, portanto, brasileiros e não mais italianos; porém, ao mesmo tempo, eram italianos e brasileiros dentro de um hibridismo cultural que permitiria a conservação, fusão e invenção de tradições nas palavras de Terence Ranger e Eric Hobsbawm. ${ }^{125}$ Aprendendo novos gostos, deixavam para trás o amor pelas árias de óperas e começam a se render ao Cake walk ou ao Two step e outras novas formas executadas pelas bandas.

Embora o Gráfico abaixo (Figura 15) demonstre um crescimento de execuções do gênero operístico nos anos 1925/30 em relação a 1903 e sobretudo 1915, é possível constatar com mais clareza o crescimento de execuções de valsas, marchas e música popular, refletindo a tendência apontada de popularização do repertório, detalhada anteriormente.

${ }^{125}$ RANGER, Terence O.; \& HOBSBAWM, Eric. J. A invenção das tradições. São Paulo: Paz e Terra, 2012. Passim. 


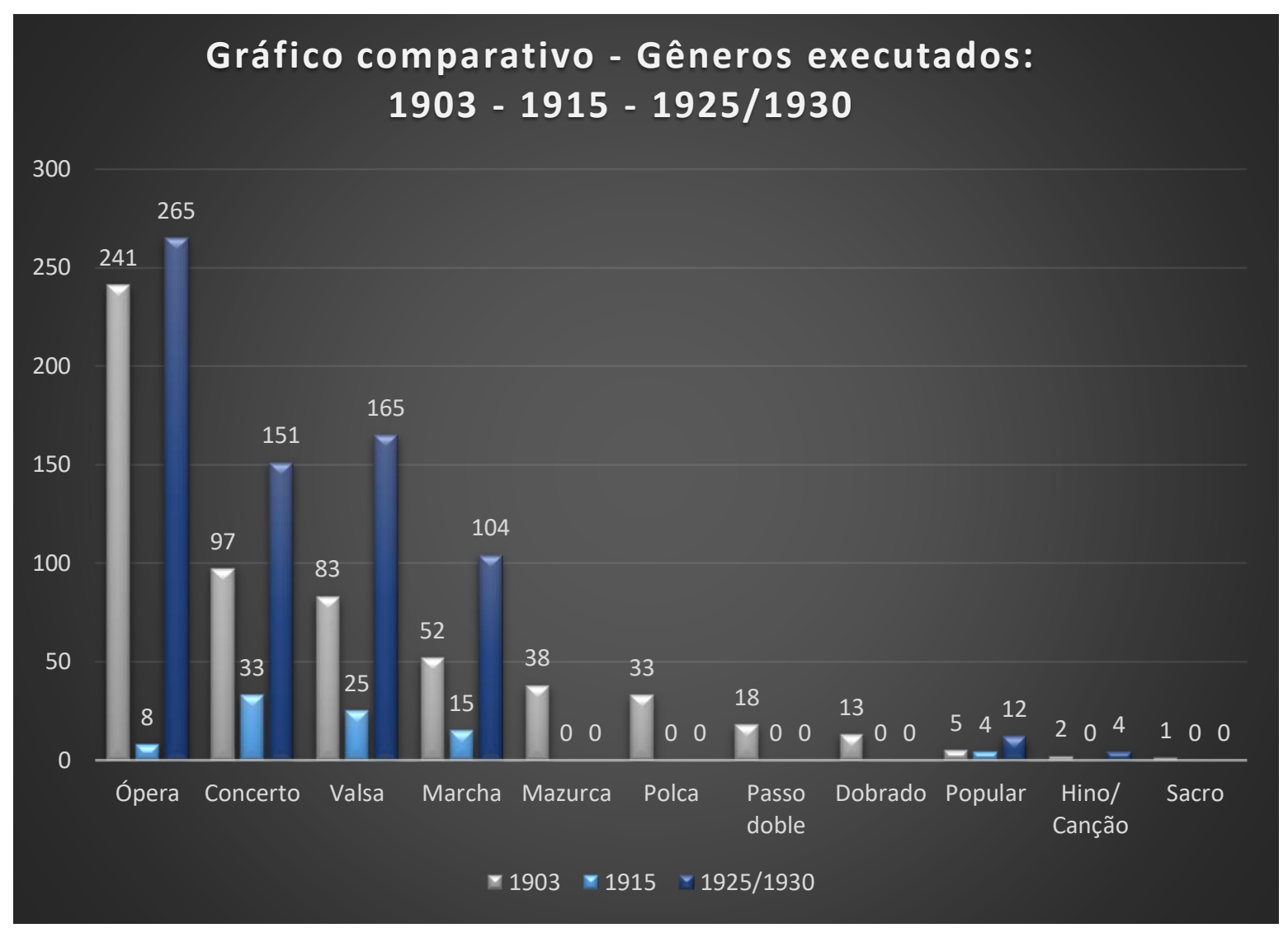

Figura 15.

Gráfico comparativo dos gêneros mais executados em 1903, 1915 e de 1925 a 1930 pela Banda de Música da Força Pública em concertos. Indicadores produzidos com dados extraídos das Tabelas 8 a 15 (Anexo I).

Um estudo sobre a nacionalidade dos compositores das obras executadas revelou que, em 1903, os dados apontaram para 26\% de italianos. A segunda sistematização já, em 1915, revelou praticamente uma continuidade das origens desses compositores, já que $24 \%$ deles ainda eram italianos, com ligeira alta percentual para alemães e franceses, austríacos e o surgimento de poloneses, tchecos, ingleses, dentre outros. Disso resultou que, das dez possibilidades de nacionalidades encontradas naquele momento, os italianos ainda prevaleciam. Já na terceira sistematização (que abrange o período entre 1925 e 1930), ocorreu um novo, porém discreto, aumento na execução dos compositores italianos, a qual chegou ao total de $28,29 \%$ das obras.

Por fim, o óbvio ficou claro: os números do repertório por nacionalidade de compositores demonstraram que, durante os três períodos pesquisados (a despeito de uma pequena queda em 1915), os compositores italianos dominaram o repertório dessa Banda durante as quatro primeiras décadas do século XX. Para a compreensão desses indicadores, 
é preciso uma reflexão sobre dois pontos cruciais no universo existente da música em São Paulo: primeiro, a imigração italiana, que, de uma maneira muito peculiar, trouxe em suas tradições a apreciação da ópera e influenciou aos poucos o gosto do paulistano por esse tipo de repertório; segundo, a formação de uma musicalidade em São Paulo, calcada e idealizada de uma perspectiva da escola musical italiana.

Essas condições acabariam por redundar na formação de gerações de músicos sob a influência dos grandes conservatórios musicais de Milão, Roma e Florença. Não por acaso, Carlos Gomes seguiu para estrear seu $O$ Guarani no Alla Scalla de Milão. Joaquim Antão Fernandes, maestro da banda da Força Pública, também para lá seguiu a fim de permanecer por um ano estudando as tramas da regência para conduzir sua banda. $\mathrm{O}$ mesmo fizeram muitos outros maestros e instrumentistas brasileiros, a exemplo de Henrique Oswald e Alberto Nepomuceno.

Em suma, é importante considerarem-se as relações entre as bandas de música civis e as sociedades de imigrantes (sobretudo italianas), como revelam as bandas Guido MônacoBersaglieri, Sociedade Ettore Fieramosca, Giuseppe Verdi, Giuseppe Garibaldi, Umberto I, Escola Italiana, Unione Meridionalle do Braz desse período e das próximas décadas, as quais receberam e forneceram músicos para outros grupos de formações mais simples ou complexas. Como visto neste capítulo, várias delas reuniram imigrantes (em especial italianos, portugueses, espanhóis e alemães) e se formaram a partir do último quartel do século XIX, resultado também do aumento do fluxo imigratório destinado ao trabalho em princípio nos campos das fazendas de café. É razoável ainda supor que vários imigrantes chegaram ao Brasil portando algum tipo de conhecimento musical ou pelo menos o gosto dominado pelo repertório de ópera. Trazendo novos instrumentos, os imigrantes adotaram a música como um de seus principais ramos de negócios na fabricação e comércio ou importação desses instrumentos, ensino e formação, direção e condução de grupos musicais ou nas editoras, conforme apontam Alberto Ikeda ${ }^{126}$ e Silvia Cristina Lambert Siriani ${ }^{127}$ e também como veremos no capítulo a seguir, quando será abordada a questão do ensino musical na São Paulo republicana.

\footnotetext{
${ }^{126}$ IKEDA, Alberto T. Os italianos e a música em São Paulo. O Estado de São Paulo, São Paulo, 7 jan. 1989. Suplemento Cultura, ano VII, n. 442, p. 6.

127 SIRIANI, Silvia Cristina Lambert. Uma São Paulo alemã: vida quotidiana dos imigrantes germânicos na região da capital (1827-1889). São Paulo: Imprensa Oficial do Estado, 2003. p. 314, 316, 322 e 323.
} 
Outro importante papel também cumprido pelas associações e pelo movimento imigratório seria o de manter os laços das tradições culturais entre o país de origem e o imigrado, que, longe de sua terra natal e sem as facilidades tecnológicas do século XXI, via no ambiente associativo o local ideal para encontrar patrícios, matar a saudade da culinária, das festas típicas, das roupas, do falar a língua pátria, dos jogos e brincadeiras e para ouvir e cantar as músicas de sua infância. Nesta terra, as bandas dessas associações cumpriram tal papel com maestria, transformando-se em verdadeiros suportes emocionais das colônias. Suas presenças passaram a ser imprescindíveis em todas as ocasiões possíveis a fim de manter esses laços emocionais e culturais atados apesar de um oceano de distância. Peças como a Marcha Real Italiana, as valsas, polcas e mazurcas de Strauss, passo dobles espanhóis, além de seus respectivos hinos nacionais, faziam a ponte sentimental entre a saudade e a dura realidade enfrentada no Brasil.

Como exemplos de festas associativas, O Estado de São Paulo de 12 de novembro de $1903^{128}$ trazia uma delas em comemoração ao aniversário do rei Victor Manuel III, que reuniu nada menos que 19 representantes de associações italianas das cidades de São Paulo, Campinas e Santos, tendo comparecido ao evento quatro bandas de música. ${ }^{129} \mathrm{Na}$ grande imprensa, encontram-se também inúmeras publicações sobre festividades levadas a cabo pela comunidade italiana na cidade de São Paulo, cujos objetos de comemoração nada têm de paulistano propriamente dito, o que é claramente entendido na transcrição que segue:

A colônia italiana commemorou hontem solemnemente a gloriosa data da unificação da Itália. Os festejos promovidos pela União Meridional Italiana constaram de alvorada, de uma passeiata pelo centro da cidade e, à noite de uma sessão magna e de fogos de artifício. [...]

[...] - O Círculo Umanitário Cruz Verde, precedido da fanfarra, fez também uma passeiata, cumprimentando a imprensa.

- Recebemos também cumprimentos da sociedade operária da Mooca e seu colégio que percorreram as principaes ruas da cidade com a banda musical Bersaglieri. ${ }^{130}$

Em outro artigo publicado no mesmo jornal em 2 de maio de 1910, vê-se uma festa organizada pela colônia italiana do estado (incluindo a da cidade) para a inauguração do

\footnotetext{
${ }^{128}$ Movimento associativo. O Estado de São Paulo, São Paulo, p. 2, 12 nov. 1903.

${ }^{129}$ As bandas citadas no artigo são: Umberto I, Bersaglieri, Unione Meridionalle do Braz e Unione Meridionalle do Bom Retiro.

${ }^{130}$ XX de setembro. O Estado de São Paulo, São Paulo, 21 set. 1903. Notícias Diversas, p.2.
} 
monumento a Giuseppe Garibaldi, que contou com a participação de nada menos que cerca de 4 mil pessoas. Conforme relatos da imprensa, o préstito foi composto por 51 entidades, incluindo associações, sociedades de socorros mútuos, sociedades de cultura italiana e demais agremiações culturais, oriundas de São Paulo e dos municípios do Estado, como Rio Claro, Campinas, Bragança, São Bernardo do Campo, Jundiaí e outros. Para puxar o desfile, oito bandas de música também mescladas entre as da capital e do interior do estado fizeramse presentes. Inicialmente, o cortejo concentrou-se na Praça da República e marchou até o Jardim da Luz, onde se deu a inauguração da estátua de Garibaldi. ${ }^{131}$

Dessas relações com a imigração e sobretudo das tradições culturais trazidas e preservadas pelos imigrantes, derivariam os repertórios compostos maciçamente por obras de autores europeus. Há que se considerar também que, quando brasileiros, esses compositores seriam em sua maioria, descendentes desses imigrantes, pelo menos, até o início da década de 1930.

As questões de formação dos músicos, dos tipos de grupos que fizeram parte do cenário musical da cidade e da influência da indústria fonográfica na vida das bandas de música são pontos importantes de observação, sem cujo mínimo entendimento, torna-se impossível compreender o universo musical do qual as bandas participaram nas primeiras décadas do século XX. Tais questões serão detalhadas no capítulo seguinte.

${ }^{131}$ Garibaldi. O Estado de São Paulo, São Paulo, p. 3, 2 mai. 1910. 
Capítulo 2

\section{Um panorama musical paulistano}


Em 24 de julho de 1892, o pintor Benedito Calixto convidou, por meio de notas nos jornais de grande circulação da cidade, ${ }^{132}$ seus amigos para a inauguração da tela $A$ innundação do Braz, ${ }^{133}$ um retrato eloquente das condições da região da Várzea do Carmo no final do século XIX. Eventos dessa natureza eram publicados comumente na imprensa da época. O convite pelos jornais provavelmente tinha intenção de dar publicidade ao acontecimento e garantir público, ao mesmo tempo que dava certa noção de prestígio ao fato. Nesse caso, as personalidades previstas para a inauguração da tela foram o Vice-Presidente do Estado, além de Secretários, o que indicava o prestígio do pintor. O local escolhido foi o Theatro Minerva, respeitada casa de espetáculos frequentada pela elite paulistana. Para acompanhar o evento, foi convocada a Banda de Música do Corpo de Permanentes, que tocou durante a exposição. O caráter oficial da Banda, seu prestígio à época e a força sonora que continha provavelmente deram à inauguração importância e relevo maior. Conforme vimos no capítulo anterior, esse tipo de prática que associava a música aos eventos públicos era comum em São Paulo durante a Primeira República, atraindo público para as mais diversas finalidades. Na verdade, as bandas de música eram apenas um dos muitos tipos de conjuntos musicais que povoavam os espaços públicos e privados da cidade naquele momento. Assim como bandas de música contendo 15 e 30 figuras, grupos instrumentais como pequenas orquestras, conjuntos de câmara, bandas de carnaval e outros tipos ocupavam as ruas e os teatros paulistanos do início do século XX, reverberando de forma concreta características de um tempo e modo próprio de uma prática musical, conforme veremos a seguir. A historiografia sobre o tema ainda não conseguiu dar as respostas a algumas questões básicas como quais eram as formações mais usuais, que tipo de instrumentistas compunham esses grupos musicais, qual a formação deles, como e onde trabalhavam e assim por diante. O objetivo deste capítulo é justamente penetrar um pouco neste rico, mas ainda obscuro, universo musical.

\footnotetext{
${ }^{132}$ A innundação do Braz. O Estado de São Paulo, São Paulo, p. 2, 24 jul. 1892.

${ }^{133} \mathrm{O}$ título correto da tela é Innundação da Várzea do Carmo, que hoje é patrimônio do Museu Paulista da Universidade de São Paulo. Paisagem resultante da observação direta do autor através de uma janela lateral do prédio que pertencia ao Palácio do Governo situado no espaço que abriga o atual Páteo do Colégio, o pintor registrou a várzea do Carmo (atual Parque D. Pedro II) em um momento de inundação que a cidade sofreu em março de 1892. As informações constantes na nota foram transcritas de acordo com suas apresentações nas fontes originais.
} 


\section{Grupos e pequenas orquestras}

Longe da Corte, faltava na vida musical da cidade oitocentista quase tudo, de professores e instrumentos a locais para apresentações. Assim, tudo indica que o problema central, entre o final do século XIX e a primeira década do XX, resumia-se em dois pontos: a formação musical demasiadamente precária, quase inexistente, que não dava condições para formatação desses grupos musicais; e as condições financeiras e manutenção dos agrupamentos musicais. Nesse período, o poder público precário, certamente permaneceu distante do universo musical.

Durante todo o século XIX, a existência em São Paulo de conjuntos musicais e orquestras estáveis foi rara, porém, conforme aponta Camila Carrazcosa Bomfim, a partir de 1874 a cidade presenciou sua primeira temporada de óperas e concertos. ${ }^{134}$ Apareceram nessa época inúmeras orquestras e conjuntos eventuais de vida efêmera. Havia os casos dos grupos vinculados a algum teatro, como a orquestra do antigo Teatro São José, cuja existência foi relatada por Antônio Egydio Martins ${ }^{135}$ em 1877, mas que logo depois desapareceu. Mais comuns eram os grupos formados por uma companhia teatral, por professores ou então associações. As companhias de teatro musicado que visitavam a cidade, por exemplo, traziam a parte central de suas orquestras e recrutavam aqui apenas uma parcela de músicos. Associações musicais e recreativas também se instalam com a finalidade de buscar a formação de corpos estáveis a partir do último quartel do século XIX, transformando-se em fundamentos para as futuras orquestras surgidas na primeira metade do século XX. ${ }^{136}$ Nesse momento, surgiram apenas algumas iniciativas privadas, como a fundação em 1888 da Sociedade Paulista de Música, que pretendia também resolver essas questões básicas de formação e manutenção. Em 1903, o Jornal Correio Paulistano anunciava a apresentação da

\footnotetext{
${ }^{134}$ BOMFIM, Camila Carrazcosa. A música orquestral, a metrópole e o mercado de trabalho: o declínio das orquestras profissionais subsidiadas por organismos públicos na região metropolitana de São Paulo de 2000 $a$ 2016. 2017. Tese (Doutorado) - Instituto de Artes da Universidade Estadual Paulista, São Paulo. p.108.

${ }^{135}$ MARTINS, Antônio Egydio. São Paulo antigo: 1554 a 1910. São Paulo: Paz e Terra, 2003. p. 235.

136 Para uma compreensão mais aprofundada sobre o assunto, ler: Bases políticas e ideológicas da estatização de orquestras na cidade de São Paulo In: BOMFIM, Camila Carrazcosa. A música orquestral, a metrópole e o mercado de trabalho: o declínio das orquestras profissionais subsidiadas por organismos públicos na região metropolitana de São Paulo de 2000 a 2016. 2017. Tese (Doutorado) - Instituto de Artes da Universidade Estadual Paulista, São Paulo. p.93-179.
} 
Orchestra Paulista sob a direção de Alonso da Fonseca, Alberto Borba e do maestro Luiz Chiaffarelli. O jornal destacou que:

Por todo este mez teremos occasião de ouvir um bello concerto, cujo programa, composto exclusivamente de musica clássica, já entrou em ensaios.

Será esta a primeira audição musical que nos proporcionará a Orchestra Paulista, a qual já conta com 42 professores dentre os melhores do nosso meio.

Devemos a reunião destes excelentes elementos aos srs. dr. Alonso da Fonseca, Alberto Borba e Luiz Chiaffarelli, que acabam de tomar a si a direcção da Orchestra Paulista.

Parabéns aos iniciadores de tão elevada idea e ao publico de S. Paulo, que, finalmente possuirá um centro musical digno do seu celebrado gosto artístico. ${ }^{137}$

Não se tratava da composição de um corpo estável de músicos, já que a ideia era reunir 42 professores para que, havendo necessidade, os concertos pudessem ser executados. No mesmo ano, na edição de 10 de maio, na seção "Factos diversos", o jornal trouxe a nota de que a Sociedade Beneficente Orchestral Paulista, regida pelo maestro Antônio Leal, realizaria seu concerto de estreia no bosque do Parque Antárctica, começando às 3 horas em ponto. A Light fez correr bondes extraordinários para que a população do centro da cidade pudesse se deslocar até o lugar do evento e apreciar o concerto, cujo programa extenso continha obras de Strauss, Gillet e Wagner, ${ }^{138}$ além de outros autores, incluindo a suíte Caso Colonial de Carlos de Campos. ${ }^{139}$ As apresentações da orquestra sucederam-se durante o ano de 1903, porém aos poucos o grupo foi deixando a cena musical paulistana e as páginas dos jornais.

Resumidamente, no decorrer da primeira metade do século XX, a Sociedade de Cultura Artística, a Sociedade de Concertos Symphonicos, o Centro Musical de São Paulo, e a Sociedade Phylarmonia, tenderiam a mudar as condições e status dos grupos musicais de efêmeros para estáveis; situação que começou a se consolidar de forma definitiva somente

\footnotetext{
${ }^{137}$ Orchestra paulista. Correio Paulistano, São Paulo, 1 maio 1903. Platéas e Salões, p. 3.

138 Parque Antárctica. Correio Paulistano, São Paulo, 10 mai. 1903. Factos diversos, p. 3.

${ }^{139}$ Carlos de Campos (6 agosto 1866 a 27 abril 1927) foi político e advogado, $12^{\circ}$ Presidente do Estado de São Paulo entre o $1^{\circ}$ maio 1924 e 27 abril 1927. Por também possuir aptidão para a música (compositor e instrumentista), teve algumas de suas composições executadas pelos diversos grupos que permearam a vida cultural paulistana. Em sua homenagem, o Conservatório Estadual de Música, sediado na cidade de Tatuí, leva seu nome.
} 
com a formação do Departamento de Cultura da cidade de São Paulo, em 1934, e o comando de Mário de Andrade.

Geralmente, as festas populares apresentavam seus grupos eventuais, que duravam apenas o ciclo das festividades. O carnaval, certamente, era o período em que elas apareciam em quantidade, proporcionando ao músico um momento para faturar dinheiro extra. Chamados tradicionalmente de bandas de carnaval, charangas ou mesmo de orquestras, esses conjuntos tinham por missão alegrar bailes carnavalescos em salões, ou puxar desfiles pelas ruas, entretendo blocos que animadamente percorriam a cidade. No carnaval de 1903, por exemplo, O Estado de São Paulo, anunciava "Uma banda de música, montada, composta de 80 figuras, vestindo todos a pegadores a unha, com as competentes carapuças vermelhas, faixas e jaquetinhas". ${ }^{140} \mathrm{O}$ grupo provavelmente fora formado apenas para os festejos, como era comum naquele momento dentro do meio musical. Impressionante era o número de componentes: 80. Levando-se em conta que a média de efetivo das corporações era 20 músicos, pode-se cogitar a possibilidade de quatro grupos reunidos em um, a fim de atender à demanda de serviços gerada pelo carnaval. Já em pleno carnaval de 1912, o mesmo jornal noticiava que, em um tradicional baile à fantasia no Teatro Polytheama, apresentava-se uma Orchestra de Senhoritas e magnífica banda de música, evento pelo qual se deveria pagar a quantia de $26 \$ 000$ (vinte e seis mil réis) pelas frisas, 15\$000 (quinze mil réis) pelos camarotes e 5\$000 (cinco mil réis) pelo ingresso simples, sendo o Café Guarany, localizado na rua 15 de novembro, o local de aquisição desses bilhetes. ${ }^{141}$

As pequenas orquestras de cinema eram muito comuns. Tocavam durante a exibição das fitas mudas e nos saguões ou antessalas de exibição. Alguns cinemas, em razão dos custos gerados pelos conjuntos, substituíram-nos por pianistas que, a partir de então, ficavam encarregados da execução completa do evento, ou seja, desde a entrada até a despedida (incluindo, é claro, a trilha sonora da fita). Zélia Gattai comenta sobre esse universo musical dos cinemas no início do século XX:

O cinema representava o ponto alto da nossa programação semanal. Próximo à nossa casa, único do bairro, o "Cinema América" oferecia todas

\footnotetext{
${ }^{140}$ Democráticos Carnavalescos: Carnaval de 1903. Annuncios. O Estado de São Paulo, São Paulo, 24 fev. 1903.

${ }^{141}$ Polytheama. O Estado de São Paulo, São Paulo, 11 fev. 1912. Annuncios, p.11.
} 
as quintas-feiras uma "soirée das moças", cobrando às senhoras e senhoritas apenas meia-entrada. [...]

O conjunto musical que acompanhava a exibição dos filmes compunha-se de três figuras: piano, violino e flauta. Ano entra, ano sai, o repertório dos músicos era sempre o mesmo. Os primeiros acordes do piano, do violino ou da flauta anunciavam ao público o gênero da fita a começar. Ninguém se enganava $\left[\ldots . .{ }^{142}\right.$

Jorge Americano também descreve, em suas memórias, o ambiente sonoro dos cinemas:

Para amenizar a fita há sempre um terceto, quarteto ou quinteto musical, cujos componentes incorporavam-se mais tarde aos conjuntos de rádio, ou às orquestras típicas. [...] O intervalo entre cada uma das partes [do filme] era mais longo ou mais curto conforme a diligência do portador, e as vicissitudes do tráfego.

De vez em quando os cinemas dão "shows" nos intervalos.

Numas dessas fitas, "O barqueiro do Volga", um dos intervalos foi preenchido com um "show", em que, ao som da música, passavam os barqueiros ao natural cantando e puxando a corda pesada, em passos tardos. ${ }^{143}$

O autor terminava sua observação narrando que, "naquele tempo", falava-se já na possibilidade da combinação do cinema com a vitrola, a qual, inserida nas possibilidades tecnológicas da modernidade, ajudaria o cinema mudo a encerrar suas atividades a partir de 1927, ano em que The Jazz Singer, de Alan Crosland, usando o sistema sonoro Vitaphone ${ }^{144}$ da Warner Bros foi lançado. Encerrava-se, assim, a contratação de músicos para o acompanhamento dos filmes. Aos poucos, esses profissionais foram obrigados a procurar emprego em outros grupos para sobreviver.

Em síntese, as orquestras como as entendemos hoje somente apareceriam após a década de 1930; os grupos de câmara eram restritos a ambientes fechados e os jazz bands somente apareceram na terceira década do século XX. Antes disso, os únicos grupos que se dispunham a levar música aos recintos públicos abertos da cidade eram as bandas de música.

\footnotetext{
${ }^{142}$ GATTAI, Zélia. Anarquistas graças a Deus. São Paulo: Companhia das Letras, 2009. p. 12-13.

${ }^{143}$ AMERICANO, Jorge. São Paulo nesse tempo (1915-1935). São Paulo: Melhoramentos, 1962. p. 245-246.

144 Conhecido como o primeiro método de sonorização bem-sucedido, o sistema Vitaphone consistia na gravação de um disco fonográfico eletronicamente vinculado à projeção do filme de forma sincronizada.
} 


\subsection{Outras bandas}

Embora o capítulo anterior tenha apresentado uma primeira discussão sobre as corporações musicais paulistanas, há ainda necessidade de aprofundamento. Inicialmente talvez seja interessante explicitar o conceito de bandas de música como grupos estruturados sobre uma instrumentação basicamente delimitada por três seções distintas - metais, madeiras e percussão - diferente da orquestra, que recebe além desses o naipe das cordas. Essa estrutura, guardadas as devidas substituições ou inclusões de instrumentos pelo advento de tecnologias, estabeleceu-se nesses padrões desde o período colonial. Em São Paulo, há registros da época colonial que indicam que cerimônias, solenidades e festas religiosas eram acompanhadas por essas formações, conforme aponta Antônio Egydio Martins. ${ }^{145}$ Mas, conforme vimos antes, com a chegada da Família Real portuguesa ao Rio de Janeiro em 1808, as atividades das bandas, sobretudo as marciais, multiplicaram-se. Contudo, além da faceta da banda enquanto grupo instrumental, há outras no âmbito das relações sociais, que devem ser discutidas. Para José Geraldo Vinci de Moraes, as bandas formavam uma espécie de elo entre o mundo dos salões, das ruas e praças, já que seus integrantes percorriam esses espaços e transitavam pelo universo musical da cidade, intercambiando conhecimento e cultura, tanto no espaço privado quanto no público. ${ }^{146}$

Perfil semelhante àquele da Banda da Força Pública teve a do Corpo de Bombeiros do Estado de São Paulo. Criado em março de 1880, após um danoso incêndio na Biblioteca da Faculdade de Direito do Largo de São Francisco, o Corpo de Bombeiros instituiu sua Banda de Música em $1^{\circ}$ de janeiro de $1895 .{ }^{147}$ Após sua criação, a Banda realizou várias apresentações, sem muita projeção ${ }^{148}$ e teve vida efêmera. A troca de instrumentistas entre as duas corporações parece ter sido comum, incluindo o maestro da Banda dos Bombeiros, que, em 1899, migrou para a da Força Pública. ${ }^{149}$ Ao que parece, a Banda foi extinta entre os

145 MARTINS, Antônio Egydio. São Paulo antigo. 1554 a 1910. Paulo: Paz e Terra, 2003. p. 235.

${ }^{146}$ MORAES, José Geraldo Vinci de. Arranjos e timbres da música em São Paulo. In: PORTA, Paula (Org.). História da cidade de São Paulo. São Paulo: Paz e Terra, 2004. vol. 1. p. 598.

${ }^{147}$ Almanach histórico e literário de São Paulo, São Paulo, 01 Jan 1895 p. 321. Dirceu Jair Mellone, no entanto, afirma que a criação da Banda do Corpo de Bombeiros é datada de 1891, contendo um efetivo de 25 músicos. MELlONE, Dirceu Jair. Corpo musical. Arte e profissão. Monografia apresentada ao Curso de Aperfeiçoamento de Oficiais-I/86 (CAO), São Paulo: PMESP, 1986, p. 17.

${ }^{148}$ MILANO, Miguel. Os fantasmas da São Paulo antiga. São Paulo: Ed. UNESP, 2012. p.111.

${ }^{149}$ Houve uma estreita relação entre esse conjunto e o da Força Pública, uma vez que seu maestro, Salvador Chiarelli, aceitando um convite feito por aquela instituição em 1899, fora transferido para lá, chegando a exercer as funções de seu comandante entre os anos de 1926 a 1931 após a morte de Benedicto de Assis Lorena. 
anos de 1896 e $1897,{ }^{150}$ mas, do mesmo modo que suas pares, também teve papel importante na profissionalização do músico popular.

Inúmeros são os registros na grande imprensa sobre as corporações musicais oriundas de comunidades de imigrantes. Em 10 de abril de 1889, A Província de São Paulo noticiava que a Banda de Música Italiana, dirigida pelo professor José Máximo, aceitava “chamados” para bailes, casamentos, etc., e deixava para a devida contratação o endereço Rua da Conceição n. 4 A, São Paulo ${ }^{151}$. Conforme dito antes, o dinheiro arrecadado nas apresentações tinha por destino o suprimento do caixa desses grupos e o restante, geralmente, era rateado entre os músicos, como forma de pagamento. Dependendo de outras circunstâncias, como o contratante e número de músicos para o rateio, esse dinheiro poderia chegar a uma boa soma. Em 8 de janeiro de 1903, uma matéria publicada em $O$ Estado de São Paulo acusava um valor de $960 \$ 000$ (novecentos e sessenta mil réis) pagos à corporação Ettore Fieramosca por concertos realizados no Jardim da Luz em dezembro de 1902, ${ }^{152}$ perfazendo uma média de $120 \$ 000$ (cento e vinte mil réis) por apresentação. Descontados os valores aproximados de $20 \%$ para custos operacionais do grupo, sobraram $768 \$ 000$ (setecentos e sessenta e oito mil réis), os quais, divididos por uma média de 20 músicos, poderiam gerar $38 \$ 400$ (trinta e oito mil e quatrocentos réis) por músico; valor significativo, considerando-se que a diária de um soldado músico da Força Pública era 3\$500 (três mil e quinhentos réis). ${ }^{153}$ Leilões também eram uma forma de renda para as bandas. Em 16 de agosto de 1890, o Correio Paulistano recebera um convite:

\section{CONVITE.}

Recebemos um convite do Club Musical Riachuelo para assistirmos a um leilão de prendas em benefficio do hospital de lázaros desta capital e da caixa pia da banda de música daquele Club.

O leilão efetuar-se-á no dia 17 do corrente. ${ }^{154}$

Outra forma de arrecadação era solicitar subvenção ao poder público, mesmo sendo instituição particular. Esse foi o caso, em 1890, quando o Club Literário da Villa de Santo

\footnotetext{
150 MELLONE, Dirceu Jair. Corpo musical: arte e profissão. Monografia apresentada ao Curso de Aperfeiçoamento de Oficiais-I/86, São Paulo: PMESP, 1986. p. 42.

${ }^{151}$ Banda de música italiana. A Província de São Paulo, 10 abr. 1889. Annuncios, p. 3.

${ }^{152}$ Notas e informações. O Estado de São Paulo, São Paulo, 8 jan. 1903, p. 2.

${ }^{153}$ Lei n. 851 de 28 out. 1902. Fixa a Força Policial para o anno de 1903. ALESP, São Paulo, 1902.

${ }^{154}$ Convite. Correio Paulistano, São Paulo, p. 2, 16 ago. 1890.
} 
Amaro, mediante um requerimento encaminhado à intendência municipal daquela localidade, pediu um auxílio para a manutenção da Banda de Música dos Menores e da escola noturna de instrução primária para os adultos naquele Club, conforme noticiado no Correio Paulistano de 30 de dezembro de $1890 .^{155}$

\subsection{Grupos de câmara}

Os cafés, confeitarias, restaurantes, bares e cafés-concerto que apareceram na cidade no final do século XIX, geraram um espaço aconchegante para o acolhimento de pequenos grupos musicais que se apresentavam a um público menor. Já no início do século XX, salões como a Confeitaria Fasoli, situada na Rua Direita $n^{\circ}$ 5, e a Rotisserie e Restaurante Sportsmann, situada na Rua São Bento no 91, tornaram-se dois dos exemplos claros de que, nesses ambientes, onde o menu vinha escrito em francês, os frequentadores eram os mesmos que também se faziam presentes nos teatros e outros espaços privados da cidade,

acostumados com repertórios eruditos e grupos "refinados" de músicos. O Correio Paulistano de 24 de novembro de 1903 traz a seguinte nota sobre um desses locais e seu “distinto público", a saber:

\section{O banquete de hontem.}

Realizou-se hontem às $71 / 2$ horas da noite, na Rotisserie Sportsman, o banquete offerecido pela maioria do Congresso Estadual aos srs. drs. Peixoto Gomide e Rubião Júnior, coronel Lacerda Franco e dr. Herculano de Freitas, presidentes e leaders do Senado e da Câmara dos Deputados. [...] No coreto, ladeado de vasos com flores e palmeiras, um sextetto, sob a regência do professor Spirandelli Dante, executou durante o banquete o seguinte programma: Nabuco - symphonia. Um ballo in maschera phantasia. Boheme - phantasia. Pizzicato - gavota. Si fetais roi symphonia. Manon Lescaut - phantasia. Cavalleria Rusticana - phantasia. Le Village - gavota. Girofle-Girofla - phantasia. Tannhauser - marcha. Uma secção da banda de música da Força Policial, tocou à porta da Rotisserie, várias peças, à entrada dos convidados que começaram a chegar pouco depois das 7 horas da noite. ${ }^{156}$

Pela suntuosidade do evento e a lista de autoridades que estiveram presentes nesse banquete, é possível identificar o prestígio que a Rotisserie possuía e reverberava. No final do século XIX, surgiu outro salão, o Paulicéia, que logo se transformou em um dos mais

\footnotetext{
${ }^{155}$ Requerimentos despachados. Correio Paulistano, São Paulo, p. 2, 30 dez. 1890.

${ }^{156}$ O Banquete de hontem. Correio Paulistano, São Paulo, p. 1, 24 nov. 1903.
} 
luxuosos da cidade, após ser renomeado Salão Progredior. O recinto foi inaugurado em 12 de dezembro de 1892 na Rua XV de novembro. Com o preço de \$500 (quinhentos réis) de consumação mínima às horas de concerto, o salão mantinha também concertos musicais gratuitos, conforme anúncio de $O$ Estado de São Paulo de 7 de junho de 1893. Em 8 de maio de 1903, o Correio Paulistano reportava um desses concertos de câmara, durante o qual o “excelente quarteto Albertini” faria a última de uma série de apresentações do grupo naquela casa. Naquela noite, abriu o evento um quarteto de Alexandre Levy em primeira audição, seguido por um Allegro moderato (quarteto) do prof. Paulo Florence, pianista (também em primeira audição). Uma peça de Ezequiel Ramos Júnior também foi executada e a apoteose se deu com o quarteto em dó maior (op. 74) de Haydn. ${ }^{157}$ Novamente, o repertório chama a atenção e se justifica pelo ambiente onde era executado, ambiente esse que selecionava explicitamente a plateia. Na época, surgiram outros salões tais como: o Café Java, no Largo do Rosário, o Café Brandão e Bar Majestic (situados na Rua de São Bento), além das Confeitarias Nagel, Stadt Coblenz e Imperial. ${ }^{158} \mathrm{O}$ surgimento de salões como os citados alavancou de certa forma a profissionalização do músico.

\subsection{Outros grupos musicais}

Como se sabe, grupos menores também eram empregados com frequência nessas atividades culturais e sociais. Mas, a partir da década de 1920, apareceu uma nova formação capaz de interpretar repertórios variados com um número reduzido de instrumentistas, redundando também em menores gastos para os contratantes e trazendo a praticidade de uma mobilidade mais eficaz, o que facilitava seus deslocamentos pela cidade quer em bondes ou automóveis: os jazz bands. A partir de 1925, a presença desses grupos passou a ser muito comum no Brasil, inclusive nos teatros. Sua instrumentação leve e extremamente versátil permitia uma combinação de timbres mais eficientes para os novos e diversos tipos de música e gêneros, permitindo implementar e sustentar as trilhas sonoras das peças encenadas, tocar em recepções, banquetes, jantares, bailes e todo tipo de evento. Até o final da década de 1930, conforme apresentado no capítulo 1, muitos grupos mantinham a instrumentação das cordas, como violinos ou violinos fone, banjos e um número pequeno de madeiras e metais. A seguir,

\footnotetext{
157 Salão Progredior. Correio Paulistano, São Paulo, 8 maio 1903. Platéas e Salões, p. 3.

${ }^{158}$ MORAES, José Geraldo Vinci de. Sonoridades paulistanas: final do século XIX ao início do século XX. Rio de Janeiro: Bienal, 1997. p. 164-173.
} 
a foto do Grupo Excêntrico do Teatro Polytheama do Braz (inaugurado em 1914) revela esse tipo de formação e instrumentação: bateria americana, piano, primeiro e segundo violinos, banjo, saxofone tenor e trompete. Vale lembrar que a fotografia, no entanto, registra um grupo da década de 1920, uma vez que, conforme aponta Alberto Ikeda ${ }^{159}$, a primeira bateria americana somente seria utilizada em conjuntos musicais como as Jazz Band, a partir da metade da terceira década do século XX. Mais tarde na década de 1940, as transcrições de peças escritas, originalmente, para grandes orquestras ou grupos de câmara para essas bandas substituiriam a instrumentação de cordas pelas madeiras (violinos por clarinetas, violas por saxofones contralto, violoncelos por saxofones tenor), congregando um "peso" considerável aos metais que passaram a variar entre três e quatro trompetes, mais três e quatro trombones.

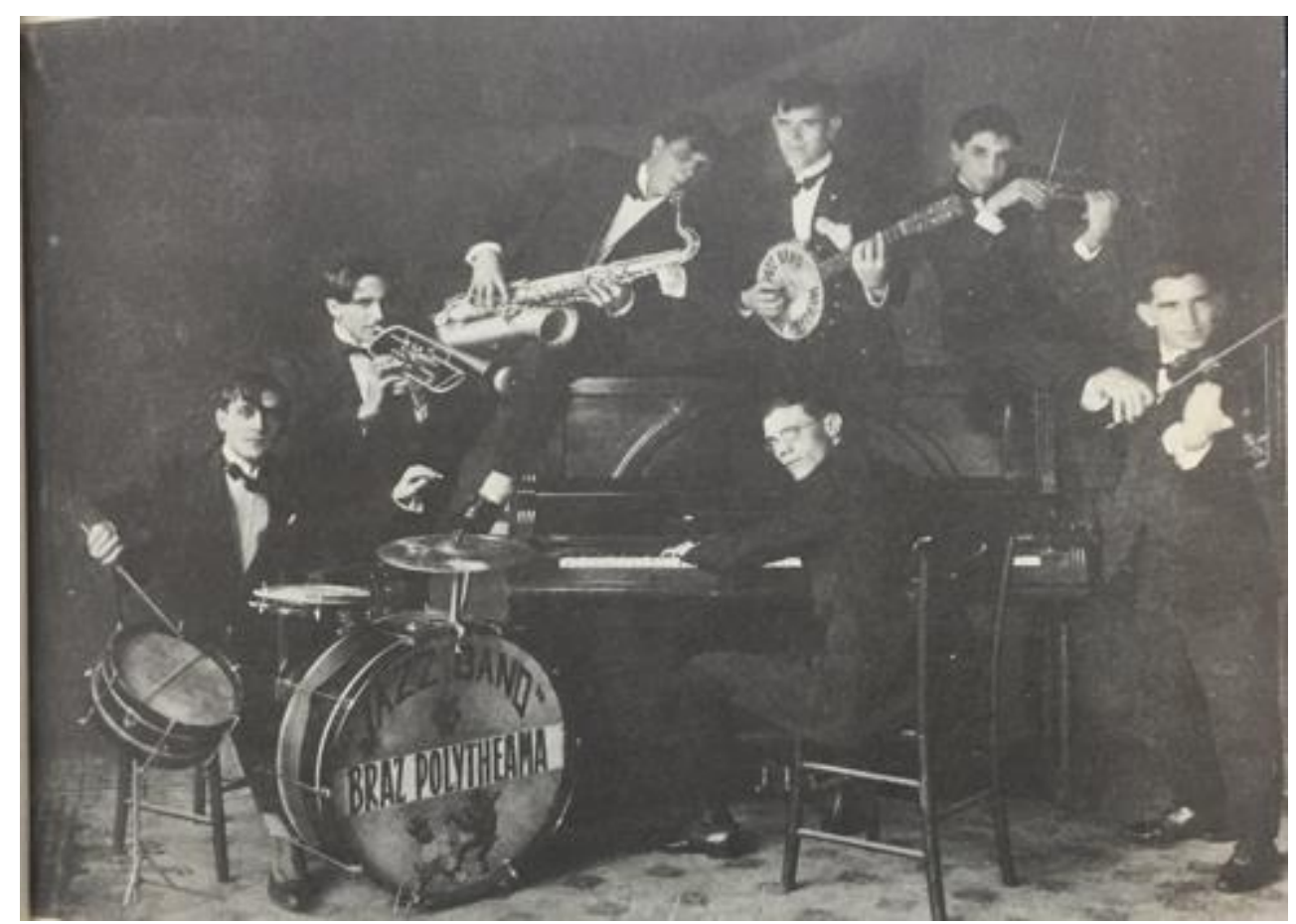

Figura 16.

Grupo Excêntricos - jazz band do Teatro Polytheama do Braz. Álbum de D. Theresa Bosi.

Extraído de: BOSI, Ecléa. Memória e sociedade: lembrança de velhos. São Paulo: Companhia das Letras, 2003. p. 147.

Estas bandas tornaram-se maiores e mais versáteis e, ao que tudo indica, o fenômeno das jazz bands multiplicou-se na vida musical da cidade, sobretudo atendendo às demandas de

159 IKEDA, Alberto T. Apontamentos históricos sobre o jazz no Brasil: primeiros momentos. Revista de Comunicação e Artes (ECA-USP), Ano 10, v.13, p.111-24, 1984. 
apresentações musicais em recintos fechados e, após a década de 30, as rádios. Não por acaso, a conhecida Casa Manon chegou a manter, em 1924, uma orquestra denominada Jazz Band Manon com a finalidade de atender a serviços em bailes, festas e clubes da cidade. ${ }^{160}$ Até as corporações militares trataram de organizar suas jazz bands, como foi o caso da Jazz Band Cruz Azul (contendo músicos da Força Pública do Estado de São Paulo), criada em 1927 com a finalidade inicial de arrecadar fundos para a construção do hospital da autarquia que ainda leva o mesmo nome; ela permaneceu viva oficialmente somente até o ano de $1932 .{ }^{161}$

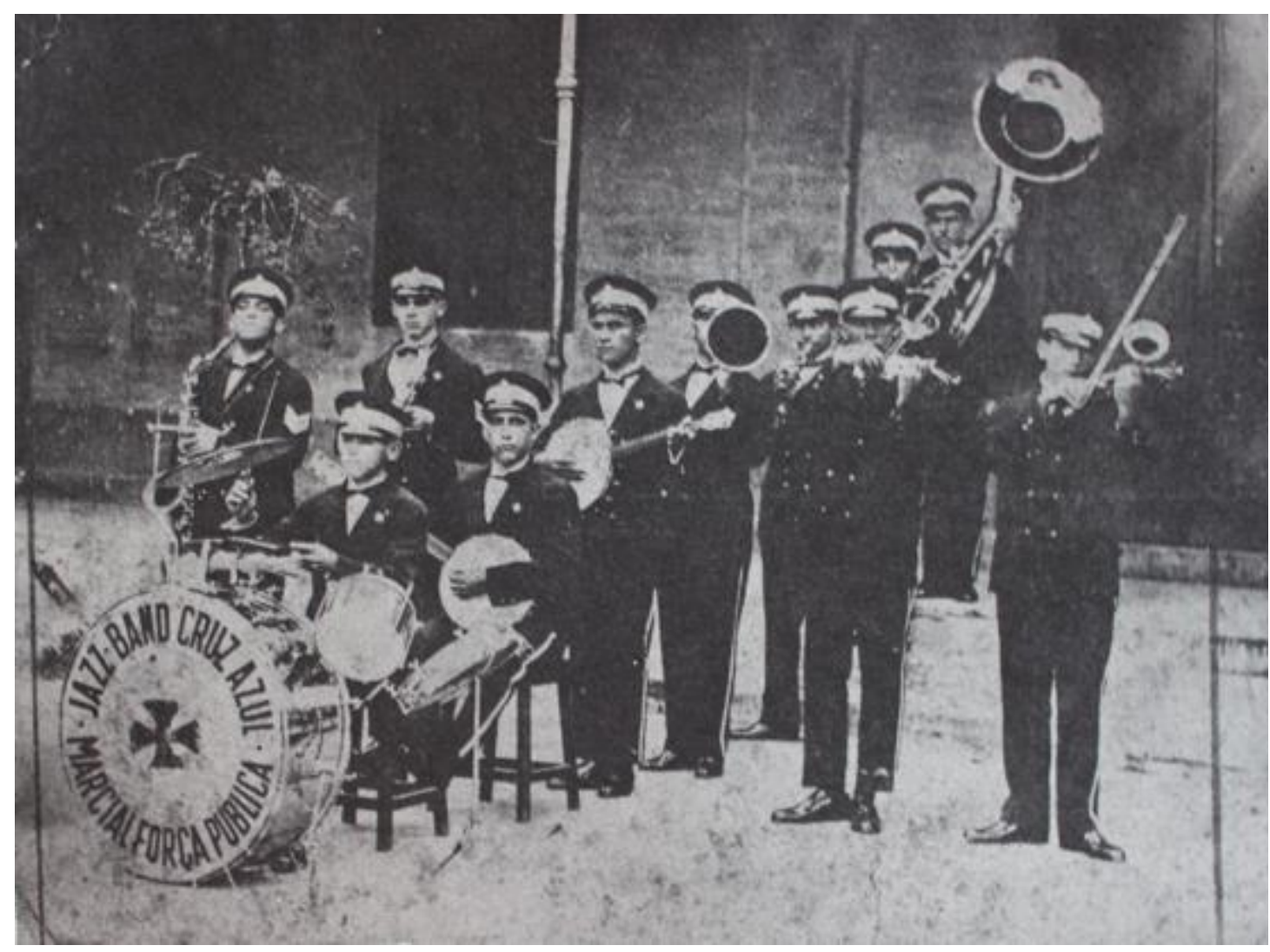

Figura 17.

Jazz Band Cruz Azul. Força Pública do Estado de São Paulo.

Fotografia de autor desconhecido. Data aproximada 1927.

Acervo fotográfico do Corpo Musical da Polícia Militar do Estado de São Paulo.

\footnotetext{
${ }^{160}$ Revista da música, São Paulo, n. 8, 1924 apud MORAES, José Geraldo Vinci de. Sonoridades paulistanas: final do século XIX ao início do século XX. Rio de Janeiro: Bienal, 1997. p. 164.

${ }^{161}$ Desativada em 1932, foi novamente chamada à ativa na década de 1990 pelo então major músico de Polícia Militar Rodolfo Antônio Cosignani, seu comandante à época. O autor exerceu as funções de saxofonista ( $2^{\circ}$ tenor e barítono) nessa nova formação da Jazz Band desde sua reativação em 1991 até 1997.
} 
Como se observa na fotografia acima, essa primeira composição das jazz bands ainda estava distante de uma formação maior e mais completa cuja formatação dos naipes de trombones, trompetes e saxofones passaria a predominar a partir da década de 1940. A formação da Figura 17 é de uma jazz band ainda desprovida de piano, ${ }^{162}$ que trazia dois banjos, um saxofone tenor, um saxofone contralto, dois trompetes, trombone, três violinos (sendo dois, na verdade, violinos-fone), um souzafone (não havia baixos elétricos ainda, portanto, o "calibre grosso" era todo dependente desse instrumento), e bateria americana como percussão. É importante ressaltar que o uniforme trajado por este grupo difere em muito do utilizado para desfiles. Nesse sentido, a intenção do fotógrafo pode ter sido a de produzir o efeito de galhardia, suntuosidade e classe, demonstrando que esse não era um grupo como os outros. ${ }^{163}$

Em suma, a São Paulo desta época apresentava grupos musicais para todos os tipos de gostos e ocasiões. No entanto, é necessário entendermos como os componentes desses conjuntos eram formados. Desvendar essa dinâmica é também um exercício simultâneo de compreensão sobre práticas sociais próprias das bandas de música da cidade, as quais acabavam por redundar na inserção profissional de parcela dos excluídos, como veremos a seguir.

\section{A formação dos músicos}

As bandas de música (militares ou civis) funcionaram como disseminadores culturais. Uma destas formas ocorreu por meio das relações de ensino-aprendizagem envolvendo, geralmente, a linguagem, a estruturação musical (ou teoria geral da música) e o instrumento. Ainda que de forma rústica, naquele momento da formação musical, a proposta geralmente constava de um aprendizado básico de rítmica, teoria elementar envolvendo figuras musicais, divisão de compassos simples, compostos, acidentes (bemóis, sustenidos e bequadros),

162 Boletim Geral, Força Pública do Estado de São Paulo. São Paulo, n.164, p.1.497, 16 jul. 1929. Este documento apresenta um pagamento de $30 \$ 000$ (trinta mil réis) para um pianista civil que, compondo a Jazz Band, apresentou-se no Teatro Santa Helena, evidenciando que é muito provável que a Banda da Força Pública àquele momento estivesse sem esse tipo de instrumentista e que, como forma de complementação da instrumentação de seu Jazz, lançasse mão dessa prática, contratando músicos civis para apresentações específicas.

${ }^{163}$ A fotografia foi realizada à frente da sala de ensaios no Quartel da Luz (hoje Quartel do Batalhão Tobias de Aguiar), situado na Avenida Tiradentes, local da sede do conjunto musical da Força Pública a partir de 1892 até o ano de 1954, quando se mudou para as instalações em que permanece até os dias de hoje, na Rua Jorge Miranda 367-A, no bairro da Luz em São Paulo. 
ligaduras e o domínio também básico do instrumento calcado em algum método prático, geralmente importado. ${ }^{164} \mathrm{O}$ resultado desse processo era que, após alguns meses, essa fórmula de aprendizado gerava a aptidão necessária para que o candidato pudesse compreender seu papel dentro do naipe no qual tomaria parte. Adquiridos os conhecimentos básicos para o aprendizado do instrumento musical (leitura, manuseio e técnica), o candidato estava apto a iniciar uma nova fase do aprendizado de forma prática, tocando, no respectivo naipe, as partes das quartas ou terceiras vozes.

À semelhança das antigas corporações de ofício, geralmente o pretendente ingressava ainda bem jovem, como aluno da "escola de música" 165 da corporação, exercendo as funções de bagageiro (carregador de estantes e instrumentos musicais, pastas de repertório) e prestando toda sorte de ajuda que fosse necessária para o bom funcionamento da corporação. À medida que os estudos progredissem (e isso dependia de vários fatores, como o interesse do aluno, a disponibilidade dos professores, as condições para prover as aulas e, é claro, a disponibilidade de algum instrumento para se emprestar ao aprendiz), ele passaria da percussão para outro naipe. A ideia, então, era a de manter uma certa educação continuada, com o objetivo de renovar os quadros à medida que os músicos mais antigos iam deixando a corporação e inativando-se pelos mais diversos motivos, como mortes, doenças incapacitantes, mudanças de cidade, incompatibilidade com outros trabalhos, etc. Vê-se, portanto, nessas corporações, um projeto institucional que, para além de executar música, acabou por ter o papel de formar músicos ao longo das décadas e, no caso de algumas delas, séculos, como ocorreu com a da Força Pública. Na São Paulo oitocentista ou do século XX, não foi diferente; além de colorirem a paisagem sonora da cidade, as bandas funcionaram também como formadoras de músicos para os demais conjuntos musicais, uma vez que a maioria dessas bandas (civis ou militares) possuíam "escolinhas de música".

Como algumas dessas bandas contavam com programas de aprendizado, o músico poderia até ser admitido nelas sem dominar a leitura, tocando de ouvido (especialmente os percussionistas, que em geral eram negros ou mulatos). Dessa forma, eram introduzidos nos

\footnotetext{
${ }^{164}$ Quanto aos métodos para instrumentos, somente a partir da década de 1950 é que autores brasileiros como Nabor Pires Camargo e Antônio Romeu (clarineta), e também Amadeu Russo (saxofones, trompete, trombone, tuba e bombardino) iniciaram suas publicações.

${ }^{165} \mathrm{O}$ termo escola de música aparece entre aspas porque a atividade-fim da banda não era propriamente formar músicos, mas, sim, executar música. A banda acabava por propiciar formação musical como forma de manter seus quadros.
} 
grupos, e iniciados a esse aprendizado ao longo dos anos até a completa compreensão da linguagem e estruturação musical. Como seu efetivo era em boa parte composto de mulatos, é possível que as bandas fossem um espaço que possibilitasse a tais músicos oportunidades que, em outras profissões, não conseguissem ter. Nesse sentido, para José Geraldo Vinci de Moraes, ${ }^{166}$ estava aberto, a partir dessa possibilidade, um dos caminhos da profissionalização do músico popular. A seguir, a fotografia (Figura 18) revela a presença de mulatos na composição da Banda da Força Pública de São Paulo em 1895. Dos 20 músicos que aparecem, alguns são negros e mais da metade apresenta traços de mestiçagem.

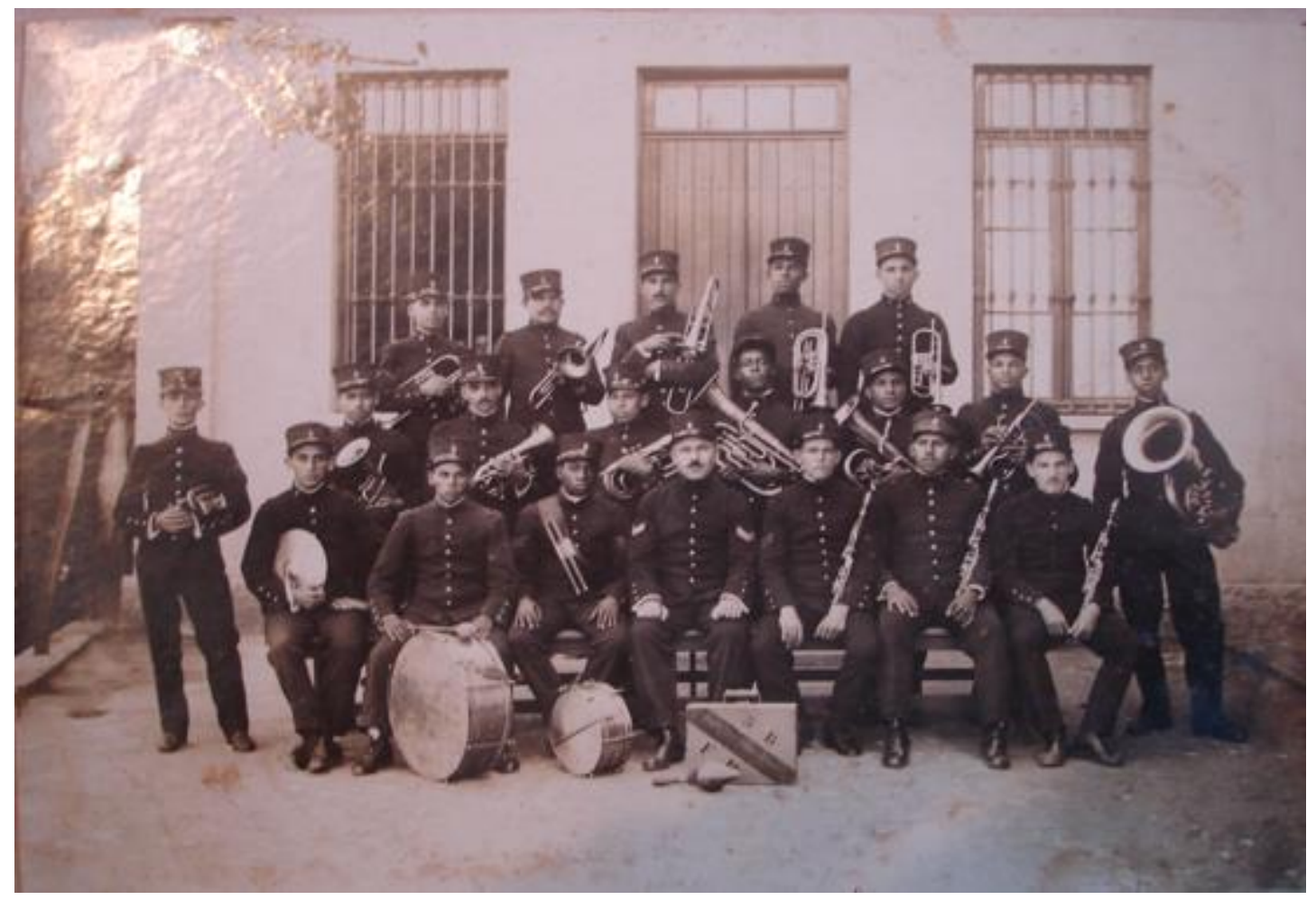

Figura 18.

Banda de Música do $5^{\circ}$ Batalhão de Infantaria da Força Pública do Estado de São Paulo. Fotografia de autor desconhecido. Data aproximada: 1895.

Acervo fotográfico do Corpo Musical da Polícia Militar do Estado de São Paulo.

Além das observações anteriores, a partir da Figura 18, é possível notar uma instrumentação básica na Banda. A organização está distribuída do seguinte modo: maestro (sentado ao centro em frente à caixa de repertório contendo as inscrições $5^{\circ}$ B. $\backslash$ F.P.), três

${ }^{166}$ MORAES, José Geraldo Vinci de. Sonoridades paulistanas: final do século XIX ao início do século XX. Rio de Janeiro: Editora Bienal, 1997. p. 151. 
clarinetas, três trompetes, dois flughelhorns, três trombones, uma trompa, um sax-horn (Chiquinha), dois bombardinos, um bombardão, bumbo, pratos e caixa clara. Há ainda uma maraca defronte à caixa, como acessório da percussão. Nota-se a ausência de saxofones, embora seu uso em larga escala tenha se iniciado nas corporações militares estadunidenses a partir da década de 1890. No Brasil, entretanto, só a partir da década de 1920 é que esses instrumentos foram implementados de forma sistemática, incrementando o naipe das madeiras, constituindo uma ponte entre as clarinetas (mi $b$ e si $b$ ) e os calibres tenores dos metais, o que possibilita um timbre mais suave nas transcrições das violas (saxofone contralto) e violoncelos (saxofone tenor) "amaciando", de certa forma, a aspereza que esses conjuntos militares possuíam, como podemos perceber nas gravações que acompanham este trabalho.

Escolas regulares diversas, orfanatos e instituições de ensino religiosas ou leigas também adotavam a fórmula de criar corporações musicais. Oferecendo atividade extracurricular aos alunos e possibilitando o aprendizado de um instrumento, as bases de um ensino de música profissionalizante de uma certa forma estavam lançadas. O Estado de São Paulo registrou, em 9 de setembro de 1902, a seguinte nota sobre uma dessas instituições que ofertavam o ensino da música:

O revmo. padre Marcos Simoni, diretor do corpo musical do Orphanato Christovam Colombo, communica-nos que a referida banda de música, composta de trinta e cinco figuras, pretende brevemente ir a Santos, afim de cumprimentar a imprensa local, as auctoridades e aos bemfeitores do Orphanato. ${ }^{167}$

Nesse caso, o que chama a atenção é a quantidade de músicos - 35 instrumentistas -, número bem acima da média de 20 músicos geralmente empregada em grupos desse tipo. Em outra nota, quase um ano mais tarde, o mesmo jornal trazia outra menção importante à Banda do Orphanato, elogiando-a e reportando que o conjunto havia sido muito apreciado em razão de sua instrumentação completa e sua execução aos olhos e ouvidos do redator, o qual a classificou como "muito regular". ${ }^{168}$ Dirigido pelo maestro Joaquim Capocchi, a Banda do Orphanato foi um dos exemplos de instituições que viam no ensino da música algo

\footnotetext{
${ }^{167}$ Notícias Diversas. O Estado de São Paulo, São Paulo, 9 set. 1902. p. 2.

${ }^{168}$ Notícias Diversas. O Estado de São Paulo, São Paulo, 14 jun. 1903. p. 3.
} 
mais do que o aprendizado da arte: uma oportunidade da aprendizagem de um ofício. Em nota de 16 de fevereiro de $1906,{ }^{169}$ o maestro pede que um jovem seja contratado pela Banda da Força Pública:

O sr. commandante da força publica vae informar o requerimento em que o padre Marcos Simoni, do Orphanato Christovam Colombo pede ao governo para ser admitido na banda musical da força um orpham asylado daquele estabelecimento. ${ }^{170}$

Menos de um mês depois do requerimento dar entrada no protocolo do comando geral da Força Pública, viria o despacho do coronel Argemiro Sampaio (então comandante daquela instituição), negando o atendimento ao pedido por não haver claros ${ }^{171}$ na Banda de Música para a admissão do interessado. ${ }^{172} \mathrm{O}$ fato do requerimento ter sido negado nesse momento não desmerece a tentativa. Pelo contrário, traz indícios de uma prática segundo a qual esses grupos cumpriam também um papel social de inclusão no mundo profissional de agentes que, oriundos de diversos lugares, entre eles, instituições de caridade, como é o caso do orfanato, poderiam ser inseridos de forma concreta no mercado de trabalho da música, graças aos conhecimentos básicos adquiridos dentro da instituição que o acolhera primariamente.

Tudo indica que as associações de imigrantes também tiveram importante papel na formação dos músicos, a começar pelo repertório, instrumentação, formação do gosto musical $^{173} \mathrm{e}$, finalmente, pelas relações ensino-aprendizagem da música. A programação musical de 1903 revela esse quadro: 26\% dos compositores eram de origem italiana, 8\% francesa, $6 \%$ alemã e $2 \%$ espanhola e austríaca, além de $1 \%$ estadunidense e croata, com os estrangeiros perfazendo $46 \%$ do total de obras executadas. Há também que se observar que $9 \%$ deles eram compositores brasileiros e $45 \%$ do total não puderam ser identificados, tornando-se impossível, portanto, atribuir nacionalidade a estes ${ }^{174}$. Avançando para 1915, os

\footnotetext{
${ }^{169} \mathrm{O}$ sentido de profissional neste caso é o de que, sendo admitido em uma banda militar, o músico perceberia um salário mensal capaz de prover seu sustento e eventualmente de sua família, tendo, portanto, a música como profissão. O termo assim é empregado no sentido de designar a estabilidade financeira gerada pelo ofício e não da capacidade musical que o candidato apresentava.

170 O Estado de São Paulo, São Paulo, 16 fev. 1906. p. 2.

${ }^{171}$ Claros, para a administração militar, é o resultado da subtração entre o efetivo fixado e o existente. Neste caso, o efetivo estava completo, sem vagas em claro para o ingresso do pretendente.

172 [sem título] $O$ Estado de São Paulo, São Paulo, 8 mar. 1906. p. 2.

${ }^{173}$ Como apresentado nas Figuras 6 a 15 do capítulo 1.

${ }^{174}$ Esses dados, no entanto, são passíveis de aperfeiçoamento em uma futura revisão, à medida que mais compositores listados poderão ser reconhecidos em suas nacionalidades; e, ainda que os indicadores
} 
números obtidos pelos 39 programas analisados revelam um total de $24 \%$ dos compositores de origem italiana, 14\% de alemães, $10 \%$ de austríacos e franceses, $4 \%$ de estadunidenses, $2 \%$ de tchecos, ingleses e poloneses, além da ascensão de compositores brasileiros (em relação a 1903) para a marca de 10\%. O número de compositores não identificados caiu também para $22 \%$, provavelmente, em razão das facilidades para identificação dos nomes divulgados pelas fontes e pela metodologia no tratamento dessas publicações à época. Do todo, observou-se um pequeno declínio de italianos, mas, ao mesmo tempo, uma elevação de outras nacionalidades. Para ratificar então a afirmação desta seção - a forte presença estrangeira e imigrante na formação musical de São Paulo -, 68\% eram compositores estrangeiros, $10 \%$ nacionais, além dos 22\% não identificados, 12 anos após a primeira sistematização. Para a concluir o resultado aferido dentro do recorte temporal pesquisado, tomou-se o ano de 1928, ${ }^{175}$ a respeito do qual foram encontrados e analisados 43 programas no total. Destes, os números resultantes demonstraram poucas mudanças no cenário apresentado em relação a 1915. Do total, 26\% de compositores eram italianos, $15 \%$ alemães, $11 \%$ austríacos, $8 \%$ franceses, $3 \%$ húngaros e argentinos, $1,5 \%$ poloneses, estadunidenses e tchecos, resultando num percentual aproximado de $69 \%$ de execuções de compositores estrangeiros contra $8 \%$ de brasileiros e $23 \%$ de nacionalidades não identificadas. Há, portanto, para os compositores estrangeiros, uma crescente ascensão de obras executadas: $46 \%$ em 1903, 68\% em 1915 e $69 \%$ em $1928 .{ }^{176}$

De certa forma, a crescente ascensão de obras executadas compostas por estrangeiros também foi apresentada no capítulo anterior, mas aqui o sentido é tentar compreendê-la no universo das relações ensino-aprendizagem das bandas de música. A existência e manutenção das associações de imigrantes que se interessavam pela música é um bom indício de que uma das formas de manutenção das tradições dessas associações se dava pelo viés da música. A maioria delas, na verdade, não tinham por prioridade a formação dos músicos. Tinham como objetivo a divulgação de um repertório de concertos e música de câmara, muito mais do que

demonstrem a produção musical de concertos de apenas uma corporação musical existente na São Paulo do início do século XX, é possível encontrar programas de concerto de outras corporações na grande imprensa, que possivelmente conduzirão aos mesmos números e resultados.

${ }^{175} \mathrm{O}$ ano de 1928 possui o maior número de programas que puderam ser resgatados e avaliados, entre todos os anos mensurados a partir de 1925. A coleta abarcou os anos de 1925 a 1930.

${ }^{176}$ É sempre preciso lembrar que muitos (se não a maioria) dos compositores não identificados devem ter origem estrangeira, o que, dessa forma, aumentaria esses números. 
o ensino musical. Esse foi o caso da Sociedade de Música Paulista, fundada em 1888, a qual, utilizando-se das dependências do Club Gymnástyco Portuguez, realizou, em 5 de outubro daquele ano, sua segunda reunião para a leitura e aprovação de seu estatuto por parte de seus associados. ${ }^{177}$ Ao que parece, as colônias empenharam-se em manter suas tradições, partindo de uma matriz cultural que se consolidou na nova terra pelos esforços da autopreservação; e isso incluiu claramente a música como um de seus principais elementos. Ao ofertar a possibilidade de formação de grupos e aprendizado dentro da própria sociedade e dos clubes, o objetivo estava assegurado e, praticamente, garantido, mantendo-se a cultura e as tradições mesmo em terras estrangeiras. Clubes de associações de imigrantes com nomes mais abrasileirados também se puseram a tocar e propagar a música de concerto na cidade, como foi o caso do Clube Musical Riachuelo e do Clube Literário da Vila de Santo Amaro, os quais, nos saraus, apresentavam concertos de música erudita, e do Grêmio Dramático João Caetano, além do Grupo Musical Carlos Gomes. Este último, conforme O Estado de São Paulo, fora reorganizado em 11 de março de 1906, sob a direção do maestro Synesio Melchiades, quando sua sede social passou a ser instalada na rua da Consolação $\mathrm{n}^{\mathrm{o}} 18 .{ }^{178}$

Conforme vimos até aqui, durante as três primeiras décadas do século XX, o cenário musical da cidade produziu instrumentistas de várias características, que geraram, por sua vez, inúmeros tipos de grupos musicais. Não adiantava apenas existirem celeiros musicais repletos de aspirantes e aprendizes nas bandas, orquestras e demais grupos e, muito menos, haver uma elite voltada ao consumo e apreciação de um repertório europeu já introjetado no gosto musical urbano. A existência de profissionais do ensino era necessária para consolidar políticas formais e informais de formação; neste caso, os professores.

\subsection{Professores e escolas de música}

Professores e escolas de música que formaram gerações de músicos dos diversos grupos que a cidade comportou foram responsáveis por um conjunto de profissionais e artistas habitantes e trabalhadores dessa cidade, desde o início da segunda metade do século XVIII. O árduo trabalho desses professores resultou, a despeito do cenário dificílimo em que atuavam, num boom da cultura musical a partir do início do século XX, como apresentado

\footnotetext{
177 Sociedade Musical Paulista. Correio Paulistano, São Paulo, p. 2, 5 out. 1888.

${ }^{178}$ Grupo Musical Carlos Gomes. O Estado de São Paulo, São Paulo, p. 3, 14 mar. 1906.
} 
neste capítulo. Entre 1850 e 1900, foram mapeados por Janice Gonçalves nada menos que 151 professores de música (teoria, instrumentos e canto), além de 39 escolas, colégios e liceus onde o ensino da música era apresentado sistematicamente. ${ }^{179}$ Dentro desse cenário, as bandas de música, oferecendo a oportunidade de uma profissão e condições mínimas de dignidade, inseriram parte daqueles que haviam sido excluídos de forma indireta pela Lei Imperial n 3.353 de 13 de maio de 1888.

A formação de músicos na São Paulo do período colonial veio da Igreja e em particular dos Jesuítas. Só no século XIX, a sistematização do ensino musical e, em especial, de instrumentos começou a ganhar corpo na cidade. Isso, em grande parte, foi em decorrência dos reflexos da vinda da Família Real em 1808, cujas novidades trazidas pelos Corpos Militares de música impactaram em princípio o Rio de Janeiro, chegando também a São Paulo anos depois. Longe de haver sido fácil, o ofício do ensino da música trouxe alguns problemas naquele início do século XIX, solucionados à medida do possível. Um dos principais problemas era o viver do ofício de ensinar. Aos poucos, os professores passaram a resolver esse tipo de problema, do mesmo modo que os músicos o faziam: trabalhavam dobrado ou possuíam duas profissões a fim de complementarem suas rendas. $\mathrm{O}$ trabalho de Janice Gonçalves traz um rol de professores atuantes na cidade de São Paulo, entre os anos de 1850 e 1900, em que são listadas profissões complementares desempenhadas por esses professores. Além de professores de música, a pesquisa da autora revelou que esses profissionais foram funcionários públicos, padres, engenheiros, diretores de escola, professores de geografia, matemática, línguas e ciências exatas. ${ }^{180}$

No aspecto econômico dessa dinâmica, a expansão que o estado de São Paulo sofreu na segunda metade daquele século gerou a possibilidade de aquisição de uma grande quantidade de instrumentos musicais (em especial, pianos) por parte das famílias e estabelecimentos de ensino, como escolas e lojas que também abrigavam aulas em suas dependências. ${ }^{181}$ Com o advento dos jornais a partir de $1854,{ }^{182}$ os profissionais da música

179 GONÇALVES, Janice. Música na cidade de São Paulo (1850-1900): o circuito da partitura. 1995. Dissertação (Mestrado) - Faculdade de Filosofia, Ciências Humanas e Letras, Universidade de São Paulo. Para os professores de música, p. 200-203; para as instituições de ensino regular de música, p. 207-209.

180 GONÇALVES, Janice. Música na cidade de São Paulo (1850-1900): o circuito da partitura. 1995. Dissertação (Mestrado) - Faculdade de Filosofia, Ciências Humanas e Letras, Universidade de São Paulo. p. 205-206.

${ }^{181} C f$. poderá ser verificado nas notas seguintes.

${ }^{182} \mathrm{O}$ primeiro jornal a circular periodicamente foi o Correio Paulistano a partir de 1854. 
passaram a ter um veículo de anúncio muito eficaz para divulgação de sua profissão e seus afazeres, como a composição, a regência, ou mesmo a interpretação por meio de algum instrumento, como o piano, por exemplo. Não há como se descontextualizar as importantes relações de ensino-aprendizagem da música pelo piano, lembrando que, conforme Mário de Andrade, a cidade teria a vocação para a "pianolatria". Desprezando os demais instrumentos, aquele seria o símbolo da elite paulistana durante quase todo século XIX.

No entanto, mais eficientes ainda seriam as ofertas para lecionar (quer fosse algum instrumento, canto, quer teoria musical ou outras disciplinas). Um dos nomes mais citados do século XIX, responsável pela formação de uma geração de professores paulistanos até o início do XX, foi o professor Gabriel Giraudon, que, embora fosse francês, radicou-se na cidade, sendo responsável pela educação musical de nomes como Henrique Oswald, os irmãos Levy e Magda Tagliaferro. Outro nome sempre recorrente no campo do ensino musical foi o do maestro italiano Luigi Chiaffarelli. ${ }^{183}$ Exemplos de publicações podem ser encontradas na seção de classificados da grande imprensa da época. Em O Estado de São Paulo de 2 de agosto de 1902, é possível encontrar esses tipos de anúncios, em que maestros se ofereciam para trabalhar tanto na capital quanto no interior do estado:

\section{Mestre de música italiano.}

Um mestre de música, italiano, procura um logar no interior, como director de qualquer banda: também lecciona qualquer instrumento de metal, corda e piano. Para informações, com o srs. D’Aló \& Irmãos Zacharias, rua Vinte e Quatro de Maio n. 40. S. Paulo. ${ }^{184}$

Na nota, é curioso que o endereço deixado para o contato era o da loja de instrumentos e acessórios musicais D’Aló \& Irmãos Zacharias, situada na Rua 24 de Maio nº 40, a qual, à semelhança da Casa Bevilacqua, transformava as dependências da loja em verdadeiros “escritórios de negócios" para esses músicos. Funcionando como arregimentadores de profissionais do ramo, locais como essa loja promoviam acertos de contratos de quase todos os tipos de prestação de serviços musicais, aulas de música, agenciadores de grupos musicais e músicos, e outras tantas atividades relativas ao universo musical, tornando-se referência para todo o meio profissional da música em São Paulo. Em 1915, ainda era possível encontrar

\footnotetext{
${ }^{183}$ MORAES, José Geraldo Vinci de. Arranjos e timbres da música em São Paulo. In: PORTA, Paula. (Org.). História da cidade de São Paulo. São Paulo: Paz e Terra. 2004. vol. 1. p. 596-597.

${ }^{184}$ Mestre de música italiano. O Estado de São Paulo, 2 ago. 1902. Annuncios, p. 4.
} 
notas nos anúncios dos jornais onde músicos e maestros dispunham-se para o trabalho. Em O Estado de São Paulo de 12 de março de 1915 (13 anos mais tarde), o jornal traz a oferta de outro maestro de banda de música ou orquestra que, além de ser compositor, desejava uma “colocação", aceitando proposta para o interior. O endereço para tratar do assunto, novamente, era uma loja comercial: os interessados deveriam se dirigir à Casa Scavone \& Com. Rua 24 de Maio no 36, São Paulo. ${ }^{185}$

Luigi Chiaffarelli (citado anteriormente), Giulio Bastiani, Guido Rocchi, Giácomo Foschini e Agostinho Cantu foram alguns desses professores de ensino privado, mas que também compuseram o corpo docente do Conservatório Dramático e Musical de São Paulo, que será abordado logo à frente. Outros, fizeram parte de corpos docentes de outras instituições sem terem seus nomes associados a escolas, como foi o caso de Torquato Amore, Ferrucio Arrivabene, Francisco Murino e Alfério Mignone (pai do compositor Francisco Mignone), Guido Santorsola, Francisco Casabona, Paulina D’Ambrósio, Zacarias Autuori, Félix Otero e João Sepe. ${ }^{186}$

Dos nomes acima, Felix Otero foi um dos instituiu uma das raras escolas de ensino sistematizado para o aprendizado da música. Em matéria publicada em O Estado de São Paulo, datada de 2 de maio de 1901, o professor esclarecia seu planejamento para a escola de música que pretendia abrir no dia $1^{\circ}$ de junho daquele ano, o que conseguiu. A escola possuía dois cursos distintos - o primeiro, de piano (elementar e superior), e o segundo, de música (teoria geral, desde as noções elementares até o estudo da harmonia) - que, seguindo os padrões modelados pelas instituições da Europa, dariam ao aluno uma visão mais abrangente da linguagem e estruturação musical, até a harmonização. Complementarmente eram previstos ensaios (práticas de orquestra e de conjunto) e, trimestralmente, apresentações musicais de alunos mais adiantados. Uma vez concluído o curso elementar de piano e após a devida aprovação no respectivo exame, os alunos eram promovidos ao curso superior com duração de 4 anos. Após a conclusão do curso superior, os alunos concorriam a prêmios ofertados por uma comissão de professores. A nota seguia parabenizando o professor e

\footnotetext{
185 Professores, aulas e cursos. O Estado de São Paulo, São Paulo, 12 mar. 1915. Annúncios, p.10.

${ }^{186}$ Uma das facetas mais conhecidas do maestro João Sepe foi o ensino da teoria musical e da harmonia, assim como sua escrita. Sua obra mais conhecida foi Tratado de Hamonia, editado pela Ricordi São Paulo no início da década de 1940, que norteou o ensino da referida disciplina dentro das escolas e grupos musicais da cidade (incluindo as bandas de música) tanto para maestros como para músicos.
} 
indicando que era a primeira vez na cidade de São Paulo que um curso desse gênero era posto em prática "onde se ensine methodica e progressivamente a música nas suas diversas modalidades". ${ }^{187}$ A escola funcionou no Palacete Lara na Rua Direita ${ }^{\circ} 17$, sobre a Casa Bevilacqua, o que, portanto, ratifica a ligação entre as lojas e o ensino de música na cidade.

Como destacado logo anteriormente, uma das mais marcantes instituições formadoras de músicos da cidade foi o Conservatório Dramático e Musical de São Paulo. Inspirado no Conservatório de Paris, foi o responsável pela construção da maior referência da Belle Époque na música de São Paulo. Tendo iniciado suas atividades em 1904 por iniciativa de Pedro Augusto Gomes Cardim (vereador à época) e João Gomes de Araújo, somente em 15 de fevereiro de 1906 foi oficialmente fundado, realizando sua cerimônia de inauguração um pouco mais tarde, em 12 de março daquele ano. Naquela data, no edifício da antiga Escola de Farmácia na rua Brigadeiro Tobias, realizou-se uma matinê literária musical que marcou o início do planejamento de suas atividades. ${ }^{188}$ As primeiras reuniões foram conduzidas no Clube Internacional e sua primeira diretoria eleita previa como presidente Antônio de Lacerda Franco, Carlos de Campos como tesoureiro e Pedro Augusto Gomes Cardim como diretor-secretário. ${ }^{189}$ Conforme consta em nota publicada em O Estado de São Paulo datada de 13 de março, o prédio que passara a abrigar o Conservatório encontrava-se todo ornamentado, ganhando o direito de receber uma Seção da Banda de Música da Força Policial para recepcionar os convidados, com a execução do Hino Nacional Brasileiro, regida pelo maestro Antão. Evento nada modesto, contou com as personalidades de Jorge Tibiriçá (então Presidente do Estado), Gustavo de Godoy (Secretário do Interior) Carlos Botelho (Secretário da Agricultura), Getúlio Monteiro (Presidente da Câmara Municipal), vereadores Ernesto Goulart, Corrêa Dias e Horta Júnior, e o tenente Pedro Dias de Campos, representando o comandante da Força Policial. Outras personalidades como Dr. Emílio Ribas, Mário Tavares, Azevedo Marques, Américo Brasiliense, Augusto Pereira de Queiroz, Numa de Oliveira, e os maestros Félix Ottero e Cardim também prestigiaram o salão. Houve ainda a presença de um grande número de senhoras e senhoritas “de nossa primeira sociedade”, deixando claro o

\footnotetext{
${ }^{187}$ Noticias Diversas. O Estado de São Paulo, São Paulo, 2 mai. 1901. p. 3.

$188 \mathrm{O}$ início de suas atividades de forma sistêmica (incluindo as aulas) é datada, no entanto, de 25 de abril de 1906.

189 AZEVEDO, Elizabeth Ribeiro. Conservatório Dramático e Musical de São Paulo: pioneiro e centenário. Revista Histórica, São Paulo, n. 16, p. 1-6, out. 2006.
} 
caráter elitista no qual a ideia do funcionamento dessa escola de música estava calcada. No programa, um Trio de Mendelssohn para piano, violoncelo e violino abriu o espetáculo, seguido de declamações e mais um Trio de Beethoven para piano, violoncelo e violino para deleite dos presentes (desta vez, tendo como pianista o maestro Chiaffarelli). ${ }^{190}$

O Conservatório não era apenas uma escola de música; muito além disso, exercia as funções de uma sociedade lítero-musical, oferecendo seu espaço para discussões de cunho artístico e político-cultural dentro de um ambiente favorecido pela música paulistana. ${ }^{191} \mathrm{Em}$ suas dependências quer na Rua Brigadeiro Tobias (seu primeiro endereço) quer na Avenida São João (sede própria após 1909), ocorreram muitos eventos além das aulas. Em O Estado de São Paulo de 29 de abril de 1915, um artigo narra um deles:

\section{CONCERTO EM BENEFICIO}

Conforme temos noticiado, realisar-se-á no próximo dia primeiro de Maio um grande concerto no Salão do Conservatório Dramático e Musical, em beneficio da Cruz Vermelha Franceza.

Nessa festa tomarão parte o barytono sr. Corbiniano Villaça e os maestros Z. Autuori, Belardi, A Oswald e Gonçalves. [...]

É muito variado o programa dessa festa, que com certeza attrairá grande concorrência. Além de vários números de musica e canto, haverá recitativos por algumas da senhoritas referidas acima.

Os bilhetes encontram-se à venda nas casas de música. ${ }^{192}$

Ainda em 1915, outro evento era noticiado nas dependências da escola, também de caráter beneficente. Uma matinê dançante, dessa vez em benefício das vítimas da seca no Norte, conforme anunciava $O$ Estado de São Paulo datado de 19 de setembro daquele ano. O evento foi promovido pelos sócios do "Rose-Club Paulista" e patrocinado por um grupo de gentis senhoritas. $\mathrm{O}$ baile começava às 13 horas em ponto, tendo como recepção os acordes de uma Seção da Banda de Música da Força Pública, gentilmente cedida por Eloy Chaves, (então, Secretário da Justiça). ${ }^{193}$ O Conservatório manteve estreitos laços entre os grupos musicais, formando profissionais e alimentando orquestras, bandas e grupos de câmara ao longo de todo o século XX.

\footnotetext{
${ }^{190}$ Conservatorio Dramatico. O Estado de São Paulo, São Paulo, 13 mar. 1906. Notícias diversas, p. 3.

${ }^{191}$ Para entender essa proposta, basta recorrer à formação da Sociedade de Cultura Artística, que utilizou o salão Steinway do Conservatório para seu primeiro salão musical e cujo escopo ultrapassou os limites da promoção e apreciação da "boa música".

${ }^{192}$ Concerto em Beneficio. O Estado de São Paulo, São Paulo, 29 abr. 1915. Artes e Artistas p. 4.

${ }^{193}$ Baile em beneficio. O Estado de São Paulo, São Paulo, 19 set. 1915. Notas e Informações, p. 4.
} 
O maestro da Força Pública, Joaquim Antão Fernandes, era um frequentador assíduo dos eventos do Dramático, criando um vínculo estreito com a instituição e seu corpo docente. Transitando entre a elite musical paulistana e fazendo-se notado com apresentações de sua banda, conforme foi visto desde o dia de sua inauguração. Não raro, convidava seus professores para tomar parte em bancas de concursos de Banda de Música organizados por ele e outros maestros da cidade. ${ }^{194}$ Vários eventos patrocinados pelo Dramático também contaram com a participação dos músicos da Força ao longo do século XX. Prova desse estreito relacionamento é que, no ano de 1928, um concurso para o cargo de $2^{\circ}$ tenente do Quadro de Oficiais Músicos da Força Pública seria organizado e realizado pelo Conservatório. ${ }^{195}$ Nas décadas de 1950 e 1960, o neto do maestro Joaquim, João Antão Fernandes, passou por suas salas de aula e graduou-se em instrumento (piano), composição e regência. Ingressando na Força Pública em 1964, 20 anos depois de seu ingresso, em 1984, assumiria o Corpo Musical da Polícia Militar do Estado de São Paulo tornando-se seu maestro titular e comandante até 1990.

Em síntese, a formação dos músicos em São Paulo ora se dava em escolas regulares, ora, quase de forma artesanal, em corporações musicais. Porém como vimos, a grande maioria dos músicos de banda não frequentou escolas regulares: obteve sua formação nas próprias corporações musicais. Com isso, ganha a música popular, que aproveita a autenticidade de tais músicos para imprimir ao tecido sonoro da cidade um estilo próprio de se fazer música: descompromissado da formação erudita, mas atrelado ao amálgama cultural da cidade de São Paulo. Nesse cenário, a indústria fonográfica não tardou a se aperceber

\footnotetext{
${ }^{194}$ A maioria dos músicos de banda na cidade de São Paulo não passou pelo Conservatório Dramático e Musical de São Paulo por um motivo muito simples: suas origens sociais os mantinham muito distantes das elites que fundaram e mantiveram a escola durante o longo período de sua existência. Como apontado neste capítulo, o aprendizado desses músicos acontecia dentro das próprias corporações e de forma rudimentar, sem objetivar a formação de compositores ou grandes maestros, ao contrário do que passou a ocorrer conforme as diretrizes formais do Dramático ao longo do século XX. Ainda assim, casos como o do maestro Antônio Romeu (1 ${ }^{\mathrm{a}}$ clarineta da Orquestra Sinfônica Municipal de São Paulo e major músico, maestro e comandante do Corpo Musical da Força Pública do Estado de São Paulo durante a década de 1940) e do maestro João Antão Fernandes (pianista, major músico e comandante do Corpo Musical da Polícia Militar do Estado de São Paulo), este aluno e aquele professor de clarineta, dão provas de que, mesmo que de forma não sistêmica, o Conservatório estendeu seus braços a quase todos os grupos da cena musical paulistana, incluindo essa e outras corporações musicais. ${ }^{195}$ No capítulo 3, esse assunto será retomado, quando será discutido o concurso que marcou o início de uma série, selecionando maestros para a composição do Quadro de Oficiais Músicos da Força Pública do Estado de São Paulo.
} 
desse fato como veremos. Antes, porém, é necessário entendermos os circuitos que o som percorreu pela cidade.

\section{Circuitos do som}

A ideia de descrevermos os circuitos do som nesta seção se encontra fundamentada na percepção de que o som dos diversos grupos musicais da cidade de São Paulo percorreu um determinado circuito, circuito esse dividido em três etapas ou fases distintas, a saber: a primeira, em que o som se divide entre os ambientes públicos fechado e aberto; a segunda, em que o som deixa o espaço público fechado ou aberto e vai para o privado; e a terceira, na qual o som sai do ambiente privado e volta ao público aberto ou fechado, através de mediadores como os grupos musicais, instrumentos solo, discos, aparelhos sonoros ou o rádio.

A primeira dessas fases estende-se do início da colonização até a década de 1920. No referido início da colonização, os cantores e instrumentistas encontravam-se, na maioria das vezes, em ambientes fechados ainda que públicos, como as igrejas e posteriormente os teatros. Decorrido algum tempo, por volta do final do século XVIII, esses grupos instrumentais migraram das igrejas e teatros para fora desses ambientes públicos fechados. Tocando mais em ambientes externos aos quais chamamos de espaços públicos abertos, esses grupos deram à cidade mais cor pelos seus timbres. A segunda fase se apresenta entre as décadas de 1920 e 1930, quando o disco alterou o caminho do som e o trouxe para o espaço privado das residências com o auxílio dos discos. A terceira fase se deu a partir da década de 1930, quando o som retornou finalmente, para os espaços públicos, mas, na maioria das vezes, mediado pelo disco e pelo rádio e não mais pelos grupos em apresentações ao vivo.

Para a análise do circuito do som, é preciso considerar de que forma ele foi parar nas ruas. Partindo do fato de que a Igreja e os regimentos militares, através de suas bandas de música, foram os principais responsáveis pelo encaminhamento do som do ambiente público fechado para o aberto, encontraremos a seguir exemplos desse ciclo sonoro.

As relações entre a Igreja, a formação musical e a construção da paisagem sonora de São Paulo dos setecentos e oitocentos são bem conhecidas. Detentora de espaços públicos internos e externos -, a Igreja teve também um papel de acolhimento e inclusão para a população negra por meio do universo musical, pela via das Irmandades, conforme apontam 
vários autores. ${ }^{196}$ É importante lembrar que a maioria das festas religiosas dependia de grupos musicais para sua animação e que, quando a paróquia não possuía sua própria orquestra ou banda, era necessário contratar uma que cumprisse esse papel. Muitas vezes, apelava-se para a boa vontade dos fiéis por meio de ofertas e recolhiam-se os valores necessários ao pagamento desses grupos. Algumas vezes, esses conjuntos também tocavam sem o devido retorno financeiro, apenas em troca de boa comida e bebida; outras vezes, recebendo parte das prendas que deveriam ser leiloadas nas quermesses.

Na primeira fase em que o som transita entre o ambiente público fechado e o ambiente público aberto, é possível afirmar que, até a década de 1920, a rua ${ }^{197}$ ainda era o grande palco para boa parte dos músicos da cidade e seus grupos, sobretudo as Liras e Filarmônicas. No início do século XX, havia um sem número de locais onde a música em ambiente aberto tomava contornos de lazer, como, por exemplo, era o caso dos Freges, espécie de bailes públicos em que se dançava ao som de música popular, especialmente o maxixe, frequentados por negros, brancos e mestiços. ${ }^{198}$

Em $1^{\circ}$ de agosto de 1891, o Estado de São Paulo noticiava que dia 16 daquele mês teria início, na Igreja da Consolação, o setenário - período de sete dias que antecedia as comemorações da grande festa - do Divino Espírito Santo, sendo os festejos realizados com acompanhamento de música e grande orquestra. No dia 22 de agosto, véspera da festa e término do setenário, haveria iluminação veneziana, leilão de prendas e apresentações musicais de uma excelente banda de música, em um coreto especialmente preparado para a festa. Seriam também queimados fogos de artifício em um show pirotécnico, terminando os festejos no dia 23 quando, às 11 horas da manhã, haveria uma missa cantada com grande orquestra, estando a pregação do evangelho a cargo do reverendo padre mestre João Ferrão. Tudo seria encerrado com a procissão do Divino às 5 horas da tarde, e o andor seria carregado pelas senhoras. ${ }^{199}$

Na maioria das vezes, as rotinas das festas religiosas seguiram da mesma forma, fossem as comemorações do Divino Espírito Santo como neste relato, as festas da Santa Cruz

\footnotetext{
${ }^{196}$ Dentre eles podemos citar: José Geraldo Vinci de Moraes, Laura Della Mônica e Miguel Milano.

${ }^{197} \mathrm{O}$ termo rua, nesse momento, é utilizado no sentido lato, incluindo os largos, praças, parques, jardins e locais abertos da cidade onde fossem possíveis e viáveis apresentações de grupos musicais, quer fossem grandes ou pequenos, como duos e trios seresteiros.

${ }^{198}$ PINTO, Maria Inêz Machado Borges. Cotidiano e sobrevivência. São Paulo: EdUSP, 1994. p. $252-253$.

${ }^{199}$ Noticias Diversas. O Estado de São Paulo, São Paulo, p. 2, 1 ago. 1891.
} 
dos Enforcados, Santa Cruz do Pocinho ou das outras inúmeras existentes na cidade, razão para encontros, devoção e práticas sociais. A Igreja deixou um rol de grupos e músicos que ajudaram a construir a paisagem sonora paulistana, dentre eles, os alunos e componentes de corporações a ela ligadas de forma direta ou a instituições sociais por ela mantidas, como foi o caso das bandas do Seminário Episcopal de São Paulo, do Lyceu do Coração de Jesus dos Salesianos e a do Orfanato Cristóvão Colombo, instituição dedicada a receber órfãos da imigração. Assim como no teatro, o som aos poucos saiu da igreja para ganhar também as ruas e suas festas.

Igrejas e seus pátios, teatros, praças, cinemas, restaurantes e circos foram pontos de origem e produção do som, que se tornou, portanto, público. No entanto, essa forma de musicar a cidade sofreria sua maior alteração quando da chegada da manivela - representante da modernidade - e do gramofone, traçando uma mudança de caminhos nessa dinâmica.

Antes do disco, é preciso lembrar que foi o crescimento da urbanização nas grandes cidades do mundo que produziu uma demanda e consequente oferta por diversões, conforme afirma Eric Hobsbawm. ${ }^{200}$ Era preciso entretenimento para a classe pobre operária que nascia nesses centros urbanos. Nesse contexto, não é possível dissociar a música de tais práticas culturais. No Correio Paulistano de 15 de fevereiro de 1903, tem-se uma ideia sobre esses mecanismos de lazer criados na cidade de São Paulo. Enfaticamente reforçados pela administração pública a partir do último quartel do século XIX, envolviam as bandas de música nesses ambientes públicos (abertos e fechados):

\section{OS DOMINGOS PAULISTAS.}

Temos para hoje as seguintes diversões:

Espetáculos no Sant'Anna de dia e de noite, como Martyr do Calvário; dois espetáculos variados no Polytheama; corridas de cavalo no hippodromo; visita ao Ypiranga, das 10 horas às 4; excursões à Cantareira, trens de hora em hora; à Avenida, bondes de 15 em 15 minutos; à Penha, de 40 em 40 minutos; à Santo Amaro, de meia em meia hora; música no parque Antarctica e inauguração de um hippodromo mechanico, sendo o serviço de bondes muito melhorado; música no Jardim da Luz à tarde e das 8 às 10 da noite; música no Jardim do Palácio à noite; concerto no Progredior, no Fasoli e na Rotisserie. ${ }^{201}$

\footnotetext{
${ }^{200}$ HOBSBAWM, Eric. A história social do jazz. Rio de Janeiro: Paz e Terra, 1990, p. 59 e 60, apud MORAES, José Geraldo Vinci de. Metrópole em sinfonia: história, cultura e música popular na São Paulo dos anos 30. São Paulo: Estação Liberdade, 2000. p. 19.

${ }^{201}$ Os domingos paulistas. Correio Paulistano, São Paulo, 15 fev. 1903. Echos, p. 2.
} 
Conforme se pode constatar pela nota anterior, havia diversões para todos os gostos e bolsos, lembrando que quase sempre os recintos fechados selecionavam seu público por critérios distintos. Se não fosse pelo valor do ingresso, como no caso das casas de espetáculo e teatros (e aqui cabe a lembrança de que este se constituiu e ainda continua a ser um dos principais meios de exclusão do acesso à cultura), o próprio lugar, quando aberto, impunha condições veladas de frequência. Tal seleção podia se dar por meio de símbolos sociais que se traduziam, por exemplo, no trajar ou na capacidade financeira de pagar os gastos de um café ou jantar em ambientes como a Rotisserie (Sportsman) ou o Salão Progredior. Mas, como havia festa nas ruas e em locais públicos abertos, foi lá que o circuito do som ecoou, ganhando e formando o gosto musical dessa classe operária que crescia.

É importante frisar que esse gosto musical foi criado por um repertório que passou a ser executado a partir da última década do século XIX, transposto das orquestras de dentro das salas de concerto para as ruas, pelas mãos de copistas e arranjadores. Conforme se pode constatar em uma nota de classificados em O Estado de São Paulo datada de 12 de janeiro de 1902, um desses copistas (anônimo), domiciliado na rua dos Guayanazes no 61 em frente ao Largo, oferecia-se para, a preço razoável, copiar quaisquer músicas. ${ }^{202}$

Por meio dos dados das Tabelas 8 a 15 (Anexo I), é possível ter a dimensão do quanto esse tipo de música caminhou de dentro das salas de concerto ou dos salões de dança para as ruas. ${ }^{203}$ Nesse primeiro momento, o sentido sonoro ocorreu do interno (público ou privado) para o externo (essencialmente, público). Refazendo esse circuito, é possível entender de onde o som partiu antes de ganhar as ruas para poder se compreender a formação do músico popular nas primeiras décadas do século XX.

Também dentro desse ambiente, os teatros, assim como as igrejas, eram recintos públicos (porém, fechados e com ampla possibilidade de seleção de seus frequentadores), que representaram a primeira parte do circuito do som, pois, em um momento anterior, o que era produzido nesses recintos não chegava às ruas, ou seja, embora o recinto fosse público, o som era privado e apreciado por uma parcela seleta da população. Corroborando a lógica

\footnotetext{
${ }^{202}$ Copista de música. O Estado de São Paulo, São Paulo, 19 fev. 1902. Annuncios, p. 4.

203 Apresentam os programas de concerto executados pela Banda de Música da Força Pública do Estado de São Paulo nos anos de 1903, 1915, 1925, 1926, 1927, 1928, 1929 e 1930 respectivamente.
} 
de Eric Hobsbawm, ${ }^{204}$ conforme estudos realizados por Elizabeth R. Azevedo, ${ }^{205}$ São Paulo sofreu uma verdadeira explosão de teatros a partir do período republicano, o que gerou espaço e oportunidade para uma série de trabalhadores da indústria de diversões, incluindo os músicos.

É importante lembrar que os conjuntos formados por esses teatros serviam para atender exclusivamente às suas demandas de serviço e não constituíram orquestras profissionais, pelo menos não até a década de 1930, como vimos. Isso gerava espaço e mercado para o exercício do ofício de músico nesse ambiente (ainda que sem exclusividade), permitindo a esses músicos o livre trânsito entre os diversos teatros. Foi justamente por meio dos teatros e do gênero musical que neles se apresentava, que as bandas começam a intermediar também o repertório que passou a ser executado, a partir da metade da última década do século XIX. Aquilo que era tocado no palco, interpretado pela voz de um barítono, passou a ser apresentado no Jardim da Luz ou no Largo do Palácio na voz de um solo do bombardino. Como o lugar dessas bandas nos teatros era o saguão, o restaurante ou as escadarias em frente à casa de espetáculos, o som deixou, a partir de então, o ambiente fechado - o palco desses teatros - para ganhar as ruas através das bandas de música.

Em 14 de dezembro de 1890, Ernani, ópera de Giuseppe Verdi com 46 anos de existência àquele momento, estava em cartaz no Teatro São José. Saindo daquele espaço público interno, Ernani desceu dos palcos e aportou seu terceiro ato no Jardim do Palácio, mediada pela Banda da Força Policial. ${ }^{206}$ Guardadas as devidas proporções, mesmo havendo privilégios para as elites na assistência dos concertos nesses locais públicos de recinto fechado (teatros), o que é reportado pelo cronista Jorge Americano ${ }^{207}$ e D. Jovina na obra de Ecléa Bosi, ${ }^{208}$ abriu-se, a partir daquela última década de século, a possibilidade de que o som fosse percebido como paisagem e começasse de forma simbiótica a integrar a cidade, fazendo-se sentir e soar pelo lado externo destes recintos chamados aqui de espaços públicos

\footnotetext{
${ }^{204}$ HOBSBAWM, Eric. A história social do jazz. Rio de Janeiro: Paz e Terra, 1990. p. 59-60 apud MORAES, José Geraldo Vinci de. Metrópole em sinfonia: história, cultura e música popular na São Paulo dos anos 30. São Paulo: Estação Liberdade, 2000. p. 19.

205 AZEVEDO, Elizabeth R. O teatro em São Paulo 1554-1954. In: PORTA, Paula (Org.). História da cidade de São Paulo. São Paulo: Paz e Terra. 2004. vol. 1. p. 575-583.

${ }^{206}$ Corpo policial. Correio Paulistano, São Paulo, p. 1, 14 dez. 1890.

207 AMERICANO, Jorge. São Paulo naquele tempo - 1895-1915. 2. ed. São Paulo: Carrenho Editorial/ Narrativa Um/ Carbono 14, 2004. p.191.

${ }^{208}$ BOSI, Ecléa. Lembrança de D. Brites. In: BOSI, Ecléa. Memória e sociedade: lembrança de velhos. São Paulo: Companhia das Letras, 2003. p. 285-286.
} 
fechados. Socializar a música de concerto, formando gosto e público, passou a ganhar uma importância quase de missão (nem sempre evidente) para essas bandas. Nessa dinâmica, espaços abertos como o velódromo paulista e os campos para jogos de futebol passaram a receber sua presença, e constituíram-se em partes integrantes da difusão musical, consolidando o sentido de divertimento público.

A partir da segunda metade da década de 1910, os concertos musicais da Banda da Força Pública aos poucos começaram a migrar do Jardim da Luz e do Jardim do Palácio para a esplanada do Teatro Municipal de São Paulo, onde, no lado de fora, passou-se a ouvir, se não o mesmo, um repertório muito parecido com o que era executado no palco do teatro. Em 12 de janeiro de 1915, o programa escolhido pela Banda na esplanada do Municipal incluiu Rienzi, sinfonia de Wagner, Violeta, valsa de Waldteufel, La Boheme, fantasia de Puccini, Ronde des archers, de Burgmein, Aida $-2^{\circ}$ ato, de Giuseppe Verdi, Amor cigano, valsa de Franz Lehar e Marcha Turca, de Mozart. ${ }^{209}$

Pelo programa apresentado, percebe-se que, para o músico, pouca diferença fazia o lado em que ele estava tocando no teatro, se dentro ou fora, uma vez que as obras eram em síntese as mesmas. Para a elite, melhor seriam as acomodações confortáveis do lado interno; mas, para o transeunte, os operários e os menos favorecidos, a possibilidade de ouvir "o som do teatro" pelo lado externo do mesmo prédio poderia representar a ilusão de uma igualdade mediada por corporações compostas de músicos que muito tinham em comum com operários, o que igualava ou encurtava de forma ilusória a distância causada pela acomodação social dos ouvintes. Tal prática rompia, portanto, a consciência de classe imposta pela dura vida das primeiras décadas do século XX. O problema é que esse sentimento ilusório durava quase apenas poucas duas horas, tal qual um filme exibido pelo cinematógrafo.

A rua, portanto, o maior e mais democrático palco musical da cidade, comportava uma quantidade ilimitada de músicos e, desde que quisessem, podiam se apresentar. Nesse contexto, não havia limites nem à criatividade nem ao talento. Jorge Americano narra o homem dos sete instrumentos como exemplo dessa versatilidade na ocupação das ruas da cidade por meio de seus sons:

Trazia uma série de coisas penduradas ao corpo com barbantes e couro. O bumbo vinha às costas, preso à tiracolo por um couro. Amarrada ao braço,

\footnotetext{
${ }^{209}$ Concerto publico. O Estado de São Paulo, São Paulo, 12 jan. 1915, Notícias diversas, p. 5.
} 
voltada para trás, estava a raqueta, "bumbada" com o movimento do cotovelo. Os "pratos" por cima do bumbo eram acionados pelo mesmo movimento do braço, do qual saía o barbante, que passava por uma haste de madeira no topo do bumbo. Movido o braço, o barbante levantava o "prato"; afrouxando o barbante, o "prato" caía e ressoava. O saxofone e a flauta, amarrados juntos, eram soprados alternadamente. A gaita de foles era "bombada" com o pé. O triângulo ressoava ao toque da haste metálica, com a mão que no momento estivesse disponível. Trazia uma espécie de coroa ou capacete de guizos, de sons vários. Sacudida a cabeça, os guizos ressoavam. Depois corria o pires. ${ }^{210}$

Como pode ser percebido pela narrativa desse autor e de outros, como Maria Inêz Machado Pinto em Cotidiano e sobrevivência, ${ }^{211}$ a rua foi o palco magistral para os profissionais que nela ganharam seu sustento diante das dificuldades que se desenrolaram durante o primeiro período republicano. Músicos de todos os tipos, de todos os cantos, bem formados, mal educados, sacros, profanos, populares, "de ouvido", seresteiros, de orquestras, "fazendo bico" em conjuntos menores, ou de bandas, foram artistas e profissionais que transitaram nessas ruas da cidade, construindo e, aos poucos, sedimentando a paisagem sonora desta. Todos colaboraram para aliviar as tensões desse difícil período, na mesma medida em que, das mais diversas formas, foram igualmente auxiliados na árdua tarefa da sobrevivência pela arte da música, reforçando a pavimentação do caminho sonoro nos sentidos externo e público. Não que o som público interno deixasse de existir! Teatros e uma série de salões de associações também ganharam força nas três primeiras décadas do século $\mathrm{XX}$, em razão do movimento imigrante e do operariado, mas, de todos esses cenários, a rua foi o principal palco. Dentro desta análise, impossível seria deixar de mencionar as praças, para fechar a ideia do circuito sonoro no sentido público para o privado.

Entre as duas últimas décadas do século XIX e as primeiras do XX, havia vários espaços públicos onde esses grupos se apresentavam; o Jardim da Luz e o Jardim do Palácio eram apenas dois deles e talvez os mais cobiçados. Remodelados no início do XX e aptos a receber tanto as bandas quanto o público expectador, os jardins ou praças sempre representaram um local de excelência para integrações sociais e familiares, representando diversão. Nesse espaço, a preocupação com o lazer aparece desde administrações do segundo reinado. Estas duas praças da cidade de São Paulo disputaram, durante o primeiro período

\footnotetext{
${ }^{210}$ AMERICANO, Jorge. São Paulo naquele tempo (1895-1915). 2. ed. São Paulo: Carrenho Editorial/ Narrativa Um/ Carbono 14, 2004. p. 154

${ }^{211}$ PINTO, Maria Inêz Machado Borges. Cotidiano e sobrevivência. São Paulo: EdUSP, 1994. p. 167.
} 
republicano, a presença das melhores bandas de música daqueles anos. Havia uma severa preocupação do poder público com a oferta das apresentações dessas corporações, a fim de atraírem ouvintes e usuários a esses espaços. Isso se devia, em parte talvez, à necessidade de justificar os investimentos feitos de forma sistemática, na construção e reformas das praças e jardins visando a cobrir uma demanda pelo consumo de cultura dentro da região do triângulo.

Em O Correio Paulistano de 8 de fevereiro de 1903, encontramos a edição da Lei n. 628, trazendo o seguinte texto:

Lei n. 628, de 7 de fevereiro de 1903. Autoriza o augmento de 3:000\$000 na verba <Jardins etc > da lei n. 552 de 28 de outubro de 1901.

O doutor Antonio da Silva Prado, Prefeito do Municipio de S. Paulo, faz saber $[\ldots]$

Art. $1^{\circ}$ Fica o Prefeito autorizado a augmentar averba <Jardins etc> [...] na importância de três contos de réis $(3: 000 \$ 000)$ a fim de occorrer ao pagamento da banda de música e outras despesas imprevistas. ${ }^{212}$

A Lei supracitada apresentava, na verdade, a alteração de outra anterior: a n. 552 de 28 de outubro de $1901 .{ }^{213}$ Pela n. 552, a verba destinada à conservação dos parques e jardins estava implícita nas despesas do município, não havendo dotação própria para o pagamento de bandas de música, situação que foi corrigida pela Lei n. 628, o que ressalta, ainda que de forma velada, a importância que esses instrumentos de lazer tomaram nas diversões da cidade. Vale lembrar que, em 1903, as bandas que tocavam no Jardim da Luz e no Jardim do Palácio eram, geralmente, da Força Pública, do $10^{\circ}$ Regimento de Cavalaria do Exército brasileiro e a Ettore Fieramosca. Portanto, essa verba se prestava não a uma única corporação, mas sim àquelas que efetivamente tocassem nesses espaços.

Palcos triunfantes da fase áurea da sonoridade das ruas, os jardins marcaram gerações pelas programações culturais que recebiam e pelas facilidades de locomoção que a mobilidade urbana apresentou a partir do início do século XX, sobretudo com a expansão do serviço de bondes elétricos promovido pela Light. $\mathrm{O}$ espaço para as apresentações no caso do Jardim da Luz era tão bom e amplo que, às vezes, eram acomodados dois grupos tocando

\footnotetext{
${ }^{212}$ Lei n. 628 de 7 fev. 1903. Autoriza o augmento de 3:000\$000 na verba <Jardins etc> da Lei n. 552 de 28 de outubro de 1901. ALESP, São Paulo, 1903.

${ }^{213}$ Lei n. 552 de 28 out. 1901. Orça a receita e fixa a despesa do município de São Paulo para o ano de 1902. PMSP. São Paulo, 1902.
} 
simultaneamente e, ambos os coretos, ficaram registrados por memorialistas e cronistas da época, como locais de alegria e diversão, onde as famílias moradoras do Centro podiam se encontrar para apreciar a música das bandas e passar bons momentos desfrutando de uma coletividade que via nestas um elemento socializante e agregador. Dentro do triângulo, ainda se pode citar, como espaço para as apresentações musicais, a Praça da República, reformada também no início do século XX e o Largo do Teatro, que desapareceu, posteriormente, para a construção da atual Praça João Mendes. Nesse espaço, havia um coreto onde a Banda do Corpo de Bombeiros dava concertos às quintas feiras e domingos ${ }^{214}$ até sua extinção por volta de 1897.

Mais tarde, outros espaços públicos e abertos começaram a se somar a estes, como foi o caso da esplanada do Teatro Municipal que, recebendo conjuntos musicais de médio e grande porte, como o da Força Pública, por exemplo, passou a ampliar seu símbolo de sonoridade erudita, ainda que em seu espaço externo, conforme já apontado.

Nem no centro, nem tão longe dele, mas já fora do triângulo, o Largo da Concórdia (início do Brás) concorria esplendorosamente para as diversões da classe operária que para lá se mudou com as novas remodelações ocorridas dentro da zona do triângulo no início do século XX, elevando sobremaneira os valores dos aluguéis. Sobretudo, aos finais de semana, o afluxo de pessoas para as audições dava-se em uma tonalidade regionalista. Os moradores do bairro ou de lugares próximos, vizinhos no sentido da Zona Leste da cidade, apreciavam as práticas de reuniões e encontros ao som da música executada pelas corporações sediadas também nas localidades ou em bairros vizinhos, como a União Republicana do Brás e da Guarda Nacional (também do Brás) ou mesmo a Bersaglieri do Bom Retiro. A preocupação do poder público com esses espaços de lazer ficava clara pelas melhorias que se promoveram ao longo do tempo em que o centro também era reformado. No entanto, é possível que o objetivo de proporcionar atrativos culturais a essa população operária em seus bairros, tivesse a real e camuflada intenção de mantê-la excluída e longe dos espaços e dos atrativos apresentados no triângulo. Em 15 de novembro de 1902, data escolhida não por acaso, a Prefeitura inaugurava o novo coreto na Concórdia:

Amanhan, às 5 horas da tarde, será inaugurado o coreto ultimamente construído por conta da prefeitura no largo da Concórdia.

${ }^{214}$ MILANO, Miguel. Os fantasmas da São Paulo antiga. São Paulo: Ed. UNESP, 2012. p.111. 
Por ocasião da festa inaugural, a banda de musica da União Republicana do Braz, tocará, sob a direção do professor Libório Passaro.

Aos domingos, à tarde, haverá sempre um concerto musical naquele local. $^{215}$

Espaço concebido às práticas musicais, o coreto fora reformado e reinaugurado, acomodando culturalmente, de certa forma, a população que fora excluída e forçada a deixar o centro da cidade. Com o tempo, os espaços de diversão foram se alargando à medida que os tentáculos do "Polvo Canadense" 216 se abriam pela cidade. Exemplos de locais distantes do triângulo central conforme comentado no capítulo 1, foram o Parque Antarctica na Zona Oeste e o Parque da Cantareira na Zona Norte, que, à semelhança dos Jardins do centro, passaram a contar com apresentações musicais dos mais diversos grupos, incluindo até sessões de "cinematógrafos", como foi o caso de um evento realizado no mesmo Antárctica em 8 de novembro de 1903. Lá, além das atrações do dia que contaram com a presença da banda Giuseppe Verdi, na noite daquele domingo, ainda houve a exibição gratuita de um cinematógrafo. $^{217}$

Na modernidade, ${ }^{218}$ pode-se entender que as necessidades que emergiram trouxeram consigo a estruturação de uma língua nacional, uma literatura nacional, uma História Nacional, o Hino Nacional e uma música Nacional. Tais mudanças proporcionaram a necessidade do indivíduo se imaginar membro de uma comunidade defendida como nação. Fizeram surgir o mundo urbano-industrial, que foi o mundo da ruptura, que deixou de ser comunidade para se tornar o mundo das instituições burguesas. Em especial, a República passou a representar esse mundo moderno tendendo a transformar as sociedades mais fechadas em sociedades mais abertas, porém, nem sempre mais democráticas. Como resultado de um processo de urbanização crescente e contínuo que começou na última metade

\footnotetext{
${ }^{215}$ Noticias Diversas. O Estado de São Paulo, São Paulo, p. 2, 14 nov. 1902.

${ }^{216}$ Polvo Canadense é uma alusão muito utilizada pela historiografia paulistana em relação à Light and Power Company, detentora, dentre outros, da exploração do serviço de transporte público através dos bondes elétricos e da eletricidade.

${ }^{217}$ Parque Antarctica. O Estado de São Paulo, São Paulo, 8 nov. 1903. Noticias diversas, p. 2. O cinematógrafo pode ser considerado o início do cinema; porém, a perspectiva em que trabalha o movimento é fantasiosa, representando, portanto, imagens que, sobrepostas, geram a impressão do movimento.

${ }^{218} \mathrm{O}$ conceito de modernidade aqui empregado é aquele adotado no capítulo 1, conforme acepção de STERNE, Jonathan. The audible past: cultural origins of sound reproduction. Durham, N.C; London: Duke University Press, 2003. p. 9 [Tradução: Giuliana Lima, Juliana Pérez e Virgínia Bessa], apud PÉREZ GONZALES. A indústria fonográfica e a música caipira gravada. Uma experiência paulista (1878-1930). 2018. Tese (Doutorado) - Faculdade de Filosofia Letras e Ciências Humanas, Universidade de São Paulo, São Paulo.
} 
do século XIX e estendeu-se para além da metade do século XX, as mudanças em São Paulo seguiram uma tendência absorvida e reverberada pelas grandes metrópoles, como Nova York, Londres e Paris, a fim de acomodar as camadas mais pobres da população, sobretudo o nascente operariado industrial, no que se refere à oferta de divertimentos públicos. ${ }^{219}$ No campo musical, para que ocorressem as necessárias acomodações dessa população, foi imprescindível o desenvolvimento industrial, que possibilitou a modernização de toda uma série de instrumentos musicais que, de forma direta ou indireta, tornaram-se ferramentas da transição de um gosto musical provinciano para um novo gosto urbano junto aos grupos intérpretes de uma cultura também em transição. Dentre esses grupos, as bandas de música marcaram sólida presença.

A tecnologia ajudou a criar a ruptura entre o provinciano e o urbano e, nesse novo cenário, pode-se incluir o desenvolvimento das indústrias de instrumentos musicais, que aos poucos passaram a apresentar significativa melhora na matéria-prima de seu fabrico. As ligas de solda tornaram os instrumentos mais leves e versáteis. A invenção do sistema de válvulas e pistos para os referidos instrumentos - como os trompetes, ${ }^{220}$ trompas, trombones a pistos e, é claro, o souzafone - cuja invenção, pela tradição é atribuída a John Phillip Souza o "rei das marchas" - facilitou sobremaneira a execução e aprendizado, proporcionando um maior número de músicos para o naipe dos metais.

No processo de confecção das palhetas, seu refinamento de espessura possibilitou melhoras consideráveis na sonorização, o que iria um pouco mais tarde interessar muito à indústria da gravação. O desenvolvimento de novos projetos e desenhos industriais possibilitou maiores recursos e mais chaves para as clarinetas e flautas pelo sistema Boehm, ${ }^{221}$ bem como o uso em larga escala de saxofones, instrumento novo que produziu uma infinidade de possibilidades para transcrições de peças de orquestra para banda. O sensível aumento na qualidade das peças componentes (boquilhas, sapatilhas, etc.) desses instrumentos por meio de sua fabricação em tornos mecânicos deixou para trás os processos artesanais de confecção de outrora. Na percussão, as peles de animais também cederam lugar a novos materiais e os corpos de vários dos instrumentos dessa seção passaram a ser

\footnotetext{
${ }^{219}$ Cf. HOBSBAWM, Eric. A história social do jazz. Rio de Janeiro: Paz e Terra, 1990. p. 59-60.

${ }^{220}$ Devido a esse fato passaram a receber o segundo nome de pistão ou pistom.

221 SANTOS, João Alberto de Menezes dos. O clarinete: sistemas de chaves França/Alemanha. 2004. Dissertação (Mestrado) - Faculdade de Ciências Sociais e Humanas, Universidade Nova Lisboa, Lisboa. p. 4.
} 
construídos em metal mais leve e mais prático para sua execução em marcha, deixando no passado os pesados bumbos e taróis das mais diversas dimensões, antes confeccionados em madeiras pesadas.

Entre 1877 e 1900, nove fábricas de instrumentos musicais instalaram-se na cidade, além de 51 lojas de venda, conservação e manutenção de tais instrumentos que foram abertas em razão da demanda existente. ${ }^{222}$ Novos e melhores instrumentos produziram resultados tecnicamente mais aceitáveis para interpretações dos novos ritmos como cakewalk, ragtime, two-step e, posteriormente, jazz, que se juntaram no Brasil ao maxixe, aos schottisch, tangos, polcas e, é claro, às marchas e dobrados executados pelas bandas.

No primeiro período republicano, as relações dessa São Paulo com a música, como tratada neste capítulo, foram compostas por grupos e profissionais do ensino musical que construíram a paisagem sonora da cidade, dentro de uma perspectiva ambígua de tradição e modernidade, características próprias dos períodos históricos de transição. Dentre esses grupos estão orquestras que, incipientemente, tocavam nos teatros, aos poucos se organizaram em clubes musicais e sociedades, dando vazão, lá pela década de 1920, a corpos estáveis, embriões dos atuais conjuntos organizados que surgiriam no finalzinho dos anos 1930. Bandas que, em um número muito pequeno nos últimos suspiros do Império, saltaram para quase 90 quatro décadas depois, demonstraram os impactos de todo o processo dessa modernização e transição pelo qual passou esse universo musical urbano. Conjuntos de câmara que ofereceram seus serviços em cafés, bares, restaurantes e confeitarias promoveram a "boa música" em ambientes onde uma refeição poderia custar o equivalente a meio mês de salário de um músico dessas corporações musicais. Pianeiros de cinema e de lojas de instrumentos musicais que, além de experimentar as músicas para os clientes, tornaram-se verdadeiros showmen na arte de entreter. Seresteiros e músicos populares diurnos ou notívagos que transformaram os teatros e os cabarés em ambientes sonorizados; ${ }^{223}$ isso tudo

222 GONÇALVES, Janice. Música na cidade de São Paulo (1850-1900): o circuito da partitura. 1995. Dissertação (Mestrado) - Faculdade de Filosofia, Ciências Humanas e Letras, Universidade de São Paulo, São Paulo. Para as fabricas de instrumentos musicais, ver p.151-157.

${ }^{223}$ Este trabalho não pretende discutir o conceito nem as origens do músico popular de forma direta, tampouco suas diferenças (se é que houve) com os músicos eruditos. O conceito que se defende de músico popular neste texto é o de que popular foi o músico que não participou de um grupo que executava repertório sinfônico ou erudito. Portanto, nessa visão, o que o diferencia o músico popular é simplesmente o gênero executado e não sua formação. Para um melhor entendimento da formação do músico popular na cidade de São Paulo, ver: MORAES, José Geraldo Vinci de. Sonoridades paulistanas: final do século XIX ao início do século XX. Rio de Janeiro: Bienal, 1997. 
sem contar a presença de celeiros musicais nas associações de imigrantes e seus grupos de músicos, que trouxeram um novo "colorido musical" à cidade, formando um novo gosto e, ao mesmo tempo, reforçando os laços culturais com o passado daqueles que vieram para este lado do Atlântico.

Por fim, inquestionável ainda foi a participação da indústria fonográfica por meio do disco e de seus aparelhos reprodutores, em todo esse processo de massificação do disco. Em razão do devido avanço tecnológico, o disco desembocou nas prateleiras das lojas, pronto para o consumo do cliente que pudesse pagar. Nesse sentido, vale novamente lembrar que tudo isso somente foi possível e praticável na São Paulo do início do século XX em razão de uma conjuntura econômica favorável, consubstanciada pelo café.

Dessa forma, com a distribuição das corporações musicais pelos espaços públicos fechados e abertos, a paisagem da cidade de São Paulo aos poucos se converteu em uma massa sonora capaz de atender a quase todas as demandas musicais. $\mathrm{O}$ disco como segundo mediador retirou das ruas parte dessa massa sonora e a interiorizou nas residências e nas rádios, dando início à segunda etapa dos circuitos do som que se encerraria quando da massificação da radiofonia.

$\mathrm{Na}$ terceira fase dos circuitos do som, o retorno deste saindo do espaço privado para o espaço público foi indiscutivelmente mediado pelo rádio. Principal ferramenta de divulgação da indústria fonográfica, o rádio publicizou os repertórios gravados pelos conjuntos musicais e cantores durante as três primeiras décadas do século XX. O som que estava nos ambientes públicos passou ao ambiente privado das residências pelos discos, contudo, pouco tempo depois, saiu novamente do privado a caminho do público pelas rádios, as quais, divulgando essas gravações, fizeram o som atingir as massas. Porém, para compreendermos como foi possível essa mediação sonora entre disco e radiofonia, é necessário que saibamos como a indústria fonográfica se desenvolveu em São Paulo e absorveu a sonoridade das ruas da cidade executada através das bandas.

\section{As bandas e a indústria fonográfica}

As mudanças tecnológicas pelas quais o universo musical passou a partir do início do

século XX passaram a exigir também um outro tipo de qualificação dos músicos, que começaram a frequentar os estúdios de gravações. 
De acordo com o novo redimensionamento urbano apresentado no início do século XX, a cidade de São Paulo começou a apresentar também uma maior variedade de opções de lazer para sua população e, nesse cenário, mais opções de espaços para o consumo de música. Conforme a análise de José Geraldo Vinci de Moraes, ${ }^{224}$ houve a consolidação desses espaços, o que possibilitou música para todos os gostos e bolsos. Nesse sentido, os cilindros e, posteriormente, os discos entraram na competição com outras formas de entretenimento, disputando o dinheiro investido pelo consumidor nos circos, teatros e cinemas. Isso posto, o público para o qual a indústria fonográfica se estabeleceu na São Paulo no início do século $\mathrm{XX}$ era o mesmo que consumia os entretenimentos musicais desses espaços espalhados pela cidade. A diferença era apenas nas escolhas influenciadas pelo gosto e preferências culturais; ${ }^{225}$ mas, antes de seguir nessa discussão, é preciso compreender como esses itens de consumo de massa - discos e gramofones - foram apresentados e desenvolveram-se ao longo das três primeiras décadas do século XX. Para uma compreensão geral do cenário da indústria fonográfica, cabe ressaltar que a arte das gravações musicais está historicamente dividida nesse período em duas fases: a mecânica e a elétrica. ${ }^{226}$

A historiografia reporta que a primeira apresentação do fonógrafo na cidade de São Paulo ocorreu em 1878, um ano depois de sua invenção por Thomas Edison. ${ }^{227}$ Em $1^{\circ}$ de fevereiro de 1890 (doze anos após sua chegada à cidade), deu-se outra tentativa de divulgação do aparelho, narrada pelo Correio Paulistano. ${ }^{228} \mathrm{Na}$ ocasião, foram ouvidos fonogramas que continham as vozes de Pinheiro Chagas, que estava em Lisboa, uma cantora de fados não

\footnotetext{
${ }^{224}$ MORAES, José Geraldo Vinci de. Sonoridades paulistanas: final do século XIX ao início do século XX. Rio de Janeiro: Bienal, 1997. Passim.

${ }^{225}$ GONZALES, Juliana Pérez. A indústria fonográfica e a música caipira gravada. 2018. Tese (Doutorado) Faculdade de Filosofia, Letras e Ciências Humanas, Universidade de São Paulo, São Paulo. p. 151-152.

${ }^{226}$ A fase mecânica - também chamada de acústica - estendeu-se no Brasil entre os anos de 1902 a 1925 e trouxe, como características básicas, a utilização de estúdios em forma rústica de concha acústica. Utilizava-se uma peça em forma de funil pela qual, em sua maior abertura, o som entrava. Captando as ondas sonoras, estas eram transmitidas para uma membrana sensível, na qual, por um diafragma, gravava-se o som através de uma agulha que produzia sulcos em uma matriz sob a forma de cilindros ou discos, que posteriormente eram replicados em cópias que saíam para as vendas. Todo o processo se dava de forma mecânica, sem a interferência da eletricidade. A historiografia marca a fase elétrica no Brasil se iniciando em 1927, quando os meios de produção partiram para o uso de tecnologias que permitiram refinar as gravações. No entanto, o início desse processo se deu nos Estados Unidos pela Columbia Records em 1925. Dispensando o funil e utilizando um microfone, foi possível, em uma experiência inicial, a captação de um coro de 5.000 vozes, o que deu início a uma nova fase, em que se ampliou a capacidade do que se passou a gravar pelo trato eletromecânico da onda sonora e houve redução dos ruídos, utilização de microfones, amplificadores e alto falantes.

${ }^{227}$ O Phonographo e o microphone. Correio Paulistano, São Paulo, p. 2, 18 ago. 1878.

${ }^{228}$ O Phonographo. Correio Paulistano, São Paulo, p. 1, 2 fev. 1890.
} 
identificada, polcas executadas em Nova York, valsas tocadas em Antuérpia, duetos cantados em Milão, além das vozes de muitos "conhecidos" do Rio de Janeiro. A partir de então, as distâncias sonoras estavam encurtadas, uma vez que o aparelho recém-apresentado à cidade possuía a capacidade de reproduzir sons gravados em qualquer parte do planeta, bastando para isso acondicioná-los nos cilindros e, mediante seu funcionamento mecânico, reproduzilos. Ao que parece, o aparelho fez sucesso, mas não se tornou popular àquele momento (muito provavelmente por seu custo). Apesar da experiência ser registrada na imprensa da cidade, também ao que parece, adormeceu em seu lado prático para despertar apenas na década seguinte, pelas vias do gramofone, que substituiu esses primeiros aparelhos reprodutores de sons.

Mais de dois anos depois, em 3 de setembro de 1892, Frederik Figner trouxe a São Paulo outro fonógrafo e o apresentou aos jornais e demais personalidades no salão de fotografia Hosnen na rua de São Bento. O referido aparelho foi descrito pela imprensa como capaz de reproduzir "as mais leves particularidades do som", incluindo todas as entonações da voz humana e dos instrumentos musicais. Vale lembrar que uma primeira sessão de exposição (levada a cabo no dia anterior), havia ocorrido no Grande Hotel Paulista, quando foram reproduzidos os fonogramas de um discurso de Silveira Martins, várias peças musicais executadas para trompete e orquestra, além de trechos da Cavalaria Rusticana, Rigoleto e Ernani, entre outras. Todos os fonogramas foram ouvidos nitidamente, proporcionando um agradável divertimento aos presentes. ${ }^{229}$

No final da última década do século XIX e primeira do XX, a indústria fonográfica no Brasil desenvolveu-se, sobretudo pelas mãos de Frederik Figner, imigrante tcheco que, após se estabelecer no Rio de Janeiro inaugurando a Casa Edison, expandiu seus negócios para São Paulo com seus irmãos Gustavo e Emílio. ${ }^{230}$ Em princípio, a proposta era comercializar fonógrafos e cilindros, depois gramofones e discos. Nesse contexto, mais cilindros e discos do que os aparelhos propriamente ditos. Acima de tudo, no entanto, claramente estava posta uma questão de mercado: os aparelhos eram muito mais caros em

\footnotetext{
${ }^{229}$ Phonographo. O Estado de São Paulo, São Paulo, p. 1, 3 set. 1892.

${ }^{230}$ Como o escopo deste trabalho são as bandas de música, não entraremos nas questões das práticas comerciais da família Figner e da Casa Edison.
} 
termos de aquisição que seu subproduto: o disco. ${ }^{231}$ A primeira gravadora do país foi fundada no Rio de Janeiro em 1900 e, dois anos depois, uma série de gravações de músicas brasileiras eram iniciadas em um rústico e incipiente estúdio. Aquele espaço abriu-se para a participação de músicos, conjuntos, compositores e outras formações nessa ciranda fonográfica, o que contribuiu para consumo de massa da cultura musical nacional.

Uma das bandas que mais esteve presente nos estúdios da Odeon foi a do Corpo de Bombeiros do Rio de Janeiro, regida pelo maestro Anacleto de Medeiros. Como o princípio das atividades de gravação foi na capital federal, a quase totalidade dos fonogramas gravados no período que vai de 1902 até 1909 - ano em que, possivelmente, tenham ocorrido as primeiras gravações na cidade de São Paulo - registraram cantores, instrumentistas e bandas de música do próprio Rio de Janeiro. A qualidade técnica que levou Figner a conceder tantas oportunidades de gravação a essa banda carioca poderia não ter sido encontrada em suas primas paulistanas, à exceção talvez, das poucas que gravaram.

Ao que parece, a partir de 1909, São Paulo entrou no circuito, produzindo gravações de artistas e conjuntos locais pelas mãos dos irmãos Figner e da Odeon. ${ }^{232}$ Até o momento foram computados para o período 100 registros conforme apontam as tabelas 18 e 19 do Anexo I.$^{233}$ É fato que havia uma seletiva escolha de um pequeno número de bandas paulistanas para gravar.

O cenário perdurou até praticamente o final da década de 1920, quando outras gravadoras começaram a se instalar na cidade de São Paulo, quebrando o monopólio da Odeon. Contribuiu para tal quebra provavelmente uma certa falta de sensibilidade da matriz carioca em relação ao que se escutava em São Paulo. Um funcionário da filial da Odeon de São Paulo, em carta enviada à matriz da Casa Edison sediada na cidade maravilhosa, apontaria que o público de São Paulo era diferente daquele do Rio: sentia falta de ouvir as

\footnotetext{
231 Para uma compreensão bem mais abrangente das relações comerciais da indústria fonográfica, ver: GONZALES, Juliana Pérez. O Rio de Janeiro é apenas a capital Federal e não todo o Brasil. In: GONZALES, Juliana Pérez. A indústria fonográfica e a música caipira gravada. 2018. Tese (Doutorado) - Faculdade de Filosofia, Letras e Ciências Humanas, Universidade de São Paulo, São Paulo.

${ }^{232}$ Uma das exceções encontradas neste trabalho foi a música Feiticeira (sem autoria identificada), que destoando na data pode ter sido gravada entre 1902 e 1903 pela Banda de Música da Força Policial de São Paulo - traz o rótulo X-729 da gravadora ZON-O-PHONE. A respeito esse fato, voltaremos a ponderar no capítulo seguinte.

${ }^{233}$ Conforme as tabelas de discografia apontam, foram encontrados no total, 100 fonogramas gravados pelos seguintes conjuntos: Banda de Música da Força Pública do Estado de São Paulo, Banda Veríssimo Glória, Banda Ettore Fieramosca e Banda Giuseppe Verdi.
} 
vozes de sua própria cidade pelos gramofones. O referido público paulistano não queria ouvir grupos cariocas tocando o som de São Paulo. Para ele, "O Rio de Janeiro e[ra] apenas a Capital Federal e não todo o Brasil". ${ }^{234}$

Deixando um pouco a questão das gravações e entrando no cenário comercial, aos poucos, o comércio de discos e gramofones foi ganhando o gosto do ouvinte e outra possibilidade para aumentar as vendas. Isso gerava, para o empresário, a expectativa da venda imediata de seus discos, uma vez que, para compensar o investimento, eles não podiam encalhar. Nesse sentido, os grupos que gravaram em São Paulo (pelo menos, aqueles cujas gravações foram identificadas e listadas), possuíam estes dois pré-requisitos em comum: eram tecnicamente preparados e possuíam um público capaz de suportar a demanda de venda dos discos depois de prensados. Essa prática comercial pode ser justificada pela análise do rótulo 120.650 -Disco de 27 cm em 78 rpm gravado em junho de 1913 em São Paulo, que traz um tango intitulado Chic Club, de autoria de S. Vaz no lado A, e Sonho da Itália, uma marcha de autoria desconhecida no lado B. Conforme o catálogo da Odeon (gravadora detentora do rótulo), Chic Club fora interpretada por Veríssimo Glória, e Sonho da Itália, por Ettore Fieramosca. ${ }^{235}$ Assim se sucedeu com outros discos analisados em nossa pesquisa, ou seja, a partir da série 120.000 (1913), duas bandas passaram a compor o mesmo disco, sendo uma de cada lado, o que socializava seus custos e ampliava a probabilidade de vendagem do disco e, consequentemente, evitava seu encalhe nas prateleiras das lojas. No entanto, não se pode afirmar que essa prática tenha se tornado padrão, pois há discos (ainda que poucos), prensados e lançados na metade da década de 1910, em que o mesmo grupo interpreta obras em ambos os lados.

Retomando a questão das corporações musicais paulistanas e suas gravações, entre os dias 16 e 26 de junho de 1913 foram gravadas 82 ceras da série 120.000. A prática nos leva

\footnotetext{
${ }^{234}$ Essa frase fora elaborada por um funcionário de nome Ernesto [ilegível] em uma carta endereçada para Fred. Figner, num contexto em que o referido funcionário reclamava, junto à matriz da Casa Edison do Rio, que em São Paulo o público era diferente daquele da capital federal. Esse público paulista gostaria de ouvir o som de São Paulo e de seus grupos musicais através do disco e não grupos cariocas. Por isso, propunha algumas mudanças nas relações comerciais entre os dois estabelecimentos e suas práticas de gravações. São Paulo, 25 de janeiro de 1926. In: FRANCESCHI, Humberto. A Casa Edison e seu tempo. Rio de Janeiro: Sarapuí, 2002. apud GONZALES, Juliana Pérez. A indústria fonográfica e a música caipira gravada. 2018. Tese (Doutorado) - Faculdade de Filosofia, Letras e Ciências Humanas, Universidade de São Paulo, São Paulo. p. 178. A frase também nomeia a Parte I de sua tese.
}

${ }^{235}$ FRANCESCHI, Humberto M. A Casa Edison e seu tempo. Rio de Janeiro: Sarapuí, 2002. p. 180. 
a crer que gravações anteriores podem ter ocorrido em solo paulistano, conforme indicado anteriormente pelo rótulo X-729 da Zon-O-Phone, em que o grupo da Força Policial havia gravado Feiticeira, entre 1902 e 1093. O mesmo também sugerem colecionadores de discos em 78 rpm. ${ }^{236}$ A série 108.000 da Odeon, por exemplo, pode mesmo ter sido gravada em 1909 em solo paulistano. Nela, foi possível encontrar 22 fonogramas da Força Policial, além de 20 outros distribuídos entre as bandas Ettore Fieramosca e Veríssimo Glória. No lote da série 120.000 da Odeon (gravado, sabidamente, em São Paulo entre 16 e 26 de julho de 1913), estão incluídos novamente fonogramas da Ettore Fieramosca, da Força Policial de São Paulo e Veríssimo Glória. ${ }^{237}$ Outra banda cujas gravações foram localizadas em nossa pesquisa foi a Giuseppe Verdi de São Paulo; metade das gravações levantadas pertencem à fase mecânica (selo Gaúcho de 1916) e a outra metade está situada já na fase elétrica, a partir de 1927 (selo Phoenix 1932). Os dados das Tabelas 18 e 19 trazem o levantamento geral dos fonogramas localizados e que foram gravados por corporações musicais da cidade de São Paulo entre 1902 e 1932, mas não necessariamente na cidade de São Paulo.

Do material fonográfico compilado resultaram 29 arquivos sonoros em três Cds que o acompanham esta pesquisa como anexo. ${ }^{238} \mathrm{O}$ primeiro deles contém 13 faixas gravadas pela Banda de Música da Força Policial do Estado de São Paulo (entre 1902 e 1913); o segundo, nove faixas gravadas pela Ettore Fieramosca de São Paulo (1909 e 1913); e o terceiro, mais sete faixas, sendo cinco gravadas pela Veríssimo Glória (1913 e 1920) e duas pela Giuseppe Verdi de São Paulo (1932). ${ }^{239}$ Nessas faixas, é possível perceber auditivamente as dificuldades do processo de gravação para compor os primeiros registros sonoros, revelando um alto nível de ruído que se somava ao som e que, dessa forma, às vezes descaracterizava algumas obras e até mesmo seus respectivos gêneros.

O levantamento indica aproximadamente 96 rótulos de discos gravados dessas corporações musicais entre 1902 e 1932. Foram localizados 38 fonogramas da Força Pública de São Paulo que resultaram em 38 discos, pelos selos Odeon, e um único com selo da Zon-

\footnotetext{
${ }^{236}$ Miguel Nirez, por exemplo, aponta que algumas gravações em solo paulistano datam de 1909.

${ }^{237}$ FRANCESCHI, Humberto M. A Casa Edison e seu tempo. Rio de Janeiro: Sarapuí, 2002. p. 181.

${ }^{238}$ E que podem ser escutados também em http://www.memoriadamusica.com.br/site/index.php/texto-e-audio

${ }^{239}$ Os fonogramas das bandas da Força Policial de São Paulo, Ettore Fieramosca e do maestro Veríssimo Glória foram digitalizados e gentilmente cedidos pelo Instituto Moreira Salles, no Rio de Janeiro. (Coleção José Ramos Tinhorão - Acervo Instituto Moreira Salles - Rio de Janeiro - RJ). Os fonogramas da Giuseppe Verdi foram digitalizados e gentilmente cedidos pelo colecionador de discos em $78 \mathrm{rpm}$ Miguel Braghioni, da cidade de Porto Ferreira (SP).
} 
O-phone. ${ }^{240}$ Da banda Ettore Fieramosca, foi possível localizar 30 fonogramas gravados em 30 rótulos diferentes pelo selo Odeon. Da corporação musical do Maestro Veríssimo Glória, 25 fonogramas foram encontrados, gravados em 24 discos pelos selos Odeon e Phoenix ; ${ }^{241}$ e da Giuseppe Verdi de São Paulo, foram localizados seis fonogramas, gravados em quatro rótulos distintos pelos selos Gaúcho e Arte-phone. ${ }^{242}$

Não se pode inferir que o conjunto das informações levantadas nesta pesquisa alcance toda a produção musical das bandas na cidade nas primeiras três décadas do século XX. É possível que outros grupos tenham gravado durante o período que cobre este estudo, sem, contudo, terem se revelado pelas fontes disponíveis neste momento. Tais incertezas geram lacunas que, com o tempo, talvez sejam preenchidas, trazendo luz sobre essas dúvidas que pairam sobre a produção fonográfica das bandas paulistanas. Por exemplo, uma das incertezas é: qual foi o impacto da indústria para essas instituições? E outra é: como o disco interferiu nos circuitos do som, do sentido público para o privado e, posteriormente, do privado retornando para o público?

Refletindo sobre a primeira questão, há que se considerar que muitos foram os impactos advindos da indústria sobre os grupos musicais, mas, para efeito de concisão neste estudo, o caminho escolhido para a percepção de alguns desses impactos será percorrido pelo viés do repertório. A coleta e análise de programas de concerto entre 1902 e 1930 pode levar a algumas conclusões sobre o porquê a corporação musical da Força Pública tocou e o que tocou durante esse período. Como vimos no capítulo 1 e no anexo deste trabalho, as fontes revelaram que o que era executado nos concertos públicos constava em sua grande parte de

\footnotetext{
${ }^{240}$ Os discos gravados e lançados até o ano de 1909 contêm apenas uma faixa musical da Banda da Força em um de seus lados. Em seu outro lado, costumeiramente havia discursos, poemas e toda sorte de textos gravados pelos mais diversos motivos. Não foi possível encontrar os selos da série 108.000 da Odeon, que contempla esse período. Já a partir de 1913 (série 120.000 da mesma gravadora), ocorrem lançamentos de discos nos quais ambos os lados contêm fonogramas gravados por grupos diferentes, sendo um determinado grupo em um dos lados e outro noutro lado.

${ }^{241}$ A maior parceira dos discos da banda de música do maestro Veríssimo Glória foi a banda Ettore Fieramosca. Essa dupla rendeu nada menos que sete dos discos gravados e localizados na pesquisa. Há também discos prensados com o grupo da Força e aquele do maestro Veríssimo Glória, bem como há a parceria entre a Ettore Fieramosca e a Banda da Força. A diferença entre o número de rótulos (discos) e fonogramas é encontrada no disco de rótulo 120.643, que contém, em ambos os lados, gravações feitas pela Veríssimo Glória. Dos discos pesquisados pertencentes à fase mecânica, esse foi o único caso em que o mesmo grupo gravou em ambos os lados.

${ }^{242}$ Os rótulos 4.047 e 4.108 (gravadora Arte-Phone) trazem também gravações da Giuseppe Verdi de São Paulo em ambos os lados. Contudo, a datação já se enquadra na fase elétrica (1932), representando uma tendência que se tornaria prática a partir da década de 1930.
} 
transcrições de peças oriundas de óperas, sinfonias e demais formas eruditas, apresentadas nas diversas tabelas que contemplaram seus programas, ${ }^{243}$ porém como veremos no próximo capítulo, o que foi para os discos, não era o que se tocava nos concertos.

Discos, na verdade, não passavam de suportes, contendo informações sonoras que deveriam ser reproduzidas por um aparelho decodificador, no caso, os gramofones. No afã de introduzir o público nessa nova era, na qual a reprodução sonora tornou-se possível, $O$ Estado de São Paulo de 20 de março de 1910 trazia um anúncio das Casas Phoenix de Gustavo Figner, situadas nas ruas de São Bento 38-B e 15 de Novembro 27, proclamando que essas eram as únicas representantes no Brasil da Columbia Phonograph Company Gen’1 de Nova York. Tentando seduzir o cliente, alegava que seu gramofone era "o melhor de todos, o que prova as inúmeras e grandes recompensas que obteve em todas as exposições onde se apresentou em concorrência com os demais gramofones americanos”. No entanto, os preços variavam de acordo com o modelo: Clímax $100 \$ 000$ (cem mil réis); Novo Royal $120 \$ 000$ (cento e vinte mil réis); Novo Sterling 200\$000 (duzentos mil réis); Novo Imperial $240 \$ 000$ (duzentos e quarenta mil réis); e Grande Ópera $350 \$ 000$ (trezentos e cinquenta mil réis). ${ }^{244}$

Nessa lista, dois detalhes chamam a atenção: o primeiro é que o mesmo anúncio trazia a informação de que o aparelho era vendido sem os discos, que deveriam ser adquiridos separadamente. Conforme afirmativa de Juliana Perez Gonzales, ${ }^{245}$ para os fabricantes, era mais interessante a venda dos discos, que, apesar de bem mais baratos, vendiam em maior quantidade do que os gramofones; e o segundo é que o salário de um músico da Banda de Música da Força Pública, em 1910, era algo em torno de $102 \$ 000$ (cento e dois mil réis, conforme a Tabela 5). Seguindo essa lógica, para adquirir o mais básico dos gramofones, o músico seria obrigado a gastar todo o seu salário. Dessa forma, semelhantemente a qualquer processo industrial desenvolvido a partir do século XVIII, quem lucrava em toda a cadeia produtiva (discos e gramofones) eram os detentores daqueles meios de produção e não o

\footnotetext{
243 De uma forma aberta, os programas de concertos e gráficos apresentados no capítulo anterior trazem os indicadores necessários para essa discussão, que será retomada em maior profundidade no capítulo 3, quando serão analisados os repertórios da Banda da Força Pública na última década do século XIX e nas três primeiras do século XX, além dos efeitos da indústria fonográfica sobre essa corporação especificamente.

${ }^{244}$ Columbia. O Estado de São Paulo, São Paulo, 20 mar. 1910. Annuncios, p. 9.

${ }^{245}$ GONZALES, Juliana Pérez. A indústria fonográfica e a música caipira gravada. 2018. Tese (Doutorado) Faculdade de Filosofia, Letras e Ciências Humanas, Universidade de São Paulo, São Paulo. p. 56.
} 
trabalhador (músico) que os produzia. Potencializando ainda mais essa questão, em outro anúncio do mesmo jornal datado de 14 de setembro do mesmo ano de 1910, outra fabricante (VICTOR) anunciava seus modelos a preços entre 40\$000 (quarenta mil réis) e 1:000\$000 (um conto de réis). A esses valores, quase dez salários do músico de um dos grupos que gravava os discos seriam necessários para a compra do melhor gramofone.

A estratégia comercial e a ideia propagada pela VICTOR, a partir da segunda década do século XX, passou a ser a de que, adquirindo seus produtos, o consumidor poderia ter a corporação que quisesse sendo executada no móvel de sua sala, à hora em que bem entendesse, para seu deleite e de seus convidados.

Faculta-vos o meio de apreciar as mais famosas orchestras e bandas em vossa casa.

De nenhuma outra maneira podeis ouvir as mais celebres Bandas do mundo - A Banda do Corpo de Bombeiros (do Brazil) a Banda da Polícia da cidade do México, a Banda da Real Marinha de Italia, a Banda da Garde Républicaine de França, a Banda de Souza, a Banda da Marinha dos Estados Unidos, a Banda de Pryor, a Banda do Theatro Alla Scalla, a Orchestra Bosc de Paris, a Magnifica Orchestra Victor etc., etc. ${ }^{246}$

Curiosas, no entanto, foram as formas chamadas de "escuta alternativa" por Juliana Perez Gonzáles. ${ }^{247}$ Essa escuta era, na verdade, o aluguel tanto de gramofones quanto de discos a preços variados, gramofones esses que podiam ser levados para as casas por uma, duas ou mais semanas, e devolvidos após a sessões auditivas individuais ou coletivas. Tal prática perdurou, ao que parece, até a segunda década do século XX. Dividindo com a vizinhança a possibilidade de uma escuta compartilhada dos maiores sucessos do momento, o operariado conseguia ter acesso à fonografia e, ao mesmo tempo, dispendia pouco dinheiro, transformando a escuta em prática social compartilhada.

Passados cinco anos após a data da primeira tomada de preços, é possível entender que o processo de produção em série trilhou o caminho natural da indústria de massa, ou seja, os preços começaram a dar indícios de barateamento, talvez pelo excesso de produção que gerava muita oferta e ainda pouca procura em razão de seu preço. Contudo, pouca coisa havia mudado na vida daqueles que produziam a riqueza dessa indústria, ainda privados de

\footnotetext{
${ }^{246}$ A Victor. O Estado de São Paulo, São Paulo, 22 fev. 1912. Annuncios, p. 11.

${ }^{247}$ GONZALES, Juliana Pérez. A indústria fonográfica e a música caipira gravada. 2018. Tese (Doutorado) Faculdade de Filosofia, Letras e Ciências Humanas, Universidade de São Paulo, São Paulo. p. 155-158.
} 
desfrutar de sua própria sonoridade. Em outro anúncio publicado em O Estado de São Paulo de 6 de junho de 1915, pela mesma Casa de Gustavo Figner, o gramofone Phoenix 105 Jumbofone, que era vendido em outras lojas por 105\$000 (cento e cinco mil réis), estava sendo liquidado para as festas de Santo Antônio, São João e São Pedro pelo preço de 57\$000 (cinquenta e sete mil réis). Há, ainda no mesmo anúncio, a ideia de preços no varejo dos discos circulantes naquele momento. Discos Duplos Odeon cujo valor regular era 5\$000 (cinco mil réis) eram vendidos àquele momento por 2\$000, 2\$500 e $3 \$ 000$ (dois mil a três mil réis). Discos Columbia, também duplos, eram liquidados de $5 \$ 000$ (cinco mil réis) por $1 \$ 500$ (mil e quinhentos réis). ${ }^{248}$

Considerando que o salário do músico da Banda da Força Pública do Estado (padrão para nossas análises) não sofreu alteração entre 1911 e 1919, conforme apontam os dados das Tabelas 5 a 7, mantido a um valor de $102 \$ 000$ (cento e dois mil réis), a "voz do dono" 249 continuava enfrentando muita dificuldade para se ouvir na mídia mecanizada. Com um pouco mais da metade de seu salário, o músico poderia comprar agora um gramofone. Fora das liquidações e a preços regulares, o restante desse salário daria para comprar nove discos e o aluguel ficaria sem ser pago, ele andaria a pé o mês inteiro, sem poder tomar o bonde, nem poderia comprar remédios em casos de doença, e sua família morreria de fome.

Vê-se, portanto, que, embora a indústria sofra um processo lento e gradual de massificação, o aumento da produção e da tecnologia, ao que parece, não acompanhou a queda desses preços nem promoveu a acessibilidade à fonografia das classes menos favorecidas em São Paulo. No entanto, uma análise mais apurada entre os preços de gramofones e discos revela que as três primeiras décadas do século XX produziam uma tendência muito lenta à baixa nos preços desses itens. Assim, é possível perceber de certa forma a popularização do consumo da música gravada, que desenvolveu o mercado fonográfico estabelecido a partir dos anos $1900 .{ }^{250}$ Essa afirmação todavia, só pode ser validada sob a ótica da nascente classe média urbana e das elites da cidade, longe, portanto, do operariado e dos músicos que gravavam o que se vendia, conforme a referência do salário

\footnotetext{
${ }^{248}$ Musica alegria musica. O Estado de São Paulo, São Paulo, 6 jun. 1915. Annuncios, p. 12.

${ }^{249}$ BUARQUE, Chico. A voz do dono e o dono da voz. Intérprete: Chico Buarque. In: CHICO BUARQUE. Almanaque. Rio de Janeiro: Philips, 1982.

${ }^{250}$ GONZALES, Juliana Pérez. A indústria fonográfica e a música caipira gravada. 2018. Tese (Doutorado) Faculdade de Filosofia, Letras e Ciências Humanas, Universidade de São Paulo, São Paulo. p. 150.
} 
do músico da Banda da Força Pública. Mas, para atender a esse crescente mercado fonográfico, a cidade foi se adaptando e, para se ter uma ideia da expansão do mercado fonográfico, entre os anos de 1900 e 1929, foram localizados mais de 40 estabelecimentos que comercializavam gramofones e discos novos em de São Paulo. 251

Ao longo da terceira década do século XX, outros mecanismos chegaram complementando as tecnologias que surgiam, como foi o caso do aperfeiçoamento da vitrola $^{252}$ e os discos que, ainda em $78 \mathrm{rpm}$, passaram a ser gravados, a partir de 1927, sob um novo método. Desenvolvidas pela mediação de aparelhos como o microfone, as gravações a partir de então passaram a resultar na busca de alta fidelidade, captando muito melhor os sons e consequentemente reproduzindo-os de melhor forma também. O problema, no entanto, era que cada vez mais esse processo concentrava os meios de produção nas mãos de grandes gravadoras, ${ }^{253}$ explorando essas "vozes" quer fossem naturais, quer dos instrumentos (força de trabalho lato sensu) pagando pouco ao contratá-las para gravar e realizar shows e ganhando muito ao vende-las ao público. Camila Koshiba Gonçalves comenta a respeito do mercado das gravadoras e dos sons no Rio de Janeiro e em São Paulo no início dos anos 1930, já nesse contexto de uso da eletricidade:

Assim, a gravação elétrica não foi unicamente uma mudança na técnica de registro sonoro. Configurou-se em um amplo movimento tecnológico, corporativo e de transformação no padrão auditivo dos ouvintes, que se tornaria a base da estratégia das gravadoras ao longo de todo o século XX. Desta forma, a música gravada deve ser percebida como produto de uma empresa, com estrutura organizativa, estratégias de implantação e de atuação, cujo objetivo é protagonizar o processo de produção elétrico e difusão via mercado da música em uma sociedade. ${ }^{254}$

\footnotetext{
${ }^{251}$ GONZALES, Juliana Pérez. A indústria fonográfica e a música caipira gravada. 2018. Tese (Doutorado) Faculdade de Filosofia, Letras e Ciências Humanas, Universidade de São Paulo, São Paulo. p. 135.

${ }^{252}$ Inventada em 1906 pela Victor Talking Machine, a Victrola era um gramofone que se tornou popular em pouquíssimo tempo por seu baixo preço e por ser compacto e portátil. Em 1911, ela já era vendida em São Paulo. Em 1927, o aperfeiçoamento da Victrola trouxe uma maior possibilidade de juntar as tecnologias das gravações às de reprodução do som. A amplificação do som através de um alto-falante permitiu uma estabilidade mais eficaz para a reprodução e um controle de intensidade jamais visto anteriormente. Não por acaso, todos os toca-discos a partir de então passaram a ser reconhecidos pelo nome vitrola (sem a letra $c$, originária de sua fabricante, Victor).

${ }^{253}$ Refiro-me aqui às grandes gravadoras, como, a princípio, a Odeon, Arte-fone, CBS-Columbia, RCA-Victor, EMI e, posteriormente, a Phillips, Tapecar, Polydor, Som Livre, Sony etc.

${ }^{254}$ GONÇALVES, Camila Koshiba. Vitrola paulistana pelos olhos e ouvidos de um basbaque-andarilho In: MORAES, José Geraldo Vinci de; SALIBA, Elias Thomé (Org.). História e música no Brasil. São Paulo: Alameda Casa Editorial. 2010. p. 356-7.
} 
Dentro dessa lógica, a técnica e a estética iniciaram uma disputa cada vez mais acirrada, levantando inúmeras questões ainda presentes na Academia. Dentre elas, a pergunta sobre se a técnica interferiu na estética, conforme questionamento levantado por Sophie Maisonneuve. ${ }^{255} \mathrm{O}$ processo de produção gerou mudança na escuta fonográfica na São Paulo do final dos anos 1920 para início dos anos 1930. Formou-se uma nova sensibilidade no público que recebeu esse som gravado de forma elétrica, colocando a tecnologia no centro desse processo. Se a escuta fonográfica está em um ambiente de práticas sociais e culturais, a tecnologia não se torna senhora da escuta, embora esta faça parte e seja apurada a cada dia por aquela, mas, sim, essa escuta passa a ser construída ao longo do tempo, tendendo a deixar vestígios dessa temporalidade e todas as características inerentes a seu tempo.

Nesse embate entre a técnica e a estética, é preciso pensar no refinamento dos meios de gravação (novamente, a passagem do mecânico para o elétrico), como a melhor captação do áudio, e o aperfeiçoamento da fabricação, como a melhora nas matérias-primas para o fabrico dos discos, equalização e a formatação da produção em discos de 3 e 4 minutos, padronização das 78 rotações, etc. para se compreender melhor a massificação. Aos poucos e em razão também desse processo industrial, essa escuta fonográfica passou a ganhar caráter de patrimônio e referência cultural como foi o caso da música caipira de São Paulo que a partir de então passou a ser registrada nos discos e pôde ser ouvida em qualquer lugar do país. Surgiu, assim, a figura do melômano que "toca o disco": um outro tipo de músico que não lê uma partitura, mas que, aos poucos, vai entendendo tudo de música. Seguindo essa lógica desenvolvimentista, nos anos 1930, as grandes gravadoras estrangeiras passaram a dominar de vez o mercado paulistano. Empresas como RCA-Victor, Columbia e Odeon não demoraram a travar fortíssimas ligações com o mundo do rádio, da publicidade e da imprensa escrita, criando uma rede simbiótica na qual todos os elementos seriam imprescindíveis uns aos outros.

Por fim, essa escuta gerou uma possibilidade criativa, intermediada pelas práticas profissionais de um novo mundo que estava sendo gestado graças a dois fatores fundamentais: a técnica e a estética, sendo aquela representada pelo desenvolvimento

${ }^{255}$ MAISONNEUVE, Sophie. L'invention du disque, 1877-1949. Paris: Archives Contemporaines Editions, 2009. Passim. 
tecnológico dos meios de produção musicais e a estética representada pela formação do gosto que consumia os produtos gerados por essa indústria fonográfica. Nesse contexto, pode-se inferir que a técnica pôde e interveio na estética em nome do mercado, construindo todos esses rótulos para a música paulista por meio dos selos das gravadoras.

Apesar de toda a problematização da indústria, da mudança de escuta e das tecnologias, há ainda que se refletir sobre a segunda questão levantada: como o disco interferiu nos circuitos do som? Do ambiente público, o som foi para o privado; posteriormente, saiu do privado e voltou ao ambiente público, ainda que por mediadores diferentes a partir da radiofonia. 
Capítulo 3

\section{A trajetória da Banda da Força Pública}


No domingo de 23 de maio de 1875, o cronista anônimo do Folhetim de A Província de São Paulo perguntava à população: “Cidade ou Orchestra?” Para o autor, a pergunta tinha sentido, pois ele constatava uma tendência crescente na cidade de grupos musicais. Alegava que nunca São Paulo havia estado "tão cheia" de música, listando os diversos conjuntos existentes: Companhia Lyrica; a Companhia de Zarzuelas; Banda de Música do Corpo de Permanentes; Lyra Paulistana; Euterpe Commercial; Coral Allemã; Banda de Música dos Menores Artífices; e Banda de Música Italiana. Além deles, o autor comentou a presença de pianos particulares e sanfonas, lembrou os órgãos, o cantochão e os sinos das igrejas, citou as ladainhas, os assobios dos moleques, os passarinhos, os galos, os grilos, os sapos e as rãs e, finalmente, os murmúrios da brisa. Todo esse quadro servia para reforçar seu argumento de que a cidade vivia uma época especial, inundada de sons e músicas de várias origens, que formavam a paisagem sonora paulistana à época. Encerrando a nota, dizia que, caminhando nesse ritmo, dentro de pouco tempo, a fala da cidade seria cantada e os cidadãos andariam guiados pelos compassos musicais. ${ }^{256}$

De fato, a vida musical da cidade desenvolveu-se bastante a partir da década de 1870, mas estava longe do vaticínio lançado pelo colunista. Mesmo com o impacto das novidades sonoras, a cidade ainda tinha uma vida cultural e musical limitada, com poucas atividades e conjuntos permanentes. Entre os raros conjuntos musicais existentes naquela época, estava exatamente a Banda de Música dos Permanentes. ${ }^{257}$ Deste modo, o objetivo deste capítulo é trazer ao leitor um olhar mais próximo e crítico sobre a vida dessa banda, abordando sua criação, desenvolvimento, músicos, regulamentos, maestros, repertório e sua participação na indústria fonográfica, estendendo-se por um período que abrange o século XIX até a década de 1930.

Embora haja indícios de sua preexistência no Quartel do Convento do Carmo, que abrigava os Permanentes, ${ }^{258}$ desde 1832, e notícias de atividades informais internas durante a década de 1840, a Banda foi oficializada somente em 1857.259 Para entender melhor a

\footnotetext{
${ }^{256}$ Cidade ou orchestra? A Província de São Paulo, São Paulo, 23 mai. 1875. Folhetim, p. 1.

${ }^{257}$ Houve várias mudanças nos nomes da instituição entre os séculos XIX sde XX. Usaremos os seguintes critérios de nomenclatura: Guarda Municipal Permanente, Corpo Municipal Permanente, Corpo Policial Permanente, Força Militar de Polícia, Força Policial e Força Pública do estado de São Paulo.

${ }^{258} \mathrm{O}$ nome Corpo Municipal Permanente foi adotado em razão dessa tropa viver permanentemente às expensas do erário público, sendo uma corporação de efetivo fixo, diferente das que a sucederam.

${ }^{259}$ Lei n. 24 de 7 abr. 1857. São Paulo: ALESP, São Paulo, 1857.
} 
trajetória desse conjunto, que teve presença ativa e vida longa na história da cultura musical paulistana, é preciso antes compreender seu papel na instituição que gerou condições para sua formação, crescimento e manutenção, a Guarda Municipal Permanente.

\section{A banda e a instituição militar}

Em outubro de 1831, foi aprovada a lei de criação das Guardas Municipais para a Capital Federal e, opcionalmente, para as outras Províncias do Império. Em São Paulo, a organização de sua Guarda Municipal ocorreu em dezembro de 1831, sob a presidência do Brigadeiro Rafael Tobias de Aguiar. Seu efetivo inicial previa dois corpos, o de infantaria, com 100 membros, e o de cavalaria, com 30. Sua organização era militar e a função era a de auxiliar da Justiça, com natureza estritamente policial; ${ }^{260} \mathrm{em} \mathrm{1844,} \mathrm{o} \mathrm{nome} \mathrm{da} \mathrm{Guarda} \mathrm{foi}$ alterado para Corpo Municipal Permanente, e foram reorganizados os efetivos e a estrutura administrativa da instituição. ${ }^{261}$ Certamente, a organização da Guarda Municipal não previa de início a formação e manutenção de uma banda de música. De acordo com Laura Della Mônica, as origens da banda na Guarda Municipal Permanente remontam ao ano de 1843, quando o major ajudante Joaquim Antônio Fernandes comunicou ao Presidente da Província que havia na corporação alguns membros que tocavam instrumentos de sopros. ${ }^{262} \mathrm{O}$ major pediu então autorização para criação de uma pequena banda de cornetas para ajudar nos rituais militares internos. Desse modo, a primeira formação do conjunto tinha como finalidade atender às demandas da rotina que a vida dos quartéis colocava aos soldados, musicando quase todas as solenidades e exercícios de ordem unida, marchas e eventos realizados dentro da caserna. A Banda nasceu, portanto, essencialmente, para cumprir as

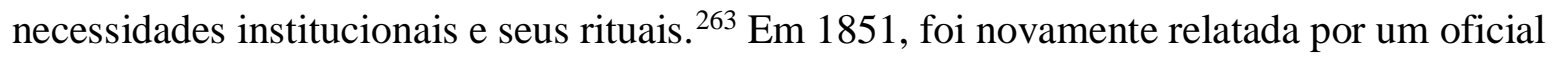
encarregado de inspecionar o Corpo a existência informal dessa Banda, ${ }^{264}$ quando, finalmente, foi requerida sua oficialização em 1856 pelo comandante da corporação, tenente coronel Joaquim de Souza Guimarães Cananéia. Em sua solicitação, pediu que os soldados

\footnotetext{
${ }^{260}$ FERNANDES, Heloisa Rodrigues. Política e segurança. São Paulo: Alfa-ômega, 1974. p. 71. grifo nosso. ${ }^{261}$ Lei n. 19 de 27 fev. 1844. ALESP, São Paulo, 1844.

${ }^{262}$ DELLA MONICA, Laura. História da Banda de Música da Polícia Militar do Estado de São Paulo. São Paulo: Edanee, 1975. p. 25.

${ }^{263}$ ANCHIETA TORRES, José de. Origem da banda de música. Militia, São Paulo, n. 28, mai.-jun. 1952. p. 15-17.

${ }^{264}$ DELLA MONICA, Laura. História da Banda de Música da Polícia Militar do Estado de São Paulo. São Paulo: Edanee, 1975. p. 26.
} 
fossem empenhados apenas no serviço musical, sendo dispensados das demais funções policiais. Finalmente, em 1857, foi editada a lei que regulamentou a Banda de Música do Corpo de Permanentes, custeada pela Província e composta de um sargento mestre ${ }^{265}$ e 17 músicos pagos pelos soldos da instituição:

Art. 5.o - Fica approvada desde já a banda de musica existente no corpo de municipaes permanentes, sendo ella composta de um mestre, com a graduação e soldo de $1^{\circ}$ sargento, e dezesete musicos com o soldo e mais vantagens dos soldados, não podendo ser empregados em serviços estranhos a musica, e sendo estas dezoito praças além do numero fixado no artigo primeiro. Não se dará, porém outro augmento de despeza além da de soldo e vantagem referida. ${ }^{266}$

Logo após a oficialização, ela foi instalada em uma das salas do Convento do Carmo, ${ }^{267}$ e imediatamente começou a enfrentar dificuldades no recrutamento de músicos para compor seus quadros. Na realidade, o alistamento na Guarda não era tão atraente, já que as profissões urbanas, como ferrador, seleiro ou sapateiro, pagavam salários melhores. Além disso, as circunstâncias internas da instituição durante a década de 1860 e a eclosão da Guerra do Paraguai também criaram muitas dificuldades. A Guerra impôs modificações no funcionamento do corpo militar, atingindo também a Banda, que, junto às tropas da Guarda, foram para o teatro de operações. Laura Della Mônica, por exemplo, informa os músicos militares que seguiram com a Banda para acompanhar os conflitos da guerra:

Mestre de Música: José Pinto Tavares/ [...] $1^{\circ}$ Sargento Manoel Avelino da Silva/ $2^{\circ}$ Sargento Francisco de Assis Azevedo/ $3^{\circ}$ Sargento José Alves de Oliveira/ soldados Pedro Rodrigues da Silva, Manuel Francisco das Dores, Marçal Jerônimo Machado, João Tavares, José Antônio de Oliveira, Vicente Ferreira, João de Deus Sacramento, Luiz Antônio de Campos Melo, Jesuíno de Cássia Lustosa, José Pedro Alexandrino de Paula, Jesuíno Rosa Pinto Tavares, João Carlos Aranha, Luiz Alves da Cruz e Francisco Jorge Pereira.

\section{BANDA DE CORNETEIROS:}

\footnotetext{
${ }^{265} \mathrm{O}$ termo mestre para o condutor das bandas descende de mestre-de-capela. Aos poucos, derivou para Diretor de Banda e finalmente, no século XX, maestro de banda, de acordo com ALMEIDA, Aloísio. O Folclore da Banda de Música. Revista do Arquivo Histórico da cidade de São Paulo, São Paulo, n CLXXVI, p. 45-79, jan.mar. 1969.

${ }^{266}$ Lei n. 24 de 7 abr. 1857. ALESP, São Paulo, 1857.

${ }^{267}$ O Convento de Nossa Senhora do Carmo (esquina da avenida Rangel Pestana com a rua do Carmo, onde hoje se encontram instalados o Poupatempo Sé e a Secretaria Estadual da Fazenda) foi a primeira sede a abrigar a Guarda Municipal Permanente, que ali permaneceu até o ano de 1892, quando da construção do Quartel da Luz (atual Batalhão Tobias de Aguiar) situado na avenida Tiradentes, seu primeiro quartel próprio.
} 
Corneteiro-mor: João Nepomuceno de Camargo e Silva.

Cornetas: Benedito do Espírito Santo, Domingos Vieira, Manoel de Jesus, Joaquim Bazílio e José Maria Corrêa. ${ }^{268}$

Com o fim da guerra, em 1870, houve nova reestruturação na Força Policial, a qual alcançou também a Banda. No retorno, os músicos começaram a ser empenhados em outras atividades, como a guarda do quartel, o rancho, faxina e demais funções internas, o que dificultou as atividades musicais. Em contrapartida, a Banda cresceu de 17 para 21 músicos. ${ }^{269}$ A década de 1880 continuou apresentando dificuldades para sua sobrevivência, uma vez que foram diminuídos os investimentos na Banda e o soldo do músico de $3^{\mathrm{a}}$ classe era o pior pago dentro da instituição. ${ }^{270}$ Por essas razões, nessa época, apareceu uma “caixinha” para aquisição e reparo de instrumentos musicais. Curiosamente, no final da década, o número do efetivo subiu para 24 músicos, sendo distribuídos em dez primeiras classes, oito segundas classes e seis terceiras classes, além do mestre. ${ }^{271}$

Em síntese, após um período de dificuldades no tocante às finanças e efetivo, a Banda havia crescido. Entretanto, como veremos a seguir, seu andamento de crescimento sairia de um tranquilo Largo e seguiria para um Andante, colorido a partir da República.

\section{Andante republicano}

Com a chegada da República, a Força Pública e consequentemente sua Banda passaram por profundas transformações. Como se sabe, as mudanças desenhadas pela nova Constituição republicana deram aos estados autonomia para implementar suas políticas regionais, entre elas as de segurança pública. A antiga corporação militar demorou cerca de uma década para se estabilizar como instituição dentro dessa nova perspectiva republicana. E certamente a Banda também sofreu com essas transformações.

A Lei n. 17 datada de 14 de novembro de $1891^{272}$ trouxe mudanças no sentido organizacional da Força Pública, detentora da Banda de Música. Ela previa em seu Quadro

\footnotetext{
268 DELlA MONICA, Laura. História da Banda de Música da Polícia Militar do Estado de São Paulo, São Paulo: Tipografia Edanee, 1975. p. 29-30.

${ }^{269}$ Lei n. 64 de 10 abr. 1870. ALESP, São Paulo, 1870.

${ }^{270}$ Lei n. 27 de 10 mar. 1888. ALESP, São Paulo, 1888.

${ }^{271}$ As leis estaduais que respaldam essa narrativa são respectivamente: Lei n. 42 de 31 mar. 1882, Lei n. 33 de 30 mar. 1883, Lei n. 54 de $01^{\circ}$ abr. 1884, Lei n. 67 de 26 mar. 1885, Lei n. 78 de 3 mai. 1886 e Lei n. 29 de 24 mar. 1887.

${ }^{272}$ Lei n. 17 de 14 nov. 1891. Fixa a Força Pública do Estado para o ano de 1892. ALESP, São Paulo, 1891.
} 
Particular de Organização (QPO) $)^{273}$ que os $1^{\circ}$ e $2^{\circ}$ Corpos Militares de Polícia conteriam bandas de música, sendo destacados para sua composição um mestre de música (na graduação de sargento) mais 12 músicos de primeira classe e 12 músicos de segunda classe, além de um corneta-mor. Somando o efetivo, cada banda possuía [ou possuiria] 26 figuras, incluindo o maestro (cada unidade), que duplicadas (duas bandas no total) perfaziam um número de 52 músicos na instituição. Como a $1^{\mathrm{a}}$ Companhia do $2^{\circ}$ Corpo Militar de Polícia fora extinta em 1892, a banda pertencente àquela companhia foi transferida para o $1^{\circ}$ Corpo, e anexada à já existente, formando assim uma banda de aproximadamente 50 músicos, ${ }^{274}$ sediados então no Quartel da Luz, que abrigava o $1^{\circ}$ Batalhão. Dessa Banda de Música do $2^{\circ}$ Corpo Militar de Polícia que fora extinta, descenderia Benedicto de Assis Lorena, que, tendo ingressado na corporação em 1888, tornar-se-ia seu maestro, após a reforma de Antão em 1924.

Em 1892, outra lei mudou o nome da Força Militar de Polícia para Força Pública, transformando os antigos Corpos Militares em Batalhões de Infantaria. ${ }^{275}$ Conforme esse documento, a Banda de Música passava a pertencer ao $1^{\circ}$ Batalhão, sediado a partir de então na Avenida Tiradentes.

Como o efetivo e as despesas orçamentárias da Força eram revistos anualmente pelo executivo, a Lei n. 97-A de 21 de setembro de 1892 reduziu o número de músicos da Banda. Em vez de congregar os 52 músicos anteriormente fixados pela Lei n. 17 de 1891, a partir de então, a Banda passou a contar com um mestre de música, 12 músicos de primeira classe, 12 músicos de segunda classe, sendo acrescidos oito músicos de terceira classe, perfazendo um total de 33 figuras. ${ }^{276}$ Talvez como solução paliativa para não se perder o excedente de músicos, o $§$ único do artigo 13 da Lei n. 97-B previa ainda que os outros Corpos ou Batalhões poderiam organizar Bandas de Música, contanto que tal organização não gerasse ônus ao

\footnotetext{
${ }^{273}$ Documento militar que descreve o número de cargos e suas respectivas funções existentes dentro de cada Corpo ou fração dele (Regimentos, Batalhões e Companhias, etc.).

${ }^{274}$ Em seu livro História da Banda de Música da Polícia Militar do Estado de São Paulo,1975. p. 38, Laura Della Mónica alega que, com a junção das duas bandas, o número de músicos subiu para 64 figuras. Trata-se de um equívoco, uma vez que cada banda poderia conter no máximo 26 figuras.

275 Aqui se pode notar que, à medida em que a República avançou, a militarização da Força Policial seguiu o mesmo ritmo, transformando aos poucos esta instituição híbrida (policial e militar) mais em militar do que policial. O fato de a Força Policial adquirir esse caráter militar favoreceu a emergência e manutenção de sua banda de música: não fosse o caráter militar, não haveria função para uma banda de música dentro da instituição policial uma vez que, dentro do quartel, a Banda se prestava a treinamentos de ordem unida junto à tropa.

${ }^{276}$ Lei n. 97A de 21 set. 1892. Fixa a Força Pública do Estado para o ano de 1893. ALESP, São Paulo, 1892.
} 
erário público. ${ }^{277}$ Essa fórmula remetia às antigas receitas de formação das bandas da Guarda Nacional, segundo as quais os oficiais dos próprios Batalhões custeavam suas despesas de formação e manutenção, conforme relata Jeane Berrance de Castro. ${ }^{278}$ Os registros documentais apontam para a possibilidade de criação de outras bandas, com fortes indícios de que essas práticas realmente tenham existido. Em sua autobiografia, Joaquim Antão Fernandes narra que, a convite do tenente coronel Vicente Lucidoro de Oliveira, comandante do $5^{\circ}$ Batalhão, aceitou reger a banda de música daquela unidade em 1894, o que confirma assim sua existência, ${ }^{279}$ e lá permaneceu até o final de 1895, quando foi promovido a alferes.

Um indicativo de tal prática foi a criação de uma Banda efêmera no $2^{\circ}$ Batalhão de Infantaria sediado na cidade de Jundiaí - SP, sem ônus para o estado, conforme anúncios publicados insistentemente por quase 2 meses em O Correio Paulistano, entre novembro e dezembro de $1892^{280}$. Outro indício de formação de Bandas em outras Unidades pode ser encontrado, conforme apontado no capítulo 1. Em O Correio Paulistano de 03 de março de 1892, o jornal informava a criação de uma banda de música no $5^{\circ}$ Corpo Militar de Polícia 281 cujos instrumentos foram doados pelo sr. Abílio Soares ${ }^{282}$. Isto ratifica a possibilidade e a ideia de criação de mais Bandas dentro da permissividade apresentada pela legislação. Esta seria a Banda a que Antão foi convidado a se tornar regente até $1895^{283}$.

Em 1896, surgia um novo regulamento para a Força Pública ${ }^{284}$ e nele, as funções de mestre de banda e de inspetor da música, passaram a ser tratados, ainda que ,de forma incipiente, por meio de seus artigos 156 a 161, mas, com o advento da Lei $n^{\circ}$ 491, publicada no apagar das luzes daquele mesmo ano de 1896, novamente, a Força reorganizou-se. A partir de então, o número de componentes da Banda de Música foi aumentado para um mestre, 10

\footnotetext{
${ }^{277}$ Lei n. 97B de 21 set. 1892. Organiza a Força Pública do Estado para o ano de 1893. ALESP, São Paulo, 1892.

${ }^{278}$ CASTRO, Jeanne Berrance de. A música na Guarda Nacional. O Estado de São Paulo, São Paulo, 31 mai. 1969. Suplemento Literário, p. 4.

${ }^{279}$ FERNANDES, Joaquim Antão. Minha autobiografia. São Paulo, s/editor, 1943 p. 11. Mimeografado.

${ }^{280}$ A sede do $2^{\circ}$ Batalhão funcionou na cidade de Jundiaí de 1892 a 17 de abril de 1896, quando foi transferida para Campinas. Em 20 de abril de 1897, sua sede retornou para a cidade de São Paulo, porém, ao que parece, sua banda de música já estava desativada.

${ }^{281} \mathrm{O} 5^{\circ}$ Corpo militar de polícia era comandando naquele momento pelo Ten. Cel. João de Souza Machado.

${ }^{282}$ Nova banda de música. Correio Paulistano, São Paulo, p. 1, 3 mar. 1892.

${ }^{283}$ Os anos de 1893 a 1895 transcorreram sem maiores novidades para a legislação organizacional da instituição, uma vez que a Lei n. 186 de 22 de agosto de 1893, a Lei n. 273 de 23 de junho de 1894, e a Lei n. 354 de 28 de agosto de 1895 mantiveram quase as mesmas condições impostas em 1892.

${ }^{284}$ Decreto n. 348 de 6 abr. 1896. Dá regulamento à Força Pública do Estado. ALESP, São Paulo, 1896.
} 
músicos de primeira classe, 12 músicos de segunda classe e 12 músicos de terceira classe, perfazendo um total de 35 figuras $^{285}$. Em 20 de março de 1897, outro diploma legal veio regrar de forma mais contundente a vida da Banda dentro da instituição, dando-lhe um caráter definitivo de serviço profissional:

\section{CAPITULO V}

Banda de Musica

Do inspector

Artigo 44. - Será nomeado um official que saiba musica para inspector da banda de musica, sem prejuíso do seu cargo, e incumbe-lhe:

$\S 1^{\circ}$. - Assistir aos ensaios e comparecer no logar em que tenha a musica que tocar.

$\S 2^{\circ}$. - Fazer pedido do que for necessário relativamente ao instrumental e musicas e solicitar os necessários concertos.

$\S 3^{\circ}$. - Escripturar e trazer em dia o mappa da carga e descarga do material da banda.

$\S 4^{\circ}$. - Do produto das tocatas particulares distribuir dous terços aos músicos proporcionalmente as classes e recolher o terço restante à respectiva caixa. ${ }^{286}$

O fato de, a partir de então, haver um funcionário específico e comissionado para a função de inspetor da Banda de Música que necessariamente deveria "saber música" representava o início da construção de uma perspectiva de carreira para os músicos que ingressavam nas Bandas da Força. Cabe ressaltar que, antes da edição do Decreto, tal função era exercida por qualquer oficial da instituição, independente do posto (alferes a coronel), como função cumulativa a outra que o referido oficial já vinha desenvolvendo, porém, sem a necessidade desse oficial possuir conhecimentos musicais. O Decreto, portanto, passa a considerar a função de inspetor da banda tão profissional dentro do corpo quanto qualquer outra, atribuindo à referida função isonomia e o mesmo respeito de que gozavam todas as demais nas armas de infantaria e cavalaria, ainda que fosse em caráter cumulativo. Neste caso, a inovação veio em razão do pré-requisito de ocupação da função: oficial detentor de conhecimentos musicais. Mais avanços nesse sentido são observados nos artigos seguintes do mesmo Decreto:

Do mestre e musicos

\footnotetext{
${ }^{285}$ Lei 491 de 29 dez. 1896. Reorganiza a Força Pública do Estado. ALESP, São Paulo, 1896.

${ }^{286}$ Decreto n. 437 de 20 março de 1897. Dá Regulamento à Força Policial do Estado. ALESP, São Paulo, 1897.
} 
Artigo 45. - O mestre da musica será tirado dentre os músicos de $1^{\text {a }}$ classe sob proposta do respectivo inspector, ouvido o fiscal, e terá a graduação de $1^{\circ}$ Sargento, cumprindo-lhe:

$\S 1^{\circ}$. - A direcção da banda em todas as occasiões de serviço e em todos os logares em que ella tiver de tocar, dando sempre parte ao inspector da maneira porque os músicos procederem.

$\S 2^{\circ}$. - Vigiar pelo asseio e comportamento dos músicos, assim como pela conservação do uniforme, armamento, equipamento e instrumentos que lhes forem distribuídos, participando immediatamente ao inspector as faltas que encontrar.

$\S 3^{\circ}$. - Ensaiar a banda uma vez por dia, das 10 horas a 1 da tarde.

$\S 4^{\circ}$. - Propôr ao commandante, por intermédio do inspector, sendo ouvido o fiscal, as praças no caso de serem aprendizes.

Artigo 46. - O mestre da musica será substituído no seu impedimento ou ausência pelo contra-mestre, indicado pelo inspector dentre os músicos de $1^{a}$ classe, que usará dos distinctivos de $2^{\circ}$ Sargento e se encarregará especialmente do ensino dos aprendizes.

Artigo 47. - A banda de musica será sujeita à disciplina da $1^{\text {a }}$ companhia do $1^{\circ}$ batalhão de infantaria ${ }^{287}$.

Como é possível notar, entre os artigos 45 a 47, havia o regramento para o mestre e os músicos. Ainda na perspectiva de formatação da carreira profissional, o músico possuía a oportunidade de entrar na banda como aprendiz (ficando sob os cuidados do contramestre) e ascender às graduações de terceira, segunda e primeira classes, quando então teria a possibilidade de concorrer à função de contramestre. Uma vez nela, o próximo passo seria o de mestre de música (cujo pré-requisito era também ser músico de primeira classe), que o tornaria regente do conjunto. Acima disso, já nos postos de alferes ou tenente (oficial) o músico tornar-se-ia, respectivamente, o auxiliar e o inspetor de música da Força.

Nessa organização, três pontos chamam a atenção: o primeiro é que essa foi uma das primeiras e bem-sucedidas estruturações de carreira interna da instituição. ${ }^{288} \mathrm{O}$ segundo é que, a partir de então, somente músicos poderiam exercer as funções de inspetor da Banda ${ }^{289}$, mestre de música e contramestre, o que evitava que oficiais e praças de outras armas fossem nomeados para tanto e fortalecia politicamente não apenas os laços profissionais, mas sobretudo o desenvolvimento dos trabalhos musicais, retirando a Banda de Música da

\footnotetext{
${ }^{287}$ Decreto n. 437 de 20 mar. 1897. Dá Regulamento à Força Policial do Estado. ALESP, São Paulo, 1897.

${ }^{288}$ A carreira de oficial da Força Pública estruturada de alferes a coronel, somente seria consolidada a partir de 1910 graças à primeira missão francesa conforme veremos adiante.

${ }^{289}$ Embora o Art. 44 da Lei 491 de 28 dez. 1896 trazia que o inspetor da banda, seria um oficial "que saiba música", não havia ainda naquele momento, a perspectiva de concurso para o provimento do referido cargo e respectiva função. A ideia do legislador, era a de que, como pré-requisito para o exercício do cargo, o oficial deveria ser músico, o que já representou um grande avanço conforme nosso pensar.
} 
subordinação de profissionais essencialmente militares, e criando uma forma de representatividade direta perante o comando geral, por meio da figura do oficial músico nas funções de auxiliar e inspetor. O terceiro ponto foi a escala de ensaios diários prédeterminada pelo próprio regulamento, conforme o $\S 3^{\circ}$. Por meio de ensaios cotidianos de pelo menos três horas, a Banda - à semelhança de suas coirmãs do Exército, Marinha ou demais instituições militares de outros estados, como a Banda do Corpo de Bombeiros do Distrito Federal nas mãos do maestro Anacleto de Medeiros - não apenas ganhou plenas possibilidades de adquirir um bom nível técnico, mas também se tornou capaz de interpretar o repertório composto majoritariamente de obras transcritas dos programas de óperas.

Mais um ponto curioso é que quase um ano antes, em 1896, haviam sido publicadas as exigências para ingresso como músico na Força: os candidatos deveriam ter bom comportamento, serem zelosos, inteligentes, bastante aptos para a música, além de saber ler e contar, ${ }^{290}$ esta última uma inovação para a instituição. A alfabetização requerida para os músicos quando de seu ingresso representa, em certa perspectiva, uma clara valorização profissional, pois até 1943 a instituição mantenedora, a Força Pública, não exigiria a alfabetização e o domínio das quatro operações aritméticas para ingresso em seus quadros ${ }^{291}$, conforme aponta o coronel PM Eduardo Assumpção. ${ }^{292}$ Conclui-se assim que, desde 1896, pressupunha-se que o músico ingressante tivesse um nível intelectual superior àquele de praça de infantaria, ou cavalaria. Por outro lado, é importante ressaltar que tal exigência não representava a exclusão de negros e mestiços nos quadros da Banda, uma vez que o nível da prova era bastante elementar, exigindo apenas a leitura e não a escrita.

Feitas essas considerações, voltemos a analisar cronologicamente o percurso da Banda. No início de 1898, Antão foi enviado à Itália por proposta de Eugênio Egas, ${ }^{293}$ a fim

\footnotetext{
${ }^{290}$ Decreto n. 348 de 6 abr. 1896. Art. 162. São Paulo: ALESP, São Paulo, 1896.

${ }^{291}$ A partir de 1910, essas exigências passam a ser pré-requisitos para o soldado que, postulando uma promoção a cabo, se submetesse a um concurso interno, porém não quando de seu ingresso.

292 ASSUMPÇÃO, Eduardo. Evolução técnico-cultural, determinação e desenvolvimento do PM. 1984. Monografia (Conclusão do CSP-I/84). Polícia Militar do Estado de São Paulo, São Paulo.

${ }^{293}$ Eugênio Egas, natural de Iguape (SP), nasceu em 15 de maio de 1863 e faleceu em São Paulo em 29 de junho de 1956. Formado pela Faculdade de Direito do Largo de São Francisco (USP), foi membro do Instituto Histórico e Geográfico de São Paulo. Foi eleito por três mandatos consecutivos para a câmara dos deputados de São Paulo entre os anos de 1895 e 1901. No momento citado por Joaquim Antão, Egas exercia mandato como Deputado Estadual e o Presidente do Estado era Peixoto Gomide, que sucedeu a Campos Salles. Em suas memórias, Antão narra, no entanto, que Campos Salles estava no cargo. Se as memórias de Antão estiverem corretas, é provável que as negociações sobre sua ida tenham se dado em 1897 e seu embarque tenha ocorrido somente em abril do ano seguinte (1898), quando Peixoto Gomide já havia tomado posse.
} 
de conhecer e estudar as bandas italianas, tanto civis quanto militares nas cidades de Roma, Milão e Veneza. Permaneceu em solo europeu até maio de 1889 e conseguiu angariar o conhecimento necessário, que utilizou a partir de sua chegada para a organização das bandas de música da Força. Ao regressar, foi convidado a apresentar um plano de trabalho, pois, conforme os desacertos institucionais ocorridos em 1898, os músicos haviam se dispersado após sua partida para a Itália. Convite aceito, Antão reorganizou uma banda com quase 60 figuras nos moldes da Banda Municipal de Roma. A banda foi dividida em duas seções de 30 músicos cada, além do mestre de música, formatadas para estarem prontas a atenderem os serviços militares e da comunidade e, quando necessário, serem reunidas para grandes apresentações, conforme o modelo-piloto que já experimentara a partir de 1895. O custo do projeto, no entanto, foi a desativação de outras bandas existentes na corporação, restando doravante apenas estas duas, comandadas pelo inspetor e maestro Antão.

Vale lembrar ainda que, conforme apontado no capítulo 1, embora tratando-se de corporações irmãs subordinadas ao mesmo chefe, a Força Pública e o Corpo de Bombeiros possuíam bandas de música distintas. Quando a Banda do Corpo de Bombeiros foi desativada, seu mestre de música Salvador Chiarelli, veio para a Banda da Força. ${ }^{294}$

Em 1899, novas leis abriram mais vagas para músicos ingressarem na Força Pública, ${ }^{295}$ o que aparentemente demonstra uma certa preocupação com a política de reposição desses conjuntos musicais. Pela nova disposição, a instituição passou a comportar dois mestres de música e 60 figuras comandadas por um tenente inspetor. Os músicos estavam distribuídos em dois conjuntos sediados no Quartel do $1^{\circ}$ Batalhão de Infantaria. ${ }^{296}$ A estrutura previa a possibilidade de organização em duas Seções que, quando tocavam separadamente, eram regidas cada uma por seu respectivo mestre. A ideia de Antão nasceu em 1895, quando este somou forças com as bandas existentes para os grandes concertos e apresentações. A partir desse momento, ganhou força e legitimidade, vigorando na prática até o final da década de 1960. Em uma perspectiva mais ampla, é possível atribuir à legislação

\footnotetext{
${ }^{294}$ Salvador Chiarelli foi o oficial maestro substituto de Benedicto de Assis Lorena da Banda da Força Pública em 1926 quando este faleceu. Chiarelli comandaria a banda de 1926 a 1931.

${ }^{295}$ Lei n. 652 de 16 de agosto de 1899. Fixa a Força Pública para o anno de 1900. ALESP, São Paulo, 1889. Lei n. 653 de 16 ago. 1899. Reorganiza a Força Pública do Estado. São Paulo: ALESP, São Paulo, 1899.

296 Nesse momento, os Batalhões sediados na cidade de São Paulo eram o $1^{\circ}$ Batalhão, situado à Avenida Tiradentes (atual Batalhão Tobias de Aguiar), o $4^{\circ}$ Batalhão também situado à Avenida Tiradentes (em endereço diverso do $1^{\circ}$ ) e o $5^{\circ}$ Batalhão situado ao Convento do Carmo (sede inicial do Corpo de Permanentes).
} 
de 1899 a criação de uma Unidade de música de forma efetiva ${ }^{297}$, com estrutura de comando (um inspetor, dois mestres de música e músicos), própria de instituições militares, bem como duas bandas de médio porte, contendo 30 músicos cada.

Em 1900, o efetivo da Banda de Música passou a partir daquele momento a contar com um tenente ${ }^{298}$ na função de inspetor de música, quatro músicos de classe distinta (na graduação de $2^{\circ}$ sargentos), 12 músicos de primeira classe, 20 músicos de segunda classe e 24 músicos de terceira classe. ${ }^{299} \mathrm{O}$ número de figuras se manteve, portanto, em 60. Era, assim, uma grande banda, com boas possibilidades de formar duas com 30 figuras cada. Notese que, para o oficial, a partir de então, já não caberia apenas o posto de alferes, mas sim o de tenente, o que representava outro ganho hierárquico na carreira.

A partir de 1901, o status de independência se instaura de forma mais sólida na Banda. ${ }^{300}$ Publicava-se o Decreto n. 874, que tratava especificamente desse Corpo musical que era, em síntese, um documento de 25 artigos regrando definitivamente a vida dessa corporação dentro da Força Pública. Era um primeiro regulamento cuja essência inspiraria mais tarde a formulação do regimento interno da Banda. No referido Decreto, os efetivos foram mantidos (60 músicos), assim como a organização em duas Seções distintas com a possibilidade de tocar em conjunto para grandes concertos ou em separado para pequenas apresentações. A grande imprensa registra inúmeras retretas no Jardim do Palácio (pela $1^{\text {a }}$ Seção da Banda) e no Jardim da Luz (pela $2^{a}$ Seção) no mesmo dia e horário. Cada Seção deveria conter, pelos menos, quatro aprendizes para a renovação dos quadros da Banda, podendo serem admitidos praças de quaisquer nacionalidades, desde que demonstrassem gosto pela música. No tocante às solicitações, o regramento previa que, fora dos atos oficiais, as Seções não poderiam tocar sem remuneração, exceto nas festas cívicas ou de caridade, desde que devidamente autorizadas pelo governo. Nessas ocasiões, as autorizações para essas apresentações deveriam ser expedidas (sempre por escrito) pela Secretaria da Justiça ou pelo Presidente do Estado, seguindo o fluxo burocrático ao comandante da Força e, finalmente, ao inspetor da Banda. Quanto aos ensaios, o documento delegava ao inspetor a

\footnotetext{
${ }^{297}$ Unidade, para a Administração militar, corresponde à fracão de tropa equivalente a Batalhão.

${ }^{298}$ Atualmente oficial no posto de $1^{\circ}$ tenente.

${ }^{299}$ Lei 722 de 16 out. 1900. Fixa a Força Pública do Estado para o ano de 1901. ALESP, São Paulo, 1900.

${ }^{300}$ Decreto n. 874 de 9 fev. 1901. Dá instrucções à banda de musica da Brigada Policial do Estado. ALESP, São Paulo, 1901.
} 
responsabilidade de traçar um cronograma diário de atividades, excetuando-se às segundasfeiras, possivelmente pelo fato de os músicos gozarem folga nesse dia da semana, em decorrência de serviços prestados aos sábados e domingos, quando a demanda aumentava consideravelmente.

Quanto às atribuições pessoais, o decreto iniciava pelo inspetor, indicando que, sendo nomeado pelo governo, deveria também ser oficial conhecedor de música, encarregado e responsável direto pela Banda perante o comando. Entre essas atribuiçõos, a maioria concentrava-se na parte técnica profissional, como a fiscalização, o ensaio e a regência da Banda, bem como cuidar do repertório, organizando os programas de concerto e seu arquivo. Gozando de certa autonomia, o inspetor podia utilizar uma verba de até $100 \$ 000$ mensais para despesas diversas, prestando contas ao comandante da Força. Deveria ainda propor ao mesmo comandante a nomeação de mestres de música para as Seções mediante concurso organizado entre os músicos de classe distinta e os de primeira classe. ${ }^{301}$

Graduados a partir de então como $1^{\circ}$ sargentos, aos mestres de música, praticamente competia a condução das Seções quando em separado. Como cada Banda possuía seu mestre, elas também apresentavam vidas autônomas, às quais o inspetor quase não tinha acesso cotidiano, exceto quando ambas se juntavam e passavam a ser coordenadas por ele. Quanto aos músicos de classe distinta (imediatamente abaixo do mestre e os mais altos na hierarquia dos músicos), estes passaram a ser graduados como $2^{\circ}$ sargentos, e os de primeira a terceira classes eram praças de bom comportamento, que eram promovidos à medida que houvesse vagas, por proposta do inspetor ao comandante da Força Pública. Todos os músicos eram obrigados a comparecer aos ensaios e apresentações a ressarcir o estado quando do dano de seu instrumento (em caso de sua negligência), ter sempre o instrumento limpo, zelar pelo asseio na sala de música e prestar obediência ao inspetor e aos mestres.

Pelo mesmo Decreto n. 874 de 9 de fevereiro de 1901, foi constituído o Arquivo da Banda de Música, composto dos hinos nacionais, marchas e dobrados militares, e de danças, obras dos grandes mestres e composições de quaisquer gêneros que o inspetor julgasse

\footnotetext{
301 Os concursos para mestre de Banda passaram a ocorrer pautados em conteúdos de conhecimentos elementares da arte musical e prova prática do ensaio e regência.
} 
conveniente. ${ }^{302}$ Para o início do Arquivo da Banda de Música, o Governo do estado, bancou de pronto a aquisição das partituras dos hinos das nações amigas em 1901.

O Decreto previa que a verba para a organização do Arquivo fosse fornecida pela caixa da música (da própria Banda); e pelo governo quando a caixa não tivesse fundos. ${ }^{303} \mathrm{~A}$ caixa da música era um fundo de reserva constituído de $30 \%$ das somas recebidas por todas as apresentações e concertos (quer em conjunto ou separadamente pelas seções). Era gerenciada pelo inspetor e destinada ao pagamento de despesas diversas das Bandas. Outros $60 \%$ da arrecadação eram rateados entre os músicos, conforme os critérios da hierarquia. Os $10 \%$ restantes eram do inspetor. Todas as arrecadações e suas consequentes distribuições deveriam ser documentadas e apresentadas em prestação de contas ao comando do $1^{\circ}$ Batalhão, mediante relatórios mensais.

Finalmente, o referido Decreto estipulava os valores, para a contratação dos serviços das Seções da Banda de Música, ficando definido que, para apresentações na capital, seria cobrada uma taxa de $200 \$ 000$ quando juntas e 100\$000 por Banda em separado. Quando a apresentação ocorresse fora do município de São Paulo, os valores subiriam para 500\$000 pelo conjunto das Seções ou $250 \$ 000$ quando viajasse apenas uma das Seções. ${ }^{304}$ Diante dessa organização, estrutura de pessoal, arquivo, repertório, arrecadação financeira e política de contratação e reposição de músicos, a Banda encontrava-se respaldada institucional, jurídica, artística e financeiramente. Essas condições a grande maioria de suas concorrentes na cidade nem de longe havia conseguido até aquele momento e muitas jamais conseguiriam. A Banda estava pronta, portanto, para enfrentar o século que começava, alojada em amplas, ventiladas e novas instalações na sede do $1^{\circ}$ Batalhão de Infantaria, ${ }^{305}$ em condições plenas de desenvolvimento técnico, fornecidas por seus horários de ensaio e todo o apoio logístico promovido pela legislação. A partir de então, amadureceu o entendimento de que, quando a

\footnotetext{
302 A partir dessa nova formatação, o Arquivo da Banda de Música passou a ser responsabilidade direta do inspetor.

303 Para o início do Arquivo da Banda de Música, o Governo do Estado de São Paulo bancou de pronto a aquisição das partituras dos hinos das nações amigas em 1901.

304 Esses valores, quando em município diverso da cidade de São Paulo, eram diários. Caso as bandas permanecessem por mais de um dia, os valores, portanto seriam acrescidos de $100 \%$ por dia de permanência na localidade solicitante. É preciso esclarecer também que as despesas com alimentação, transporte e hospedagem, se fosse o caso, seriam sempre pagas pelo solicitante (rotina que se observa ainda nos dias atuais) e tais procedimentos dependeriam da aprovação do Presidente do Estado ou do Secretário de Justiça, transmitida ao comandante da Força.

${ }^{305}$ Quartel da Luz na avenida Tiradentes, de onde só sairia na década de 1950.
} 
Banda da Força tocava, havia a necessidade de se qualificar qual de suas Seções estava tocando, ou se as bandas estavam juntas, formadas como "uma grande banda"; neste caso, cabendo a regência sempre ao inspetor de música tenente Antão. ${ }^{306}$

Novas alterações no campo jurídico chegaram para a Força Pública do Estado de São Paulo a partir de 28 de setembro de 1905. A legislação que tratou do assunto trouxe uma nova reorganização: criou novos postos e funções, classificou e qualificou uma série de novos profissionais como oficiais auxiliares dentro da corporação, sendo estes: cinco médicos, um auditor, um engenheiro eletricista, um administrador das linhas telegráficas, um feitor, dois guarda-fios, um veterinário, um picador e um mestre de música. ${ }^{307}$ Equiparando as funções e os ofícios entre si de uma perspectiva institucional, o que passou a prevalecer dentro da questão hierárquica não foi mais a ascensão de carreira, mas, sim, a área de formação do profissional. As estruturas de carreira, ensino e escolas, formas de ingresso, uniformes, insígnias e técnicas profissionais seriam introduzidas e coordenadas pela Missão Militar Francesa a partir de maio de 1906; e os reflexos de sua influência sobre a corporação, que se estenderam à Banda de Música, foram inegáveis, como veremos a seguir.

\subsection{Mudanças no repertório}

Decorridos mais de 30 anos após a criação da Banda da Força Pública, um crítico apontava observações no repertório da corporação. De certo modo, o crítico musical de $O$ Correio Paulistano, cujo pseudônimo de Figarote, servia para encobrir as opiniões do compositor Alexandre Levy, ${ }^{308}$ apontava para esse panorama de mudanças, colaborando para acelerá-las. Iniciava suas observações, dizendo que a Banda dos Permanentes já não era mais a mesma de outrora, tendo sido reduzida a um "realejo". Insistia que seu repertório em 1890 se tornara frívolo, composto de uma coleção de tangos e polcas (que apenas bastavam para aguçar nos ouvintes suas ideias pornográficas), além de dobrados. Em especial, um

\footnotetext{
${ }^{306}$ A partir de então, os anúncios de apresentações feitos pela imprensa qualificavam que: A $1^{\text {a }}$ Seção da Banda da Força Pública tocará no jardim da Luz, ou: A banda completa da Força Pública tocará no Jardim do Palácio sob a regência do tenente Antão.

${ }^{307}$ Lei n. 958 de 28 set. 1905 . Art. $8^{\circ}$. São Paulo: ALESP, 1905.

${ }^{308}$ Figarote era, na verdade, o pseudônimo do compositor Alexandre Levy (1864-1892), que publicou várias críticas às companhias de teatro musicado, bem como a grupos musicais no jornal O Correio Paulistano. MORAES, José Geraldo Vinci de; FONSECA, Denise Sella. A música em cena na Belle Epoque paulistana. Revista IEB, São Paulo, n. 54, set.-mar. 2012. p. 107-138.
} 
extraído do tema $O$ Guarany que, conforme o cronista, era digno de lástima. ${ }^{309}$ Pedia então para que a direção da Banda acabasse com aquelas caricaturas musicais, solicitando peças de um mais alto valor musical. Queria ouvertures, óperas, operetas, fantasias, pot-pourris que, instrumentados para banda de música, poderiam ocupar os programas de concerto dessa corporação em vez daquilo que constantemente se tocava. Insistia nessa questão do repertório arguindo, ainda, se as valsas de Strauss e de Waldteufel não seriam preferíveis a "qualquer cateretê com o competente chocalho". Queria dizer que não era a intenção banir do repertório da Banda as polcas, dobrados e tangos, pois alguns deles de fato representavam nossa "música popular", porém alegava que a rua era o lugar certo para a execução do dobrado quando em marcha; não um coreto, lugar de música mais “elevada”. Defendia também que a Banda deveria - à semelhança da banda italiana Umberto I e quase todas as bandas europeias - publicar com antecedência nos jornais da manhã o programa a ser executado em suas apresentações, a fim de que os convidados já tivessem prévio conhecimento do que seria ouvido. A Banda dos Permanentes não anunciava o que tocava. Por fim, questionava se a Banda deixava de fazê-lo por vergonha, uma vez que, quando se apresentava a Umberto I no Jardim do Palácio, o recinto ficava repleto, e, quando a dos Permanentes se apresentava, poucos corriam ao local para ouvir seus tangos e polcas. ${ }^{310}$

Seguindo o conselho do crítico, o caminho do repertório, ao que parece, de fato mudou. Se a Banda entre 1857 e 1890, data da crítica de Figarote, tocou tangos, polcas, maxixes, cateretês e toda sorte de "música popular", a partir da década de 1890, tomou outro rumo: o repertório passou a ser publicado nos jornais, anunciado sempre de forma antecipada, e passou a dar prevalência à transcrições de músicas de concerto, óperas etc., como destacado no capítulo 1. Vale lembrar ainda que a mudança solicitada demorou cerca de 15 anos (1880 a 1895) e demandou o trabalho de três maestros (Caetano Tibúrcio de Oliveira Rosa, Bernardo Jorge da Costa e Joaquim Antão Fernandes) para ser elaborada e implementada.

\footnotetext{
${ }^{309}$ O Guarany é um dobrado de execução muito popular entre as bandas militares brasileiras, cuja data de composição é incerta, porém estimada no último quartel do século XIX. Sua autoria ainda é desconhecida e seu título se deve ao tema da Abertura da Ópera de Carlos Gomes, que, desenvolvido em um compasso binário em forma de dobrado, é trabalhado mediante diversas variações que percorrem a exposição, o desenvolvimento, o trio, sua reexposição e coda.

${ }^{310}$ FIGAROTE. Música no Jardim do Largo do Palácio. O Correio Paulistano, São Paulo, p. 2, 11 mar. 1890. Palcos e salões, p. 2.
} 
Para termos noção melhor dessas mudanças, em novembro de 1895, Antão lançava a ideia de realizar uma apresentação no Jardim do Palácio, como parte das comemorações aos seis anos da República, em 15 de novembro, apresentação durante a qual o ponto principal seria a reunião das bandas existentes nos Corpos Militares de então para que, sob uma única regência, pudessem executar as mesmas obras. Para o concerto, foi erguido um coreto de 50 metros de comprimento por seis de largura, a fim de acomodar os músicos que Antão conseguiu congregar, conforme suas memórias e a grande imprensa. Ainda como reflexo de seu trabalho, foi promovido ao posto de alferes na noite que antecedeu a apresentação, transformando-se no primeiro músico a atingir o oficialato na corporação, o que imprimiu um caráter de respeito à profissão e ofício não apenas na Força, mas também no mercado de trabalho musical vigente à época. Sobre esse evento, O Estado de São Paulo de 16 de novembro de 1895 relata que cerca de 6.000 pessoas aglomeraram-se no Jardim do Palácio para assistir ao concerto da Banda de Música da Força Policial, destacando que, regido pelo alferes Joaquim Antão, o conjunto foi composto de 208 músicos reunidos das diversas Bandas existentes (Corpo de Bombeiros, Regimento de Cavalaria, $1^{\circ}, 2^{\circ} 4^{\circ}$ e $5^{\circ}$ Batalhões) e de outras seções da instituição, e a execução desse programa de concerto durou cerca de duas horas e contou com o seguinte repertório:

Primeira parte: Hino Nacional, Hino da Proclamação da República, Africana, Marcha Triunfal, Cavalaria Rusticana, Tannhäuser (marcha).

Intervalo de meia hora.

Segunda Parte: Marselhesa, Sinfonia do Guarany, Aida (2 ${ }^{\circ}$ ato), Os Hugenotes (Coro da conjuração e benção dos Punkes), Hino à República e Hino Nacional. ${ }^{311}$

Nesse concerto, o que foi executado reflete certa tendência que se verificaria durante quase todo o primeiro período republicano: a utilização de transcrições de obras eruditas para bandas de música, conforme apontado no Anexo I (Tabela 8) deste estudo, que remete aos programas de concertos da Banda da Força Pública no ano de 1903. A crítica de Figarote, redigida lá pelos idos de 1890, sobre o que a Banda tocava já não fazia mais sentido em 1903. Naquele ano, o repertório já estava consolidado em obras de cunho erudito e, em especial,

${ }^{311}$ Quinze de novembro. O Estado de São Paulo, São Paulo, p. 1, 16 nov. 1895. 
famosos trechos de ópera, os quais, adaptados e instrumentados para conjuntos de sopros, formavam aos poucos o gosto de plateias nos jardins e passeios públicos, plateias essas que, à exceção dos imigrantes, pouco tinham ouvido esse tipo de música antes.

Confirmando essa tendência, os dados da Tabela 8 trazem o que foi apresentado no ano de 1903, como resultado da análise de 78 programas de concerto encontrados em publicações de $O$ Estado de São Paulo e O Correio Paulistano. Como demonstrado no capítulo 1, prevaleceram as obras de compositores estrangeiros - sobretudo dos italianos, com $26 \%$ das obras executadas -, o que ratifica a influência da imigração na música da cidade. Os gráficos também apontam para situações que devemos recordar: Verdi foi o compositor mais tocado (na soma de todas as suas obras em comparação a outros compositores); La Gioconda (finale $4^{\circ}$ ato), de autoria de Ponchielli, foi a obra mais executada naquele ano, com 17 execuções; e o gênero mais tocado foi a ópera, o que confirma que a transição de repertório dentro da Banda de Música da Força Policial haviam se consolidado na passagem do século XIX para XX. Este resultado, provavelmente foi possibilitado pela viagem de Antão para a Itália nos anos de 1898 e 1899. A Banda da Força, portanto, não tocava mais o que fora criticado por Levy na década final dos oitocentos. Mudara tal qual as outras bandas, colorindo a cidade de "boa música", adormecendo, dessa forma, os cateretês, maxixes, tangos e polcas. Estes, no entanto, reapareceriam cerca de dez anos depois, não nos concertos, mas sim nos discos, como veremos mais adiante.

Se, para alguns, já era de bom tamanho ouvir Wagner, Puccini, Ponchielli e os demais compositores, para outros, a Banda poderia tocar mais e melhor. Em artigo publicado em $O$ Estado de São Paulo em $1^{\circ}$ de maio do mesmo ano de 1903, um crítico anônimo arguia a banda sobre a repetição de um repertório já exaustivamente apresentado. Questionava se a renovação das obras não estaria se dando em razão da falta de ensaios, má vontade dos executantes ou da saída de um ou outro músico. Apontava ainda que o concerto que ouvira na noite anterior (30 de abril de 1903), teria apresentado “...um Ruy Blas medíocre; uma Cavalaria Rusticana sem colorido e uma Aída desastrada...".312 Defendia que, entre Wagner e a "frivolidade" das óperas italianas transcritas, havia uma lacuna a ser preenchida por bom gosto. Alegava que entender Wagner, portanto, não era para qualquer um e, dessa feita, também quem o entendia já estava cansado de ouvir Puccini. Exigente, queria algo diferente

\footnotetext{
${ }^{312}$ Artes e artistas. O Estado de São Paulo. São Paulo, p. 2, 1 mai. 1903.
} 
e de qualidade. Terminava sua crítica de forma otimista, crendo que a competência e a educação musical do maestro Antão dariam conta de alterar a organização dos programas de concerto, indicando para isso recorrer aos compositores românticos ou à escola francesa. Nesse sentido, pelo que os programas de 1915 e 1925-30 demonstram, Antão leu e, provavelmente influenciado pela Missão Francesa, que chegaria em menos três anos, acatou a crítica, dando uma nova guinada no repertório a partir da segunda década do século XX. ${ }^{313}$ Vale lembrar ainda que essa transição de repertório não ficou restrita à Banda da Força Pública: estendeu-se a todas as corporações musicais existentes àquele momento.

Como pode ser constatado nos programas de concerto publicados na grande imprensa, bem como nos anexos que contêm parte da discografia passível de levantamento dessas bandas civis, havia descompassos entre o que fora gravado em disco e o que era apresentado nos programas de concerto das bandas. Quando Figarote fez a crítica ao repertório em 1890, a Banda tocava segundo eles "maxixes pornográficos". A partir da última década do século XIX, o repertório mudou. No entanto, a indústria fonográfica, como veremos adiante, de certo modo, forçou o retorno do repertório das bandas a algo mais popular, exigindo que elas gravassem novamente músicas curtas, como os maxixes e cateretês.

\section{Allegro: a importância da Missão Francesa}

A chegada da primeira Missão Militar Francesa em 1906 foi central para a consolidação da Força Pública de São Paulo e serviu também para a evidente evolução de sua Banda de Música. Ela ganhou gradativamente mais espaço fora do quartel, aumentou em número de figuras, foi objeto de uma legislação específica e entrou na ciranda fonográfica.

A Força Pública que chegou à gestão de Jorge Tibiriçáa ${ }^{314}$ deveria fazer frente à representação de grandeza econômico-política e ideológica que São Paulo passava a impor ao país naquele momento. Um de seus objetivos era reforçar o poder estadual em relação aos mandonismos municipais pelo estado afora, fruto do coronelismo. Na visão de Joseph Love:

\footnotetext{
${ }^{313}$ Nos programas de 1915 e 1925-30, a grande "aparição" foi o compositor francês Emile Waldteufel que, roubando a cena, seria responsável por grande parte das obras executadas pela banda da Força a partir dos anos 1910 .

314 Jorge Tibiriçá Piratininga governou o estado de São Paulo durante os períodos de 18 out. 1890 a 07 mar. 1891 e em um segundo mandato, foi seu presidente entre 01 mai. 1904 a 01 mai. 1908 eleito pelo Partido Republicano Paulista. No momento da contratação da missão, o Secretário de Justiça e Segurança Pública (pasta à qual a Força Pública era subordinada) era Washington Luís.
} 
A nível estadual, a Força Pública paulista contribuiu para a crescente integração organizacional ao reforçar a concentração de autoridade nas mãos do governador. A reforma do sistema judiciário estadual, juntamente com a militarização da Força em 1906, enfraqueceram o poder dos coronéis, impedindo, assim, a emergência de senhores locais todopoderosos, verdadeiros "senhores da guerra" $[\ldots]]^{315}$

Apesar dessa representação bélica que o estado pensava possuir, faltava ainda muito para se alcançar o resultado pretendido e, nesse sentido, o campo militar profissional era o que mais padecia. Havia necessidade de transformar uma corporação semiamadora em outra profissional e atualizada, conforme a tecnologia armamentista da época. Para a solução dessa questão, em 22 de dezembro de 1905, foi assinado um acordo em Paris entre o governo brasileiro e o Ministro da Guerra francês, General Eugène Etienne, ${ }^{316}$ acordo esse no qual a França ${ }^{317}$ se comprometia a enviar uma missão de instrução militar para a Força Pública do Estado de São Paulo, em princípio por dois anos. ${ }^{318}$ Essa foi a primeira missão estrangeira desse porte a chegar ao Brasil. ${ }^{319}$ Chefiada pelo coronel Paul Balagny auxiliado pelo tenente Raul Negrel e sargento André Hoenix de La Brousse, ${ }^{320}$ a equipe aportou em São Paulo em março de 1906, instalando-se no $1^{\circ}$ Batalhão de Infantaria. Os franceses trouxeram novas técnicas de combate e instrução que, somadas ao remodelamento dos armamentos comprados a partir de então, forjaram um caráter mais militarista à instituição. Junto a esse caráter, a presença e a participação da Banda de Música em todas as atividades desenvolvidas pela Força tornaram-se cada vez mais evidentes. Segundo a tradição militar, trazida pelos franceses, bandas são partes integrantes dos exércitos. São a alma dos regimentos quando

\footnotetext{
${ }^{315}$ LOVE, Joseph. A Locomotiva: São Paulo na Federação Brasileira. 1889-1937. Rio de Janeiro: Paz e Terra, 1982. p. 304.

${ }^{316}$ Ministre de La Défense (Ministro da Guerra) francês no período de 12 nov. 1905 a 25 out. 1906 e de 21 jan. 1913 a 09 dez. 1913.

317 O Ministro das Relações Exteriores do Brasil naquele momento era o Barão do Rio Branco, que se posicionou contra a contratação de uma Missão Francesa, sendo a favor, no entanto, de uma missão germânica. Pode ser que o fato de ter nascido em Paris e ser filho de mãe francesa tenham pesado na decisão de Jorge Tibiriçá em pender para os franceses.

${ }^{318}$ Tais contratos foram sucessivamente renovados, e a missão permaneceu em São Paulo entre os anos de 1906 a 1914, quando se retirou em razão da Primeira Guerra Mundial, retornando em 1919 para somente em 1924 deixar o estado definitivamente.

${ }^{319}$ MORAES, Waldyr Rodrigues de. Em busca do passado. A Força Policial, São Paulo, n. 23, p. 75, jul.-ago.set. 1999.

${ }^{320}$ O coronel Paul Balagny e o sargento André Hoenix de La Brousse eram oriundos do $103^{\circ}$ Regimento de Infantaria do exército francês. Já o tenente Raul Negrel era do $24^{\circ}$ Regimento de Infantaria. Durante a missão, Balagny foi comissionado no posto de coronel da Força Pública, recebendo vencimentos iguais aos de Cmt. Geral. Negrel foi comissionado no posto de tenente-coronel e La Brousse no de alferes.
} 
respeitadas e valorizadas; são instrumentos de motivação interna e desenvolvimento de vínculos afetivos. Desse modo, iniciava-se uma fase de desenvolvimento e valorização da Banda de Música dentro da Força Pública, graças a essa nova mentalidade chegada da Europa.

Em 15 de novembro daquele ano, ${ }^{321}$ cerca de 10.000 pessoas presenciaram o início de uma tradição que se inventava na cidade: a comemoração, pela Forca Pública do Estado, do aniversário da República nos Prados da Mooca. Naquele dia, após uma alvorada festiva no Quartel da Luz às 7h30, um toque de clarim colocou em marcha 600 homens pertencentes ao $1^{\circ}$ Batalhão, divididos em quatro companhias com destino ao local da apresentação. Saindo pela avenida Tiradentes, seguiram pelas ruas São Caetano, Monsenhor Andrade e Bresser. O Corpo de Cavalaria já seguia pela rua São Caetano: eram mais 200 homens e cavalos. Ainda na rua São Caetano, juntaram-se ao efetivo o Corpo de Bombeiros com 140 homens e uma coluna dos $3^{\circ}$ e $4^{\circ}$ Batalhões da Guarda Cívica. À frente, puxando o efetivo, a Banda da Força Pública, regida pelo inspetor tenente Joaquim Antão, com cerca de 100 homens somados às várias bandas de tambores e cornetas das outras unidades da Força Pública, que juntas proporcionavam um espetáculo à parte. Conforme a grande imprensa, pela primeira vez no Brasil, uma Banda daquelas dimensões se fazia presente em uma parada militar daquela magnitude. Às 9h, tocando Défile, acompanhado dos tambores e cornetas, o efetivo entrou no campo de desfile, trazendo um contingente de mais de 1.200 soldados para a celebração. Após as devidas apresentações, a Banda executava Le Regiment de Sambre et Meuse para a acomodação do efetivo nas devidas posições, preparando-o para as continências e honras militares a serem prestadas ao Presidente do Estado. Continências feitas com o devido exórdio, marcha batida executada, o Presidente foi convidado a passar em revista as tropas ao som da Marselhesa, culminando a revista com a autorização para o desfile. O espetáculo desenrolou-se com apresentações da infantaria, cavalaria e bombeiros, demonstrando os ganhos técnicos de manejo de armamentos e munições adquiridos desde a chegada da Missão Francesa. Após o término e a dispensa das tropas, a Banda novamente executava Sambre et Meuse, partindo da Mooca, seguindo pelas ruas Bresser, avenida Rangel

\footnotetext{
321 1906: $17^{\circ}$ aniversário da República e o primeiro a ser comemorado segundo os ensinamentos da Missão Militar Francesa nos Prados da Mooca (também chamado de Hipódromo da Mooca). Conforme apontado no capítulo 1, esses eventos comemorativos se desenvolveram de 1906 a 1927, sempre em 15 de novembro e no mesmo local.
} 
Pestana, Ladeira do Carmo, Largo do Palácio, ruas do Thesouro, Quinze de Novembro, praça Antônio Prado, ruas de São Bento, Florêncio de Abreu e Largo do Jardim. No Largo de São Bento, o Corpo de Bombeiros e as seções de inferiores da Guarda Cívica desmembraram-se da tropa. A Banda de Música, conduzindo o restante do efetivo, seguiu rumo à avenida Tiradentes para se internar no $1^{\circ}$ Batalhão, apreciar a comida melhorada do rancho e saudar os milicianos agraciados com o indulto de suas penas naquele dia especial. Daquele local, saiu apenas no início da noite, dirigindo-se ao Jardim do Palácio, para poder ocupar a concha acústica e promover o concerto que encerraria as comemorações, conforme o seguinte programa:

Primeira Parte: Leopoldo Miguez - Hino da Proclamação da República; Francisco Manuel da Silva - Hino Nacional Brasileiro; Rouget - A Marselhesa.

Segunda Parte: Puccini - Tosca (3 Ato); Francisco Braga - Hino Marcha Solene; Mascagni - Iris, Hino ao Sol.

Terceira Parte: Spinelli - A Dasse Porto; Puccini - La Boheme; e Alexandre Levy Samba, suíte bresilliènne. ${ }^{322}$

É importante salientar que, a partir da chegada dos franceses, a Banda tornou-se definitivamente parte indissolúvel do corpo de tropa para os treinamentos em todas as solenidades e eventos nos quais a Força passou a tomar parte a partir de 1906. É fato também que essa missão militar traria, como consequência para a Banda de Música, o aumento e o incremento de seu repertório, o qual até aquele momento tinha estado apoiado nos autores italianos. A ordem a partir de então, foi trazer para o repertório Waldteufel e suas valsas, além de marchas, como Sambre et Meuse para os desfiles, executada como piloto já na primeira demonstração em 15 de novembro de 1906. Outro ponto importante a se observar foi que a Banda sai do quartel e aproxima-se da população conforme as diretrizes da Missão. A tradição das bandas de música dos regimentos europeus, que se tornaram parte do ambiente urbano nas grandes cidades como Paris, Londres, Viena e Berlim, consolidou-se a partir

${ }^{322}$ Quinze de novembro. O Estado de São Paulo, São Paulo, 15 nov. 1906. 
desse momento na Força Pública. Buscando maior proximidade junto à população e angariando de certa forma mais simpatia, a Banda tornou-se, pelas ideias do chefe da Missão, um verdadeiro instrumento de relações públicas da Força Pública, passando a agir tanto em conjunto à tropa - quando em exercícios ou apresentações combinadas, como foi o caso destacado anteriormente - como em apresentações solo nos parques e jardins da cidade. Como resultado dessa política implantada a partir da chegada dos franceses, os números de prestação de serviços de 1906 subiram significativamente em relação aos anos anteriores. Esses números, de certa forma, indicam que a opção de a Banda sair do quartel e se aproximar da população poderia ser considerada um caminho definitivo. A Banda precisava ser mais vista e, portanto, mais exposta; agradar ao público, tocando um repertório condizente com esse objetivo e ser mais presente nos espaços estratégicos da cidade para cativar a plateia, fosse esta a elite política ou o operariado paulistano.

Os resultados dessa nova visão corporativa implantada pela Missão no âmbito da Banda de Música, como comentado acima, começaram a se evidenciar no levantamento de 167 eventos em que a Banda esteve presente na cidade de São Paulo em 1906. Ao final daquele ano, os dados revelam a alta produtividade da Banda, assim como a diversidade de naturezas de prestações de serviços, o que ratifica a sensação de que a Banda transitava pelos mais diversos lugares sociais da cidade; no entanto, os de maior frequência foram os Jardins da Luz e do Palácio. A Banda promoveu 86 apresentações no Jardim da Luz, 51 no Jardim do Palácio, realizou dez serviços internos à Força Pública (solenidades dentro do quartel), tocou em seis datas comemorativas de forma externa (junto à comunidade), participou de quatro eventos envolvendo escolas superiores (faculdades de farmácia, engenharia, direito, etc.), esteve três vezes no Congresso do Estado para sessões solenes, e tocou duas vezes para associações ou campanhas beneficentes, festas religiosas e escolas, além de haver se apresentado uma vez no Parque Antarctica. ${ }^{323}$ Outro ponto que merece observação foi o deslocamento para o local mais distante para atendimento de serviços musicais - o Parque

\footnotetext{
${ }^{323}$ É preciso lembrar que, nesse momento, havia duas bandas (seções) na Força Pública e que, portanto, os números resultantes das apresentações do levantamento foram o total de todas as prestações de serviços por essas duas bandas de música; por vezes em conjunto, por vezes separadas.
} 
Antarctica (zona oeste da cidade) -, o que revela também que o triângulo central ainda mantinha uma certa hegemonia das atrações culturais. ${ }^{324}$

Contando com um efetivo de 5.029 homens, ${ }^{325}$ em 22 de abril de 1908, a Força teve a oportunidade de se exibir ao então Ministro da Guerra, Marechal Hermes da Fonseca, apresentando seus exercícios de guerra. A Banda de Música, somada ao $1^{\text {o }}$ Batalhão de Infantaria, apresentou exercícios de desenvolvimento com e sem arma, esgrima de baioneta, escola de companhia, manejo de armas, escola de batalhão, além das evoluções de conjunto e assalto. À cavalaria, coube fazer exercícios de escola de esquadrão, combate e outras demonstrações e, em manobra final, uma simulação de tomada do leito da estrada de ferro Cantareira, feito com um assalto à baioneta, pelo $1^{\mathrm{o}}$ Batalhão. ${ }^{326}$ Essa demonstração produziria excelentes efeitos, gerando o reconhecimento profissional do Exército brasileiro por muitos anos, incluído todo o período do mandato de Hermes da Fonseca como Presidente da República (1910-1914).

Entre 11 de agosto e 15 de novembro de 1908, ocorreu a Exposição Nacional Comemorativa do $1^{\circ}$ Centenário da Abertura dos Portos do Brasil às nações amigas, promovida pelo governo federal no bairro da Urca (Praia Vermelha), na cidade do Rio de Janeiro. Cada estado foi convidado a levar amostras de sua cultura para a exposição e um dos grupos que seguiu para o Rio foi a Banda da Força Pública. Regida por Antão, realizou vários concertos com repertório variado, incluindo obras de Bach, Beethoven, Wagner, além dos brasileiros Alberto Nepomuceno, Henrique Oswald, Leopoldo Miguez e Carlos Gomes. Participou também de um concurso organizado, venceu-o e, como prêmio, recebeu uma batuta de marfim ${ }^{327}$ com inscrição, entregue pelo jornalista Alcindo Guanabara. ${ }^{328}$

À semelhança desse concurso realizado no Rio de Janeiro, os concursos entre bandas de música eram práticas muito comuns à época também em São Paulo. A participação da Banda de Música da Força Pública nesses certames era parte também da estratégia implementada a partir de 1906 para um contato mais próximo entre a população que os

\footnotetext{
${ }^{324}$ As fontes utilizadas para esse levantamento foram as edições de $O$ Estado de São Paulo entre 1 de janeiro e 31 de dezembro de 1906.

${ }^{325}$ Lei n. 1092-A de 16 out. 1907. Fixa a Força Pública do Estado, para o exercício de 1908. ALESP, São Paulo, 1907.

${ }^{326}$ DALLARI, Dalmo de Abreu. O pequeno exército paulista. São Paulo: Perspectiva, 1977. p. 45.

${ }^{327}$ Essa batuta faz parte ainda hoje do acervo histórico do Corpo Musical da Polícia Militar do Estado de São Paulo.

${ }^{328}$ FERNANDES, Joaquim Antão. Minha autobiografia. São Paulo, s/editor, 1943. p. 15. Mimeografado.
} 
frequentava e a instituição por meio de sua Banda. Em 1909, foi realizado um dos concursos, que envolveu várias corporações na cidade de São Paulo e do qual puderam participar bandas do estado todo. Os organizadores, conforme as memórias de Joaquim Antão, foram ele e José D’Aló, proprietário da fábrica de instrumentos musicais do mesmo nome. O objetivo do concurso era arrecadar fundos para a edificação de uma estátua em homenagem a Carlos Gomes. Realizado no Jardim da Luz, teve como bandas vencedoras: Humanitária de Santos, Liberdade de São Roque e Saltense de Salto de Itu. O corpo de jurados foi composto por nomes expressivos da música paulistana, como, por exemplo, os maestros João Gomes, Francisco Braga, Chiaffarelli e Henrique Oswald. Na mesma ocasião, Antão apresentou um trabalho de sua autoria ${ }^{329}$ para conhecimento dos maestros jurados. Tratou-se de uma instrumentação do Hino Nacional Brasileiro com cornetas e tambores em marcha, que acabou redundando na inclusão da Marcha Batida ao Hino Nacional em $\mathrm{B} b$, quando de sua execução para continência. ${ }^{330}$

Em 29 de outubro de 1909, uma nova lei de reorganização da Força Pública foi votada e aprovada. ${ }^{331}$ Pelo novo dispositivo, o efetivo era aumentado para 5.044 homens, e também nesse momento criavam-se duas vagas de alferes para a Banda de Música, mantendo-se as quatro vagas de músicos de classe distinta, 12 músicos de primeira classe, 20 de segunda e 24 de terceira, o que aumentava agora o número total para 63 componentes sediados no $1^{\circ}$ Batalhão de Infantaria. Ainda no mesmo ano, a Banda promoveu concertos nas cidades de Santos, Campinas, Ribeirão Preto, Piracicaba, Vila Americana, Taubaté, Pindamonhangaba e outras do interior do estado. O eficiente sistema de comunicações pela via férrea aos poucos encurtava as distâncias, permitindo que essas atividades, antes difíceis e onerosas, se tornassem cada vez mais próximas e presentes no interior.

Como a demanda por cultura e diversões públicas aumentou de forma considerável, no mesmo ritmo do desenvolvimento da cidade, o Governo do Estado fez publicar o Decreto n. 1.714, que regulamentava os divertimentos públicos, no qual se inseriam as bandas de

\footnotetext{
${ }^{329}$ Fruto de experimentações no campo da instrumentação para banda, a proposta floresceu devido ao fácil acesso que Antão possuía a esse tipo de grupo, quando, unindo todas as Seções da Banda de Música, banda de tambores, cornetas e clarins, passava a possuir seu laboratório instrumental necessário às suas pesquisas e futura proposta.

${ }^{330}$ Lei $\mathrm{n}^{\circ} 5.700$ de $01^{\circ}$ set. 1971 . Dispõe sobre a forma e apresentação dos símbolos nacionais e dá outras providências. Art. $6^{\circ}$ e $\S$ único c/c Art. 25 I. Brasília, 1971.

${ }^{331}$ Lei n. 1175 de 29 out. 1909. Fixa a Força Pública para o exercício de 1910. ALESP, São Paulo, 1909.
} 
música e conjuntos musicais de todos os tipos. Tal fiscalização competiu à Secretaria de Justiça e Segurança Pública (a mesma pasta à qual era subordinada a Força Pública). O Estado regrava, dessa forma, as concessões e licenças para funcionamento dos divertimentos, bem como baixava normas de regulamentação, como medidas de segurança, higiene e comodidade, preocupando-se com a iluminação, espaço e demais necessidades. Indo além, o Estado estabelecia ainda normas de ação quanto aos deveres dos empresários, diretores, artistas e empregados de companhias, expectadores, e claro, da polícia.

Para termos uma ideia da rigidez imposta pelo regulamento, seu Art. 41 previa que:

Artigo 41. - Os artistas, inclusive os professores de orchestra ou banda de musica, são obrigados a desempenhar o serviço para que se houverem contractado, verbalmente ou por escripto, salvo o caso de molestia, provado com attestado medico, motivo de força maior plenamente justificado ou falta de pagamento dos seus vencimentos. ${ }^{332}$

O referido Decreto, ainda enquadrava o serviço dos bombeiros e as medidas preventivas de incêndio a serem adotadas nas casas de espetáculo ou diversões instaladas de forma provisória, como parques em locais abertos. Abordando também os cinematógrafos, trazia, ao final, uma parte na qual estipulava multas pelas infrações previstas naquele regulamento, no caso de inobservância por parte dos empresários. Dessa forma, o Estado disciplinava as prestações de serviços e seus prestadores, impondo a estes um conjunto de medidas que, anteriormente praticados de forma verbal, passavam a ser registrados em contratos sob a égide desse código, na tentativa de manter-se um certo controle nas diversões dos cidadãos.

Passada a primeira década do século XX, a Banda havia se fortalecido como ente cultural ativo dentro da sonoridade da cidade, porque não mais se restringia a prestar seus serviços à Força Pública (nos desfiles, exibições e exercícios militares); ao contrário, tinha se aproximado muito da população, sobretudo após a Missão Francesa. Seguindo os preceitos impostos pelas novas estratégias da Força Pública de relacionamento com o público externo aos quartéis e sentindo-se valorizada pela instituição em razão do ganho desses espaços, tanto interna como externamente, a Banda prosseguiu para a segunda década, incorporando uma nova tecnologia que, chegada ao Brasil no início dos 1900 no Rio de Janeiro, proporcionou

\footnotetext{
332 Decreto n. 1.714 de 18 mar. 1909. Dá regulamento para os divertimentos públicos nos termos do artigo 28 da lei $n^{\circ}$ 1.103, de 26 de novembro de 1907 e mais disposições em vigor. ALESP, São Paulo, 1909.
} 
seu registro sonoro e a possibilidade de que tais registros chegassem até nossos dias, conforme o encarte anexo. A partir dessa segunda década, a Banda passou a dividir seu tempo entre os ensaios, viagens, apresentações e o novo e privado espaço: o estúdio.

\section{Afretando: divulgação e fonografia}

A década de 1910 foi importante para a Banda de Música da Força Pública, uma vez que ela saiu do ambiente paulistano e passou a viajar por cidades do interior do estado e também à Capital Federal. Se durante a primeira década do século XX a Banda se fez conhecida na cidade de São Paulo, a partir de 1910 ela passaria a ser conhecida no estado, aumentado sua fama.

\subsection{Sobre trilhos: melhores transportes, mais viagens}

Com um sistema de comunicações sedimentado entre a capital e o interior do estado, a banda iniciou um ciclo de viagens a fim de realizar concertos. O conjunto que viajou a partir daquele ano era composto por banda completa acompanhada de tambores e cornetas, perfazendo, conforme as memórias de Antão, ${ }^{333}$ um total de 120 figuras que, em conjunto, conseguiam realizar um espetáculo raro nessas cidades interioranas. ${ }^{334} \mathrm{Em}$ várias delas, a euforia em receber a Banda era tamanha que, muitas vezes, seus maestros e músicos eram homenageados, como foi o caso de um concerto realizado em 1912 em Batatais.

No âmbito da caserna, a edição do Decreto n. $2.228^{335}$ regulamentava, a partir de então de forma mais organizada, o cerimonial militar, incluindo, é claro, nesse universo a Banda de Música. Honras à bandeira, execuções do Hino Nacional, Hino à Bandeira e proclamação da República, visitas aos quartéis, honras fúnebres e toda sorte de ritos próprios da vida militar passaram a ser regrados a partir de 1912, conforme a ótica desse novo regulamento publicado em abril daquele ano. Como membro de um corpo, a Banda reafirmou-se como parte indispensável desse todo e passou a ser tão imprescindível para o

\footnotetext{
${ }^{333}$ FERNANDES, Joaquim Antão. Minha autobiografia. São Paulo: s/editora, 1943. p. 15. Mimeografado.

${ }^{334}$ Foram registrados, nas edições de 1912 de O Estado de São Paulo, concertos nas cidades de Araraquara, Campinas, Batatais, Faxina (atual Itapeva), Santos e outras.

${ }^{335}$ Decreto n. 2.228 de 17 abr. 1912. Manda observar a tabella de continências da Força Pública. ALESP, São Paulo, 1912.
} 
cerimonial que, sem sua presença, as festas e os ritos não teriam a necessária sonorização, o que desqualificava, portanto, sua estética.

A festa mais comemorada ainda era o Quinze de Novembro. Em 1912, à semelhança de 1906, o Quinze de Novembro começou às 8h, quando o Presidente do Estado passou em revista as tropas da Força Pública, contando o evento, segundo O Estado de São Paulo, com 2.000 soldados. ${ }^{336}$ Esgotados os convites oficiais em 14 de novembro, o público que quisesse participar do acontecimento poderia fazê-lo, desde que se acomodasse (em pé) ao lado dos palanques montados para receber os convidados.

$\mathrm{O}$ rito do feriado seguiu as mesmas manifestações de sempre. Após a alvorada, os Corpos seguiram para a Mooca e, após o desfile, retornaram ao Quartel da Luz, saindo às 7h30 da noite para uma Marche aux flambeaux com destino ao Largo do Palácio. De lá, a marcha seguiu para o Largo do Jardim, rua Florêncio de Abreu, Largo de São Bento, rua de São Bento, rua Direita, Largo da Sé, rua Floriano Peixoto e Largo do Palácio, onde prestou a devida continência ao Presidente do Estado. O regresso foi pelas ruas Anchieta, 15 de Novembro, praça Antônio Prado, do Rosário, Boa Vista, Largo de São Bento, Líbero Badaró, do Seminário, Brigadeiro Tobias e Largo do Jardim e, finalmente, o Quartel da Luz. Para encerrar as comemorações, às $8 \mathrm{~h} 30$ da noite, houve um grande concerto com a participação do Presidente do Estado, seus secretários de governo e membros do corpo consular na cidade no mais novo e nobre espaço da cidade - o Teatro Municipal -, inaugurado no ano anterior. Uma orquestra regida pelos maestros Giulio Bastiani e João Gomes d'Araújo, executou obras de Mendelssohn e do próprio João Gomes d'Araújo, incluindo solos de Maria Petrowna. Para a abertura do concerto: Hino Nacional Brasileiro e Hino do Proclamação da República. A orquestra foi acompanhada pelo coro dos alunos do Conservatório Dramático Musical de São Paulo, marcando presença nesse novo espaço da elite cultural paulistana, cujo saguão, restaurante ou esplanada eram os únicos locais em que as bandas podiam tocar.

De volta à Força Pública, foi editada, em dezembro de 1912, a Lei n. $1.343,{ }^{337}$ que gerava outro ganho político e profissional para o conjunto musical, ao criar uma vaga de capitão inspetor, uma vaga de tenente subinspetor e manter uma vaga de alferes auxiliar de música. ${ }^{338}$ Isso produzia, de fato e de direito, uma expectativa de carreira para o músico que

\footnotetext{
${ }^{336}$ Quinze de novembro. O Estado de São Paulo, São Paulo, 15 nov. 1912. Notícias Diversas, p. 6.

${ }^{337}$ Lei no 1.343 de 17 dez. 1912. Fixa a Força Pública para o exercício de 1913. ALESP. São Paulo: 1913.

${ }^{338}$ O capitão foi Joaquim Antão Fernandes, o tenente Benedicto de Assis Lorena e o alferes Salvador Chiarelli.
} 
pretendesse exercer as funções e o posto de inspetor (agora no cargo de capitão), valorizando profissionalmente esses músicos, equiparando-os às carreiras das demais especialidades já existentes no Corpo, como médicos, veterinários e engenheiros, por exemplo. Outro ponto importante foi também a sedimentação da carreira de praça por meio de uma distribuição mais equânime de vagas. Sem alterar o número do efetivo, a Banda permaneceu a mesma, porém as classificações de seus integrantes passaram a ser iguais em relação à tropa: quatro $1^{\circ}$ sargentos músicos de classe distinta (remuneração de $1^{\circ}$ sargento); $122^{\circ}$ sargentos músicos de primeira classe (remuneração de $2^{\circ}$ sargento); 20 soldados músicos de segunda classe (remuneração de furriel $^{339}$ ) e 24 soldados músicos de terceira classe (remuneração de cabo de esquadra). Dessa forma, o vencimento dos músicos de menor graduação da Banda passou a ser equivalente ao de cabo, ou seja, passou a ser superior ao vencimento do soldado de outras armas, o que facilitou, assim, a contratação de profissionais para os quadros da Banda. Vale lembrar que essa legislação seguiria sem maiores alterações até o ano de 1917. 340

Em 1915, os locais de apresentação da Banda, continuavam a ser os pátios dos Batalhões de Infantaria e as comemorações em solenidades militares da própria Força, o Jardim da Luz, o Jardim do Palácio, e o Anhangabaú (ou Esplanada do Teatro Municipal). Os atendimentos às solicitações públicas da prefeitura, às prefeituras do interior do estado, festas e feriados nacionais, estaduais e municipais, inaugurações, escolas e faculdades também seguiram em um ritmo de gradativo crescimento. Todas essas participações - reflexo político da Missão Francesa - atingiram seu objetivo de cativar o público e aproximá-lo dos quartéis. Curiosamente, as solicitações da Igreja para participação em festas religiosas desapareceram do rol de clientes da Banda.

Em levantamento realizado, tendo como fonte as edições de $O$ Estado de São Paulo, no período de $1^{\circ}$ de janeiro a 31 de dezembro de $1915,{ }^{341}$ foi possível aferir que a Banda

\footnotetext{
${ }^{339}$ A Ordem do Dia n. 4 de 4 jan. 1918, em obediência à Lei n. 1.558 de 20 out. 1917, alterou a denominação dos postos de tenente para $1^{\circ}$ tenente, alferes para $2^{\circ}$ tenente, furriel para $3^{\circ}$ sargento e cabo de esquadra para cabo.

${ }^{340}$ Entre o período que vai de dezembro de 1912 a outubro de 1917, foram publicadas as seguintes leis estaduais que alteraram a Força Pública, sem, contudo, alterar a Banda de Música: Lei n. 1395-A de 17 dez. 1913 , Lei n. 1.444-A de 24 dez. 1914, Lei n. 1.454 de 29 dez. 1914, Lei n. 1.483-A de 7 dez. 1915, Lei n. 1.498 de 30 dez. 1915, Lei n. 1.511-A de 2 dez.1916, e Lei n. 1.558 de 20 out. 1917. Como a fixação de efetivo e salários era pauta anual do executivo, a maior parte das alterações se deram nesse campo, aumentando ou diminuindo o efetivo da Força, mas não da Banda.

${ }^{341}$ É preciso levar em consideração que os dados levantados geraram números que podem ser maiores, uma vez que apenas uma fonte foi utilizada para a compilação dos dados, gerando a possibilidade de que muitas outras
} 
sonorizou, pelo menos, uma comemoração de feriados nacionais, uma peça de teatro, um corso carnavalesco da avenida Paulista. Também fez três viagens para o interior do estado de São Paulo, ${ }^{342}$ participou de três eventos em faculdades e escolas, três campanhas de fundo social ou de cunho solidário, cinco eventos de associações, sete solenidades abertas da Força Pública, nove solenidades envolvendo os poderes executivo, legislativo e judiciário do estado, 27 concertos na esplanada do Teatro Municipal de São Paulo, 36 concertos no Jardim da Luz e 57 concertos no Jardim do Palácio, perfazendo um total de 155 prestações de serviço registradas pelo jornal. Nesses números, não estão computadas as atividades internas da Banda na sua corporação mantenedora, como comemorações militares, treinamentos, desfiles, alvoradas e toda sorte de participações das rotinas dos quartéis. Os números demonstram um mesmo compasso em relação à análise anterior feita em 1906, corroborando o argumento de que houve uma retomada dos espaços públicos da cidade pela Banda de Música em busca de seus objetivos: a aproximação com a população e a ocupação desses espaços.

O ano de 1917 trouxe consigo a efervescência de movimentos sociais operários que culminaram em greves, sendo a principal delas deflagrada em julho daquele ano. No entanto, em 25 de janeiro (aniversário da cidade), um evento realizado pelo Movimento Escoteiro de São Paulo abriu as portas para que a Banda de Música pudesse desfrutar o mais cobiçado palco musical da cidade: o Teatro Municipal. ${ }^{343}$ Embora o dividisse com uma orquestra de professores sob a regência do maestro D’Arce, a Banda naquela noite em que "a casa ficou cheia”, não estava ao lado de fora, como de costume. Políticos, militares da Força Pública, familiares de escoteiros e dos músicos da Banda puderam apreciar um espetáculo que uniu o movimento por meio de um bailado protagonizado pelos jovens à Banda, a qual, a partir de então, passaria a frequentar aquele espaço, deixando de tocar apenas em sua esplanada. No programa, a peça $O$ Guarany foi escolhida como abertura, sendo executados também o Hino à Bandeira, Hino Nacional, a Canção de Marcha dos Escoteiros e a Suíte Bresilliènne de Alexandre Levi. Em $1^{\circ}$ de abril, novamente a Banda voltaria ao palco do Municipal, convidada para um concerto durante uma conferência do movimento escoteiro de São Paulo.

prestações de serviço tenham sido realizadas sem o devido registro pelo jornal O Estado de São Paulo no ano de 1915.

${ }^{342}$ As viagens foram para os municípios de Campinas, Vila Americana (atual Americana) e São Carlos.

${ }^{343}$ Escotismo. O Estado de São Paulo, São Paulo, p. 7, 27 jan. 1917. 
Alternando entre debates e peças, o festival ocorreu com a apresentação praticamente do mesmo programa executado em 25 de janeiro. ${ }^{344} \mathrm{O}$ convite para as participações nas solenidades dos escoteiros no Teatro Municipal certamente teve a influência do coronel Pedro Dias de Campos. Oficial da Força Pública que apadrinhou o movimento escoteiro no Estado de São Paulo via também na Banda de Música da instituição uma das ferramentas ideais para as relações públicas junto à comunidade.

Durante o período de maior complexidade para a Força Pública (junho a setembro), a Banda continuou cumprindo sua rotina de concertos, mantendo-se, ao que tudo indica, distante dos problemas do operariado, apesar de pertencer à Força. A grande imprensa trouxe notícias de concertos e apresentações nos locais de costume durante todo o mês de julho daquele ano, bem como dos meses anteriores e posteriores, demonstrando que as greves em nada afetaram sua rotina. Entre os anos de 1917 e 1921, seu efetivo e sua estrutura permaneceram os mesmos até 1922, quando o cenário começaria a mudar dentro dos quartéis.

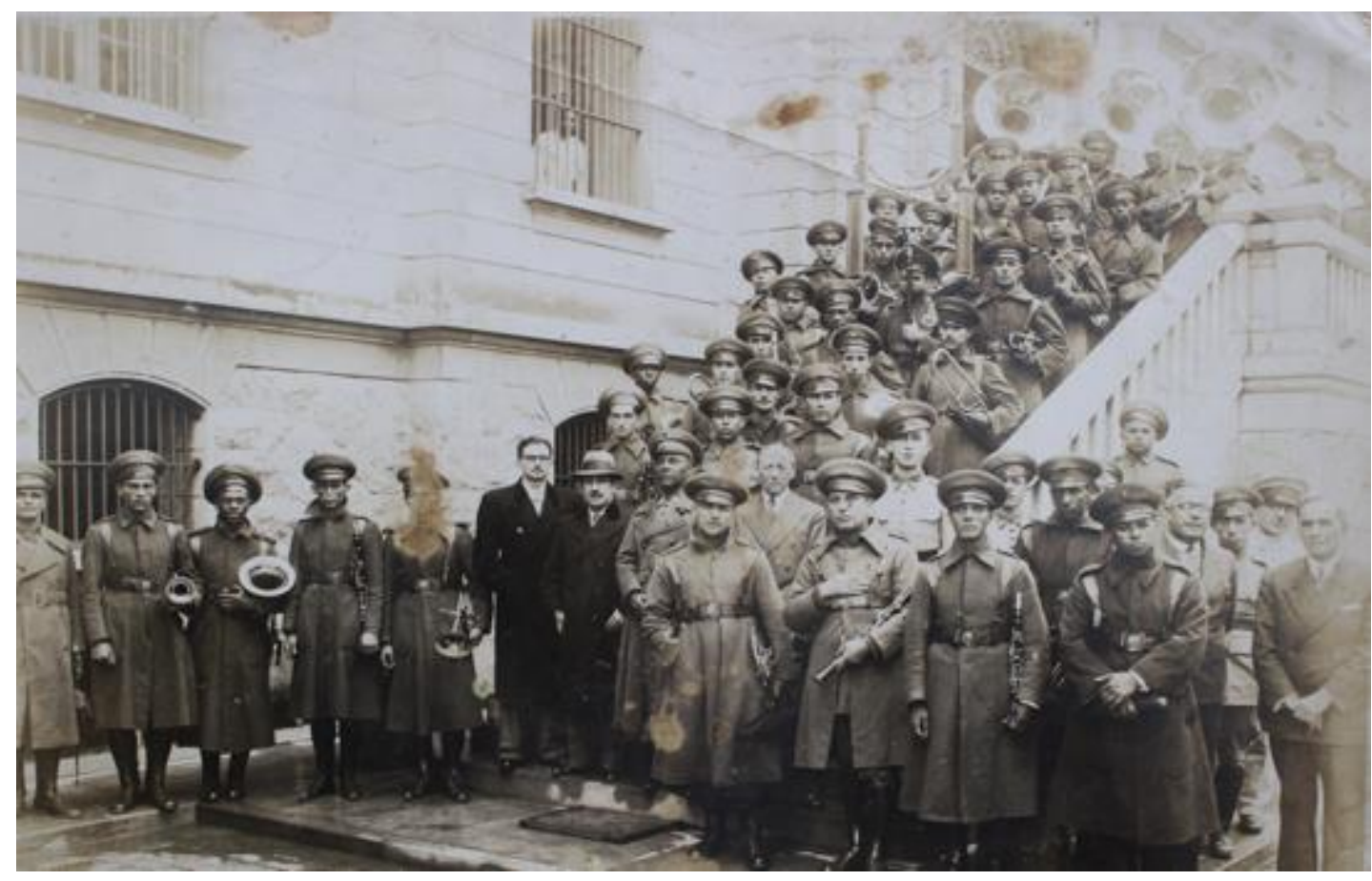

Figura 19.

Banda de Música da Força Pública do Estado de São Paulo. Data estimada pelo pesquisador 19181920

Local: Possivelmente escadaria defronte à sede do $5^{\circ}$ Batalhão de Caçadores Paulista.

\footnotetext{
344 OLAVO Bilac e os escoteiros. O Estado de São Paulo, São Paulo, p. 4, 30 mar. 1917.
} 
Fonte: Acervo fotográfico do Corpo Musical da Polícia Militar do Estado de São Paulo. Autoria desconhecida.

Na fotografia acima, cuja data de produção é estimada entre os anos de 1918 e 1920, pode-se observar uma das Seções da Banda, ${ }^{345}$ Seção essa que contava com aproximadamente 35 músicos. Pode-se perceber a forte presença do naipe dos metais e poucos músicos portando instrumentos do naipe de madeiras, além de percussionistas. Ao centro do primeiro degrau da escada, ao lado direito de um homem não identificado de chapéu branco, a figura de Joaquim Antão paira sobre o grupo que lhe cede o lugar de destaque na fotografia. Também ao centro, porém no meio da escada, é possível notar-se a presença de um soldado empunhando a árvore de sinos (estandarte da Banda de Música), símbolo tradicional das bandas militares que, aos poucos, foi desativado ao longo da segunda metade do século XX.

Em suma, ao obter meios para viajar ao interior do estado, a Banda da Força Pública divulgou o seu trabalho, o que a fortaleceu e valorizou. As apresentações musicais nos municípios do interior era uma ferramenta da qual outras bandas da capital não dispunham e que muito a ajudou como estratégia de marketing. No entanto, há que se pensar que outro fator contribuiu sobremaneira para a divulgação da Banda, a fonografia, como veremos.

\subsection{A Banda em 78 rotações}

Arriscando-se em um espaço novo criado pelas gravadoras de música, a Banda da Força Pública esteve presente nos estúdios de gravação. Conforme apontamos no capítulo 2, entre os dias 16 e 26 de junho de 1913, foram gravadas na cidade de São Paulo 82 ceras com o selo Odeon, que correspondem à série 120.000 daquela gravadora. Não se sabe ao certo qual foi o total de gravações que a Banda da Força Pública fez durante os anos da primeira República nem os anos exatos de suas produções. Há, entretanto, indícios que podem ser explorados, sendo que, por meio deles, revela-se a produção de três séries distintas. ${ }^{346}$

\footnotetext{
${ }^{345}$ A partir de 5 de dezembro de 1918, fora estabelecido um novo uniforme para uso na Força Pública, constando de gorro com pala (quepe), gandola e calças de tecido em brim na cor cáqui, acompanhando o uso de sobrecasaca marrom, como se pode observar.

${ }^{346}$ A série 108.000 foi produzida entre os anos de 1907 e 1912 e abrange a gravação de 22 fonogramas listados na tabela da discografia dessa Banda. A série 120.000, que, segundo catálogo disponível na obra de Franceschi, é localizada temporal e espacialmente em São Paulo no ano de 1913, concentra 15 dos 38 fonogramas listados. Resta, portanto, um fonograma da série X-720 da Zon-O-phone cuja atribuição de data permanece ainda
} 
Provavelmente a polca de autor desconhecido intitulada Feiticeira, foi a primeira obra gravada pela Banda da Força Pública de São Paulo entre 1902 e 1903, sendo desconhecido o local da gravação, sendo quase certo que tenha ocorrido na cidade do Rio de Janeiro. Como eram comuns as viagens da Banda da Força Pública à Capital Federal naquele início do século $\mathrm{XX}$ pelos mais diversos motivos, é provável que, em alguma delas, a Banda tenha sido convidada a gravar Feiticeira como evento experimental para a Odeon. Fato concreto, no entanto, é que somente seis a sete anos mais tarde - 1909 - a Banda voltaria aos estúdios para gravar a sequência de fonogramas que compõem a série 108.000, da qual faz parte a Marcha dos Croatas apresentada abaixo:

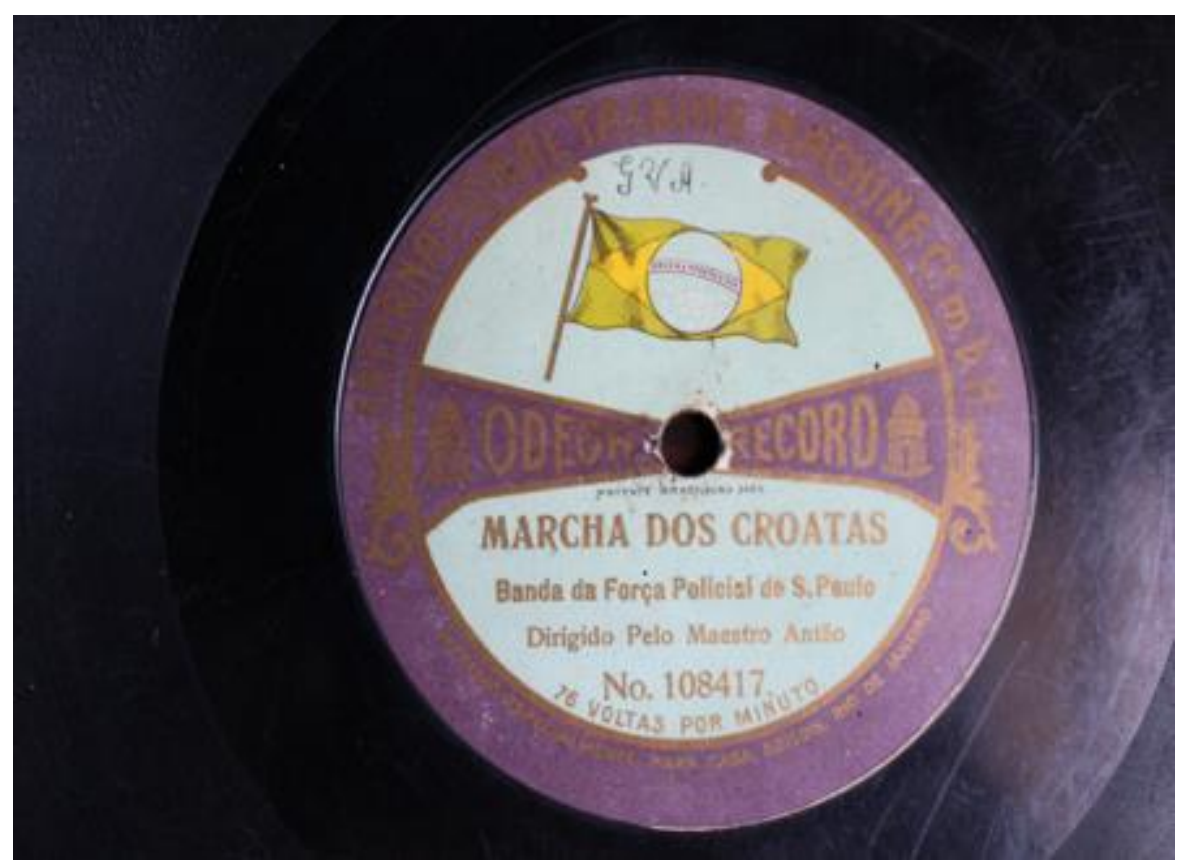

Figura 20.

Selo Comemorativo No 108417 Odeon Record - Banda da Força Pública do Estado de São Paulo. Fotografia do pesquisador em coleção de Miguel Braghioni (Porto Ferreira, fev.2018). Data aproximada do disco: 1913.

Como cada gravação produzia em média apenas 250 exemplares para cobrir os custos da produção entre os anos de 1902 a $1913^{347}$, pouquíssimos deles chegaram até nossos dias.

indefinida, porém, conforme aponta a historiografia, a possibilidade de datação insere-se entre os anos de 1902 e 1903.

${ }^{347}$ FRANCESCHI, Humberto M. A Casa Edison e seu tempo. Rio de Janeiro: Sarapuí, 2002, p.215. 
O selo acima, 108417 da Odeon Record, contém o que foi possivelmente a segunda gravação feita pela Banda de Música da Força Pública do Estado de São Paulo. Embora a edição seja comemorativa (atestada pela presença do símbolo nacional por meio da bandeira) e presumivelmente datada de 1913, trata-se de uma reedição da gravação original, feita provavelmente em 1909, conforme apontamentos de Miguel Nirez. Outras faixas, como Viúva Alegre (faixa 13 CD-1) e Ao clarão da lua (faixa 3 do CD-1), fazem parte da mesma série do rótulo de Marcha dos croatas, faixas essas gravadas, ao que tudo indica, por volta de 1909. Nelas, é possível ouvir um repertório francamente popular que, a partir do advento da indústria fonográfica, foi resgatado para compor os discos gravados pela Odeon. O CD n. 1 do encarte é composto por obras executadas pela Banda da Força Pública e traz como repertório: 1. A vassourinha (polca); 2. Amor saudoso (valsa); 3. Ao clarão da lua (mazurca); 4. Atraído por uma flor (valsa); 5. Coalhada (tango); 6. Japonês (dobrado); 7. Manuelita (polca); 8. O maxixe (maxixe); 9. Rio Branco (dobrado); 10. Titita (mazurca); 11. Tudinha (polca); 12. Valsa lenta do maestro Osvaldo (valsa); e 13. Viúva Alegre (valsa).

De certa forma, o repertório esboça as escolhas e resgatou aquele antigo repertório popular que executava no início da última década do século XIX para atender às exigências e regras do mercado fonográfico, não deixando, no entanto, de trazer Mozart, Wagner e Beethoven em seus concertos, mas, abolindo-os dos discos, conforme as fontes revelaram a partir do início da era Antão. Para equilibrar os ganhos da indústria de massa e a divulgação das bandas de música, a conta era bem simples como poderemos perceber logo mais.

Uma breve reflexão sobre o repertório antes e depois da fonografia indica algumas mudanças ocorridas nas escolhas dessas obras gravadas. Os programas de concerto coletados entre 1902 e 1930 consistem, em sua grande parte, de peças oriundas de óperas, sinfonias e demais formas eruditas. Outra informação importante que as fontes trazem é que a duração média de um programa de concerto era de, no mínimo, duas horas seguidas - por exemplo, das 20 h às 22 horas - enquanto o disco possuía míseros três minutos.

Em busca de compreender melhor as relações entre o que se tocava em público e aquilo que se gravou em disco, foram analisados três programas de concerto de cada um dos anos de 1903, 1915 e $1928 .{ }^{348}$ A análise apontou determinados padrões: o primeiro diz

\footnotetext{
${ }^{348}$ As referências foram: para 1903, concertos em 29 de janeiro, 8 de fevereiro e $1^{\circ}$ de março, todos contendo oito obras cada; para 1915, 2 de julho, 3 de agosto e 16 de setembro, todos contendo oito obras cada exceto o
} 
respeito ao repertório e aos gêneros executados, conforme exposto anteriormente; o segundo padrão relaciona-se com a formatação do concerto, que se dava sempre em duas partes com, no máximo, quatro obras em cada uma delas; e o terceiro está ligado à discrepância entre a duração de execução das obras, como analisaremos a abaixo. No escopo deste texto, abordaremos apenas o terceiro padrão.

Entre 1902 e 1915, o tempo médio estimado de execução de uma obra em concertos, era de 12’30”, com raríssimas exceções. Dessa forma, os programas seguem sempre com esses padrões e, como se pode observar, a média estava longe, portanto, dos três minutos ideais necessários para os discos de $78 \mathrm{rpm}$. Não fica difícil perceber que seria pouco prudente e comercialmente longe do rentável a uma Banda, àquele momento e com a tecnologia de que se dispunha, gravar uma abertura de $O$ Guarani de Carlos Gomes, cuja duração estimada está entre 8'30" e 9'00' em um 78 rpm capaz de suportar 3'00'.

A solução poderia ter dois caminhos: o primeiro seria gravar a obra em dois discos (uma faixa em cada lado A-B mais um segundo disco com uma faixa $\mathrm{A}$ ), dando sentido à ideia de álbum, mas que representava um custo mais elevado de produção. ${ }^{349}$ As obras integrais de concerto já estavam sendo gravadas deste modo na Europa e EUA, mas se destinavam a um público mais elitizado distante dos anseios e objetivos dessa incipiente indústria no Brasil do início do século XX. Como exemplo da tentativa de atender às diversas fatias desse mercado, a Victor definiria um pouco mais tarde o gênero e seus preços pelas cores de seus rótulos:

Com uma política de diferenciação de preços segundo a cor do selo, a Victor destinou o valor mais alto aos discos de ópera de selo vermelho. Os selos azul e roxo foram usados para repertório popular célebre com preços intermediários, e o selo preto para música de banda e comédia, sendo os discos mais baratos. Essa diferenciação terminou por lhe outorgar prestígio às gravações de música erudita do selo. ${ }^{350}$

\footnotetext{
de 16 de setembro com sete obras; para 1928, 10 de fevereiro, 16 de março e 16 de abril, todos contendo sete obras cada.

${ }^{349}$ Custo de produção mais elevado representaria um produto mais caro para o consumidor final. Provavelmente essa solução também não atendia aos anseios dessa indústria fonográfica, uma vez que os discos eram destinados a um mercado de classe média. Ao se gravar dois discos, havia grandes possibilidades de "encalhe" nas prateleiras das lojas em razão de seu custo.

${ }^{350}$ KENNEY, William Howland. Rercorded music in American life: the phonograph and popular memory, 1890-1945. New York: Oxford University Press, p. 53-54. apud GONZALES, Juliana Pérez. A indústria fonográfica e a música caipira gravada. 2018. Tese (Doutorado) - Faculdade de Filosofia, Letras e Ciências Humanas, Universidade de São Paulo, São Paulo. p. 184.
} 
O segundo caminho seria não gravar esse tipo de grupo musical. A questão é que, dessa forma, o potencial comercial também seria desperdiçado. Surgia, portanto, uma outra pergunta: o que gravar dentro dos padrões de tempo disponibilizados pela indústria fonográfica a fim de aproveitar tal potencial comercial? Antes da apresentação de uma hipótese de resposta a essa pergunta, é necessário verificar algumas das obras gravadas pela Banda da Força Pública e sua respectiva contagem de tempo:

$\begin{array}{ll}\text { 1. A Vassourinha } & 4^{\prime} 18^{\prime \prime} \\ \text { 2. Amor saudoso } & 2^{\prime} 55^{\prime \prime} \\ \text { 3. Ao clarão da Lua } & 3^{\prime} 06^{\prime \prime} \\ \text { 4. Atraído por uma flor } & 2^{\prime} 49^{\prime \prime} \\ \text { 5. Coalhada } & 2^{\prime} 58^{\prime \prime} \\ \text { 6. Japonês } & 3^{\prime} 10^{\prime \prime} \\ \text { 7. Manuelina } & 3^{\prime} 04^{\prime \prime} \\ \text { 8. O Maxixe } & 3^{\prime} 20^{\prime \prime} \\ \text { 9. Rio Branco } & 2^{\prime} 53^{\prime \prime} \\ \text { 10. Titita } & 2^{\prime} 51^{\prime \prime} \\ \text { 11. Tudinha } & 3^{\prime} 18^{\prime \prime} \\ \text { 12. Valsa lenta do maestro Oswaldo } & 2^{\prime} 54^{\prime \prime} \\ \text { 13. Viúva alegre } & 2^{\prime} 53^{\prime \prime} .351\end{array}$

Dos 13 exemplos gravados e apresentados acima, apenas A Vassourinha é um pouco maior que 4'00"; entretanto, a maioria das obras (12) são curtas o suficiente para serem acomodadas nos discos de $78 \mathrm{rpm}$, levando-se em conta ainda que todas as músicas gravadas traziam seu anúncio ao início, o que tomava entre 6 e 10 segundos, prejudicando ainda mais o curto espaço de tempo que havia. ${ }^{352}$

\footnotetext{
351 Todas as obras citadas fazem parte do CD n. 1 que acompanha este trabalho.

${ }^{352}$ Vale lembrar que as 78 rotações somente foram padronizadas a partir da fase elétrica das gravações, ou seja, após 1927, uma vez que, na mecânica, as rotações variavam entre 66 e $82 \mathrm{rpm}$ e, dependendo do andamento utilizado pelo intérprete, essas acomodações de tempo passavam a se constituir um problema menor, ajustandose entre rotações e andamentos o tempo necessário para que a obra coubesse dentro do disco.
} 
O grande ponto, entretanto, é que o que se gravou não era o que se tocava nos concertos - e isso vale para todas as bandas cujos repertórios de concertos e de discos conseguimos comparar, conforme os Cds n. 1, 2 e 3 do encarte. Há, portanto, ao que parece, dois tipos de repertórios específicos: aquele dos discos e da indústria; e aquele dos concertos ao vivo.

O problema de acomodação de um repertório de concerto contendo músicas muito extensas acompanhou as bandas desde os primórdios das gravações até a chegada do LP, desenvolvido na Columbia Records no final dos anos 1940, quando o novo formato passou a possibilitar, em média, 25'00" de música gravada em cada lado, fazendo com que as obras eruditas pudessem, finalmente, aparecer pelas transcrições das bandas de música. Quanto aos 78 rpm, pode-se inferir que, se nos tempos de Figner e da Odeon, as músicas de concerto tinham uma duração média quatro vezes maior do que a partir das gravações, o repertório que foi para indústria e o consumo de massa teve de se desengavetado pelas bandas. ${ }^{353}$ Essa adaptação não se deu no sentido dos arranjos musicais, transcrições ou temas, mas sim da execução. As bandas foram obrigadas a resgatar um repertório que saíra de cena desde os idos de 1890-1895, retrabalhando-o ou (re)produzindo-o para gravar nos discos, limitando as músicas aos três minutos padrão. Dessa forma, podia-se atender às demandas da indústria dentro das restrições de tempo impostas por aquela tecnologia, com objetivos claramente mercadológicos: oferecer música popular, mais próxima do consumidor. Os objetivos da indústria eram os de agradar e seduzir o ouvinte, e criar tendências de consumo que se encaixassem à capacidade de produção, vendas e, consequentemente, lucro.

Para impulsionar o processo de massificação, a chegada dos gramofones por volta da primeira década do século XX foi crucial e acelerou toda uma cadeia de produção e consumo da música gravada, substituindo os cilindros dos fonógrafos pelos discos de goma-laca. Os gramofones mudaram alguns hábitos de escuta musical, como foi abordado no capítulo anterior. Assim, quem quisesse ouvir Wagner deveria comparecer aos concertos no Jardim da Luz, Jardim do Palácio, Parque da Cantareira ou até à esplanada do Teatro Municipal onde possivelmente não se ouviria Tudinha e, muito menos, Maxixe. Nos 217 programas que são contemplados pelas análises deste estudo, cobrindo o período que vai entre 1902 e 1930,

\footnotetext{
${ }^{353}$ O mesmo processo seria vivenciado com a música "caipira" a partir de 1929, conforme aponta GONZALES, Juliana Pérez. A indústria fonográfica e a música caipira gravada. 2018. Tese (Doutorado) - Faculdade de Filosofia, Letras e Ciências Humanas, Universidade de São Paulo, São Paulo. p. 24-25.
} 
ambas não foram encontradas. ${ }^{354}$ Por outro lado, Wagner, Bach e Beethoven também não estão presentes nas tabelas da discografia, corroborando a ideia de readaptação de um novo repertório em função desse mercado. ${ }^{355}$ No entanto, é possível ainda que novas fontes tragam à luz gravações de música de concerto que ainda permanecem incógnitas.

Não se pode esquecer que a quase totalidade desses documentos sonoros, no entanto, foi produzida entre os anos de 1909 e 1913. Porém, não é possível afirmar que a Banda não tenha gravado novamente a partir da segunda metade da década de 1910. Ao que parece, a década de 1920 trouxe outras preocupações não apenas às bandas de música, mas também para o país em geral, incluindo, é claro, sua cultura. Em suma, o disco e as viagens para o interior do estado de São Paulo aceleraram a divulgação dos trabalhos da Banda. Todavia, conforme vimos, o disco trouxe uma lógica de mercado segundo a qual o que importou foram os lucros e não a estética. Ao gravar músicas que não se tocavam nos coretos, a indústria promovia boas vendas, compensando os investimentos, porém, paulatinamente, como vimos no capítulo 2, retirou parte do som das ruas e o direcionou para o ambiente privado.

\section{Agitato: os tumultuados anos 1920}

Dividindo-se entre a cidade de São Paulo, a Capital Federal e o interior do estado, a Banda de Música da Força Pública ingressou nos anos $20 \mathrm{em}$ um andamento acelerado. Ao que nos parece, as boas expectativas propiciadas pelo término da Grande Guerra, o surto de desenvolvimento industrial que a cidade viveu, a melhora na economia do café e as possibilidades de crescimento para a década de 1920, foram fatores de entusiasmo para o ambiente cultural da cidade. Tudo levava a crer que seria uma década de retomada da expansão das atividades musicais - pelo menos no ambiente interno da Banda. Todavia, tal expectativa não se configurou.

Além dos conflitos políticos dos anos 1920, que elevaram as tensões na cidade, os preparativos das comemorações do primeiro centenário da independência, que seria realizado

\footnotetext{
354 Agradeço à historiadora Virgínia de Almeida Bessa pelos conselhos, discussões e apontamentos sobre o repertório de concerto das bandas e sua duração em contraste com o repertório delas a partir do advento da indústria fonográfica.

355 Conforme dito anteriormente, pelos resultados obtidos em levantamento prévio realizado durante o desenvolvimento desta pesquisa, é possível afirmar que a produção fonográfica da Banda de Música da Força Pública desde o início das gravações até os dias de hoje ultrapassa os 100 discos, incluindo 78 rpm, 45 rpm, compactos, LPs, CDs e hodiernamente DVDs.
} 
com grande pompa em 1922, aumentaram as expectativas da Banda. Em suas memórias, Antão ${ }^{356}$ descreve aquele Sete de Setembro como "um dia de glória". Em frente ao monumento do Ipiranga, foi organizado um concerto musical sob sua condução. Foram reunidas a Banda da Força Pública e outras bandas convidadas, além de um conjunto de quatro mil escolares da rede pública de ensino do estado e de um efetivo de 500 soldados da Força Pública, que, juntos e ensaiados, formaram um grande coro. Todo esse contingente interpretou o Hino Nacional Brasileiro e o poema sinfônico O Centenário, escrito, conforme relata Antão, a seu pedido, pelo maestro Savino De Benedictis, com letra de Henrique Macedo. A edição de 8 de setembro (o dia seguinte ao evento) do Correio Paulistano traz informações complementares sobre os músicos empregados no evento: Banda da Força Pública completa, Banda Musical de Jaú, Banda Musical de Araras, Banda Musical de São Roque, Banda Musical de Salto de Itu e Banda Musical Giuseppe Verdi da capital, acompanhadas de 70 professores de orquestra, 50 corneteiros, 50 clarins e 50 tambores. ${ }^{357}$

Vale lembrar que esse não foi o único evento comemorativo na cidade - houve solenidades no Palácio dos Campos Elíseos com participação de outras bandas militares, por exemplo -, mas, em termos de grandiosidade, de longe foi o que mais marcou a população, sobretudo pela inauguração na mesma ocasião do monumento à Independência do Brasil, de autoria dos artistas Ettore Ximenes e Manfredo Manfredi.

Como já abordado nos capítulos anteriores, a década de 1920 trouxe uma expansão considerável no campo da oferta de trabalho para os músicos. Cafés, restaurantes, cafésconcertos, cinemas, cabarés, conjuntos de bailes e salões de todos os tipos passaram a ofertar oportunidades em maior número, promovendo um certo efeito perverso para as bandas militares. ${ }^{358}$ Já vimos que os salários da Força Pública sempre estiveram longe de serem atraentes; porém, pela constância e regularidade de seus pagamentos, essas bandas eram procuradas pelos músicos da capital e até mesmo do interior a fim de garantir o mínimo de dignidade para si e seus dependentes. Mas, em 1923, a Banda da Força enfrentou a primeira

\footnotetext{
${ }^{356}$ FERNANDES, Joaquim Antão. Minha autobiografia. São Paulo: s/editora, 1943. p. 16. Mimeografado.

357 O Centenário. Correio Paulistano, São Paulo, p. 4, 8 set. 1922.

$358 \mathrm{O}$ efeito perverso restringia-se apenas às bandas de música militares, em razão de seu regime de trabalho e horário de serviço (dedicação exclusiva), que dificultava a prestação de serviços em outras organizações musicais ("bicos”), como forma de complementação da renda. Em bandas civis, essa era uma prática comum desde há muito tempo. A escolha de deixar as bandas militares muito provavelmente estava calcada, portanto, no salário e nos horários.
} 
de várias crises de desabastecimento de mão de obra. Os músicos, atraídos por melhores ofertas de emprego e salários, deixavam as fileiras da Banda para ingressar em outros grupos musicais. Vale lembrar que, ao longo de sua existência, a Banda da Força recorrentemente lutou contra alguns "fantasmas" e esse foi um dos que sempre esteve presente. Para dirimir seus efeitos, algumas medidas foram tomadas por parte do comando da banda e da corporação: o aumento de gratificação provisória e dos salários mensais do pessoal efetivo; convocação de interessados por todo o estado; ${ }^{359}$ e intensificação do ensino de música aos aprendizes da Banda e aprendizagem de música aos soldados de outras armas da Força Pública, desde que estes quisessem pertencer à Banda.

Se o início dos anos 1920 foram desafiadores para a Banda, em um aspecto ao menos evidenciou-se certa valorização da carreira de músico dentro da Força Pública. A partir de

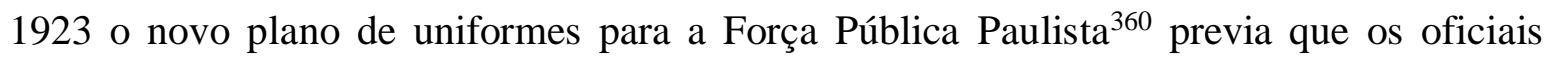
músicos utilizassem as liras como símbolo de seu quadro. ${ }^{361}$ Estabelecia que as dragonas (ombreiras) do inspetor e subinspetor da Banda de Música conteriam, na parte superior, um botão dourado com uma lira e, no centro da palmatória, haveria uma lira de metal dourado de três centímetros de comprimento. O mesmo passou a valer para todos os demais uniformes. Assim como os médicos passaram a usar o caduceu, farmacêuticos a ânfora com a serpente, os dentistas a cobra ondeando uma haste, os oficiais músicos estavam ao mesmo tempo distinguidos e em pé de igualdade com os demais especialistas que compunham os quadros da instituição mantenedora. Nesse sentido, se a roupa era sinal de distinção e os oficiais formavam uma classe, o regulamento ratificou que, dentro dela, havia também lugar para os músicos, adotando simbolicamente sua representação pela insígnia.

Longe de ter sido um tempo de tranquilidade, como se sabe, os conflitos políticos e militares de 1924 transtornaram o cotidiano da cidade, sobretudo durante o mês de julho, quando vários confrontos bélicos ocorreram. Os eventos da revolta causaram impacto direto na Força Pública de São Paulo, abalando também as estruturas de sua Banda de Música. O

\footnotetext{
359 DELla MONICA, Laura. História da Banda de Música da Polícia Militar do Estado de São Paulo. São Paulo: Edanee, 1975. p. 67.

${ }^{360}$ Decreto s/n. de 30 out. 1923. Dispõe sobre o plano de uniformes da Força Pública do Estado de São Paulo a que se refere o decreto desta data. ALESP, São Paulo, 1923.

361 Conforme o regulamento de uniformes vigente atualmente na Polícia Militar do Estado de São Paulo, o símbolo da arma de música ainda é uma lira dourada usada nas golas das camisas, de acordo com o estabelecido para cada tipo de uniforme, sendo obrigatório seu uso pelos oficiais músicos.
} 
movimento contou com o apoio do major Miguel Costa, à época fiscal do Regimento de Cavalaria da Força Pública. Amigo de longa data do maestro Antão, Miguel Costa alinhavase com os ideais tenentistas, tornando-se posteriormente parceiro do capitão do Exército brasileiro Luiz Carlos Prestes. Embora Antão se dissesse legalista, conforme relata em suas memórias, não conseguiu apresentar-se às forças legais, porque a Ponte Grande ${ }^{362}$ estava sob o poder dos revoltosos. Por esse motivo, teria permanecido em sua casa no bairro de Santana, durante os primeiros dias do movimento. ${ }^{363}$ Em 9 de julho, sabendo da notícia de transferência do governo para a estação de Guaiaúna e estando o Quartel da Luz franqueado ao povo e sob o poder dos revolucionários, Antão dirigiu-se para lá, tentando conversar com seu amigo, sem conseguir falar em razão do grande número de pessoas e admiradores que o cercavam. No dia seguinte, 10 de julho, Antão conseguiu conversar com Miguel Costa e dirigiu-se à sala da Banda, lá encontrando apenas alguns músicos que, em um primeiro momento, informaram-lhe que estava "tudo em ordem". Retirou-se e só retornou ao quartel no dia em que os revoltosos deixaram a cidade (28 de julho). Ao apresentar-se às forças federais que ocuparam São Paulo, logo após a saída dos revoltosos, Antão recebeu voz de prisão. Foi recolhido à cadeia pública, tendo nela permanecido por alguns dias. Ouvido pela comissão de sindicância, foi liberado mesmo reconhecendo como seu um bilhete que havia sido interceptado pelas forças legalistas, bilhete esse escrito a punho próprio e endereçado ao major Miguel Costa, o qual provava suas estreitas relações com o amigo. Nele, Antão pedia a intercessão do major para a compra de gêneros alimentícios no armazém reembolsável da Força, uma vez que estes começavam a faltar na cidade e, mediante sua autorização por escrito, a aquisição desses gêneros poderia se fazer sem óbice. Na verdade, para as forças legalistas, o bilhete representou a prova necessária de sua coparticipação no movimento revoltoso, o que lhe rendeu algumas noites dormidas no cárcere e seu afastamento da condução da banda de música a partir de 28 de julho.

Reapresentado ao quartel, Antão tomou ciência de que, durante sua ausência, fora nomeado para substituí-lo interinamente, na função de inspetor da Banda de Música, seu subinspetor, o $1^{\circ}$ tenente Benedicto de Assis Lorena. A partir de então, Lorena assumiu o comando da Banda e Antão passou a sofrer pressões para que apresentasse voluntariamente

\footnotetext{
362 Ponte grande erguida por volta de 1700, é a atual Ponte das bandeiras que ligava a zona norte da cidade (Santana) ao centro.

${ }^{363}$ FERNANDES, Joaquim Antão. Minha autobiografia. São Paulo: s/editora. 1943 p. 16-17. Mimeografado.
} 
seu pedido de reforma, o que veio efetivamente a fazer após um ano de licença fruído a contar de 19 de fevereiro de $1925,{ }^{364}$ conforme publicação de 8 de março de $1926 .{ }^{365}$ Para Lorena, foi igualmente difícil reestruturar a Banda de Música, uma vez que, para a própria instituição mantenedora, o movimento fora confuso e as praças da Força Pública pouco entenderam o que havia ocorrido. Vários músicos desapareceram (fugiram para o interior do estado), outros aderiram à causa revolucionária seguindo com a Coluna e outros permaneceram legalistas. De fato, somente após o afastamento de Antão e a assunção de Lorena, a Banda retornou paulatinamente a seu ritmo de atividades com o consequente, porém vagaroso, retorno de seus músicos. A Banda havia sim trocado de mãos e o tenente Benedicto de Assis Lorena, pôde - ainda que, por pouco tempo - impor um ritmo de modernização à corporação.

Em $1^{\circ}$ de janeiro de 1925, a Banda era movimentada para o Batalhão-Escola da Força Pública, e Lorena, já promovido a capitão, passou a ter como seu $2^{\circ}$ tenente auxiliar, Salvador Chiarelli, que anos antes viera da Banda do Corpo de Bombeiros. ${ }^{366}$ Em agosto, Salvador Chiarelli foi promovido a $1^{\mathrm{o}}$ tenente (subinspetor) ${ }^{367} \mathrm{e}$, em outubro, Narciso Giuliano, foi promovido a $2^{\circ}$ tenente auxiliar. ${ }^{368}$

No entanto, o maior feito de Lorena estaria nas alterações que conseguiu promover no Quadro Particular de Organização da Banda de Música consagradas pela edição da Lei n. 2.128-A, aumentando-se o efetivo das praças na seguinte conformidade: foram acrescidas duas vagas de $1^{\circ}$ sargento músico de classe distinta, seis vagas de $2^{\circ}$ sargento músico de primeira classe, dez vagas de soldado músico de primeira classe, e 12 vagas de soldado músico de terceira classe, resultando em praticamente uma Seção de Banda a mais para a Força Pública. Reflexo de uma política de valorização profissional pelas mãos de Lorena, a Banda a partir de então passava a ter a soma de 93 figuras, podendo ser fracionada em três Seções (desde que seu efetivo estivesse completo, é claro), com a possibilidade de atendimento de três serviços distintos simultaneamente, o que a transformava também no maior conjunto musical de sopros da cidade de São Paulo, quando completo.

\footnotetext{
${ }^{364}$ Boletim Geral, Força Pública do Estado de São Paulo. São Paulo, n. 39, p. 308, 18 fev. 1925.

365 Boletim Geral Força Pública do Estado de São Paulo. São Paulo, n. 50, p. 463, 8 mar. 1926.

${ }^{366}$ Boletim Geral, Força Pública do Estado de São Paulo. São Paulo, n. 1, p. 3, 1 jan. 1925.

${ }^{367}$ Boletim Geral, Força Pública do Estado de São Paulo. São Paulo, n. 181, p. 357, 18 ago. 1925.

368 Boletim Geral, Força Pública do Estado de São Paulo. São Paulo, n. 227, p. 768, 16 out. 1925.
} 
Em 1926, Lorena se despediu sem dizer adeus. No espaço interno do Quartel da Luz, havia as salas da Banda de Música e outra sala na qual eram guardados relíquias e troféus da Revolução de julho de 1924, sob os cuidados do major Nathaniel Prado e do cabo Pedro Américo de Freitas. Lá havia granadas descarregadas, um projétil de canhão 105 mm e uma bomba de picrato de potássio pesando aproximadamente 75 quilos, que, não se sabe o motivo, não havia ainda sido desarmada. Por volta das 15 h do dia 27 de maio de 1926, ao tentar desarmar a referida bomba, o cabo Pedro Américo provocou uma explosão que levou consigo as salas da Banda de Música, a sala dos troféus e a sala de armas do quartel. O impacto da explosão jogou o major Nathaniel Prado e o capitão Lorena para o meio do pátio interno, ceifando suas vidas, além das do $1^{\circ}$ sargento músico Domingos Arnaldo Pirolllo e do próprio cabo Pedro Américo. Quatro praças do $1^{\circ}$ Batalhão de Infantaria também ficaram mutilados. ${ }^{369}$ Em 29 de maio (dois dias após a explosão), o Boletim Geral da Força Pública ${ }^{370}$ trazia o laudo sobre os mortos e feridos do acidente. A missa de $7^{\circ}$ dia, celebrada na igreja de Santa Efigênia, foi realizada às 9 h de 2 de junho daquele ano, e contou com a presença dos músicos da Banda que Lorena comandava há pouco menos de um ano. Após o acidente, o comandante do Batalhão-Escola foi nomeado inspetor interino da Banda de Música, exercendo cumulativamente ambas as funções até 1927 , porém o $1^{\circ}$ tenente músico Salvador Chiarelli passou na prática a responder pela regência por ser o próximo na linha sucessória daquela função.

Naquele ano de 1926, porém, antes do fatídico episódio que resultara na morte do maestro Lorena, a banda vinha cumprindo uma agenda considerável. Somente pelos números do Boletim Geral da Força Pública dos meses de janeiro a maio, foi possível mapear mais de 20 apresentações, além dos serviços rotineiros dos quartéis e, apesar do ocorrido, a rotina profissional da Banda também não foi alterada nos meses seguintes, conforme mostram as fontes. Fechando o ano com mais de 40 apresentações externas, é possível compreender que, apesar do desastre que ceifou a vida de Lorena, a Banda permaneceu cumprindo seu papel

\footnotetext{
369 TELHADA, Paulo Adriano Lucinda Lopes. Quartel da Luz - mansão da ROTA: histórias do Batalhão Tobias de Aguiar. São Paulo: Just Editora, 2011. p. 284-290.

${ }^{370}$ Força Pública do Estado de São Paulo. Boletim Geral, São Paulo, n. 115, p. 1000-1002, 29 mai. 1926.
} 
dentro da instituição e da vida musical da cidade enquanto nos Batalhões sediados no interior do estado, novas Bandas Regimentais começavam a surgir. ${ }^{371}$

Um dos desdobramentos da crise que se abateu sobre a Força Pública durante os anos que se seguiram ao movimento de 1924 foi a criação da Guarda Civil de São Paulo. Embora alguns autores ${ }^{372}$ encarem seu surgimento como a recriação de outra instituição que fora extinta em 1924 (a Guarda Cívica), suas origens podem estar associadas à Guarda de Urbanos, sucessora da Companhia de Pedestres, criada inicialmente no longínquo ano de 1850. Todas foram corporações policiais de caráter civil que tinham por função o policiamento urbano a pé e que, retomadas de tempos em tempos, eram reorganizadas de acordo com as necessidades políticas e o aumento pela demanda de policiamento na cidade e no estado. Todavia, é possível que Carlos de Campos tenha tomado a medida de criar a Guarda Civil de São Paulo, em 1926, em razão de seu relacionamento problemático com a Força e a liderança do major Miguel Costa envolvido com o movimento tenentista.

A Guarda Civil de São Paulo era uma instituição policial de caráter estatal permanente, não possuindo quase nada em comum com a Força Pública. Idealizada nos moldes da polícia inglesa e, como seu próprio nome dizia, civil, também tinha uniformes que

\footnotetext{
${ }^{371}$ Alguns batalhões da Força Pública sediados no interior do estado passaram a cultivar bandas de música na informalidade, assim como se dera na São Paulo do final do século XIX e início do XX. Iniciando como bandas de cornetas e tambores (denominadas fanfarras), aos poucos foram ganhando corpo e se profissionalizando, no mesmo caminho da banda da capital, porém sem o respaldo legal e administrativo do conjunto paulistano. Uma, no entanto, é mais antiga e remonta ao último ano do século XIX. Trata-se da Banda de Santos, datada de 1899, celeiro de muitos músicos e várias bandas civis. Quando de sua fundação, a Banda pertencia ao Corpo de Bombeiros Municipal, sendo absorvida pela Força Pública somente no primeiro quartel do século XX. Em 1926, foi criada a Banda Regimental de Música na cidade de Campinas, cuja companhia da Força Pública pertencia ao $3^{\circ}$ Batalhão de Infantaria. Na década seguinte, floresceria um maior número dessas corporações, formando-se bandas no $7^{\circ}$ Batalhão de Caçadores Paulistas, sediado em Itapetininga (1934), no $3^{\circ}$ Batalhão de Caçadores Paulistas, em Ribeirão Preto (1938), e no $5^{\circ}$ Batalhão de Caçadores Paulistas da cidade de Taubaté (1939). Outro caso curioso foi uma Jazz Band existente no $2^{\circ}$ Regimento de Cavalaria, sediado na cidade de Presidente Wenceslau. Sem tomar parte formal no efetivo daquele Regimento, o conjunto atuou durante a década de 1920 e foi desativado, ao que tudo indica, em 1930. Em 14 de outubro daquele ano, o comandante daquela organização militar enviou um ofício ao Prefeito de Presidente Wenceslau, no qual apresentava uma relação de instrumentos musicais pertencentes à prefeitura que, mediante empréstimo, estavam à disposição da Banda do Regimento. Devolvidos à Câmara Municipal daquela cidade, tomaram o destino de prover outras necessidades musicais do município. Na relação, constavam: um bombardino, um bombo com maçanetas, um baixo, duas clarinetas, uma caixa com maçanetas, um pistão, dois saxes de harmonia, um trombone de vara, uma requinta e dois pratos. Pela relação dos instrumentos, não se pode afirmar tratar-se de uma Jazz Band (forma como o documento trata o conjunto musical); ao contrário, pelas características do instrumental devolvido, é mais provável tratar-se de uma pequena banda com 12 ou 13 músicos que atendiam aos serviços da caserna.

${ }^{372}$ FERNANDES, Heloisa. A Força Pública dos Estado de São Paulo. In: FAUSTO, Boris; HOLANDA, Sérgio Buarque (Coord.). História geral da civilização brasileira. Tomo III, v. 2, São Paulo: Difel, 1977. p. 240 e 248.
} 
nem de longe lembravam os da Força. Aos poucos, a Força Pública foi deixando as ruas dos bairros nobres devido ao aquartelamento decretado por um rígido regulamento policial editado em 1928. ${ }^{373}$ Tal regulamento remeteu a Força Pública, conforme seu art. $10^{\circ}$, a um caráter de "instituição auxiliar" da administração policial ${ }^{374}$. O policiamento das diversões públicas ficou a cargo da Guarda Civil, assim como o patrulhamento a pé nos bairros do centro da cidade. Além dos uniformes, havia outra diferença evidente entre o efetivo que compunha essa nova polícia e o efetivo da Força Pública do Estado: na Guarda Civil, a admissão só era possível se o candidato fosse alfabetizado. Dessa forma, criava-se uma distância social entre os efetivos dessas duas corporações policiais.

Uma das medidas adotadas pela administração da Guarda Civil de São Paulo logo em seu início foi a formação de sua Banda de Música, o que veio a ocorrer em 1928. Com um efetivo de 25 figuras, a referida Banda tinha à frente, a partir de então, na função de maestro, o $2^{\circ}$ sargento da Força Pública Miguel de Marca, que, transferido da Força Pública para a Guarda Civil, passou a regê-la até 1931, quando o maestro Carlos Lombardi assumiu definitivamente sua coordenação. ${ }^{375}$ Em 1934, foi aberto o alistamento de candidatos músicos para o ingresso direto nas fileiras da Banda da Guarda Civil. ${ }^{376}$

${ }^{373}$ Decreto n. 4405-A de 17 de abril de 1928. Dá regulamento às leis no s.2.034 de 30 de dezembro de 1924; 2.172-B de 28 de dezembro de 1926; 2.210 de 28 de novembro de 1927 e 2226-A de 19 de dezembro de 1927 e consolida as disposições vigentes relativas ao serviço policial do Estado e às atribuições das respectivas autoridades. ALESP, São Paulo, 1928.

${ }^{374}$ Um ponto importante a se destacar sobre a recém-criada Guarda Civil do Estado de São Paulo foi sua subordinação: estava ligada administrativamente ao Chefe de Polícia e, portanto, à Polícia Civil do Estado e não à Secretaria da Justiça, como a Força Pública. Esse status e subordinação somente mudaria a partir da década de 1930, com a criação da Secretaria de Segurança Pública e posteriormente a edição do Decreto-Lei n. 217 de 8 de abril de 1970, quando unificando-se à Força Pública do Estado, ambas as corporações passaram a formar a Polícia Militar do Estado de São Paulo, cuja subordinação foi remetida à Secretaria da Segurança Pública do Estado, conforme $\S$ único do Art. $1^{\circ}$ do referido diploma legal.

${ }^{375}$ DELla MONICA, Laura. História da Banda de Música da Polícia Militar do Estado de São Paulo. São Paulo: Edanee, 1975. p. 72-74.

${ }^{376}$ Decreto-Lei 6885 de 29 dez. 1934. Reorganiza a Guarda Civil de São Paulo. ALESP, São Paulo, 1934. 


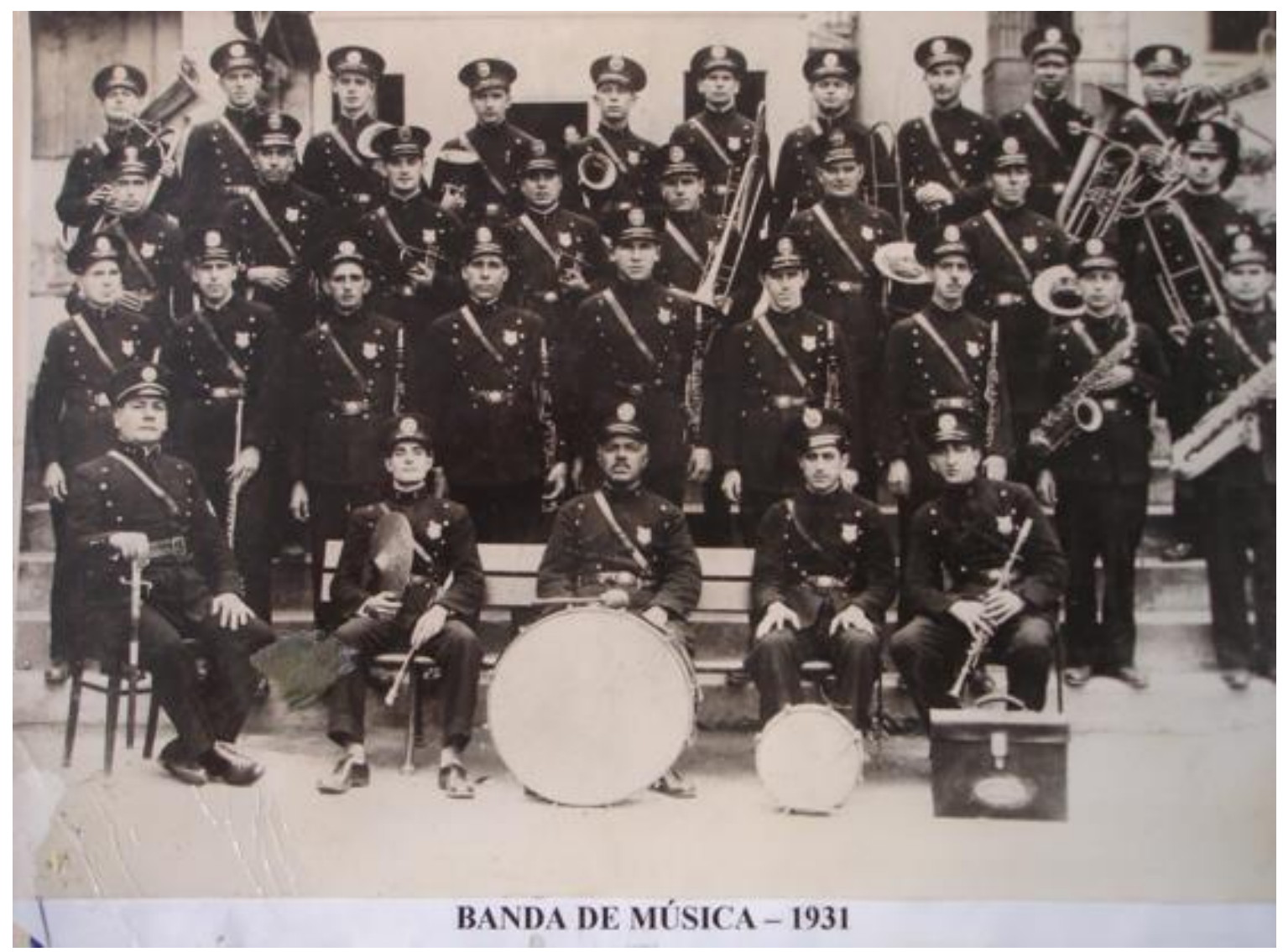

Figura 21

Banda de Música da Guarda Civil de São Paulo - 1931.

Fonte: Acervo fotográfico do Corpo Musical da Polícia Militar do Estado de São Paulo. Autoria desconhecida.

Na fotografia acima da banda da Guarda Civil, é possível verificar a presença de uma massa instrumental bem equalizada e definida. Em um total de 31 músicos, um terço aproximadamente compõe o naipe das madeiras (flautas, clarinetas e dois saxofones, sendo um em $\mathrm{E} b$ e outro em $\mathrm{B} b$ ), conferindo à Banda um timbre forte, porém, bem mais suave que aquele de suas concorrentes àquele momento. Diferindo da sonoridade áspera das bandas militares, sua percussão é o básico, porém, o essencial: bombo, pratos e caixa clara. Os metais contêm trombones, trompetes e a família dos Horns, contando com duas tubas de marcha, que reforçam o calibre grosso. Das 32 figuras (incluindo o maestro), duas aparentam ser mestiços e uma ser negro, o que pode de forma implícita representar a exclusão desses grupos 
devido à questão da alfabetização necessária para o ingresso, conforme apontado anteriormente $^{377}$.

Em 1927 finalmente foi nomeado oficialmente o novo inspetor da Banda de Música, o $1^{\circ}$ tenente músico Salvador Chiarelli. ${ }^{378}$ Em 25 de maio daquele ano, o maestro criou a Jazz. Band Cruz Azul, composta por músicos das próprias seções da Banda com a finalidade de atender a solenidades em locais fechados e buscando arrecadar fundos para a Cruz Azul criada em 1925, como exposto no capítulo anterior. Em 15 de junho, o conjunto rumaria para Rio Claro a fim de promover um baile no Salão Philarmônica daquela cidade em benefício à entidade. Seria o início de uma longa série de eventos nos quais o Jazz Band tomou parte.

Reflexo ainda de uma nova crise por falta de mão de obra que se abateu sobre a Banda de Música naquele ano de 1927, a partir de julho, suas Seções foram reduzidas:

Verificando-se diminuição continua de figuras nas tres secções da banda de musica, o senhor commandante de (sic) B. E. providencie no sentido de que, emquanto perdurar esse estado de carencia de elementos para a banda, seja a mesma constituida de duas secções somente. ${ }^{379}$

A exemplo da crise anterior iniciada em 1923, esta nova crise de 1927 foi produzida pelos mesmos motivos: os músicos seguiam para outras opções melhores de salário na cidade. Cafés, cafés-concerto, lojas de instrumentos, fábricas, lojas de discos e gramofones, conjuntos de bailes, escolas de música e bandas civis onde os rigores da caserna passavam longe eram ainda lugares mais atraentes para esses músicos do que uma banda de quartel. Como consequência das vagas deixadas abertas, uma lei publicada em novembro de 1927 alterou novamente o quadro de pessoal da Banda, transferindo essas vagas em claro para a infantaria, e o conjunto novamente foi remodelado, de acordo com a realidade que a Banda enfrentava àquele momento. A nova organização prevista pela Lei ${ }^{380}$ trouxe a perda de 29 vagas conseguidas a duras penas pelas mãos de Lorena poucos anos antes. Pela nova

\footnotetext{
377 A Banda de Música da Guarda Civil prestaria serviços à sua instituição mantenedora e à cultura musical paulistana até 1970, quando, em função da unificação à Força Pública, ambas as instituições tornar-se-iam a atual Polícia Militar do Estado de São Paulo. Sua produção fonográfica, bem vasta e toda gravada a partir da fase elétrica, contém aproximadamente 50 discos. Unificadas, as Bandas das duas instituições policiais seriam uma só, angariando um número considerável de músicos, numa banda sinfônica de 120 componentes, em três Seções com 25 músicos cada, além das 14 Bandas Regimentais de Música no interior do estado.

${ }^{378}$ Boletim Geral, Força Pública do Estado de São Paulo. São Paulo, n. 1, p. 3, 3 jan. 1927.

${ }^{379}$ Boletim Geral, Força Pública do Estado de São Paulo. São Paulo, n. 145, p. 1.237, 8 jul. 1927.

${ }^{380}$ Lei n. 2.206-A de 19 nov. 1927. Reorganiza a Força Pública do Estado de São Paulo. ALESP, São Paulo, 1927.
} 
configuração, a Banda continuava a conter um capitão na função de inspetor, um $1^{\circ}$ tenente na função de subinspetor e um $2^{\circ}$ tenente na função de auxiliar da Banda de Música. Quanto aos músicos, o documento previa um sargento ajudante músico auxiliar, quatro $1^{\circ}$ sargentos músicos de classe distinta, doze $2^{\circ}$ sargentos músicos de $1^{\text {a }}$ classe, 20 soldados músicos de $2^{\text {a }}$ classe e 24 soldados músicos de $3^{\text {a }}$ classe. Novamente dividida em duas Seções por falta de músicos, a Banda que se apresentara nos Prados da Mooca pela última vez ${ }^{381}$ era menor e mais compacta, porém apta ainda ao cumprimento de seus objetivos institucionais e culturais.

A renovação de um contrato firmado entre a Banda de Música e a Prefeitura da cidade de São Paulo em 22 de fevereiro de $1928^{382}$ possibilitou um pequeno e breve retorno à rotina das décadas anteriores, com o restabelecimento dos concertos no Jardim da Luz e na esplanada do Teatro Municipal (Parque do Anhangabaú). Esse fato pode em parte esclarecer o grande número de apresentações que ocorreram durante aquele ano. ${ }^{383}$ No entanto, concomitantemente a isso, no âmbito interno da instituição, mais um efeito perverso dos movimentos iniciados em 1922 estava em andamento. Em abril, um novo regulamento para o serviço policial mudava o status da Força Pública para "Órgão Auxiliar da Administração Policial". ${ }^{384}$ Após uma troca de comando, o novo comandante - Cel. Joviniano Brandão tomou como uma de suas primeiras medidas em relação à Banda de Música, regulamentar a situação funcional do maestro Salvador Chiarelli. Em 29 de maio (seis dias após ter assumido), promoveu-o a capitão inspetor, assim como Narciso Juliano também fora promovido a $1^{\mathrm{o}}$ tenente subinspetor. ${ }^{385}$ Dessa forma, ficava aberta uma vaga de $2^{\mathrm{o}}$ tenente auxiliar, para a qual, com o apoio do novo comandante geral, haveria de se realizar o primeiro concurso que se tem registro para o provimento do cargo de oficial músico. ${ }^{386}$ Autorização

\footnotetext{
${ }^{381}$ A partir de 1928, as comemorações mudaram de local, passando em princípio para as colinas do Ipiranga.

${ }^{382}$ Força Pública do Estado de São Paulo. Boletim Geral, São Paulo, n. 44, p. 361, 23 fev.1928.

${ }^{383}$ Em 1928, foi possível coletar 43 programas de concertos, conforme mostra a Tabela 13 de repertório. Da década de 1920, aquele ano foi o mais produtivo para a Banda de Música.

${ }^{384}$ Decreto n. 4.405-A de 17 abr. 1928. Dá regulamento ás leis no ${ }^{\circ} 2.034$, de 30 de Dezembro de 1924; 2.172B, de 28 de Dezembro de 1926; 2.210, de 28 de Novembro de 1927 e 2226-A de 19 de Dezembro de 1927 e consolida as disposições vigentes relativas ao serviço policial do Estado e ás atribuições das respectivas autoridades. ALESP, São Paulo.

${ }^{385}$ Força Pública do Estado de São Paulo. Boletim Geral, São Paulo, n. 8, p. 51, 31 mai. 1928.

${ }^{386}$ É pouco provável que tenha havido concurso anterior a 1928 para o provimento dos cargos de oficiais músicos dentro da Força Pública. No entanto, ao que tudo indica, a evolução dessa carreira se deu com Antão, que, em 1895, fora declarado alferes sem passar por uma banca examinadora, seguindo em suas promoções até o posto de capitão até sua exoneração a pedido em 1926. Lorena, que fora indicado por Antão (e faleceu em 1926), e Chiarelli, que veio do Corpo de Bombeiros e em 1928 era o capitão inspetor de música (cargo máximo dentro da hierarquia da Banda), também não possuem registros de aprovação em concurso dessa natureza.
} 
concedida, o conteúdo programático para as provas, a serem realizadas nos dias 9, 10 e 11 de julho de 1928, foi o seguinte:

a) Harmonizar para piano ou quarteto vocal um Baixo Cifrado e um Canto Dado (contraponto);

b) Instrumentação de um trecho para banda; e

c) Direção prática de uma partitura para banda, escolhida dentre as apresentadas pelo candidato. ${ }^{387}$

Conforme se pode observar pelo programa de exames, o foco do concurso estava essencialmente na condução do grupo, como demonstra a prova prática de regência (item c), além da capacidade que o candidato deveria demonstrar para lidar com a harmonia (item a) e a arte da instrumentação (item b), provando seu conhecimento de todos os instrumentos que compunham a Banda de Música, incluídos seus registros, combinações, timbres e tessituras (organologia). O programa, portanto, exigia conhecimentos que somente poderiam ser adquiridos por meio de um estudo sistemático de música, preferencialmente oferecido pelos conservatórios. ${ }^{388}$ Ao final do concurso, a banca examinadora considerou aprovados os candidatos cuja média aritmética atingira nota superior a 6,0 (inclusive). Por esse critério, o documento $^{389}$ trazia que os candidatos José Machado ( $1^{\circ}$ sargento) e Miguel de Marca ( $2^{\circ}$ sargento) haviam sido aprovados com uma média de 8,3 e 7,5, respectivamente. ${ }^{390}$

Narciso Juliano também fora promovido após o restabelecimento da normalidade em agosto de 1924, ao que tudo indica, sem concurso. Iniciava-se em 1928, portanto, a regulamentação legal do acesso ao Quadro de Oficiais Músicos da Força Pública.

${ }^{387}$ Boletim Geral, Força Pública do Estado de São Paulo. São Paulo, n. 25, p. 200, 20 jun. 1928.

${ }^{388}$ C f. Boletim Geral, Força Pública do Estado de São Paulo. São Paulo, n. 29, p. 241-242, 25 jun. 1928. A banca examinadora composta para a realização do concurso contou com a presença dos Professores João Gomes de Araújo, Francisco Casabona e teve como fiscal Samuel Archanjo dos Santos, todos titulares do Conservatório Dramático e Musical de São Paulo. A lista de concorrentes foi composta pelas seguintes Praças: $1^{\circ}$ sargentos músicos de classe distinta Matheus Caramico e José Machado; $2^{\circ}$ sargentos músicos de $1^{\mathrm{a}}$ classe Antônio Barbarisco, Miguel de Marca, Benedicto Adriano de Oliveira e Manoel Lopergolo.

${ }^{389}$ Boletim Geral, Força Pública do Estado de São Paulo. São Paulo, n. 44, p. 377, 12. jul. 1928. Ata Final contendo o resultado para o provimento do cargo de $2^{\circ}$ tenente auxiliar da banda de música da Força Pública do Estado de São Paulo. Anexo ao Ofício no 76 de 11 de julho de 1926. Do Secretário do Conservatório Dramático e Musical de São Paulo ao Sr. Comandante Geral da Força Pública do Estado de São Paulo. Assinado por: Professor Samuel Archanjo dos Santos.

$390 \mathrm{O} 1^{\circ}$ sargento Matheus Caramico fora desclassificado e desligado do concurso por desistência. Foram considerados reprovados os $2^{\circ}$ s sargentos Antônio Barbarisco (média 3,1), Manoel Lupergolo (média 3,0) e Benedicto Adriano de Oliveira (média 2,1). 
Em 17 de julho de 1928, por Decreto do Presidente do Estado, José Machado foi promovido ao cargo de $2^{\circ}$ tenente auxiliar da Banda de Música da Força Pública. ${ }^{391}$ Miguel de Marca, também aprovado, ainda deveria aguardar o surgimento de uma vaga para sua promoção. Como não havia expectativa para de Marca ser promovido na Força Pública, foi movimentado a título de adido ${ }^{392}$ para a Guarda Civil de São Paulo, onde organizou a banda daquela instituição, retornando para a Força Pública em 1931, na condição de sargentoajudante, quando então foi designado para chefiar uma Seção de Banda como mestre.

Aquele ano de 1928 foi profícuo para a Banda da Força, que tomou os espaços da cidade, revivendo os tempos anteriores à década de 1920, apresentando concertos no Jardim da Luz, Jardim do Palácio do Governo, esplanada do Teatro Municipal (Parque do Anhangabaú), Conservatório Dramático Musical, Parque do Trianon, Teatro São Pedro, Teatro Sagrado Coração de Jesus, Parque da Água Branca e, é claro, as ruas da cidade em desfiles. Em agosto, Antão - nesse momento, reformado e professor de piano e matérias teóricas na escola de música da Cruz Azul de São Paulo - entregou doações de algumas composições suas para a Banda de Música, talvez na tentativa de manter viva sua memória dentro da corporação onde serviu boa parte de sua existência. Uma dessas obras foi a Marcha 22 de Maio, escrita naquele ano pelo maestro. ${ }^{393}$

Os concertos e apresentações da Banda de Música continuaram em um bom ritmo, conforme se pode constatar nos dados da Tabela 12, que traz informações sobre o repertório daquele ano. Foram coletados 31 programas de concertos musicais publicados nos Boletins Gerais da Força Pública, além de apresentações internas da Banda e outras apresentações públicas. Um dos pontos altos das comemorações cívicas voltou a ser o Sete de Setembro. Encerradas as paradas do Quinze de novembro nos Prados da Mooca em 1927, o Ipiranga passou a ser o local de quase todas as festas.

\footnotetext{
391 Boletim Geral, Força Pública do Estado de São Paulo. São Paulo, n. 49, p. 416, 19 jul. 1928.

392 Adição ou adido é a situação funcional na administração militar em que um militar pertencente a uma Organização Militar é movimentado por tempo determinado para outra a título de "empréstimo". A adição pode ocorrer mesmo sem a decorrência de vaga para acomodá-lo.

393 A Marcha 22 de Maio, de autoria de Joaquim Antão Fernandes, não foi localizada no Arquivo Geral do Corpo Musical da Polícia Militar do Estado de São Paulo. A única composição de sua autoria encontrada no acervo do Corpo Musical foi Aurora da Liberdade, uma abertura que celebra a abolição da escravatura, cuja datação é da década de 1930.
} 


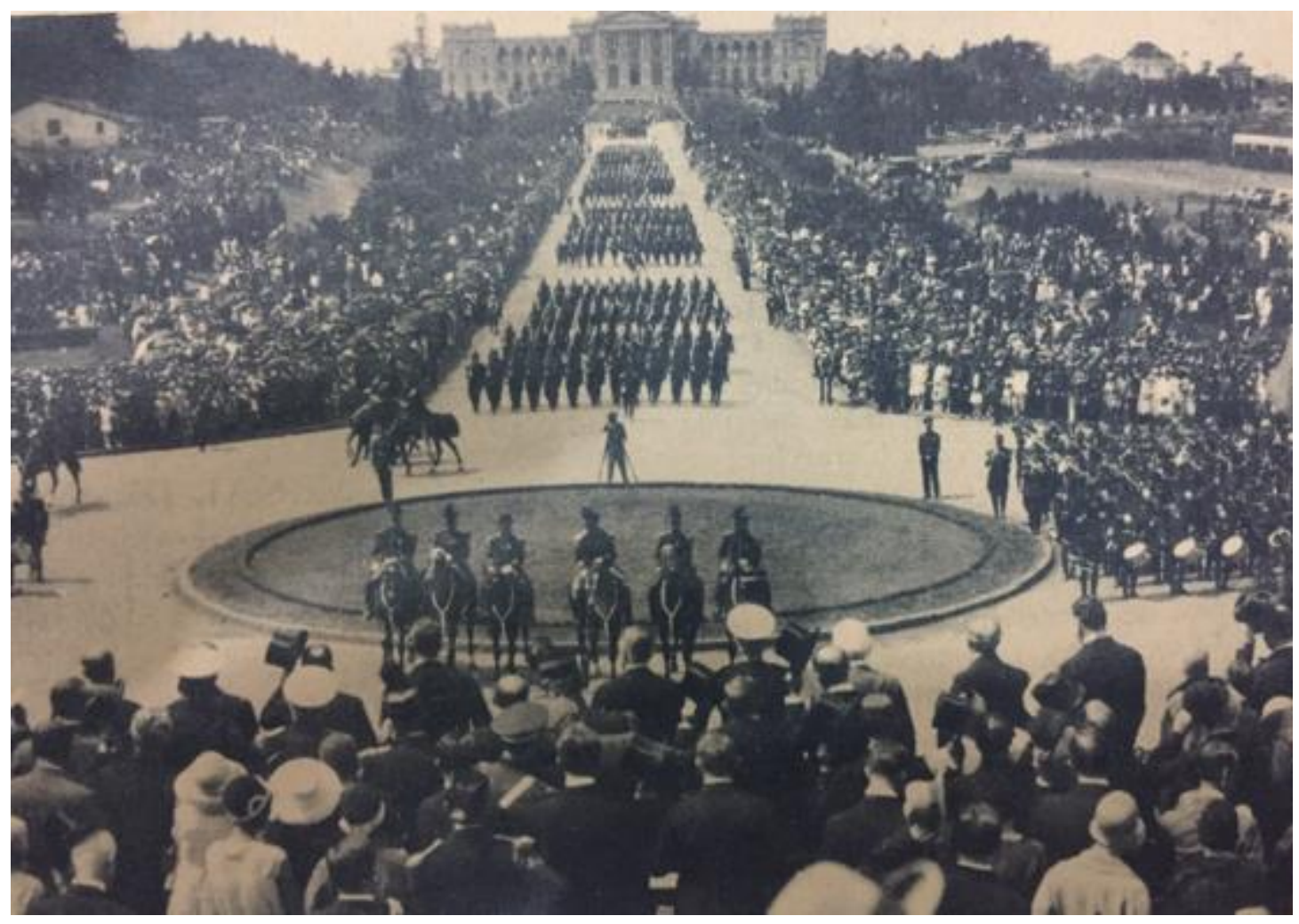

Figura 22

Banda de Música da Força Pública do Estado de São Paulo. Desfile cívico militar de 7 de setembro de 1929. Colina do Ipiranga - São Paulo.

Fonte: ANDRADE, Euclides; DA CÂMARA, Hely F. A Força Pública de São Paulo: esboço histórico. São Paulo: Sociedade Impressora Paulista, 1931. p. 42. Autoria desconhecida.

No documento anterior, é possível visualizar, no plano central superior, o prédio do Museu Paulista da Universidade de São Paulo. Ao centro, as tropas da Força Pública descendo a colina do Ipiranga em desfile, formadas por companhias. Ao centro e no plano inferior da fotografia, o Estado-Maior combinado, montado a cavalo, prestando continências às autoridades dispostas na escadaria do monumento à Independência. Ainda no plano inferior, vê-se à direita a Banda de Música da Força Pública completa; à frente e à esquerda, um soldado portando tambor, membro da banda de cornetas e tambores. No canto superior esquerdo, observando a multidão e a festa em seu silêncio simbólico, está a Casa do Grito.

Em $1^{\text {o }}$ de outubro de 1929, foi publicado o Decreto n. 4638, que, após 28 anos, reajustava os valores recolhidos ao Tesouro do Estado pela prestação de serviços musicais, na seguinte conformidade:

No Município da Capital:

Banda completa: 
Primeira hora - mínimo: $400 \$ 000$

Horas seguintes - mínimo: $200 \$ 000$

Cada Seção:

Primeira hora - mínimo: $200 \$ 000$

Horas seguintes - mínimo: $100 \$ 000$

Para fora do Município da Capital:

Banda completa:

Mínimo por dia: 2:000\$000

Cada Seção:

Mínimo por dia: 1:000\$000.

À semelhança do anterior e dos posteriores que viriam, o Decreto alertava ainda que as despesas de transporte e hospedagem, incluindo-se as de alimentação durante a viagem, correriam por conta do contratante. ${ }^{394}$ Vale lembrar que o primeiro decreto que fixou uma política de cobrança e arrecadação para a Banda de Música da Força fora expedido em 1901 e que as taxas a serem aplicadas a partir de 1929 continham um reajuste de $100 \%$ nos valores. Dessa forma, tornaram-se, no mínimo, condizentes com os preços aplicados pelas outras corporações na cidade, valorizando de forma direta a Banda e suas prestações de serviços. A aplicação desse tipo de cobrança, no entanto, era descartada para órgãos públicos das três esferas e dos três poderes, bem como para autarquias.

\section{Presto: as turbulências políticas interna e externa dos 1930}

A década de 1930 significou um período de novas mudanças para a Banda de Música e sua instituição mantenedora. Dentro do cenário de instabilidade política que se instaurou com a revolução de outubro, a Força Pública de São Paulo entrou em um processo de desmantelamento nos primeiros anos da era Vargas, que acabaria repercutindo em todos os seus segmentos, incluindo a Banda. É preciso esclarecer que outros fatores também contribuíram para o "recolhimento" não apenas da corporação musical da Força, mas de quase todas as demais bandas na cidade de São Paulo, como veremos.

A partir de dezembro de 1929, foram suspensos os concertos realizados semanalmente no Largo do Palácio pela Banda da Força Pública, em razão das obras para a

\footnotetext{
${ }^{394}$ Decreto n. 4638 de 1 out. 1929. ALESP, São Paulo, 1929.
} 
construção do viaduto da rua Boa Vista, ${ }^{395}$ e essa foi apenas uma das medidas adotadas pelo comando geral em relação a seu conjunto musical a partir da década de 1930. Em abril, um novo documento comunicava que, por ordem do Diretor Geral da Higiene Municipal, haviam sido suspensos, até segunda ordem, os concertos executados no Jardim da Luz, na esplanada do Teatro Municipal e no Parque do Anhangabaú. ${ }^{396}$ Dessa forma, três dos locais públicos mais frequentados pelas bandas silenciavam, produzindo-se um certo tom lúgubre e destoante dos últimos anos. As fontes revelam que, após abril e até o final de 1930, não houve mais registros de concertos e apresentações nos espaços públicos de costume. Em contrapartida, em setembro de 1930, ocorreu o primeiro contrato entre a Banda da Força Pública de São Paulo e a Rádio Educadora Paulista, tendo em vista a realização de um concerto nos estúdios da emissora. ${ }^{397}$ Dessa forma, a Banda abria um novo ambiente de apresentação com a possibilidade de alcançar um público infinitamente maior do que aquele das praças públicas.

Diante das instabilidades políticas, sociais e urbanas, a Banda de Música sobreviveu, ainda que precariamente. Em suas memórias, Antão relata que em dezembro de 1930 foi procurado por um músico da Banda com bilhete assinado por seu amigo, o General Miguel Costa, reintegrado e comandante agora da Força Pública. Ele convocava o maestro para uma reunião para discutir e decidir por seu retorno como regente da Banda da Força Pública, 398 que aceitou imediatamente. ${ }^{399}$ Embora tenha criado algumas tensões, na percepção de Antão o convite de reintegração era justo, uma vez que visava a corrigir sua reforma praticamente compulsória, ocorrida durante a Revolução de 1924. O fato é que, com o retorno de Antão e a fixação de apenas uma vaga de capitão na Banda de Música, Salvador Chiarelli (capitão) e Narciso Juliano ( $1^{\mathrm{o}}$ tenente) foram reformados (aposentados) compulsoriamente, sob alegação de que ambos já haviam completado 25 anos de serviços prestados à Força Pública. Como decorrência, em junho de 1931 novo decreto era publicado ${ }^{400}$ fixando nova estrutura e vagas na Banda. Na nova formação o grupo passou a ter 67 figuras, incluindo os oficiais e

\footnotetext{
${ }^{395}$ Boletim Geral, Força Pública do Estado de São Paulo. São Paulo, no 284, p. 2485, 7 dez. 1929.

${ }^{396}$ Boletim Geral, Força Pública do Estado de São Paulo. São Paulo, n. 81, p. 734-735, 10 abr. 1930. Ofício n. 605 de 08 abr. 1930. Do Cmt. do $1^{\circ}$ B/I ao Comandante Geral da Força Pública.

${ }^{397}$ Boletim Geral, Força Pública do Estado de São Paulo. São Paulo, n. 210, p. 1874, 20 set. 1930.

${ }^{398}$ FERNANDES, Joaquim Antão. Minha autobiografia. São Paulo: s/editora, 1943. p. 18. Mimeografado.

${ }^{399}$ Boletim Geral, Força Pública do Estado de São Paulo. Apresentação de Officiaes. In: Boletim da Inspecção Geral, São Paulo, n. 36, p 2, 31 dez. 1930.

${ }^{400}$ Decreto n. 5.079 de 27 jun. 1931. Reorganiza e fixa a Força Publica do Estado de São Paulo para o segundo semestre de 1931. ALESP, São Paulo, 1931.
} 
estabeleceu novas regras e hierarquias internas. O Decreto anexou ainda a Banda ao $1^{\circ}$ Batalhão de Caçadores (antigo Batalhão de Infantaria).

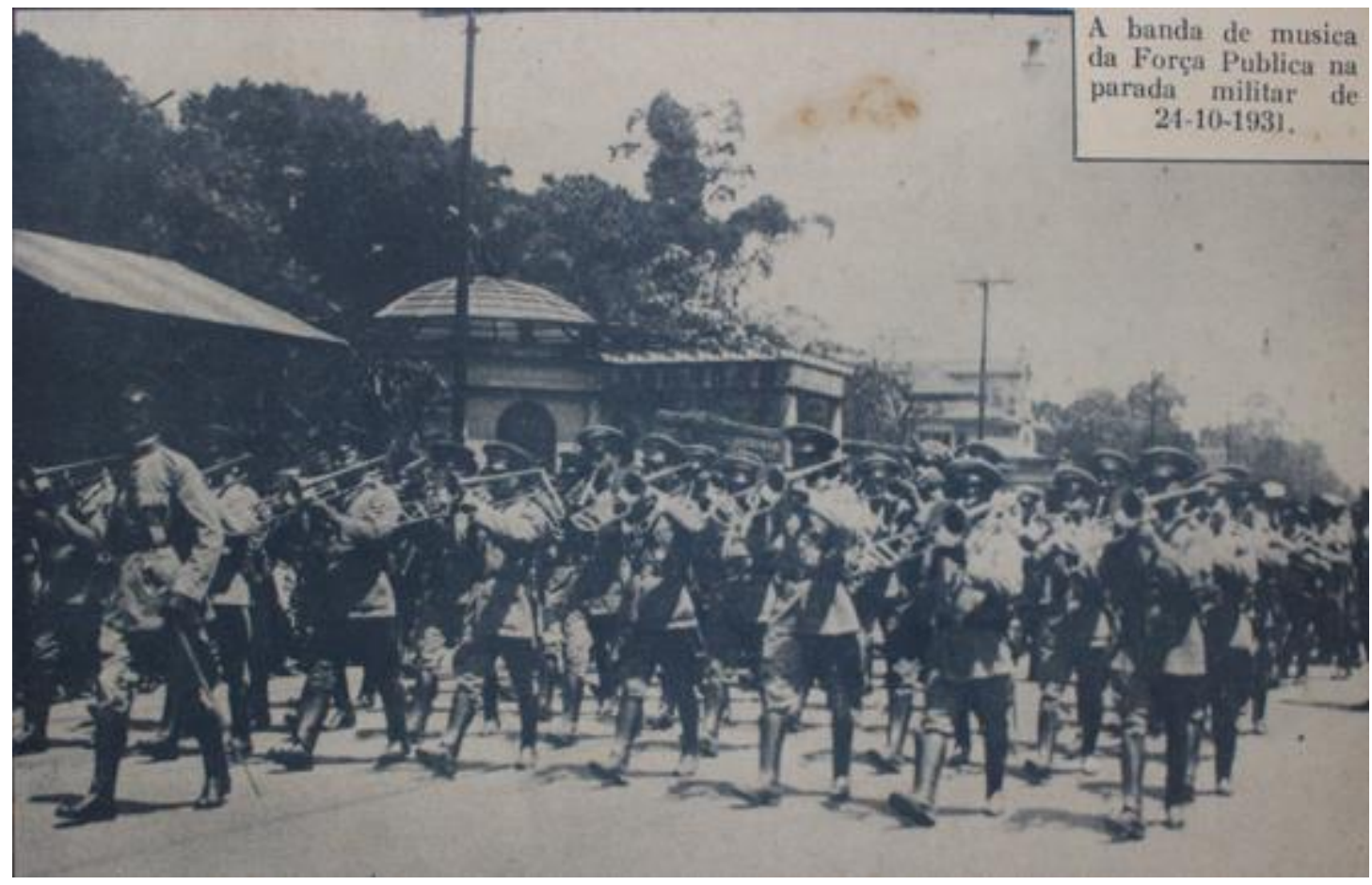

Figura 23

Banda de música da Força Pública do Estado de São Paulo na parada militar de 24 out. 1931. Local: Avenida Paulista. Autoria desconhecida.

Fonte: ANDRADE, Euclides; DA CÂMARA, Hely F. A Força Pública de São Paulo. Esboço histórico. São Paulo: Sociedade Impressora Paulista, 1931. p. 182.

Essa relação da Banda com os novos tempos políticos pode ser identificada na imagem acima. Nela a Banda desfila no primeiro aniversário da revolução de outubro na Avenida Paulista com 64 figuras, formada em oito colunas com linhas de oito músicos, regida pelo maestro Antão, que marcha à frente. Por ocasião do evento, o General Miguel Costa emitiu nota elogiando a participação da banda na comemoração. ${ }^{401}$

Embora os registros da Força Pública atestem a presença de uma Banda de Música (dividida em duas Seções), encontramos nas fontes a partir de 1931, novamente, a presença de mais conjuntos (fanfarras), tanto no $1^{\circ}$ como no $2^{\circ}$ Batalhões de Caçadores, além da Jazz Band, a cumprir apresentações musicais. Em 13 de novembro como parte das comemorações

${ }^{401}$ Boletim Geral, Força Pública do Estado de São Paulo. São Paulo, n. 254, p. 2.408-2.413, 30 out. 1931. 
da República, houve música nas seguintes localidades a partir das 17h: $1^{\text {a }}$ Seção de Banda na Praça da República, 2 ${ }^{\text {a }}$ Seção de Banda no Parque D. Pedro II, a Banda do $1^{\circ}$ Batalhão de Caçadores Paulista no Largo do Rosário (Penha), a Banda do $2^{\circ}$ Batalhão de Caçadores Paulista no Largo de S. José do Belém e a Jazz Band da Cruz Azul na Praça Buenos Aires. ${ }^{402}$ Era talvez a tentativa de uma retomada daqueles espaços públicos que, no entanto, se tornariam inviáveis a partir de maio do ano seguinte. No campo técnico, o maior ganho do ano foi, sem dúvida, o ingresso de Antônio Romeu, clarinetista da futura Orquestra Sinfônica Municipal que, formado pelo Conservatório Dramático e Musical de São Paulo, chegaria ao comando do conjunto musical da Força em 1939 (apenas 8 anos após seu ingresso) e nele permanecendo como maestro até 1953.

Como se pode verificar, após a revolução de 1930 e as turbulências criadas por ela em São Paulo, a proximidade e a amizade de Joaquim Antão e o Secretário de Segurança Pública e comandante geral da Força foram importantíssimas para garantir a sobrevivência do grupo dentro do conturbado cenário que se descortinou nessa instituição.

\section{Do Presto ao Largo: 1932 em diante}

Ao longo deste capítulo, descrevemos de forma linear como a Banda de Música da Força Pública foi aos poucos se adaptando à estrutura cultural da cidade, desde o início da segunda metade do século XIX. Ao chegarmos aos anos que sucedem o movimento de 1932, continuaremos nossa análise, detendo-nos, porém, no ano de 1934, marcado pelo início do Governo Constitucional Varguista e a gestão de Armando Sales de Oliveira como Interventor Federal nomeado para o estado de São Paulo. Tal recorte foi pautado em duas razões: a primeira delas foi a ascensão de José Machado ao comando e regência da Banda de Música, ascensão que imprimiu novo ritmo e nova gestão ao grupo. A segunda foi a sedimentação do ambiente da radiofonia e seus estúdios.

O início de 1932 trouxe uma novidade interessante para a Banda de Música. Foi dado um largo passo no sentido da conquista de uma liberdade reivindicada há tempos pelos mestres anteriores. ${ }^{403} \mathrm{O}$ poder de decidir onde, quando, como e o quanto tocar estava bem mais próximo do maestro; e essa trilha de autonomia culminou com a promoção de Joaquim

\footnotetext{
402 Boletim Geral, Força Pública do Estado de São Paulo. São Paulo, n. 265, p. 2.515, 13 nov. 1931.

${ }^{403}$ Boletim Geral, Força Pública do Estado de São Paulo. São Paulo, n. 2, p. 7-8, 2 jan. 1932.
} 
Antão ao posto de major. ${ }^{404}$ Tal promoção permitiu ao maestro o acesso a uma série de informações e a reuniões do alto comando, o que gerou maior autonomia em suas decisões e poder de opinar e convencer em tomadas de decisão pelo comando. Em resumo, o maestro e a Banda ganharam o direito a uma voz que, até aquele momento, não se podia ouvir dentro do Estado-Maior da Força Pública.

Como a instituição mantenedora crescera e a Banda não acompanhara o mesmo ritmo em 28 de janeiro de 1932, foi expedida ordem ao inspetor para que fracionasse o corpo musical da Força não mais em duas Seções, como tinha ocorrido desde a primeira década do século, mas novamente em três. ${ }^{405}$ A medida visava dar maior possibilidade de atendimento aos serviços internos da instituição, uma vez que, com mais um grupo musical, as demandas por atendimento poderiam ser aumentadas. Com 65 músicos no total, sem contar os dois oficiais (um major e um $2^{\circ}$ tenente), cada grupo passava a possuir cerca de 21 componentes. ${ }^{406}$

Em março de 1932, foi realizado um concurso para cabos na Banda de Música do qual resultaram seis novos músicos. ${ }^{407}$ Antônio Bento da Cunha, trompetista, era um deles. Poucos anos depois, haveria outra reestruturação, em que se abririam vagas para acomodar mais cabos e os soldados. Ambos os concursos foram passos importantes para a arregimentação de músicos, uma vez que a Força Pública não possuía concurso aberto para o provimento dos cargos de sargento músico, dificultando, sobremaneira, o preenchimento das vagas.

Em 23 de maio, as tensões políticas e os conflitos armados no estado deflagraram mudanças em todos os setores da Força Pública, incluindo a troca do comandante geral, tendo assumido a função o coronel Júlio Marcondes Salgado. Do ponto de vista político interno, o novo comandante nutria ainda certa simpatia por Antão e pela Banda de Música, o que garantiu uma curta sobrevida com a mesma estrutura. No entanto, logo as coisas mudaram,

\footnotetext{
${ }^{404}$ Boletim Geral, Força Pública do Estado de São Paulo. São Paulo, n. 9, p. 67, 11 jan. 1932.

${ }^{405}$ Boletim Geral, Força Pública do Estado de São Paulo. São Paulo, p. 194, 28 jan. 1932.

${ }^{406}$ Cf. Boletim Geral, Força Pública do Estado de São Paulo. São Paulo, n. 43, p. 404, 24 fev.1932. Com a divisão dos músicos em três grupos, foi preciso designar-se os chefes de seção para cada uma das bandas e, por proposta do inspetor, foram nomeados para exercer essas funções de mestres o sargento ajudante Miguel de Marca (que retornava da Banda da Guarda Civil) para a $2^{\mathrm{a}}$ seção, e o sargento ajudante Antônio Romeu para a $3^{\mathrm{a}}$ seção. A $1^{\mathrm{a}}$ Seção de Banda permaneceu sob os cuidados do $2^{\circ}$ tenente José Machado auxiliar do inspetor e, quando o grupo todo se reunia, a regência era de Antão.

${ }^{407}$ Boletim Geral, Força Pública do Estado de São Paulo. São Paulo, nº 63, p. 611, São Paulo, 18 mar. 1932.
} 
uma vez que Marcondes Salgado morreria em um teste de munição para morteiros em Santo Amaro em 22 de julho. ${ }^{408}$ O sucessor de Salgado foi o coronel Herculano de Carvalho Silva, que, possuindo uma visão diferente da de seu antecessor, decretou, em meio ao conflito, a adoção de algumas medidas que se contrapunham francamente àquelas determinadas por Miguel Costa (agora em prisão domiciliar) quase dois anos antes. Entre as medidas estava a reforma compulsória de alguns oficiais que haviam sido nomeados pelo General exSecretário de Segurança e, entre estes, constava o nome do major Joaquim Antão Fernandes. ${ }^{409}$ Assumiu interinamente em seu lugar o $2^{\circ}$ tenente músico José Machado, aprovado no concurso de $1928 .{ }^{410}$ Dessa forma, a figura do maestro Antão deixava definitivamente a cena após mais de 40 anos ligados à história desse conjunto musical.

Embora a Banda se encontrasse naquele momento em meio aos desacertos do movimento bélico e em parcas condições de apresentações, já que parte de seus músicos havia sido distribuída para o apoio das tropas paulistas, a reforma de Antão representou o fim de um breve tempo de crescimento iniciado com seu retorno no final de 1930. Mais que isso, representou a perda de importantes conquistas consolidadas durante seu segundo período de gestão na companhia de Miguel Costa como comandante geral e Secretário de Segurança Pública. A nomeação do maestro da Banda ao posto de major e toda a autonomia que viera com ele, a estruturação piramidal e o plano de carreira das praças músicos, a possibilidade de agregar os cabos e soldados mesmo sem a oferta oficial de vagas foram conquistas que, a partir de sua saída, dificilmente um oficial no posto de $2^{\circ}$ tenente conseguiria manter..$^{411}$

Durante o período que vai da reforma de Antão até o mês de novembro daquele ano de 1932, a Banda limitou-se a apoiar as tropas em todos os sentidos possíveis. Fragmentada, não conseguiu cumprir também compromissos firmados, mediante contratos, de realizar concertos nos estúdios da Rádio Cruzeiro do Sul em razão do estado das coisas. Em 21 de outubro, o Presidente da Cruz Azul de São Paulo, em ofício endereçado ao comandante geral da Força, informava que, na assembleia geral realizada naquela data, fora decidida a

\footnotetext{
${ }^{408}$ Boletim Geral, Força Pública do Estado de São Paulo. São Paulo, nº 167, p. 1.543, 22 jul. 1932.

${ }^{409}$ Boletim Geral, Força Pública do Estado de São Paulo. São Paulo, n. 168, p. 1546, 23 jul. 1932.

${ }^{410}$ Boletim Geral, Força Pública do Estado de São Paulo. São Paulo, n. 170, p. 1.559, 26 jul. 1932.

${ }^{411}$ As bases para esse argumento não estão fundamentadas na competência musical e sim na hierarquia militar. Embora o $2^{\circ}$ tenente José Machado fosse um maestro tecnicamente competente para o exercício da regência e do comando do conjunto musical da Força Pública, seu posto como Oficial subalterno limitava-o muito em relação ao de Antão, que era major, tornando aquele mero cumpridor de ordens do comando geral e portador de uma autonomia que quase não lhe servia para nada dentro daquele universo institucional.
} 
dissolução do Jazz Band. Alegava que o grupo acarretava prejuízos aos cofres daquela instituição diante da crise econômica pela qual esta passava, apesar dos músicos pertencerem à Força Pública. ${ }^{412}$.

Passado o período de maior tensão e dificuldades, a Banda recebeu ordem em novembro de 1932 para o reinício de suas retretas públicas às quintas-feiras e domingos em lugares variáveis que seriam determinados pelo comando da Força. A ordem continha ainda a autorização para o maestro José Machado requisitar as demais bandas de corneteiros e tambores de outras unidades quando o repertório assim o exigisse, sem necessidade de dirigir-se ao comando geral. ${ }^{413}$ Após um longo período de distanciamento involuntário reiniciava-se a aproximação da Banda com o público paulistano e, em 4 de dezembro, as retretas no Jardim da Luz, voltavam a acontecer. No programa daquele 4 de dezembro houve Wagner, Pancardi, Bizet, Mascagni e outros eruditos, repertório que demonstrava que a Banda manteve sua excelência técnica. ${ }^{414}$ Um dia após essa retreta, o estado desincumbia a Banda de Música de participar, como colaboradora nas receitas da Caixa Beneficente da Força Pública. ${ }^{415}$ Dessa forma, encerrava-se também mais um ciclo: A Banda não mais contribuía para arrecadação do sistema previdenciário da instituição.

O último grande evento do qual a Banda participou naquele ano de 1932 foi o acompanhamento do cortejo do corpo de Santos Dumont. Ela tocou em 18 de dezembro na Avenida Rangel Pestana, ${ }^{416}$ a Marcha Fúnebre de Chopin. ${ }^{417}$

O ano de 1933 registrou várias mudanças e novas leis alteraram a estrutura da Banda. Na dinâmica da legislação que de certa forma tumultuou sua vida interna, um aspecto de valorização profissional foi a proibição do emprego dos músicos em outras funções dentro do quartel. Cabe ressaltar também que a partir deste período todo esse efetivo de 119 homens não permaneceu em São Paulo por muito tempo, uma vez que já havia três Bandas Regimentais no interior do estado - Santos, Itapetininga e uma nova em Ribeirão Preto, que

\footnotetext{
412 Boletim Geral, Força Pública do Estado de São Paulo. São Paulo, n. 251, p. 2.089, 27 out. 1932. Ofício n. 934 do Ten. Cel. Presidente da Cruz Azul ao sr. Cmt. Geral da Força Pública do Estado de São Paulo.

413 Boletim Geral, Força Pública do Estado de São Paulo. São Paulo, n. 260, p. 2.193, 8 nov. 1932.

414 Boletim Geral, Força Pública do Estado de São Paulo. São Paulo, n. 15, p. 123, 3 dez. 1932.

${ }^{415}$ Decreto no 5.751 de 5 dez. 1932. Modifica o regulamento da Caixa Beneficente da Força Pública do Estado. ALESP, São Paulo: 1932.

${ }^{416}$ SANTOS Dumont. Exposição do corpo do genial inventor: homenagens a serem prestadas nesta capital e no Rio. O Estado de São Paulo, São Paulo, p. 3, 16 dez. 1932.

${ }^{417}$ Boletim Geral, Força Pública do Estado de São Paulo. São Paulo, n. 26, p. 224-225, 17 dez. 1932.
} 
seria criada seis meses depois em abril de 1934 -, para onde José Machado passou a transferir músicos a título de auxílio. Devidamente regulamentada e reconhecida, em dezembro novamente outro decreto, que fixava a Força Pública para 1934, elevava ainda mais o efetivo da Banda de Música para 120 homens com a adição de mais um sargento ajudante. ${ }^{418}$

Conforme a orientação do comando geral desde novembro de 1932, a rotina das apresentações em locais públicos perdurou pelo ano todo de 1933, mas o grande evento da Força Pública, que, como sempre, contou com a participação da Banda de Música, foi um concerto no Teatro Municipal de São Paulo. ${ }^{419}$ Não mais tocando ao lado de fora, a Banda que, naquela comemoração dos 44 anos da República, ocupara seu palco, era maior e melhor, mais madura e bem mais preparada que aquela do desfile de 1890 quando, percorrendo as ruas do centro da cidade, puxara as tropas comandadas pelo coronel Lisboa, sendo regida pelo sargento-mestre Bernardo Jorge da Costa para as comemorações do primeiro aniversário da República. Após quase 80 anos, a Banda, embora não soubesse, estava em meio a um caminho de transformações entre a instituição e a comunidade.

\footnotetext{
${ }^{418}$ Decreto n. 6.240 de 27 dez. 1933. Reorganiza e Fixa a Força Pública do Estado para o ano de 1934. ALESP, São Paulo, 1933.

${ }^{419}$ DELlA MONICA, Laura. História da Banda de Música da Polícia Militar do Estado de São Paulo. São Paulo: Edanee, 1975. p. 76.
} 


\section{Considerações finais}

Esta pesquisa se inscreve na perspectiva da história cultural da cidade de São Paulo, em especial seu ambiente musical. Neste contexto amplo, as bandas de música foram o objeto central da investigação. O elevado número de bandas identificado pela pesquisa foi surpreendente e relevou bem como elas fizeram parte de modo ativo deste cenário. Como explicado, então, esse fenômeno cultural tornou-se a questão central que conduziu a pesquisa. A trajetória da Banda da Fora Pública foi o principal fio condutor da narrativa explicativa.

As bandas desempenharam múltiplos papéis no início do século XX. De certo modo, foram espaços para a preservação, difusão e mistura das várias culturas presentes na cidade. O repertório divulgado por elas revelou de maneira dispare essa dinâmica. Ele refletia os gostos do momento ou as preferências impostas por tensões políticas, sociais e econômicas. As fontes, por exemplo, apresentaram dados que indicam uma tendência de mudança entre o que se tocava no final do século XIX (valsas, polcas, maxixes, mazurcas) e aquele tocado na virada do XX (árias de ópera, trechos de sinfonias, movimentos de concertos e aberturas). Como ficou evidente, neste período houve uma transição de repertório de peças curtas para o de concerto. Nesse sentido, os dados coletados dos programas da Banda de Música da Força Pública do Estado de São Paulo e as apresentações das bandas italianas, ilustraram muito bem essa mudança para a música de concerto. Desdobramento deste processo foi o fato de que esse tipo de repertório saiu dos teatros para a praça pública, dando acesso à população e popularizando aspectos da música de concerto.

Muitas vezes elas serviram também como uma espécie de escola formativa de instrumentistas e como espaço de profissionalização e sobrevivência do músico de origem mais pobre. Aprendizes e iniciantes eram admitidos nas corporações musicais e aos poucos ganhavam capacitação para o exercício da música. Embora o músico de banda trabalhasse muito, ganhava pouco e seu grande desafio era conquistar seu meio de trabalho: o instrumento musical. Havia a necessidade desse profissional se desdobrar, tocando em vários grupos para poder minimamente sobreviver e sustentar a família.

Neste contexto diversificado, se notabilizou a trajetória da Banda de Música da Força

Pública do Estado de São Paulo, que desde o final do século XIX se estabilizou como conjunto musical profissional. Um dos principais protagonistas deste longo processo de 
consolidação da banda militar como um conjunto de destaque no panorama musical paulistano, foi o maestro Joaquim Antão Fernandes. Figura enérgica, ativa e polêmica, soube associar as questões artísticas com as políticas internas ao corpo militar e as externas, o que permitiu vida institucional longa para a banda. Neste sentido, como em um jogo de palavras, a referência a antiga banda dos "Permanentes" - da Guarda Municipal Permanente sobrevive até hoje como a Banda de Música da Polícia Militar de São Paulo.

Como todo panorama musical do período, a partir do final da década de 1920, mas sobretudo durante os anos 1930, a relação das bandas com o cotidiano musical da cidade começou a mudar substancialmente, em razão do desenvolvimento e expansão das indústrias fonográfica e radiofônica. Apesar da relativa presença de algumas delas nestes novos meios de produção e divulgação, como revelou a investigação, com as gravações em 78 rotações da Força Pública, Ettore Fieramosca, Giuseppe Verdi e Veríssimo Glória, a maior parte das bandas civis praticamente desapareceu e a Banda da Força Pública, especialmente, passou a ter suas funções culturais e musicais muito reduzidas, restritas ao ambiente militar. Foi esta dinâmica de transformações da cultura musical paulistana tendo como fio condutor a Banda da Força Pública que esta dissertação procurou captar e compreender. Trata-se ainda de uma pesquisa em aberto, diante da raridade do tema, da rarefação das fontes e da renitência do objeto. Deste modo, espera-se que essa dissertação permita novos trabalhos relacionados a esse rico universo sonoro e musical paulistano. 


\section{FONTES}

\section{Arquivo da Câmara Municipal de São Paulo}

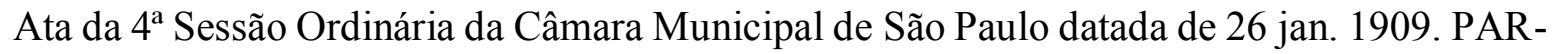
CJ 11 e CF 09.

Lei $n^{\circ} 552$ de 28 out. 1901. Orça a receita e fixa a despesa do município de São Paulo para o ano de 1902.

\section{Assembleia Legislativa do Estado de São Paulo}

Decreto n. 348 de 6 abr. 1896. Dá regulamento à Força Pública do Estado, ALESP, São Paulo, 1896.

Decreto n. 437 de 20 março de 1897. Dá Regulamento à Força Policial do Estado. ALESP, São Paulo, 1897.

Decreto n. 874 de 9 fev. 1901. Dá instrucções à banda de musica da Brigada Policial do Estado. ALESP, São Paulo, 1901.

Decreto n. 1.714 de 18 mar. 1909. Dá regulamento para os divertimentos públicos nos termos do artigo 28 da lei $\mathrm{n}^{\circ} 1.103$, de 26 de novembro de 1907 e mais disposições em vigor. ALESP. São Paulo, 1909.

Decreto n. 2.228 de 17 abr. 1912. Manda observar a tabella de continências da Força Pública. ALESP, São Paulo, 1912.

Decreto n. 4405-A de 17 de abril de 1928. Dá regulamento às leis nºs.2.034 de 30 de dezembro de 1924; 2.172-B de 28 de dezembro de 1926; 2.210 de 28 de novembro de 1927 e 2226-A de 19 de dezembro de 1927 e consolida as disposições vigentes relativas ao serviço policial do Estado e às atribuições das respectivas autoridades. ALESP, São Paulo, 1928.

Decreto n. 4638 de 1 out. 1929. ALESP, São Paulo, 1929.

Decreto n. 5.079 de 27 jun. 1931. Reorganiza e fixa a Força Publica do Estado de São Paulo para o segundo semestre de 1931. ALESP, São Paulo, 1931.

Decreto $\mathrm{n}^{\mathrm{o}} 5.751$ de 5 dez. 1932. Modifica o regulamento da Caixa Beneficente da Força Pública do Estado. ALESP, São Paulo, 1932.

Decreto no 5.781 de 28 dez. 1931. Fixa o efetivo da Força Publica para o ano de 1933. ALESP, São Paulo, 1931. 
Decreto n. 6.153 de 13 nov. 1933. Reorganiza a banda de musica da Força Publica do Estado. ALESP, São Paulo, 1933.

Decreto n. 6.240 de 27 dez. 1933. Reorganiza e Fixa a Força Pública do Estado para o ano de 1934. ALESP, São Paulo, 1933.

Decreto-Lei 6885 de 29 dez. 1934. Reorganiza a Guarda Civil de SÃO PAULO ALESP, São Paulo, 1934.

Lei n. 19 de 27 fev. 1844. ALESP, São Paulo, 1844.

Lei n. 24 de 7 abr. 1857. ALESP, São Paulo,1857.

Lei n. 64 de 10 abr. 1870. ALESP, São Paulo, 1870.

Lei n. 42 de 31 mar. 1882. ALESP, São Paulo, 1882.

Lei n. 33 de 30 mar. 1883. ALESP, São Paulo, 1883.

Lei n. 54 de $01^{\circ}$ abr. 1884. ALESP, São Paulo, 1884.

Lei n. 67 de 26 mar. 1885. ALESP, São Paulo, 1885.

Lei n. 78 de 3 mai. 1886. ALESP, São Paulo, 1886.

Lei n. 29 de 24 mar.1887. ALESP, São Paulo, 1887.

Lei n. 27 de 10 mar. 1888. ALESP, São Paulo, 1888.

Lei n 17 de 14 nov. 1891. Fixa a Força Pública do Estado para o anno de 1892. ALESP, São Paulo, 1891.

Lei n. 97A de 21 set. 1892. Fixa a Força Pública do Estado para o anno de 1893. ALESP, São Paulo, 1892.

Lei n. 97B de 21 set. 1892. Organiza a Força Pública do Estado para o anno de 1893. ALESP, São Paulo, 1892.

Lei n. 186 de 22 de agosto de 1893. Fixa a Força Pública do Estado para o anno de 1894. ALESP, São Paulo, 1893

Lei n. 273-A de 23 de junho de 1894. Fixa a Força Pública do Estado para o exercício de 1895. ALESP, São Paulo, 1894.

Lei n. 354 de 28 de agosto de 1895. Fixa a Força Pública do Estado para o exercício de 1896. ALESP, São Paulo, 1895.

Lei 491 de 29 dez. 1896. Reorganiza a Força Pública do Estado. ALESP, São Paulo, 1896.

Lei n. 652 de 16 de agosto de 1899. Fixa a Força Pública para o anno de 1900. ALESP, São Paulo, 1889. 
Lei n. 653 de 16 ago. 1899. Reorganiza a Força Pública do Estado. ALESP, São Paulo, 1899. Lei 722 de 16 out. 1900. Fixa a Força Pública do Estado para o ano de 1901. ALESP, São Paulo, 1900.

Lei n. 851 de 28 out. 1902. Fixa a Força Policial para o anno de 1903. ALESP, São Paulo, 1902.

Lei $\mathrm{n}^{\circ} 628$ de 7 fev. 1903. Autoriza o augmento de 3:000\$000 na verba <Jardins etc> da Lei n. 552 de 28 de outubro de 1901. ALESP, São Paulo, 1903.

Lei n. 958 de 28 set. 1905. Reorganiza a Força Pública do Estado e dá outras instrucções. ALESP, São Paulo, 1905.

Lei n. 1092-A de 16 out. 1907. Fixa a Força Pública do Estado, para o exercício de 1908. ALESP, São Paulo, 1907.

Lei n. 1175 de 29 out. 1909. Fixa a Força Pública para o exercício de 1910. ALESP, São Paulo, 1909.

Lei n. 1.343 de 17 dez. 1912. Fixa a Força Pública para o exercício de 1913. ALESP. São Paulo, 1913.

Lei n. 1395-A de 17 dez. 1913. Fixa a Força Pública para o exercício de 1914. ALESP. São Paulo, 1913.

Lei n. 1.444-A de 24 dez. 1914. Fixa a Força Pública para o exercício de 1915. ALESP. São Paulo, 1914.

Lei n. 1.454 de 29 dez. 1914. Estabelece diversas disposições de caráter permanente com relação à Força Pública do Estado. ALESP. São Paulo, 1914.

Lei n. 1.483-A de 7 dez. 1915. Fixa a Força Pública para o exercício de 1916. ALESP. São Paulo, 1915.

Lei n. 1.498 de 30 dez. 1915. Altera as disposições das Leis sobre a Caixa Beneficente da Força Pública. ALESP. São Paulo, 1915.

Lei n. 1.511-A de 2 dez.1916. Fixa a Força Pública para o exercício de 1917. ALESP. São Paulo, 1916.

Lei n. 1.558 de 20 out. 1917. Modifica a organização da Força Pública do Estado de São Paulo. ALESP. São Paulo, 1917.

Decreto s/n. de 30 out. 1923. Dispõe sobre o plano de uniformes da Força Pública do Estado de São Paulo a que se refere o decreto desta data. ALESP. São Paulo, 1923. 
Lei n. 2.141 de 22 out. 1926. Crêa a Guarda Civil da Capital. ALESP, São Paulo, 1926. Lei n ${ }^{\circ}$ 2.206-A de 19 nov. 1927. Reorganiza a Força Pública do Estado de São Paulo. ALESP, São Paulo, 1927.

\section{Câmara Federal}

Decreto n. 21.111 de $01^{\circ}$ mar. 1932. Aprova o regulamento para a execução dos serviços de radiocomunicação no território nacional. Rio de Janeiro, 1932.

Lei $\mathrm{n}^{\circ} 5.700$ de $01^{\circ}$ set. 1971. Dispõe sobre a forma e apresentação dos símbolos nacionais e dá outras providências. Brasília, 1971.

\section{Discografia}

Coleção José Ramos Tinhorão Instituto Moreira Salles - RJ, Fonogramas:

ANTÃo FERNANDES, Maestro Joaquim. Banda de Música da Força Policial de São Paulo. Amor saudoso, São Paulo: Odeon, 1907-1912. 1 disco sonoro (2’55”) 78 rpm, 27 cm. Selo n.108430.

ANTÃo FERNANDES, Maestro Joaquim. Banda de Música da Força Policial de São Paulo. Ao clarão da lua, São Paulo: Odeon, 1907-1912. 1 disco sonoro (3’06”) 78 rpm, 27 cm. Selo n. 108411 .

BECUCCI, Ernesto. Banda Ettore Fieramosca. Bella chilena, São Paulo: Odeon, 1912-1915. 1 disco sonoro (4’16”) 78 rpm, 27 cm. Selo n.120658.

DUARTE, Felipe. Banda de Música da Força Policial de São Paulo. A vassourinha, São Paulo: Odeon, 1912-1915. 1 disco sonoro (4’18”) 78 rpm, 27 cm. Selo n.120668.

DUTRA, Felipe. Banda Veríssimo Glória. O conscrito, São Paulo: Odeon, 1912-1915. 1 disco sonoro (3'48”) 78 rpm, $27 \mathrm{~cm}$. Selo n.120645.

GLÓRIA, Felipe. Banda Veríssimo Glória. Os Vianas, São Paulo: Odeon, 1912-1915. 1 disco sonoro (3'47”) $78 \mathrm{rpm}, 27 \mathrm{~cm}$. Selo n.120639.

GLÓRIA N. Banda Ettore Fieramosca. Noventa e dois. São Paulo: Odeon, 1912-1915. 1 disco sonoro (3’35”) $78 \mathrm{rpm}, 27 \mathrm{~cm}$. Selo n. 120651.

GREVISTA. Banda de Música da Força Policial de São Paulo. O maxixe. São Paulo: Odeon, 1912-1915. 1 disco sonoro (3'20”) 78 rpm, 27 cm. Selo n. 120663. 
LEHAR, Franz. Banda de Música da Força Policial de São Paulo. Viúva alegre. São Paulo: Odeon, 1907-1912. 1 disco sonoro (2'53”) 78 rpm, 27 cm. Selo n.108410.

OSWALDO, Maestro. Banda de Música da Força Policial de São Paulo. Valsa lenta do Maestro Oswaldo. São Paulo: Odeon, 1907-1912. 1 disco sonoro (2’54”) 78 rpm, 27 cm. Selo n. 108421.

RURIZ. Banda Veríssimo Glória. Didinha. São Paulo: Odeon, 1912-1915. 1 disco sonoro (3’36”) 78 rpm, 27 cm. Selo n. 120647.

S/Autor. Banda de Música da Força Policial de São Paulo. Atraído por uma flor. São Paulo: Odeon, 1907-1912. 1 disco sonoro (2’49”) 78 rpm, 27 cm. Selo n. 108424.

S/Autor. Banda de Música da Força Policial de São Paulo. Atraído por uma flor. São Paulo: Odeon, 1912-1915. 1 disco sonoro (2’49”) 78 rpm, 27 cm. Selo n. 120669.

S/Autor. Banda de Música da Força Policial de São Paulo. Coalhada. São Paulo: Odeon, 1907-1912. 1 disco sonoro (2’58’) 78 rpm, 27 cm. Selo n. 108412.

S/Autor. Banda de Música da Força Policial de São Paulo. Japonês. São Paulo: Odeon, 19071912. 1 disco sonoro (3’10”) 78 rpm, 27 cm. Selo n. 108426.

S/Autor. Banda de Música da Força Policial de São Paulo. Manuelita. São Paulo: Odeon, 1907-1912. 1 disco sonoro (3'04”) 78 rpm, 27 cm. Selo n. 108433.

S/Autor. Banda de Música da Força Policial de São Paulo. Rio Branco, São Paulo: Odeon, 1907-1912. 1 disco sonoro (2’53’) 78 rpm, 27 cm. Selo n. 108436.

S/Autor. Banda de Música da Força Policial de São Paulo. Titita. São Paulo: Odeon, 19071912. 1 disco sonoro (2'51”) 78 rpm, 27 cm. Selo n. 108431.

S/Autor. Banda de Música da Força Policial de São Paulo. Tudinha. São Paulo: Odeon, 19071912. 1 disco sonoro (3'18’) 78 rpm, 27 cm. Selo n. 108429.

S/Autor. Banda Ettore Fieramosca. Desfolhando rosas São Paulo: Odeon, 1907-1912. 1 disco sonoro (3'05”) 78 rpm, 27 cm. Selo n. 108456.

S/Autor. Banda Ettore Fieramosca. Los toreros. São Paulo: Odeon, 1907-1912. 1 disco sonoro (2’42”) 78 rpm, 27 cm. Selo n. 108444.

S/Autor. Banda Ettore Fieramosca. Paulistinha. São Paulo: Odeon, 1907-1912. 1 disco sonoro (3'00”) 78 rpm, 27 cm. Selo n. 108455.

S/Autor. Banda Ettore Fieramosca. Quanto dói uma saudade. São Paulo: Odeon, 1912-1915. 1 disco sonoro (3'52”) 78 rpm, 27 cm. Selo n. 120652. 
S/Autor. Banda Ettore Fieramosca. Rédea solta. São Paulo: Odeon, 1912-1915. 1 disco sonoro (3'37’) 78 rpm, 27 cm. Selo n. 120655.

S/Autor. Banda Ettore Fieramosca. Segredo. São Paulo: Odeon, 1912-1915. 1 disco sonoro (3’38’) 78 rpm, 27 cm. Selo n. 120661.

S/Autor. Banda Ettore Fieramosca. Sonho perigoso. São Paulo: Odeon, 1907-1912. 1 disco sonoro (3'14") 78 rpm, 27 cm. Selo n. 108463.

S/Autor. Banda Veríssimo Glória. Valadino. São Paulo: Odeon, 1912-1915. 1 disco sonoro (3’43”) 78 rpm, 27 cm. Selo n. 120649.

Coleção 78 rpm de Miguel Braghioni, Porto Ferreira, Fonogramas:

FORLIN, Luiz. Banda de Música Giuseppe Verdi de São Paulo. Brasil unido. São Paulo: Arte-Fone, 1932. 1 disco sonoro (2’49”) 78 rpm, 10”. Selo n. 4107.

N. N. Banda de Música Giuseppe Verdi de São Paulo. Trianeiras. São Paulo: Arte-Fone, 1932. 1 disco sonoro (3’03”) 78 rpm, 10”. Selo n. 4107.

Coleção 78 rpm de Miguel Ângelo de Azevedo - Nirez - Fortaleza, CE.

Coleção da Fundação Joaquim Nabuco, Base de dados discos 78 rpm.

\section{Museu da Polícia Militar do Estado de São Paulo}

Boletim Geral, Força Pública do Estado de São Paulo. São Paulo, n. 1, p. 3, 1 jan. 1925.

Boletim Geral, Força Pública do Estado de São Paulo. São Paulo, n. 93, p. 827. 27 abr. 1925.

Boletim Geral, Força Pública do Estado de São Paulo. São Paulo, n. 131, p. 1.118. 13 jun. 1925.

Boletim Geral, Força Pública do Estado de São Paulo. São Paulo, n. 39, p. 308, 18 fev. 1925.

Boletim Geral, Força Pública do Estado de São Paulo. São Paulo, n. 181, p. 357, 18 ago. 1925.

Boletim Geral, Força Pública do Estado de São Paulo. São Paulo, n. 227, p. 768, 16 out. 1925.

Boletim Geral, Força Pública do Estado de São Paulo. São Paulo, n. 50, p. 463, 8 mar. 1926. 
Boletim Geral, Força Pública do Estado de São Paulo. São Paulo, n. 115, p. 1000-1002, 29 mai. 1926.

Boletim Geral, Força Pública do Estado de São Paulo. São Paulo, n. 1, p. 3, 3 jan. 1927.

Boletim Geral, Força Pública do Estado de São Paulo. São Paulo, n. 145, p. 1.237, 8 jul. 1927.

Boletim Geral, Força Pública do Estado de São Paulo. São Paulo, n. 44, p. 361, 23 fev.1928. Boletim Geral, Força Pública do Estado de São Paulo. São Paulo, n. 8, p. 51, 31 mai. 1928.

Boletim Geral, Força Pública do Estado de São Paulo. São Paulo, n. 25, p. 200, 20 jun. 1928. Boletim Geral, Força Pública do Estado de São Paulo. São Paulo, n. 29, p. 241-242, 25 jun. 1928.

Boletim Geral, Força Pública do Estado de São Paulo. São Paulo, n. 44, p. 377, 12. jul. 1928. Boletim Geral, Força Pública do Estado de São Paulo. São Paulo, n. 49, p. 416, 19 jul. 1928. Boletim Geral, Força Pública do Estado de São Paulo. São Paulo, n. 164, p. 1497, 16 jul. 1929.

Boletim Geral, Força Pública do Estado de São Paulo. São Paulo, no 284, p. 2485, 7 dez. 1929.

Boletim Geral, Força Pública do Estado de São Paulo. São Paulo, n. 81, p. 734-735, 10 abr. 1930.

Boletim Geral, Força Pública do Estado de São Paulo. São Paulo, n. 210, p. 1874, 20 set. 1930.

Boletim Geral, Força Pública do Estado de São Paulo. São Paulo, n. 234, p. 2098, 17 out. 1930.

Boletim Geral, Força Pública do Estado de São Paulo. Boletim Revolucionário no 1 . In: Força Pública do Estado de São Paulo. São Paulo, n. 251, p. 2.245-2.248, 4 nov. 1930.

Boletim Geral, Força Pública do Estado de São Paulo. Boletim Revolucionário no 1. In: Força Pública do Estado de São Paulo. São Paulo, n. 251, p. 2257-2258. 4 nov. 1930.

Boletim Geral, Força Pública do Estado de São Paulo. Apresentação de Officiaes. In: Boletim da Inspecção Geral, São Paulo, n. 36, p 2, 31 dez. 1930.

Boletim Geral, Força Pública do Estado de São Paulo. São Paulo, n. 5, p. 56, 7 jan. 1931.

Boletim Geral, Força Pública do Estado de São Paulo. Classificação de Official. In: Boletim da Inspecção Geral, São Paulo, n. 4, p. 89, 9 jan. 1931. 
Boletim Geral, Força Pública do Estado de São Paulo. São Paulo, n. 254, p. 2.408-2.413, 30 out. 1931.

Boletim Geral, Força Pública do Estado de São Paulo. São Paulo, n. 265, p. 2.515, 13 nov. 1931.

Boletim Geral, Força Pública do Estado de São Paulo. São Paulo, n. 2, p. 7-8, 2 jan. 1932.

Boletim Geral, Força Pública do Estado de São Paulo. São Paulo, n. 9, p. 67, 11 jan. 1932.

Boletim Geral, Força Pública do Estado de São Paulo. São Paulo, n. 25, p. 194, 28 jan. 1932.

Boletim Geral, Força Pública do Estado de São Paulo. São Paulo, n. 43, p. 404, 24 fev.1932.

Boletim Geral, Força Pública do Estado de São Paulo. São Paulo, no 63, p. 611, São Paulo, 18 mar. 1932.

Boletim Geral, Força Pública do Estado de São Paulo. São Paulo, n. 167, p. 1.543, 22 jul. 1932.

Boletim Geral, Força Pública do Estado de São Paulo. São Paulo, n. 168, p. 1546, 23 jul. 1932.

Boletim Geral, Força Pública do Estado de São Paulo. São Paulo, n. 170, p. 1.559, 26 jul. 1932.

Boletim Geral, Força Pública do Estado de São Paulo. São Paulo, n. 173, p.1.577, 25 de julho de 1932.

Boletim Geral, Força Pública do Estado de São Paulo. São Paulo, n. 251, p. 2.089, 27 out. 1932.

Boletim Geral, Força Pública do Estado de São Paulo. São Paulo, n. 260, p. 2.193, 8 nov. 1932.

Boletim Geral, Força Pública do Estado de São Paulo. São Paulo, n. 15, p. 123, 3 dez. 1932.

Boletim Geral, Força Pública do Estado de São Paulo. São Paulo, n. 26, p. 224-225, 17 dez. 1932.

Ordem do dia do Primeiro Batalhão de Infantaria, Força Pública do Estado de São Paulo. São Paulo, n. 4, 4 jan. 1918.

\section{MANUSCRITOS}

FERNANDES, Joaquim Antão. Autobiografia. São Paulo: Sem editora, 1943. Mimeografado. 


\section{PERIÓDICOS}

Correio Paulistano, 1857, 1988, 1890, 1891, 1892, 1902, e 1903, 1904, 1922 e 1936.

O Estado de São Paulo, 1889, 1890, 1891, 1892, 1902, 1903, 1906, 1910, 1912, 1915, 1989.

\section{OUTROS JORNAIS}

Almanach histórico e literário de São Paulo, Prefeitura Municipal. p. 321. São Paulo, 01 jan. 1895.

\section{CRONISTAS E MEMORIALISTAS}

AMERICANO, Jorge. São Paulo naquele tempo: 1895-1915. 2. ed. São Paulo: Carrenho Editorial, Narrativa Um, Carbono 14, 2004.

AMERICANO, Jorge. São Paulo nesse tempo (1915-1935). São Paulo: Melhoramentos, 1962

BANANÉRE, Juó (pseudônimo Alexandre Ribeiro Marcondes Machado). La divina encrenca, Falco Masucci, São Paulo, 1966.

BRUNO, Ernani Silva. História e tradições da cidade de São Paulo. Rio de Janeiro: José Olympio Editora, 1954. v. III.

CAPRI, Roberto (org.). São Paulo - a capital artística na comemoração do centenário 1822-1922, São Paulo, 1922.

FREITAS, Afonso Antônio de. Tradições e reminiscências paulistanas. São Paulo: Governo do Estado, 1978;

GAENSLY, Guilherme. São Paulo 1900. São Paulo: Livraria Kosmos Editora, 1988.

GATTAI, Zélia. Anarquistas graças a Deus. São Paulo: Companhia das Letras, 2009.

MACHADO, Antônio Alcântara. Brás, Bexiga e Barra Funda, IMESP/DAESP, São Paulo, 1982.

MARTINS, Antônio Egydio. São Paulo antigo: 1554 a 1910. São Paulo: Paz e Terra. 2003. MILANO, Miguel. Os fantasmas da São Paulo antiga. São Paulo: Ed. UNESP, 2012. PENTEADO, Jacob. Belenzinho 1910 (retrato de uma época), Martins, São Paulo, 1962. PINTO, Alfredo Moreira. A cidade de São Paulo em 1900: impressões de viagem. Rio de Janeiro: Imprensa Nacional, 1900. 
RAFFARD, Henrique. Alguns dias na Paulicéia. São Paulo: Academia Paulista de Letras, 1977.

\section{BIBLIOGRAFIA GERAL}

ALMEIDA, Aloísio de. Folclore da banda de música. Revista do Arquivo Público Municipal, v. CLXXVI, jan.-mar. 1969.

ANCHIETA TORRES, José de. Origem da banda de música. Militia, São Paulo, n. 28, mai.jun. 1952.

ANDRADE, Euclides; DA CÂMARA, Hely F. A Força Pública de São Paulo: esboço histórico. São Paulo: Sociedade Impressora Paulista, 1931.

ANDRADE, MÁRIO DE. Dicionário Musical Brasileiro. Oneyda Alvarenga, et al. (Eds.) Belo Horizonte, Brasília, São Paulo: Itatiaia, Min. da Cultura, IEB, EDUSP, 1989.

ARRUDA, Luiz Eduardo Pesce de. Polícia Militar: uma crônica. A Força Policial, São

Paulo, n. 13, p. 31-84, jan.-mar. 1997.

ARRUDA, Luiz Eduardo Pesce de. José Barbosa de Brito. A Força Policial, São Paulo, p. 3-5, abr/mai/jun 2006

ASSUMPÇÃO, Eduardo. Evolução técnico-cultural, determinação e desenvolvimento do PM. 1984. Monografia (Conclusão do Curso Superior de Polícia-I/84). Polícia Militar do Estado de São Paulo, São Paulo.

AZEVEDO, Elizabeth R. O teatro em São Paulo 1554-1954. In: PORTA, Paula (Org.). História da cidade de São Paulo. São Paulo: Paz e Terra. 2004. vol. 1.

AZEVEDO, Militão Augusto de; Militão Augusto de Azevedo. Textos de Rubens Fernandes Jr, Heloisa Barbuy, Fraya Frehse: comentário das imagens Henrique Siqueira; versão para o inglês Juliet Attwater. v. 1, 2 e 3. São Paulo: Cosac Naify, 2012.

BENJAMIM, Walter. A obra de arte na era de sua reprodutibilidade técnica. Porto Alegre: Zouk, 2012.

BESSA, Virgínia de Almeida. A cena musical paulistana: teatro musicado e canção popular na cidade de São Paulo (1914-1934). 2012. Tese (Doutorado) - Faculdade de Filosofia, Letras e Ciências Humanas, Universidade de São Paulo, São Paulo. 
BINDER, Fernando Pereira. Bandas Militares no Brasil: difusão e organização entre 1808 e 1889 volumes I a III. 2006. Dissertação (Mestrado) - Instituto de Artes da Universidade Estadual Paulista, São Paulo.

BOMFIM, Camila Carrazcosa. A música orquestral, a metrópole e o mercado de trabalho: o declínio das orquestras profissionais subsidiadas por organismos públicos na região metropolitana de São Paulo de 2000 a 2016. 2017. Tese (Doutorado) - Instituto de Artes da Universidade Estadual Paulista, São Paulo.

BOSI, Ecléa. Lembrança de D. Brites. In: BOSI, Ecléa. Memória e sociedade: lembrança de velhos. São Paulo: Companhia das Letras, 2003.

CANCLINI, Nestor Garcia. Culturas híbridas: estratégias para entrar y salir de la modernidade. Ciudad de Mexico: Grijalbo,1989.

CAPRI, Roberto (Org.). São Paulo - a capital artística na comemoração do centenário 1822-1922, São Paulo: s/editora, 1922.

DaMATTA, Roberto. Carnavais, paradas e procissões. In: Carnavais, malandros e heróis: para uma sociologia do dilema brasileiro. 6. ed. Rio de Janeiro: Rocco, 1997.

DALLARI, Dalmo de Abreu. O pequeno exército paulista. São Paulo: Perspectiva, 1977.

DELlA MONICA, Laura. História da Banda de Música da Polícia Militar do Estado de São Paulo. 2. ed. São Paulo: Edanee, 1975.

EDO, Elizabeth Ribeiro. Conservatório Dramático e Musical de São Paulo: pioneiro e centenário. Revista Histórica, São Paulo, n. 16, p. 1-6, out. 2006.

FAUSTO, Boris. Negócios e ócios: histórias da imigração. São Paulo: Companhia das Letras, 1997.

FERNANDES, Heloisa. A Força Pública dos Estado de São Paulo. In: FAUSTO, Boris; HOLANDA, Sérgio Buarque (Coord.). História geral da civilização brasileira. Tomo III, v. 2, São Paulo: Difel, 1977.

FERNANDES, Heloisa Rodrigues. Política e segurança. São Paulo: Alfa-ômega, 1974.

FERRAZ, Cel. Arrisom de Souza. As paradas da Força Pública nos prados da Moóca. Revista do Arquivo Público Municipal, São Paulo, v. CLXII, p. 383-390, jan.-mar. 1959.

FONSECA, Denise Sella. Uma "colcha de retalhos": a música em cena em São Paulo entre o final do século XIX e início do XX. 2014. Dissertação (Mestrado) - Faculdade de Filosofia, Letras e Ciências Humanas da Universidade de São Paulo, São Paulo. 
FRANCESCHI, Humberto M. A Casa Edison e seu tempo. Rio de Janeiro: Sarapuí, 2002.

FREITAS Jr. Afonso de. Origem do Viaduto do Chá. Revista do Arquivo Público Municipal, São Paulo, v. XXV, p. 175-184, jul. 1936.

FREITAS, Sonia Maria de. “Falam os imigrantes... Memória e diversidade cultural em São Paulo”. 2001. Tese (Doutorado em História) - Faculdade de Filosofia, Letras e Ciências Humanas, Universidade de São Paulo, São Paulo.

FREHSE, Fraya. Ô da Rua! O transeunte e o advento da modernidade em São Paulo. São Paulo: EdUSP, 2011.

GONÇALVES, Camila Koshiba. Vitrola paulistana pelos olhos e ouvidos de um basbaqueandarilho In: MORAES, José Geraldo Vinci de; SALIBA, Elias Thomé (Org.). História e música no Brasil. São Paulo: Alameda Casa Editorial. 2010.

GONÇALVES, Camila Koshiba. Música em 78 rotações. Discos a todos os preços na São Paulo dos anos 30. São Paulo: Alameda, 2013.

GONÇALVES, Janice. Música na cidade de São Paulo (1850-1900): o circuito da partitura. 1995. Dissertação (Mestrado) - Faculdade de Filosofia, Ciências Humanas e Letras, Universidade de São Paulo.

GONZALES, Juliana Pérez. A indústria fonográfica e a música caipira gravada. 2018. Tese (Doutorado) - Faculdade de Filosofia, Letras e Ciências Humanas, Universidade de São Paulo, São Paulo.

HARDMAN, Francisco Foot. Nem Pátria nem patrão. Vida operária e cultura anarquista no Brasil. 2. ed. São Paulo: Brasiliense, 1984.

HARDMAN, Francisco Foot. Lyra da Lapa: acorde imperfeito menor. Campinas, UNICAMP. In: Coleção Remate de Males No 5.1984.

HOBSBAWM, Eric. A história social do jazz. Rio de Janeiro: Paz e Terra, 1990.

IKEDA, Alberto T. Apontamentos históricos sobre o jazz no Brasil: primeiros momentos. Revista de Comunicação e Artes (ECA-USP), Ano 10, v.13, p.111-24, 1984.

KENNEY, William Howland. Rercorded music in American life: the phonograph and popular memory, 1890-1945. New York: Oxford University Press, 2002.

LE GOFF, Jacques. Documento/Monumento. In: LE GOFF, Jacques. Memória-História, Campinas: Ed. Universidade de Campinas, 1990. 
LIMA, Solange Ferraz. Pátio do Colégio, Largo do Palácio. In: Anais do Museu Paulista, São Paulo, v. 6-7, n. 1, p. 61-82, 1999.

LOVE, Joseph. A Locomotiva: São Paulo na Federação Brasileira. 1889-1937. Rio de Janeiro: Paz e Terra, 1982.

MAGALHÃES, Paulo Ribeiro. A fundação do Teatro Municipal. Revista do Arquivo Público Municipal, São Paulo, v. 16, p. 127-131, ago. 1935.

MAISONNEUVE, Sophie. L'invention $d u$ disque, 1877-1949. Paris: Archives Contemporaines Editions, 2009.

MARTINS, José de Souza. Sociologia da fotografia e da imagem. São Paulo: Contexto, 2008.

MELLONE, Dirceu Jair. Corpo musical. Arte e profissão. Monografia apresentada ao Curso de Aperfeiçoamento de Oficiais-I/86 (CAO), São Paulo: PMESP, 1986.

MORAES, José Geraldo Vinci de. Arranjos e timbres da música em São Paulo. In: PORTA, Paula (Org.). História da cidade de São Paulo. São Paulo: Paz e Terra, 2004. vol. 1.

MORAES, José Geraldo Vinci de. Cidade e cultura urbana na Primeira República. São Paulo: Atual editora, 1994.

MORAES, José Geraldo Vinci de. Metrópole em sinfonia: história, cultura e música popular na São Paulo dos anos 30. São Paulo: Estação Liberdade, 2000.

MORAES, José Geraldo Vinci de. Sonoridades paulistanas: final do século XIX ao início do século XX. Rio de Janeiro: Bienal, 1997.

MORAES, José Geraldo Vinci de; FONSECA, Denise Sella. A música em cena na Belle Epoque paulistana. Revista IEB, São Paulo, n. 54, set.-mar. 2012. p. 107-138.

MORAES, José Geraldo Vinci de; SALIBA. Elias Thomé (Org.). História e música no Brasil. São Paulo: Alameda Casa Editorial, 2010.

MORAES, Waldyr Rodrigues de. Em busca do passado. A Força Policial, São Paulo, n. 23, p. 75, jul.-ago.-set. 1999.

MORSE, Richard. Formação histórica de São Paulo. São Paulo: Difusão Europeia do Livro. 1970.

NAPOLITANO, Marcos. "Fontes audiovisuais. A História depois do papel”, In: PINSKY, Carla Bassanezi. (Org.) Fontes Históricas 3 ${ }^{\mathrm{a}}$ ed. p. 235-290. São Paulo: Contexto, 2014. 
NAXARA, Márcia Regina Capelari. Estrangeiro em sua Própria Terra-Representações do Brasileiro 1870/1920. São Paulo: Annalumbre. 1998.

ODALIA, Nilo e CALDEIRA, J. R. C. História do Estado de São Paulo - a formação da unidade paulista vol. 2 República. São Paulo: Editora UNESP. 2010.

PAIVA, Odair da Cruz. Histórias da (I)migração: imigrantes e migrantes em São Paulo entre o final do século XIX e o início do século XXI. São Paulo: Arquivo Público do Estado, 2003.

PAOLI, M. C.; DUARTE, A. São Paulo no plural: espaço público e redes de sociabilidade. In: PORTA, Paula (Org.). História da Cidade de São Paulo: a cidade na primeira metade do século XX 1890-1954. v. 3. São Paulo: Paz e Terra, 2004. p. 53-98.

PÉREZ GONZALES, Juliana. A indústria fonográfica e a música caipira gravada: uma experiência paulista (1878-1930). 2018. Tese (Doutorado) - Faculdade de Filosofia Letras e Ciências Humanas da Universidade de São Paulo, São Paulo.

PINHEIRO, Paulo Sérgio. O proletariado industrial na primeira república. In: FAUSTO, Bóris; HOLANDA, Sérgio Buarque (Coord.). História Geral da Civilização Brasileira. Tomo III, v. 2, São Paulo: 1977. p. 135-178.

PINTO, Maria Inêz Machado Borges. Cotidiano e sobrevivência. São Paulo: EdUSP, 1994.

QUEIROZ, Suely Robles Reis de. Política e poder público na cidade de São Paulo: 18891954. In: PORTA, Paula (Org.). História da cidade de São Paulo: a cidade na primeira metade do século XX-1890-1954. São Paulo: Paz e Terra, 2004. v. 3.

PRADO Jr, Caio; A cidade de São Paulo Geografia e história. São Paulo: Brasiliense, 1983. RAGO, Margareth. A invenção do cotidiano na metrópole: sociabilidade e lazer em São Paul, 1900-1950. In: PORTA, Paula. (Org.). História da Cidade de São Paulo: a cidade na primeira metade do século XX 1890-1954. São Paulo: Paz e Terra, 2004. v. 3. p.387-435.

RANGER, Terence O.; HOBSBAWM, Eric. J. A invenção das tradições. São Paulo: Paz e Terra, 2012.

ROLNIK, Raquel. A cidade e a Lei. Legislação, política urbana e territórios na cidade de São Paulo. São Paulo: Studio Nobel, 1997.

SAES, Flávio. São Paulo republicana: vida econômica: In: PORTA, Paula (Org.). História da cidade de São Paulo: a cidade na primeira metade do século XX - 1890-1954. São Paulo: Paz e Terra, 2004. 
SALIBA, Elias Thomé. Histórias, memórias, tramas e dramas da identidade paulista. In: PORTA, Paula (Org.). História da Cidade de São Paulo: a cidade na primeira metade do século XX 1890-1954. São Paulo: Paz e Terra, 2004. v. 3, p. 555-587.

SANT’ANA. Nuto. O Jardim da Luz. Revista do Arquivo Público Municipal. São Paulo, vol. LXI, p. 43-52, set.-out. 1939.

SANTOS, Alcino; BARBALHO, Gracio; SEVERIANO, Jairo; AZEVEDO, Miguel Ângelo de (Nirez). Discografia brasileira 78 rpm - 1904 a 1964. 5 v. Rio de Janeiro: FUNARTE, 1982.

SANTOS, Carlos José Ferreira dos. Nem tudo era italiano. São Paulo e pobreza (1890-1915), São Paulo: ANNABLUME, 1998.

SANTOS, João Alberto de Menezes dos. O clarinete: sistemas de chaves França/Alemanha. 2004. Dissertação (Mestrado) - Faculdade de Ciências Sociais e Humanas, Universidade Nova Lisboa, Lisboa.

SCHWARCZ, Lilia Moritz. As barbas do Imperador: D. Pedro II, um monarca nos trópicos. 2. ed. São Paulo: Companhia das Letras. 2010.

SEGAWA, Hugo. Ao amor do público: jardins do Brasil. São Paulo: Studio Nobel, 1996.

SEVCENKO, Nicolau. Orfeu extático na metrópole: São Paulo sociedade e cultura nos frementes anos 20. São Paulo: Companhia das Letras, 2003. p. 31.

SILVA, Juliana Soares da Costa. Práticas musicais, comunidade, localidade e velhice: um estudo etnográfico sobre a Corporação musical operária da Lapa.2018. Dissertação (Mestrado) Instituto de Artes, Universidade Estadual de Campinas, Campinas.

SINGER, Paul. Economia Política da Urbanização. São Paulo: Contexto, 1998. SIRIANI, Silvia Cristina Lambert. Uma São Paulo alemã: vida quotidiana dos imigrantes germânicos na região da capital (1827-1889). São Paulo: Imprensa Oficial do Estado, 2003. SOUZA, Maria Adélia Aparecida de; "Metrópole e paisagem: caminhos e descaminhos da urbanização". In: Paula Porta (Org.), História da Cidade de São Paulo. A cidade na primeira metade do século XX 1890 1954. São Paulo: Paz e Terra, 2004. v.3, p.517-553.

STERNE, Jonathan. The audible past: cultural origins of sound reproduction. Durham, N.C; London: Duke University Press, 2003. 
TELHADA, Paulo Adriano Lucinda Lopes. Quartel da Luz-mansão da ROTA: histórias do Batalhão Tobias de Aguiar. São Paulo: Just Editora, 2011.

TINHORÃO, José Ramos. Os sons que vêm da rua. 2. ed. São Paulo: Editora 34, 2005.

TONI, Flávia Camargo. Uma Orquestra Sinfônica para São Paulo. Revista Música.

Departamento de Música da Escola de Comunicação e Artes da Universidade de São Paulo, São Paulo: v. 6 no 1-2, p. 122-149. mai.-nov. 1995. 


\section{ANEXO I}

Tabela 8

Repertório executado pela Banda de Música da Força Pública do Estado de São Paulo durante o ano de 1903

\begin{tabular}{|c|c|c|c|}
\hline Música & Autor & Gênero & Execuções/1903 \\
\hline Hino Nacional Brasileiro & Francisco M. da Silva & Hino & 1 \\
\hline Hino das Nações & Verdi & Hino & 1 \\
\hline Ernani - cavatina & Verdi & Ópera & 4 \\
\hline Falstaff - phantasia & Verdi & Ópera & 2 \\
\hline Luísa Miller & Verdi & Ópera & 5 \\
\hline La Traviata & Verdi & Ópera & 5 \\
\hline Ernani - cavatina & Verdi & Ópera & 1 \\
\hline Il Trovador - ária & Verdi & Ópera & 4 \\
\hline A força do destino - symphonia & Verdi & Ópera & 8 \\
\hline Macbeth - prelúdio & Verdi & Ópera & 4 \\
\hline Aida $2^{\circ}$ ato & Verdi & Ópera & 4 \\
\hline Simom Bocanegra & Verdi & Ópera & 3 \\
\hline Rigoletto - quarteto/tempesta/finalle & Verdi & Ópera & 4 \\
\hline Rigoletto $-1^{\circ}$ ato $1^{\mathrm{a}}$ parte & Verdi & Ópera & 3 \\
\hline Rigoletto. Prelúdio, quarteto e final. & Verdi & Ópera & 1 \\
\hline Giovanna D'Arco - symphonia & Verdi & Ópera & 6 \\
\hline Ballo in Maschera & Verdi & Ópera & 3 \\
\hline Vésperas Sicilianas - abertura & Verdi & Concerto & 3 \\
\hline Otello & Verdi & Ópera & 2 \\
\hline Nabucodonossor & Verdi & Ópera & 1 \\
\hline Tosca $1^{\circ}$ ato & Puccini & Ópera & 8 \\
\hline Tosca $2^{\circ}$ ato & Puccini & Ópera & 4 \\
\hline Tosca $3^{\circ}$ ato & Puccini & Ópera & 11 \\
\hline Manon Lescaut $-3^{\circ}$ ato & Puccini & Ópera & 1 \\
\hline La Boheme $1^{\circ}$ ato & Puccini & Ópera & 1 \\
\hline La Boheme $3^{\circ}$ ato & Puccini & Ópera & 5 \\
\hline La Boheme - dueto & Puccini & Ópera & 1 \\
\hline Dimmi chi sei? & Marchetti & Passo doble & 1 \\
\hline Le Camelie & Marchetti & Passo doble & 1 \\
\hline L'Ezultanza & Marchetti & Passo doble & 6 \\
\hline Ruy Blas - phantasia & Marchetti & Concerto & 1 \\
\hline A Bella Florentina & Marchetti & Polca & 3 \\
\hline Il Duello & Marchetti & Passo doble & 1 \\
\hline Lohengrin - phantasia $1^{\circ}$ ato & Wagner & Ópera & 3 \\
\hline Lohengrin - conto final & Wagner & Ópera & 2 \\
\hline O crepúsculo dos deuses & Wagner & Ópera & 3 \\
\hline Tannhauser - symphonia & Wagner & Ópera & 8 \\
\hline Os mestres cantores de Nuremberg & Wagner & Ópera & 1 \\
\hline Murmúrio da Floresta & Wagner & Ópera & 1 \\
\hline Rienzi - symphonia & Wagner & Ópera & 6 \\
\hline Sigfried & Wagner & Ópera & 2 \\
\hline Guilherme Tell - symphonia & Rossini & Ópera & 7 \\
\hline Simiramide - symphonia & Rossini & Ópera & 5 \\
\hline
\end{tabular}




\begin{tabular}{|c|c|c|c|}
\hline Moysés & Rossini & Marcha & 4 \\
\hline A. Vesella & Rossini & Marcha & 1 \\
\hline Sympnhonia do Guarany & Carlos Gomes & Ópera & 7 \\
\hline Salvador Rosa & Carlos Gomes & Ópera & 4 \\
\hline Il Fuoco & Meyerbeer & Passo doble & 3 \\
\hline Os Hugenotes & Meyerbeer & Ópera & 3 \\
\hline Schiller & Meyerbeer & Marcha & 2 \\
\hline Roberto do diabo & Meyerbeer & Concerto & 2 \\
\hline Aurora & N.N. & Valsa & 1 \\
\hline La pace - prelúdio symphonico & N.N. & Concerto & 2 \\
\hline Amália & N.N. & Mazurca & 4 \\
\hline Marcha Triumphal & N.N. & Marcha & 2 \\
\hline Bagnello & N.N. & Dobrado & 1 \\
\hline L'Ingenua & N.N. & Mazurca & 4 \\
\hline Madrileno & N.N. & Dobrado & 1 \\
\hline Frascuello & N.N. & Dobrado & 1 \\
\hline Margarida & N.N. & Polca & 2 \\
\hline Artigo 9 & N.N. & Dobrado & 1 \\
\hline Saudades & N.N. & Polca & 2 \\
\hline Ramalho & N.N. & Dobrado & 1 \\
\hline $\mathrm{N}^{\circ} 5$ & N.N. & Marcha & 1 \\
\hline Congressista & N.N. & Dobrado & 2 \\
\hline Ébrio & N.N. & Valsa & 1 \\
\hline La Gioconda. Finale IV ato. & Ponchielli & Ópera & 17 \\
\hline I Promessi Sposi - coro & Ponchielli & Ópera & 13 \\
\hline Filho pródigo & Ponchielli & Ópera & 6 \\
\hline Marien Delerme & Ponchielli & Concerto & 2 \\
\hline Omaggio a Donizetti & Ponchielli & Concerto & 1 \\
\hline Itália & Muscente & Mazurca & 4 \\
\hline A volta de Campos Salles & Muscente & Marcha & 2 \\
\hline Lembrança do Paraná & Muscente & Marcha & 7 \\
\hline Margarida & Muscente & Polca & 3 \\
\hline Onde di Lago & Mariani & Valsa & 3 \\
\hline Rosa dele Alpi & Mariani & Mazurca & 2 \\
\hline Ancitá & Mariani & Mazurca & 1 \\
\hline Omagio a Chopin & Mariani & Valsa & 2 \\
\hline Gipsie Carnavalesche & Mariani & Valsa & 1 \\
\hline Dottrine & Strauss & Valsa & 4 \\
\hline Harmonia das espheras & Strauss & Valsa & 3 \\
\hline Polimia & Strauss & Valsa & 1 \\
\hline Vallatore & Strauss & Marcha & 1 \\
\hline Rosas sem espinhos & Strauss & Valsa & 1 \\
\hline Symphonia característica & Morandi & Concerto & 3 \\
\hline Il valto maníaco - symphonia & Morandi & Concerto & 1 \\
\hline La Pace - prelúdio symphonico & Morandi & Concerto & 4 \\
\hline Baile maníaco - symphonia & Morandi & Concerto & 1 \\
\hline Souciens-toi - suíte & Waldteufel & Concerto & 1 \\
\hline Morena ou loura & Waldteufel & Concerto & 2 \\
\hline Sirènes & Waldteufel & Valsa & 4 \\
\hline Ilusão & Waldteufel & Valsa & 1 \\
\hline Violeta & Waldteufel & Valsa & 1 \\
\hline
\end{tabular}




\begin{tabular}{|c|c|c|c|}
\hline Mauriziana & Ferrari & Marcha & 2 \\
\hline Pellegrini & Ferrari & Polca & 2 \\
\hline L'Ancietá & Ferrari & Mazurca & 1 \\
\hline Marcha de Oberon & Weber & Ópera & 1 \\
\hline Marcha Ungherese & Weber & Concerto & 2 \\
\hline Saudação ao Brasil & J. B. D'Arce & Valsa & 5 \\
\hline Pepyta & J. B. D'Arce & Mazurca & 1 \\
\hline Laura & J. B. D'Arce & Concerto & 1 \\
\hline Zezé & J. B. D'Arce & Valsa & 1 \\
\hline Hymno do Divino Espírito Santo & S. Passero & Sacro & 1 \\
\hline Amor Paternal & S. Passero & Ópera & 1 \\
\hline Saudades de Mogy das Cruzes & J. P. Tavares & Dobrado & 3 \\
\hline Tu dirás & J. P. Tavares & Valsa & 2 \\
\hline Caiu na rede & J. P. Tavares & Polca & 2 \\
\hline Vamos à floresta? & J. P. Tavares & Polca & 1 \\
\hline Noturno & Franceschini & Concerto & 3 \\
\hline Poema symphonico & Franceschini & Concerto & 3 \\
\hline Recuerdo de La guerra de África & Heredero & Concerto & 1 \\
\hline Serenata Arata & Mancini & Concerto & 1 \\
\hline Mazurca & Mancini & Mazurca & 1 \\
\hline Marcha triumphal 16 & Mancini & Marcha & 3 \\
\hline Baile de amor - phantasia & Marenco & Concerto & 3 \\
\hline Baile Excelsior - pout pourri & Marenco & Popular & 1 \\
\hline Marcha Nupcial & Mendelssohn & Concerto & 2 \\
\hline Ruy Blas - Overture & Mendelssohn & Ópera & 2 \\
\hline Argento Vivo & De Benedictis & Polca & 1 \\
\hline L'ideale & De Benedictis & Mazurca & 3 \\
\hline Veneza & De Benedictis & Mazurca & 3 \\
\hline La morena & De Benedictis & Marcha & 1 \\
\hline A chiaror di Luna & De Benedictis & Concerto & 3 \\
\hline Serenata & Schubert & Concerto & 2 \\
\hline Omniptência & Schubert & Concerto & 4 \\
\hline Sinfonia $\mathrm{n}^{\mathrm{o}} 1$ (completa) & Beethoven & Concerto & 2 \\
\hline Sinfonia $\mathrm{n}^{\circ} 1$ - Adagio cantábile & Beethoven & Concerto & 2 \\
\hline Cavalaria Rusticana - phantasia & Mascagni & Ópera & 5 \\
\hline Iris - prelúdio & Mascagni & Ópera & 2 \\
\hline Romance di Pierrot e de Pierotte & Burgmein & Concerto & 4 \\
\hline Phantasia Ungherese & Burgmein & Concerto & 1 \\
\hline Il retorno dei prisioneiri italiani & Mario & Marcha & 1 \\
\hline Piedigrotta & Mario & Marcha & 1 \\
\hline Il Pagliacci $-1^{\circ}$ ato & Leoncavallo & Ópera & 4 \\
\hline Il Pagliacci $-2^{\circ}$ ato & Leoncavallo & Ópera & 2 \\
\hline La estrela polare & Orlando & Marcha & 1 \\
\hline Poeta e camponez & Orlando & Passo doble & 2 \\
\hline Libertá dei prigionieri italiani & Orlando & Marcha & 1 \\
\hline Alice & Leandro & Polca & 2 \\
\hline Amor Saudoso & D. P. Tavares & Valsa & 4 \\
\hline Nathurius & G. Lamaire & Concerto & 1 \\
\hline Ricordi & Ascolesse & Valsa & 3 \\
\hline Poeta e contadino - abertura & Suppè & Concerto & 4 \\
\hline Bologna & Rivela & Marcha & 2 \\
\hline
\end{tabular}




\begin{tabular}{|c|c|c|c|}
\hline Carmem & Bizet & Ópera & 2 \\
\hline A Flauta mágica & Mozart & Ópera & 2 \\
\hline Valsa Lenta & Oswald & Valsa & 6 \\
\hline Fausto - phantasia & Gounod & Ópera & 7 \\
\hline O Rei de Lahore - symphonia & Massenet & Ópera & 8 \\
\hline La Norma, simphonia & Bellini & Ópera & 3 \\
\hline Santos Dumont & Luiz Levy & Marcha & 2 \\
\hline Samba: suíte brasillienne & Alexandre Levy & Popular & 4 \\
\hline Marcia dei Croati & Schumann & Concerto & 2 \\
\hline Zizi & Siciliano & Mazurca & 4 \\
\hline Mattino Campestre & Marini & Concerto & 2 \\
\hline Pariz & Metrès & Valsa & 4 \\
\hline Gran via & Valverde & Ópera & 2 \\
\hline Entre as nuvens & Capitani & Valsa & 4 \\
\hline Natália & Pepe & Mazurca & 1 \\
\hline Canti d'Amore & Vitelli & Valsa & 7 \\
\hline O mestre de Capella - symphonia & Paer & Concerto & 2 \\
\hline La Sensitiva & Marco & Polca & 1 \\
\hline Profumo de une fiore & V. Devalle & Valsa & 6 \\
\hline Buon Capo d'anno & Schiavoni & Concerto & 1 \\
\hline Peace forever & J. Zacalle & Marcha & 1 \\
\hline Juju & A. Gouveia & Polca & 4 \\
\hline Le Regiment de Sambre et Meuse & Planquette & Passo doble & 3 \\
\hline The stars and stripes forever & J. P. Souza & Marcha & 3 \\
\hline Babilage & Gillet & Concerto & 2 \\
\hline Candinha & J. Santos & Polca & 1 \\
\hline Polka & Billema & Polca & 1 \\
\hline Paris & Meira & Valsa & 1 \\
\hline Pout-pourri originale & Nocentini & Valsa & 7 \\
\hline Nathalie & Pagano & Valsa & 2 \\
\hline A Rainha Margarida & Lopes & Concerto & 6 \\
\hline Carmaval (?) & Piget & Concerto & 1 \\
\hline Manuelita & Filisberto & Polca & 4 \\
\hline Ricordi di Viaggio & Mussi & Marcha & 2 \\
\hline Pileka & Palmiere & Polca & 2 \\
\hline Cantabile & Marchi & Mazurca & 1 \\
\hline Sonhos de moça & C. Dias & Mazurca & 1 \\
\hline Tentação & Bolognese & Valsa & 3 \\
\hline Lolita & Walcoris & Valsa & 3 \\
\hline La Place & Morandi & Concerto & 2 \\
\hline Adele & Mantovani & Polca & 2 \\
\hline Ravedimento e Perdono & Pincenza & Mazurca & 1 \\
\hline La Patria & G. Cammarato & Marcha & 1 \\
\hline Torino & J. Avallone & Valsa & 1 \\
\hline Zanetta - symphonia & Auler & Concerto & 1 \\
\hline Marcha militar & D. Alfonso & Marcha & 2 \\
\hline Duchino & Lecoq & Ópera & 4 \\
\hline Triumpho & Trigueiro & Dobrado & 1 \\
\hline Mefistófeles & Boito & Ópera & 3 \\
\hline Dansa macabra & Saint Saens & Concerto & 4 \\
\hline Marcha Triumphal & Manente & Marcha & 3 \\
\hline
\end{tabular}




\begin{tabular}{|c|c|c|c|}
\hline Amor discreto & Resch & Concerto & 4 \\
\hline Os sem vintém & Sabine & Dobrado & 1 \\
\hline Cleópatra - Marcha Triumphal & Mancinelli & Marcha & 3 \\
\hline Dansa original & Collucci & Concerto & 4 \\
\hline Amor Fraterno & Grasso & Mazurca & 2 \\
\hline Paraná & D’Aló & Marcha & 2 \\
\hline Dalle Melodie di Caracciolo & Amaroli & Concerto & 1 \\
\hline $\begin{array}{l}\text { Phantasia sobre as célebres melodias } \\
\text { de Caracclolo }\end{array}$ & Azzaroli & Concerto & 1 \\
\hline Christoforo Colombo & Franchetti & Ópera & 2 \\
\hline O sentimento - canção napolitana & Di Capua & Canção & 1 \\
\hline Ronde d'amour & Charlys & Canção & 1 \\
\hline Symphonia em do menor & J. Foroni & Concerto & 3 \\
\hline Cari & Giovanelli & Mazurca & 2 \\
\hline I Mirti D’Oro & $?$ & Valsa & 1 \\
\hline Stephanie & Czilulha & Concerto & 1 \\
\hline Polca & Mesquita & Polca & 1 \\
\hline Serata dei piacere & Florentini & Polca & 1 \\
\hline Loreley & Catalani & Ópera & 1 \\
\hline Lucia de Lammermour - final & Donizetti & Ópera & 2 \\
\hline La bandeira operaria & Biancone & Passo doble & 1 \\
\hline Júlio de Castilhos & Virgílio & Dobrado & 1 \\
\hline Polca & Bilema & Mazurca & 1 \\
\hline Amazona & Meza & Marcha & 1 \\
\hline Adélia & Sabine & Mazurca & 1 \\
\hline
\end{tabular}

\section{Fontes:}

O Estado de São Paulo, São Paulo, 1903.

Correio Paulistano, São Paulo, 1903. 
Tabela 9

Repertório executado pela Banda de Música da Força Pública do Estado de São Paulo durante $\mathrm{o}$ ano de 1915

\begin{tabular}{|c|c|c|c|}
\hline Obra & Autor & Gênero & Execuções/1915 \\
\hline Rienzi - Symphonia & Wagner & Sinfonia & 5 \\
\hline Lohengrin - final do $1^{\circ}$ acto & Wagner & Ópera & 8 \\
\hline Lohengrin - conto e final do $3^{\circ}$ acto & Wagner & Ópera & 3 \\
\hline Euriante & Wagner & Sinfonia & 1 \\
\hline Tannhauser-marcha & Wagner & Marcha & 4 \\
\hline Tannhauser & Wagner & Sinfonia & 6 \\
\hline Os mestres cantores & Wagner & Sinfonia & 1 \\
\hline Violeta & Waldteufel & Valsa & 5 \\
\hline Ange d'amour & Waldteufel & Valsa & 5 \\
\hline Mon rêve & Waldteufel & Valsa & 4 \\
\hline Folle ivresse & Waldteufel & Valsa & 1 \\
\hline Os patinadores & Waldteufel & Valsa & 3 \\
\hline Dreams of Childhoods & Waldteufel & Valsa & 1 \\
\hline Chantilly & Waldteufel & Valsa & 8 \\
\hline Valsa militar & Waldteufel & Valsa & 2 \\
\hline A estudantina & Waldteufel & Valsa & 6 \\
\hline Hespanha & Waldteufel & Valsa & 1 \\
\hline Retour de printamps & Waldteufel & Valsa & 4 \\
\hline Tout Paris & Waldteufel & Valsa & 4 \\
\hline Amout et printamps & Waldteufel & Valsa & 3 \\
\hline Não me olvides & Waldteufel & Valsa & 2 \\
\hline Boheme & Puccini & Fantasia & 7 \\
\hline Ronde des Archers & Burgmein & Concerto & 2 \\
\hline Aida $2^{\circ}$ acto & Verdi & Ópera & 7 \\
\hline Falstaff & Verdi & Fantasia & 5 \\
\hline $\begin{array}{l}\text { Rigoleto - prelúdio quarteto, } \\
\text { tempestade e final }\end{array}$ & Verdi & Concerto & 4 \\
\hline Il Trovador & Verdi & Ópera & 3 \\
\hline Amor de cigano & F. Lehar & Valsa & 3 \\
\hline Conde de Luxemburgo & F. Lehar & Valsa & 2 \\
\hline $\mathrm{O}$ funileiro & F. Lehar & Valsa & 1 \\
\hline Marcha Turca & Mozart & Concerto & 7 \\
\hline Zampa & Herold & Sinfonia & 5 \\
\hline Conto de uma floresta vienense & Strauss & Valsa & 3 \\
\hline Danúbio azul & Strauss & Valsa & 5 \\
\hline Sonho de valsa & Strauss & Valsa & 1 \\
\hline Mephistopheles & Boito & Fantasia & 5 \\
\hline Entre companheiros d'armas & C. Teike & Marcha & 3 \\
\hline Senha imperial & C. Teike & Marcha & 5 \\
\hline Velhos camaradas & C. Teike & Marcha & 1 \\
\hline Borussia & C. Teike & Marcha & 4 \\
\hline Fidelidade constante & C. Teike & Marcha & 2 \\
\hline O Barbeiro de Sevilha - pout pourri & Rosssini & Ópera & 1 \\
\hline Segunda rapsódia & Liszt & Concerto & 1 \\
\hline Oberon & Weber & Sinfonia & 2 \\
\hline
\end{tabular}




\begin{tabular}{|c|c|c|c|}
\hline Euriante & Weber & Sinfonia & 4 \\
\hline Perdidos nas trevas & S. Donaudy & Fantasia & 4 \\
\hline Rapsódia javanesa & P. Seelig & Concerto & 2 \\
\hline Cavalaria rusticana & Mascagni & Fantasia & 2 \\
\hline Iris hino ao sol & Mascagni & Abertura & 5 \\
\hline A victoria da Juliana & B. Ollgema & Marcha & 2 \\
\hline Recordação da guerra da África & H. Eredero & Fantasia & 3 \\
\hline Princeza dos dollars & Leo Falls & Valsa & 1 \\
\hline Carmem - pout-pourri & G. Bizet & Ópera & 6 \\
\hline Fausto & Gounod & Fantasia & 10 \\
\hline Marcha dos Ascari & Frontini & Marcha & 5 \\
\hline Salve Pátria & P. Nimac & Marcha & 4 \\
\hline Estrela do Norte & Meyerbeer & Sinfonia & 3 \\
\hline Sonnambula & Bellini & Fantasia & 6 \\
\hline A japoneza & Pryor & Marcha & 1 \\
\hline Dansa das serpentes & Boccalari & Concerto & 5 \\
\hline Ouverture de concerto & Giraud & Abertura & 4 \\
\hline Valsa lenta & H. Oswald & Valsa & 1 \\
\hline Samba - suíte brasilienne & A. Levy & Popular & 1 \\
\hline Tango brasileiro & A. Levy & Tango & 1 \\
\hline Paschoa Fiorentina & N.N. & $? ?$ & 2 \\
\hline O Guarany & C. Gomes & Sinfonia & 1 \\
\hline O Guarany - fantasia & C. Gomes & Fantasia & 1 \\
\hline Salvador Rosa & C. Gomes & Fantasia & 3 \\
\hline Ao Ceará livre & C. Gomes & Marcha & 1 \\
\hline Brasil & F. Braga & Hino/Marcha & 2 \\
\hline Scherzzo & João Gomes & Concerto & 1 \\
\hline Cateretê mineiro & Martins & Popular & 2 \\
\hline Vida Nova & Frosalli & Sinfonia & 1 \\
\hline The Geisha & S. Jones & Fantasia & 1 \\
\hline Priorri & Cremieuk & Valsa & 1 \\
\hline Os granadeiros pout-pourri & Valente & Fantasia & 1 \\
\hline Marisha Czardas & Michelli & Concerto & 1 \\
\hline Marcha Nupcial & Mendelssohn & Marcha & 2 \\
\hline Gioconda - dansa das horas & Ponchielli & Ópera & 6 \\
\hline Gioconda - coro prelúdio e romance & Ponchielli & Ópera & 4 \\
\hline Amor de príncipe - valsa das rosas & Ed. Eysler & Valsa & 4 \\
\hline Casta Suzanna & J. Gilbert & Marcha & 1 \\
\hline Bayadére - dansa indiana & M. Piedade & $? ? ? ?$ & 1 \\
\hline O rei de Lahore & Massenet & Sinfonia & 2 \\
\hline Patrulha americana & Meachan & Jazz/ Pop & 2 \\
\hline Valsa d'amour & M. Ziehrer & Valsa & 2 \\
\hline Symphonia em dó menor & Foroni & Sinfonia & 5 \\
\hline Moyses & Rossini & Marcha & 2 \\
\hline
\end{tabular}

\section{Fonte:}

O Estado de São Paulo, São Paulo, 1915. 
Tabela 10

Repertório executado pela Banda de Música da Força Pública do Estado de São Paulo durante o ano de 1925

\begin{tabular}{|l|l|c|c|}
\hline \multicolumn{1}{|c|}{ Obra } & \multicolumn{1}{c|}{ Autor } & Gênero & $\begin{array}{c}\text { Execuções } \\
\mathbf{1 9 2 5}\end{array}$ \\
\hline Don Carlos, Gran finale $-3^{\mathbf{0}}$ acto & Verdi & Ópera & 2 \\
\hline Rigoletto $-1^{\mathbf{o}}$ Acto & Verdi & Ópera & 2 \\
\hline O Guarany - Symphonia & Carlos Gomes & Ópera & 2 \\
\hline Salvador Rosa - Phantasia & Carlos Gomes & Ópera & 1 \\
\hline Tango Brasileiro & A. Levy & Popular & 1 \\
\hline Samba - Suite Bresilienne & A. Levy & Popular & 1 \\
\hline Moysés & G. Rossini & Ópera & 2 \\
\hline Conto de uma floresta Viennense & Strauss & Valsa & 2 \\
\hline Scena Pittoresche & Massenet & Concerto & 2 \\
\hline Zampa - Symphonia & L. F. Hereld & Ópera & 1 \\
\hline Omero & C. Chiuneri & Valsa & 1 \\
\hline Marcha Degli Ascari & F. P. Frontini & Marcha & 1 \\
\hline $3^{\text {a Symphonia em mi bemol }}$ & J. Gomes de Araújo & Concerto & 1 \\
\hline
\end{tabular}

Fonte:

Força Pública do Estado de São Paulo. Boletins Gerais, São Paulo: 1925. 


\section{Tabela 11}

Repertório executado pela Banda de Música da Força Pública do Estado de São Paulo durante o ano de 1926

\begin{tabular}{|c|c|c|c|}
\hline Música & Autor & Gênero & $\begin{array}{c}\text { Execuções } \\
1926\end{array}$ \\
\hline Rigoletto - Quarteto temp. final & Verdi & Ópera & 1 \\
\hline Aída $-2^{\circ}$ acto & Verdi & Ópera & 1 \\
\hline Elegia verdiana & Verdi & Concerto & 3 \\
\hline Il Trovador $-1^{\circ}$ Acto & Verdi & Ópera & 1 \\
\hline O Guarany - Symphonia & Carlos Gomes & Ópera & 2 \\
\hline Salvador Rosa - Phantasia & Carlos Gomes & Ópera & 1 \\
\hline Espanha & E. Waldteufel & Valsa & 1 \\
\hline Barcelona & E. Waldteufel & Valsa & 1 \\
\hline A mais bela & E. Waldteufel & Valsa & 1 \\
\hline Tout Paris & E. Waldteufel & Valsa & 1 \\
\hline Valsa militar & E. Waldteufel & Valsa & 1 \\
\hline Barcarola & E. Waldteufel & Valsa & 1 \\
\hline Serenata & Schubert & Concerto & 1 \\
\hline Omnipotência - Lied & Schubert & Concerto & 2 \\
\hline Guilherme Tell - Symphonia & G. Rossini & Ópera & 2 \\
\hline Oberon - Ouvertura & Weber & Ópera & 1 \\
\hline Jubel - Ouverture & Weber & Concerto & 1 \\
\hline Velhos Camaradas & K. Teike & Marcha & 1 \\
\hline Marcha Turca & Mozart & Concerto & 1 \\
\hline La Sonambula - Phantasia & Bellini & Ópera & 1 \\
\hline Cristoforo Colombo - Peludio $1^{\circ}$ & Franchetti & Ópera & 1 \\
\hline La Gioconda - dansa das horas & Ponchielli & Ópera & 1 \\
\hline Rienzi - Symphonia & Wagner & Ópera & 2 \\
\hline Scena Pittoresche & Massenet & Concerto & 1 \\
\hline Amor despresado & Lincke & Valsa & 2 \\
\hline Carnaval Venetien - suíte & Burgmein & Concerto & 2 \\
\hline Zampa - Symphonia & L. F. Herold & Opera & 1 \\
\hline Canto de amor & E. Vitelli & Valsa & 2 \\
\hline Recordação da guerra da África & H. Eredero & Concerto & 3 \\
\hline Iris, Hymno ao Sol & P. Mascagni & Ópera & 2 \\
\hline Ouvertura de Concerto & Adolfo Girand & Concerto & 1 \\
\hline L'Arlesiana - Phantasia & Giovanni Pennacchi & Concerto & 1 \\
\hline Alma Luzitana & Camillo Berti & Marcha & 1 \\
\hline Serenata & Bolognesi & Concerto & 1 \\
\hline Verschmahte Lieb & Paul Lincke & Valsa & 1 \\
\hline Treue Waffengefahrten & H. L. Blakerberg & Marcha & 1 \\
\hline Carmem - pout pourri & Bizet & Ópera & 1 \\
\hline Marcha & Blankengurg & Marcha & 1 \\
\hline Francesca da Rimini - Symphonia & Morlachi & Ópera & 1 \\
\hline O caro Agostinho & Leo Fall & Valsa & 1 \\
\hline Barcarola - Canto dos Marujos & Cambino & Concerto & 1 \\
\hline Archeduque Alberto & Komzak & Marcha & 1 \\
\hline O mestre de Capella - Symphonia & Paer & Concerto & 2 \\
\hline The dance of the serpente & Boccalari & Concerto & 1 \\
\hline Amour Discret - Gavot & Resch & Concerto & 2 \\
\hline
\end{tabular}




\begin{tabular}{|l|l|c|c|}
\hline Mephistofeles - Phantasia & Boito & Ópera & 2 \\
\hline Marcha & Fregoli & Marcha & 1 \\
\hline Guayaúna & C. Campos & Marcha & 1 \\
\hline Ma bella qui danse & Westerhout & Concerto & 1 \\
\hline Sob a guarda das estrelas & Stieberitz & Marcha & 1 \\
\hline
\end{tabular}

Fonte:

Força Pública do Estado de São Paulo. Boletins Gerais, São Paulo: 1926. 
Tabela 12

Repertório executado pela Banda de Música da Força Pública do Estado de São Paulo durante o ano de 1927

\begin{tabular}{|l|l|c|c|}
\hline \multicolumn{1}{|c|}{ Música } & \multicolumn{1}{c|}{ Autor } & Gênero & $\begin{array}{c}\text { Execuções } \\
\mathbf{1 9 2 7}\end{array}$ \\
\hline Aída - Prelúdio & Verdi & Ópera & 1 \\
\hline Salvador Rosa - Phantasia & Carlos Gomes & Ópera & 2 \\
\hline Samba - Suite Bresilienne & A. Levy & Popular & 1 \\
\hline Valsa militar & E. Waldteufel & Valsa & 1 \\
\hline Os Patinadores & E. Waldteufel & Valsa & 1 \\
\hline Chantilly & E. Waldteufel & Valsa & 1 \\
\hline Violetes & E. Waldteufel & Valsa & 1 \\
\hline Marcha militar & Schubert & Marcha & 1 \\
\hline Guilherme Tell - Symphonia & G. Rossini & Ópera & 1 \\
\hline Jubel - Ouverture & Weber & Concerto & 1 \\
\hline Borussia & K. Teike & Marcha & 1 \\
\hline A filha do bandido & F. Lehar & Valsa & 1 \\
\hline Petit Galline - Intermezzo & Gillet & Concerto & 1 \\
\hline La Gioconda - dansa das horas & Ponchielli & Ópera & 1 \\
\hline O Rei de Lahore - Symphonia & Massenet & Concerto & 2 \\
\hline Verschmahte Liebe & Lincke & Valsa & 1 \\
\hline La Bohemè & Puccini & Ópera & 1 \\
\hline O mestre de Capella - Symphonia & Paer & Concerto & 1 \\
\hline Marcha Militar & Stieberitz & Marcha & 1 \\
\hline Reminiscência de Ballo Sieba & Marengo & Concerto & 2 \\
\hline A gruta de Fingal - Overture & Mendelssohn & Concerto & 1 \\
\hline Patrulha americana & Meacham & Popular & 1 \\
\hline Cavalaria rusticana & Mascagni & Ópera & 1 \\
\hline Adagio Cantabile - Sonata Patética & Beethoven & Concerto & 1 \\
\hline Sahuntala - Symphonia descritiva & Goldmarch & Concerto & 1 \\
\hline Hymno à Jahu & J. Gomes de Araújo & Hino & 1 \\
\hline Ouvertura de Concerto & A. Giraud & Concerto & 1 \\
\hline Homero & Chiusuri & Valsa & 1 \\
\hline Glória - João Negrão & Milhori & Marcha & 1 \\
\hline Mephistófele - 2 Acto & Hoito & Ooncera & 1 \\
\hline Recordação da Guerra da África & Heredero & 2 \\
\hline & & & \\
\hline
\end{tabular}

Fonte:

Força Pública do Estado de São Paulo. Boletins Gerais, São Paulo: 1927. 
Tabela 13

Repertório executado pela Banda de Música da Força Pública do Estado de São Paulo durante o ano de 1928

\begin{tabular}{|c|c|c|c|}
\hline Música & Autor & Gênero & $\begin{array}{c}\text { Execuções } \\
1928 \\
\end{array}$ \\
\hline Rigoletto $-2^{\circ}$ Acto & Verdi & Ópera & 1 \\
\hline Rigoletto - Quarteto temp. final & Verdi & Ópera & 1 \\
\hline Aída - Prelúdio & Verdi & Ópera & 4 \\
\hline Elegia verdiana & Verdi & Concerto & 1 \\
\hline Il Trovador $-1^{\circ}$ Acto & Verdi & Ópera & 2 \\
\hline La Traviata $-3^{\circ}$ Acto & Verdi & Ópera & 3 \\
\hline Joanna D'Arc & Verdi & Ópera & 1 \\
\hline Aroldo - Symphonia & Verdi & Ópera & 1 \\
\hline A força do destino & Verdi & Ópera & 1 \\
\hline O Guarany - Symphonia & Carlos Gomes & Ópera & 7 \\
\hline Salvador Rosa - Phantasia & Carlos Gomes & Ópera & 5 \\
\hline Samba - Suite Bresilienne & A. Levy & Popular & 1 \\
\hline Valsa militar & E. Waldteufel & Valsa & 4 \\
\hline Barcarola & E. Waldteufel & Valsa & 1 \\
\hline Chantilly & E. Waldteufel & Valsa & 4 \\
\hline Violetes & E. Waldteufel & Valsa & 1 \\
\hline A estudiantina & E. Waldteufel & Valsa & 5 \\
\hline Dolores & E. Waldteufel & Valsa & 1 \\
\hline Retour du Printemp & E. Waldteufel & Valsa & 3 \\
\hline Mon Rêve & E. Waldteufel & Valsa & 2 \\
\hline Confidência & E. Waldteufel & Valsa & 2 \\
\hline Os patinadores & E. Waldteufel & Valsa & 1 \\
\hline Omnipotência - Lied & Schubert & Concerto & 1 \\
\hline Guilherme Tell - Symphonia & G. Rossini & Ópera & 1 \\
\hline Oberon - Ouvertura & Weber & Ópera & 4 \\
\hline Euriante - Symphonia & Weber & Concerto & 3 \\
\hline Fidelidade constante & K. Teike & Marcha & 2 \\
\hline Senha Imperial & K. Teike & Marcha & 3 \\
\hline Marcha militar & K. Teike & Marcha & 4 \\
\hline Conde de Zepellin & K. Teike & Marcha & 1 \\
\hline Sonho das Fadas & Delle Cese & Valsa & 2 \\
\hline A Flauta Mágica - Abertura & Mozart & Ópera & 3 \\
\hline Le nozze de Fígaro & Mozart & Ópera & 5 \\
\hline A filha do bandido & F. Lehar & Valsa & 3 \\
\hline Matrimônio & F. Lehar & Marcha & 1 \\
\hline Tiralalá & Strauss & Valsa & 4 \\
\hline O soldado de chocolate & Strauss & Valsa & 4 \\
\hline Danúbio Azul & Strauss & Valsa & 5 \\
\hline Babillage & Gillet & Concerto & 1 \\
\hline La Sonambula - Phantasia & Bellini & Ópera & 7 \\
\hline Norma - pout pourri & Bellini & Ópera & 1 \\
\hline Cristoforo Colombo - Peludio $1^{\circ}$ & Franchetti & Ópera & 5 \\
\hline Marcha militar & Franchetti & Marcha & 4 \\
\hline Germania - quadro $2^{\circ}$ & Franchetti & Ópera & 4 \\
\hline
\end{tabular}




\begin{tabular}{|c|c|c|c|}
\hline A filha de Ioiro - phantasia $1^{\circ}$ Acto & Franchetti & Ópera & 6 \\
\hline La Gioconda - dansa das horas & Ponchielli & Ópera & 3 \\
\hline I promessi Sposi - coro e sermão & Ponchielli & Ópera & 1 \\
\hline Gioconda - phantasia & Ponchielli & Ópera & 6 \\
\hline Amor de Príncipe & Ed. Eysler & Valsa & 4 \\
\hline Vera Violeta & Ed. Eysler & Valsa & 2 \\
\hline Rienzi - Symphonia & Wagner & Ópera & 3 \\
\hline Lohengrin & Wagner & Ópera & 3 \\
\hline Scena Pittoresche & Massenet & Concerto & 6 \\
\hline O Rei de Lahore - Symphonia & Massenet & Concerto & 2 \\
\hline Erodiade - coro dos romanos & Massenet & Concerto & 4 \\
\hline Verschmahte Liebe & Lincke & Valsa & 3 \\
\hline La Bohemè & Puccini & Ópera & 4 \\
\hline Manon Lecout - phantasia & Puccini & Ópera & 2 \\
\hline Loreley - phantasia & Catalani & Ópera & 6 \\
\hline Zampa-Symphonia & L. F. Hereld & Ópera & 5 \\
\hline Marcha Degli Ascari & F. P. Frontini & Marcha & 2 \\
\hline Canto de amor & R. Vitelli & Valsa & 5 \\
\hline Serenata & Bolognesi & Concerto & 6 \\
\hline Francesca da Rimini - Symphonia & Morlachi & Ópera & 2 \\
\hline O caro Agostinho & Leo Fall & Valsa & 3 \\
\hline Barcarola - Canto dos Marujos & Cambino & Concerto & 1 \\
\hline Archeduque Alberto & Komzak & Marcha & 2 \\
\hline O mestre de Capella - Symphonia & Paer & Concerto & 3 \\
\hline The dance of the serpente & Boccalari & Concerto & 1 \\
\hline Mephistofeles - Phantasia & Boito & Ópera & 8 \\
\hline Marcha Militar & E. Stieberitz & Marcha & 1 \\
\hline Reminiscência de Ballo Sieba & Marengo & Concerto & 3 \\
\hline A gruta de Fingal - Overture & Mendelssohn & Concerto & 2 \\
\hline Adagio Cantabile - Sonata Patética & Beethoven & Concerto & 2 \\
\hline Sakuntala - Symphonia descritiva & Goldmarch & Concerto & 2 \\
\hline Ouvertura de Concerto & A. Giraud & Concerto & 2 \\
\hline Homero & Chiusuri & Valsa & 2 \\
\hline Saul-Ouverture & Bazzini & Concerto & 4 \\
\hline Aviação Paulista & E. C. Vinagre & Marcha & 2 \\
\hline Sonho das Sibyllas & Mirinis & Valsa & 2 \\
\hline Linho e Seda & Ziekrer & Valsa & 1 \\
\hline Valsa de amor & Ziekrer & Valsa & 2 \\
\hline Os huguenotes - phantasia & Meyerbeer & Ópera & 2 \\
\hline Sammt und seide & E. Patzke & Valsa & 2 \\
\hline Casta Susanna & J. Gilbert & Marcha & 1 \\
\hline Mau tempo & Zeit & Marcha & 3 \\
\hline Cambrinus & Beccucci & Valsa & 1 \\
\hline Marcha Militar & N.N. & Marcha & 6 \\
\hline Cleópatra & Monsinelli & Marcha & 5 \\
\hline Fausto & Gounod & Ópera & 5 \\
\hline Rhapsodia Hongroise & Liszt & Concerto & 5 \\
\hline Sul Verone - phantasia & Petrucelli & Concerto & 1 \\
\hline Legalidade & De Nicolo & Marcha & 1 \\
\hline Bons camaradas & R. Meza & Marcha & 3 \\
\hline Marcha militar & Stieberitz & Marcha & 1 \\
\hline
\end{tabular}




\begin{tabular}{|l|l|c|c|}
\hline Marcha militar & Hall & Marcha & 3 \\
\hline Recordação da Guerra da África & Heredero & Concerto & 4 \\
\hline Marcha militar & Silvio & Marcha & 5 \\
\hline O anjo da meia noite - phantasia & Carlini & Concerto & 4 \\
\hline Symphonia em Do menor & Foroni & Concerto & 3 \\
\hline Caresses & Browin & Valsa & 4 \\
\hline Hymno Nacional Brasileiro & Fco. Manoel da Silva & Hino & 1 \\
\hline Hymno Procl. República & Leopoldo Miguez & Hino & 1 \\
\hline Dançante & Bressan & Valsa & 2 \\
\hline
\end{tabular}

Fonte:

Força Pública do Estado de São Paulo. Boletins Gerais, São Paulo: 1928. 
Tabela 14

Repertório executado pela Banda de Música da Força Pública do Estado de São Paulo durante o ano de 1929

\begin{tabular}{|c|c|c|c|}
\hline Música & Autor & Gênero & $\begin{array}{c}\text { Execuções } \\
1929\end{array}$ \\
\hline Don Carlos, Gran finale $-3^{\circ}$ acto & Verdi & Ópera & 2 \\
\hline Rigoletto - Quarteto temp. final & Verdi & Ópera & 2 \\
\hline Aída $-2^{\circ}$ acto & Verdi & Ópera & 3 \\
\hline Il Trovador $-1^{\circ}$ Acto & Verdi & Ópera & 1 \\
\hline La Traviata $-3^{\circ}$ Acto & Verdi & Ópera & 3 \\
\hline I Vespri Siciliani - Phantasia & Verdi & Ópera & 3 \\
\hline O Guarany - Symphonia & Carlos Gomes & Ópera & 3 \\
\hline Salvador Rosa - Phantasia & Carlos Gomes & Ópera & 1 \\
\hline Lo Schiavo- $3^{\circ}$ Acto & Carlos Gomes & Ópera & 4 \\
\hline Ave Maria - O Guarany & Carlos Gomes & Ópera & 1 \\
\hline Canção do Aventureiro/ O Guarany & Carlos Gomes & Ópera & 1 \\
\hline Tango Brasileiro & A. Levy & Popular & 2 \\
\hline Samba - Suite Bresilienne & A. Levy & Popular & 1 \\
\hline Chantilly & E. Waldteufel & Valsa & 3 \\
\hline A estudiantina & E. Waldteufel & Valsa & 2 \\
\hline Dolores & E. Waldteufel & Valsa & 2 \\
\hline Mon Rêve & E. Waldteufel & Valsa & 1 \\
\hline Sonho de criança & E. Waldteufel & Valsa & 2 \\
\hline Pluie D’Or & E. Waldteufel & Valsa & 4 \\
\hline Não me olvides & E. Waldteufel & Valsa & 2 \\
\hline Ange D'Amour & E. Waldteufel & Valsa & 2 \\
\hline Momento musical - Lied & Schubert & Concerto & 2 \\
\hline Guilherme Tell - Symphonia & G. Rossini & Ópera & 6 \\
\hline Oberon - Ouvertura & Weber & Ópera & 5 \\
\hline Jubel - Ouverture & Weber & Concerto & 2 \\
\hline Senha Imperial & K. Teike & Marcha & 1 \\
\hline Conde de Zepellin & K. Teike & Marcha & 3 \\
\hline A vinda do Imperador & K. Teike & Marcha & 5 \\
\hline Regresso do Kaiser & K. Teike & Marcha & 5 \\
\hline A Flauta Mágica - Abertura & Mozart & Ópera & 1 \\
\hline A filha do bandido & F. Lehar & Valsa & 4 \\
\hline O Funileiro & F. Lehar & Valsa & 1 \\
\hline Amor de Príncipe & F. Lehar & Valsa & 1 \\
\hline Danúbio Azul & Strauss & Valsa & 2 \\
\hline Seduction & Gillet & Valsa & 2 \\
\hline La Gioconda - dansa das horas & Ponchielli & Ópera & 4 \\
\hline Lohengrin & Wagner & Ópera & 6 \\
\hline Scena Pittoresche & Massenet & Concerto & 1 \\
\hline Amor despresado & Lincke & Valsa & 2 \\
\hline La Bohemè & Puccini & Ópera & 5 \\
\hline Manon Lecout - phantasia & Puccini & Ópera & 4 \\
\hline Turandot & Puccini & Ópera & 7 \\
\hline Edgar - Phantasia & Puccini & Ópera & 4 \\
\hline Despedida dos gladiadores & Blackenburg (Blankenburg) & Marcha & 2 \\
\hline
\end{tabular}




\begin{tabular}{|c|c|c|c|}
\hline Carnaval Venetien - suíte & Burgmein & Concerto & 5 \\
\hline Em Revant. & Burgmein & Marcha & 2 \\
\hline A Wally - Phantasia & Catalani & Ópera & 1 \\
\hline Marcha Degli Ascari & F. P. Frontini & Marcha & 2 \\
\hline Recordação da guerra da África & H. Eredero & Concerto & 4 \\
\hline Iris, Hymno ao Sol & Pietro Mascagni & Ópera & 5 \\
\hline Carmem - pout pourri & Georges Bizet & Ópera & 2 \\
\hline Archeduque Alberto & Karel Komzak & Marcha & 1 \\
\hline O mestre de Capella - Symphonia & Paer & Concerto & 1 \\
\hline The dance of the serpent & Boccalari & Concerto & 2 \\
\hline Gran Marcha & Fregoli & Marcha & 1 \\
\hline Reminiscência de Ballo Sieba & Marengo & Concerto & 2 \\
\hline Ouvertura de Concerto & A. Giraud & Concerto & 5 \\
\hline Homero & Chiusuri & Valsa & 1 \\
\hline Saul-Ouverture & Bazzini & Concerto & 2 \\
\hline Linho e Seda & Ziehrer & Valsa & 2 \\
\hline Os huguenotes - phantasia & Meyerbeer & Ópera & 1 \\
\hline Mau tempo & Zeit (Hackenberger) & Marcha & 1 \\
\hline Fausto & Gounod & Ópera & 1 \\
\hline Symphonia em Do menor & Foroni & Concerto & 1 \\
\hline Caresses & Browin (Brown) & Valsa & 1 \\
\hline Dançante & Bressan & Valsa & 2 \\
\hline A rainha do baile & J. Ivanovici & Valsa & 5 \\
\hline Dansa dos sultanos & F. Floridia & Concerto & 5 \\
\hline Ruy Blas $-4^{\circ}$ Acto & Marchetti & Ópera & 8 \\
\hline Marcha militar & Honrak & Marcha & 1 \\
\hline Rogério & Russo & Marcha & 6 \\
\hline Goyaz & Arruda & Marcha & 1 \\
\hline Marcha Militar & Arruda & Marcha & 1 \\
\hline A Baixo Porto - Phantasia & Spinelli & Concerto & 2 \\
\hline Lolita & Walcoeis & Valsa & 3 \\
\hline Cortejo oriental & Canne & Marcha & 1 \\
\hline Conchita - Phantasia & Zandonai & Ópera & 1 \\
\hline Cinema & Farina & Marcha & 1 \\
\hline Elegia verdiana & Filippo Codivilla & Concerto & 1 \\
\hline I Dispetti Amorosi - Phantasia & G. Luporini & Concerto & 3 \\
\hline Sognando & Gasperoni & Valsa & 3 \\
\hline I Dispetti Amorosi - Phantasia & Suporini & Concerto & 1 \\
\hline Il Maestro Di Capella - Symphonia & Ascolese & Ópera & 3 \\
\hline Princesa dos Dólares & Leo Falls & Valsa & 4 \\
\hline Patrulha americana & Meachan & Popular & 2 \\
\hline
\end{tabular}

Fonte:

Força Pública do Estado de São Paulo. Boletins Gerais, São Paulo: 1929. 


\section{Tabela 15}

Repertório executado pela Banda de Música da Força Pública do Estado de São Paulo durante o ano de 1930

\begin{tabular}{|l|l|c|c|}
\hline \multicolumn{1}{|c|}{ Música } & \multicolumn{1}{|c|}{ Autor } & Gênero & $\begin{array}{c}\text { Execuções } \\
\mathbf{1 9 3 0}\end{array}$ \\
\hline Don Carlos, Gran finale $-3^{\circ}$ acto & Verdi & Ópera & 2 \\
\hline La Traviata $-3^{\circ}$ Acto & Verdi & Ópera & 2 \\
\hline I Vespri Siciliani - Phantasia & Verdi & Ópera & 2 \\
\hline O Guarany - Symphonia & Carlos Gomes & Ópera & 1 \\
\hline Ave Maria - O Guarany & Carlos Gomes & Ópera & 2 \\
\hline Samba - Suite Bresilienne & A. Levy & Popular & 1 \\
\hline Espanha & E. Waldteufel & Valsa & 1 \\
\hline A estudiantina & E. Waldteufel & Valsa & 1 \\
\hline Dolores & E. Waldteufel & Valsa & 2 \\
\hline Pluie D’Or & E. Waldteufel & Valsa & 1 \\
\hline Borussia & K. Teike & Marcha & 3 \\
\hline Senha Imperial & K. Teike & Marcha & 2 \\
\hline Conde de Zepellin & K. Teike & Marcha & 1 \\
\hline Entre companheiros d'arma & K. Teike & Marcha & 1 \\
\hline A filha do bandido & F. Lehar & Valsa & 2 \\
\hline Amor de cigano & F. Lehar & Valsa & 1 \\
\hline Tiralalá & Strauss & Valsa & 2 \\
\hline Danúbio Azul & Strauss & Valsa & 1 \\
\hline O Cigano Barão & Strauss & Valsa & 3 \\
\hline Lohengrin & Wagner & Ópera & 6 \\
\hline Zampa - Symphonia & L. F. Hereld & Ópera & 2 \\
\hline Carmem - pout pourri & Bizet & Ópera & 3 \\
\hline Francesca da Rimini - Symphonia & Morlachi (Marlocchi) & Ópera & 2 \\
\hline Barcarola - Canto dos Marujos & Cambino & Concerto & 3 \\
\hline Ouvertura de Concerto & A. Giraud & Concerto & 1 \\
\hline Saul - Ouverture & A. Bazzini & Concerto & 3 \\
\hline Recordação da Guerra da África & Heredero & Concerto & 1 \\
\hline Symphonia em Do menor & Foroni & Concerto & 1 \\
\hline I Dispetti Amorosi - Phantasia & G. Luporini & Concerto & 2 \\
\hline Príncipe de Ragon & Bruno & Valsa & 1 \\
\hline Canções Brasileiras & Joaquim Antão & & 2 \\
\hline & & & \\
\hline
\end{tabular}

Fonte:

Força Pública do Estado de São Paulo. Boletins Gerais, São Paulo: 1930. 
Tabela 16

Bandas de Música mapeadas na cidade de São Paulo 1888-1932.

\begin{tabular}{|c|c|c|}
\hline \multicolumn{3}{|c|}{ Bandas de Imigrantes ou Associativas } \\
\hline CORPORAÇÃO & MAESTRO & FONTE \\
\hline Banda de Música Italiana & José Máximo & OESP-27Jan 1889 \\
\hline $\begin{array}{l}\text { Banda de Música da Confraria de N. Sra. } \\
\text { dos Remédios }\end{array}$ & José Pinto Tavares & OESP-05Fev1889 \\
\hline $\begin{array}{l}\text { Banda de Música Recreio Artístico ou } \\
\text { Recreio dos Artistas }\end{array}$ & Veríssimo A. Da Glória & $\begin{array}{c}\text { OESP-08Mai1889 } \\
\text { CP-12Fev1890 }\end{array}$ \\
\hline Banda do Club Musical do Riachuelo & $\mathrm{N} / \mathrm{C}$ & OESP-11Mai1889 \\
\hline $\begin{array}{l}\text { Banda de Música do Club } 13 \text { de maio da } \\
\text { Vila de Santo Amaro }\end{array}$ & $\begin{array}{l}\text { Joaquim Antão Fernandes } \\
\text { entre } 1889 \text { e } 1892\end{array}$ & OESP-16Mai1889 \\
\hline Banda de Música Guido Mônaco & Giuseppe de Sicca & OESP 20Set1903 \\
\hline Banda de Música Mônaco Bersaglieri & José de Sicca & OESP 18Ago1889 \\
\hline $\begin{array}{l}\text { Banda de Música União Artística } \\
\text { (operários) }\end{array}$ & $\mathrm{N} / \mathrm{C}$ & OESP-05Jan 1890 \\
\hline $\begin{array}{l}\text { Banda de Música N. Sra. do Rosário dos } \\
\text { Homens Pretos }\end{array}$ & Carlos Cruz & CP-18Jan1888 \\
\hline $\begin{array}{l}\text { Banda do Real Club Gymnástico } \\
\text { Portuguez S. Paulo }\end{array}$ & Maestro Chiafarelli & $\begin{array}{l}\text { CP-25Mar1888 } \\
\text { CP-12Jun1892 }\end{array}$ \\
\hline Banda do Club Suppè & $\mathrm{N} / \mathrm{C}$ & CP-30Out1888 \\
\hline Banda de Operários italianos Umberto I & Carmine Prefetto & $\begin{array}{l}\text { CP-04Fev1890 } \\
\text { OSP-06Jun1891 }\end{array}$ \\
\hline $\begin{array}{l}\text { Banda de Música do Club dos Voluntários } \\
\text { da Pátria }\end{array}$ & $\mathrm{N} / \mathrm{C}$ & CP-08Jul1890 \\
\hline $\begin{array}{l}\text { Banda de Música dos menores do Club } \\
\text { Literário da Vila de Santo Amaro }\end{array}$ & $\mathrm{N} / \mathrm{C}$ & CP-30Dez1890 \\
\hline $\begin{array}{l}\text { Banda de Música italiana Giuseppe } \\
\text { Garibaldi }\end{array}$ & $\mathrm{N} / \mathrm{C}$ & OESP-17Jan1892 \\
\hline Banda de Música Giuseppe Verdi & $\mathrm{N} / \mathrm{C}$ & OESP-12Out1892 \\
\hline Banda de Música Alemã & $\mathrm{N} / \mathrm{C}$ & CP-23Abr1891 \\
\hline Banda de Música Alemã Guilherme II & $\mathrm{N} / \mathrm{C}$ & CP-24Mai1892 \\
\hline Banda de Música da Vila de Pinheiros & Augusto Ramos de Medeiros & $\begin{array}{c}\text { OESP-26Jan1902 } \\
\text { CP-12Jun1902 }\end{array}$ \\
\hline
\end{tabular}




\begin{tabular}{|c|c|c|}
\hline $\begin{array}{l}\text { Banda de Música Sociedade Ettore } \\
\text { Fieramosca }\end{array}$ & Maestro Puglieli & $\begin{array}{l}\text { OESP-15Mar1902 } \\
\text { OESP-17Abr1903 }\end{array}$ \\
\hline $\begin{array}{l}\text { Banda de Música da Sociedade Musical } \\
\text { Harmonia MBoense }\end{array}$ & Saturnino Canuto Gonçalves & CP-27Jan1902 \\
\hline $\begin{array}{l}\text { Banda de Música da Sociedade União } \\
\text { Internacional }\end{array}$ & $\mathrm{N} / \mathrm{C}$ & CP-18Mai1902 \\
\hline $\begin{array}{l}\text { Banda de Música Unione Meridionalle do } \\
\text { Braz }\end{array}$ & Jervolino Henrique & $\begin{array}{c}\text { CP-28Jun1902 } \\
\text { OESP-22Jul1903 }\end{array}$ \\
\hline $\begin{array}{l}\text { Banda de Música da Sociedade } \\
\text { Humanitária Cruz Verde }\end{array}$ & José Delaporta & CP-12Mar1903 \\
\hline $\begin{array}{l}\text { Banda de Música Princesa Mafalda di } \\
\text { Savóia }\end{array}$ & $\mathrm{N} / \mathrm{C}$ & CP-06Abr1903 \\
\hline Banda de Música Euterpe Commercial & $\mathrm{N} / \mathrm{C}$ & $\begin{array}{c}\text { Antônio Egydio } \\
\text { Martins. São Paulo } \\
\text { Antigo } 1554 \text { a } 1910 \text { p.205 }\end{array}$ \\
\hline Banda de Música Luzitana Portugueza & $\mathrm{N} / \mathrm{C}$ & OESP-24Jun1906 \\
\hline Banda de Música Luzitana do Braz & Avelino Monteiro Alves & $\begin{array}{l}\text { OESP-02Mai1910 } \\
\text { OESP-20Jun1910 }\end{array}$ \\
\hline $\begin{array}{l}\text { Banda de Música União Operária da Lapa } \\
\text { Banda Musical Quinze de novembro da } \\
\text { Lapa }\end{array}$ & Victor Arrigo & $\begin{array}{l}\text { OESP-03Mai1910 } \\
\text { OESP-16Nov1910 }\end{array}$ \\
\hline $\begin{array}{l}\text { Banda de Música do Club de Tiro } \\
\text { Brasileiro nº } 34 \text { - Linha Coronel Pedroso }\end{array}$ & $\begin{array}{l}2^{\circ} \text { Tenente Antônio } \\
\text { Galluzzio }\end{array}$ & OESP-24Jul1910 \\
\hline $\begin{array}{l}\text { Banda de Música do Clube de Tiro } \\
\text { brasileiro } N^{\circ} 35\end{array}$ & José Gaguione & $\begin{array}{l}\text { OESP-16Nov1910 } \\
\text { OESP-20Nov1910 }\end{array}$ \\
\hline Banda da Vidraria Santa Marina & Maestro Valeriani & HARMANN p. 65 \\
\hline Banda Musical Pietro Mascagni & Ângelo Amarante & OESP-01Jan1912 \\
\hline $\begin{array}{l}\text { Banda de Música da Associação Protetora } \\
\text { da Infância Desvalida }\end{array}$ & $\mathrm{N} / \mathrm{C}$ & OESP-26Jan1912 \\
\hline $\begin{array}{l}\text { Banda de Música Ítalo brasileira do Bom } \\
\text { Retiro }\end{array}$ & $\mathrm{N} / \mathrm{C}$ & OESP-07Jun1915 \\
\hline $\begin{array}{l}\text { Banda de Música da Associação Feminina } \\
\text { Beneficente e Instructiva }\end{array}$ & $\mathrm{N} / \mathrm{C}$ & OESP-18Dez1915 \\
\hline $\begin{array}{l}\text { Banda de Música Unione Meridionalle do } \\
\text { Bom Retiro }\end{array}$ & $\mathrm{N} / \mathrm{C}$ & OESP-12Nov1903 \\
\hline $\begin{array}{l}\text { Banda de Música da Sociedade Italiana di } \\
\text { Mútuo Sorcoso }\end{array}$ & $\mathrm{N} / \mathrm{C}$ & $\begin{array}{r}\text { Almanach Hist. Lit. } \\
\text { de São Paulo, } 1903 \text { p.208 }\end{array}$ \\
\hline
\end{tabular}




\begin{tabular}{|c|c|c|}
\hline $\begin{array}{l}\text { Banda de Música Internacional da } \\
\text { Sociedade Recreativa da Mooca }\end{array}$ & Libório Passaro & OESP-05Mai1902 \\
\hline $\begin{array}{l}\text { Banda de Música União Republicana do } \\
\text { Braz }\end{array}$ & Libório Passaro & OESP-14Nov1902 \\
\hline Banda de Música União Paulista & $\mathrm{N} / \mathrm{C}$ & OESP-13Mai1903 \\
\hline $\begin{array}{l}\text { Banda de Música da União Catholica de } \\
\text { Santo Agostinho }\end{array}$ & $\mathrm{N} / \mathrm{C}$ & OESP-24Jun1903 \\
\hline \multicolumn{3}{|c|}{ Bandas Indefinidas } \\
\hline Banda de Música 28 de Setembro & $\mathrm{N} / \mathrm{C}$ & OESP-19Jan1889 \\
\hline Banda de Música 7 de abril & $\mathrm{N} / \mathrm{C}$ & OESP-25Fev1890 \\
\hline S/I & Oliveira de Souza e Leite & CP-01Nov1888 \\
\hline $\mathrm{S} / \mathrm{I}$ & Vicente de Araújo & OESP-07Jun1890 \\
\hline $\mathrm{S} / \mathrm{I}$ & $\begin{array}{l}\text { Zelesino Augusto } \\
\text { Damasceno }\end{array}$ & CP-24Jul1890 \\
\hline $\mathrm{S} / \mathrm{I}$ & Sr. Paschoal & CP-29Dez1891 \\
\hline $\mathrm{S} / \mathrm{I}$ & Luiz Forly & OESP-26Jan1902 \\
\hline $\mathrm{S} / \mathrm{I}$ & Maestro Carrapatine & OESP-15Mai1912 \\
\hline Banda de Música 16 de Julho & Jordão de Senne & OESP-20Mar1902 \\
\hline Banda Philarmônica Paulista & Patrício Soares & OESP-02Jun1903 \\
\hline Banda Musical Carlos Gomes & Synesio Melchiades & OESP-14Mar1906 \\
\hline Banda de Música Alferes Lúcio & $\mathrm{N} / \mathrm{C}$ & OESP-06Mai1906 \\
\hline Banda de Música Restauração & $\mathrm{N} / \mathrm{C}$ & OESP-02Mai1910 \\
\hline Banda de Música Vincenzo Bellini & $\mathrm{N} / \mathrm{C}$ & OESP-16Ago1910 \\
\hline $\begin{array}{l}\text { Banda de Música Sant'Annense (de } \\
\text { Santana) }\end{array}$ & $\mathrm{N} / \mathrm{C}$ & OESP-18Jul1915 \\
\hline Banda de Música São Geraldo (da Penha) & $\mathrm{N} / \mathrm{C}$ & OESP-05Set1915 \\
\hline \multicolumn{3}{|c|}{ Bandas Militares } \\
\hline $\begin{array}{l}\text { Banda de Música da Guarda Municipal } \\
\text { Permanente/ Corpo de Policiais } \\
\text { Permanentes/ Força Policial/ Força } \\
\text { Pública do Estado de São Paulo }\end{array}$ & $\begin{array}{l}\text { Caetano Tibúrcio Rosa } \\
\text { Bernardo Jorge da Costa } \\
\text { Joaquim Antão Fernandes } \\
\text { Benedicto Assis de Lorena } \\
\text { Salvador Chiarelli } \\
\text { Joaquim Antão Fernandes } \\
\text { José Machado }\end{array}$ & $\begin{array}{l}\text { OESP-07Jan1889 } \\
\text { OESP-26Out1902. }\end{array}$ \\
\hline
\end{tabular}




\begin{tabular}{|c|c|c|}
\hline $\begin{array}{l}\text { Banda de Música do } 3^{\circ} \text { Batalhão de } \\
\text { Polícia }\end{array}$ & $\mathrm{N} / \mathrm{C}$ & $\begin{array}{l}\text { Janice Gonçalves } \\
\text { p. } 210\end{array}$ \\
\hline $\begin{array}{l}\text { Banda de Música do } 5^{\circ} \text { Batalhão de } \\
\text { Polícia }\end{array}$ & $\begin{array}{l}\text { Joaquim Antão Fernandes } \\
\text { até } 1895\end{array}$ & $\begin{array}{l}\text { Janice Gonçalves } \\
\text { p. } 210\end{array}$ \\
\hline $\begin{array}{l}\text { Banda de Música do } 10^{\circ} \text { Regimento de } \\
\text { Cavalaria do EB }\end{array}$ & $\begin{array}{l}\text { Ten. Gasparino de Castro } \\
\text { Carneiro Leão }\end{array}$ & $\begin{array}{l}\text { OESP 15Out1889 } \\
\text { OESP 08Jan1892 }\end{array}$ \\
\hline $\begin{array}{l}\text { Banda de Música do } 17^{\circ} \text { Batalhão de } \\
\text { Infantaria do EB }\end{array}$ & $\mathrm{N} / \mathrm{C}$ & CP-09Fev1888 \\
\hline $\begin{array}{l}\text { Banda de Música do } 7^{\circ} \text { Batalhão de } \\
\text { Voluntários Paulistas }\end{array}$ & $\mathrm{N} / \mathrm{C}$ & CP-30Mai1888 \\
\hline $\begin{array}{l}\text { Banda de Música do } 164^{\circ} \text { Batalhão de } \\
\text { Infantaria da Guarda Nacional }\end{array}$ & $\begin{array}{l}\text { Tenente Veríssimo A. Da } \\
\text { Glória }\end{array}$ & CP-18Jan1902 \\
\hline $\begin{array}{l}\text { Banda de Música da } 66^{\text {a }} \text { Brigada de } \\
\text { Infantaria da Guarda Nacional }\end{array}$ & $\mathrm{N} / \mathrm{C}$ & CP-19Jun1902 \\
\hline $\begin{array}{l}\text { Banda de Música da Guarda Nacional do } \\
\text { Braz }\end{array}$ & $\mathrm{N} / \mathrm{C}$ & OESP-08Mar1903 \\
\hline $\begin{array}{l}\text { Banda de Música do } 2^{\circ} \text { Batalhão da } \\
\text { Guarda Nacional }\end{array}$ & $\mathrm{N} / \mathrm{C}$ & OESP-21Abr1906 \\
\hline $\begin{array}{l}\text { Banda de Música do } 9^{\circ} \text { Batalhão } \\
\text { Infantaria da Guarda Nacional }\end{array}$ & Tenente Veríssimo da Glória & OESP-08Nov1910 \\
\hline $\begin{array}{l}\text { Banda de Música do Corpo de Bombeiros } \\
\text { do Est. de S. Paulo }\end{array}$ & Tenente Salvador Chiarelli & $\begin{array}{l}\text { Almanach Hist. Lit. } \\
\text { SP. 01Jan1895 p.281 }\end{array}$ \\
\hline $\begin{array}{l}\text { Banda de Música da Guarda Civil de São } \\
\text { Paulo }\end{array}$ & $\begin{array}{l}\text { Miguel de Marca } \\
\text { Carlos Lombardi }\end{array}$ & $\begin{array}{l}\text { DELLA MONICA, } \\
\text { Laura. pp.72-74 }\end{array}$ \\
\hline \multicolumn{3}{|c|}{ Bandas Escolares } \\
\hline $\begin{array}{l}\text { Banda de Música do Lyceu do Coração de } \\
\text { Jesus (Salesianos) }\end{array}$ & $\mathrm{N} / \mathrm{C}$ & OESP 27Nov1889 \\
\hline $\begin{array}{l}\text { Banda de Música da escola italiana } \\
\text { Avante Savóia }\end{array}$ & $\mathrm{N} / \mathrm{C}$ & OESP-29Jul1892 \\
\hline $\begin{array}{l}\text { Banda de Música do Lyceo de Artes e } \\
\text { Offícios }\end{array}$ & $\mathrm{N} / \mathrm{C}$ & OESP-04Jul1891 \\
\hline $\begin{array}{l}\text { Banda de Música do Collégio Atheneu } \\
\text { Paulista (alunos) }\end{array}$ & $\mathrm{N} / \mathrm{C}$ & OESP-29Jul1892 \\
\hline $\begin{array}{l}\text { Banda de Música do Orphanato } \\
\text { Christovam Colombo }\end{array}$ & Joaquim Capocchi & OESP-09Set1902 \\
\hline
\end{tabular}




\begin{tabular}{|c|c|c|}
\hline $\begin{array}{l}\text { Banda de Música do Seminário Episcopal } \\
\text { de São Paulo }\end{array}$ & $\mathrm{N} / \mathrm{C}$ & OESP-06Nov1902 \\
\hline Banda de Música do Instituto Profissional & Maestro Carlos & CP-17Abr1902 \\
\hline $\begin{array}{l}\text { Banda de Música do Instituto de Ensino } \\
\text { Dona Anna Rosa }\end{array}$ & $\mathrm{N} / \mathrm{C}$ & OESP-23Dez1903 \\
\hline \multicolumn{3}{|c|}{ Bandas de companhias, de circos e de carnaval } \\
\hline $\begin{array}{l}\text { *Banda de Música da Companhia } \\
\text { Equestre }\end{array}$ & $\mathrm{N} / \mathrm{C}$ & OESP-09Mar1889 \\
\hline $\begin{array}{l}\text { Banda de Música da Companhia do Sr. } \\
\text { Albano Pereira }\end{array}$ & Albano Pereira & CP-13Abr1890 \\
\hline $\begin{array}{l}\text { Banda de Música da Companhia de } \\
\text { Cavalinhos }\end{array}$ & $\mathrm{N} / \mathrm{C}$ & CP-27Jun 1890 \\
\hline Banda de Música da Companhia Ferrari & Guglielmo Bellucci & CP-13Ago1892 \\
\hline $\begin{array}{l}\text { Banda de Música de Carnaval Gatos } \\
\text { pretos }\end{array}$ & $\mathrm{N} / \mathrm{C}$ & CP-09Fev1902 \\
\hline Banda de Música da Companhia Spinelli & Francisco Castro & OESP-28Mar1903 \\
\hline Banda de Música do Circo Salvini & $\mathrm{N} / \mathrm{C}$ & OESP-06Abr1903 \\
\hline Banda de carnaval & Libório Passaro & OESP-30Jan1910 \\
\hline \multicolumn{3}{|c|}{ Bandas de teatros } \\
\hline Banda de Música do Frontão Boa Vista & $\mathrm{N} / \mathrm{C}$ & OESP-03Set1910 \\
\hline $\begin{array}{l}\text { Banda de Música Excêntricos do Teatro } \\
\text { Polytheama do Braz }\end{array}$ & $\mathrm{N} / \mathrm{C}$ & $\begin{array}{l}\text { BOSI, Eclea; Memória e } \\
\text { sociedade. Companhia } \\
\text { das Letras, São Paulo: } \\
2009 \text { p.147 }\end{array}$ \\
\hline
\end{tabular}

Legenda:

OESP - O Estado de São Paulo

$\mathrm{CP}$ - Correio Paulistano

N/C - Não consta (não foi possível identificar o nome do maestro)

S/I - Sem identificação (não foi possível identificar o nome da Banda)

* Companhia Equestre indefinida. 
Tabela 17

Comandantes e maestros da Banda de Música da Força Pública do Estado de São Paulo

\begin{tabular}{|c|c|c|c|}
\hline \multicolumn{4}{|c|}{$\begin{array}{l}\text { BANDA de MÚSICA DA FORÇA PÚBLICA do ESTADO de SÃO PAULO } \\
\text { COMANDANTES/ MAESTROS }\end{array}$} \\
\hline Posto $^{420}$ & Nome & Início & Término \\
\hline Sargento & Augusto Pereira Cardoso Portugal ${ }^{421}$ & $1857(?)$ & $? ? ? ?$ \\
\hline Sargento & José Pinto Tavares ${ }^{422}$ & $1864(?)$ & $1880(?)$ \\
\hline Sargento & $\begin{array}{l}\text { Caetano Tibúrcio de Oliveira } \\
\text { Rosa }^{423}\end{array}$ & 1880 & 1890 \\
\hline Sargento & Bernardo Jorge da Costa ${ }^{424}$ & 1890 & 1895 \\
\hline Capitão & Joaquim Antão Fernandes ${ }^{425}$ & 1895 & 1925 \\
\hline Capitão & Benedicto de Assis Lorena ${ }^{426}$ & 1925 & 1926 \\
\hline Capitão & Salvador Chiarelli ${ }^{427}$ & 1927 & 1931 \\
\hline Major & Joaquim Antão Fernandes ${ }^{428}$ & 1931 & 1932 \\
\hline Capitão & José Machado $^{429}$ & 1932 & 1939 \\
\hline Major & Antônio Romeu ${ }^{430}$ & 1939 & 1953 \\
\hline Major & Antônio Bento da Cunha ${ }^{431}$ & 1953 & 1955 \\
\hline Major & Alcides Jácomo Degobbi ${ }^{432}$ & 1956 & 1967 \\
\hline Major & Rubens Leonelli 433 & 1967 & 1980 \\
\hline Capitão & Nelson dos Santos & 1980 & 1983 \\
\hline Capitão & Francisco Cabrerisso & 1983 & 1984 \\
\hline Major & João Antão Fernandes & 1984 & 1990 \\
\hline
\end{tabular}

${ }^{420}$ Os postos referem-se ao último ocupado pelos respectivos maestros na ativa.

${ }^{421}$ AUGUSTO Portugal. O Estado de São Paulo, São Paulo, 29 out. 1891 p.1.

422 DELla MONICA, Laura. História da Banda de Música da Polícia Militar do Estado de São Paulo. 2. ed. São Paulo: Edanee, 1975, p. 30.

${ }^{423}$ DELLA MONICA, Laura. História da Banda de Música da Polícia Militar do Estado de São Paulo. 2. ed. São Paulo: Edanee, 1975, p.37; MELLONE, Dirceu Jair. Corpo Musical. Arte e profissão. Monografia apresentada ao CAO/I-86. São Paulo: PMESP, 1986 p.20.

${ }^{424}$ DELLA MONICA, Laura. História da Banda de Música da Polícia Militar do Estado de São Paulo. 2. ed. São Paulo: Edanee, 1975, p. 41

${ }^{425}$ DELla MONICA, Laura. História da Banda de Música da Polícia Militar do Estado de São Paulo. 2. ed. São Paulo: Edanee, 1975, p. 43

${ }^{426}$ Força Pública do Estado de São Paulo. Boletim Geral, São Paulo, n.115, p.1002, 29 mai. 1926.

${ }^{427}$ Força Pública do Estado de São Paulo. Boletim Geral, São Paulo, n.5, p.56, 7 jan.1931.

${ }^{428}$ Força Pública do Estado de São Paulo. Boletim Geral, São Paulo, n.7, p.89, 9 jan. 1931; Força Pública do Estado de São Paulo. Boletim Geral, São Paulo, n.9, p.67, 1 jan. 1932.

${ }^{429}$ DELlA MONICA, Laura. História da Banda de Música da Polícia Militar do Estado de São Paulo. 2. ed. São Paulo: Edanee, 1975, p.74.

${ }^{430}$ DELLA MONICA, Laura. História da Banda de Música da Polícia Militar do Estado de São Paulo. 2. ed. São Paulo: Edanee, 1975, p.79.

${ }^{431}$ DELLA MONICA, Laura. História da Banda de Música da Polícia Militar do Estado de São Paulo. 2. ed. São Paulo: Edanee, 1975, p.93.

432 DELlA MONICA, Laura. História da Banda de Música da Polícia Militar do Estado de São Paulo. 2. ed. São Paulo: Edanee, 1975, p. 96.

${ }^{433}$ Para Rubens Leonelli e os demais comandantes e maestros, Administração de Pessoal do Corpo Musical da Polícia Militar do Estado de São Paulo. 


\begin{tabular}{|l|l|l|l|}
\hline Major & Antônio Domingos Sacco & 1990 & 1991 \\
\hline Major & Rodolfo Cosignani & 1991 & 1994 \\
\hline Major & Roberto Vendramini & 1994 & 1997 \\
\hline Major & Antônio Carlos Martins Fernandes & 1997 & 2006 \\
\hline Major & Jonas Vicente de Oliveira & 2006 & 2009 \\
\hline Major & Renato Maximiano da Silva & 2009 & 2014 \\
\hline Major & Ezequiel Alves da Silva & 2014 & 2015 \\
\hline Major & Elias Batista do Nascimento & 2015 & 2018 \\
\hline Major & Clébio de Azevedo & 2018 & atual \\
\hline
\end{tabular}


Tabela 18

Discografia das bandas de música civis - cidade de São Paulo (1902-1932)

\begin{tabular}{|c|c|c|c|c|}
\hline \multicolumn{5}{|c|}{$\begin{array}{c}\text { BANDAS CIVIS DE SÃO PAULO } \\
\text { DISCOGRAFIA 1902-1932 }\end{array}$} \\
\hline $\begin{array}{l}\mathrm{N}^{\circ} \text { do } \\
\text { rótulo }\end{array}$ & Repertório & Gênero & Gravadora & $\begin{array}{l}\text { Autor - data } \\
\text { gravação }\end{array}$ \\
\hline $\begin{array}{l}* 108396 \\
\text { Disco } 27 \mathrm{~cm} \\
78 \mathrm{rpm}\end{array}$ & $\begin{array}{l}\text { Banda do Maestro Veríssimo } \\
\text { Lágrimas do Batista }\end{array}$ & Valsa & ODEON & $\begin{array}{l}1909 \\
? ? ? ?\end{array}$ \\
\hline $\begin{array}{l}108397 \\
\text { Disco } 27 \mathrm{~cm} \\
78 \mathrm{rpm}\end{array}$ & $\begin{array}{l}\text { Banda do Maestro Veríssimo } \\
\text { Escovadinha }\end{array}$ & Valsa & ODEON & $\begin{array}{l}1909 \\
? ? ? ?\end{array}$ \\
\hline $\begin{array}{l}108398 \\
\text { Disco } 27 \mathrm{~cm} \\
78 \mathrm{rpm}\end{array}$ & $\begin{array}{l}\text { Banda do Maestro Veríssimo } \\
\text { Partida para Canudos }\end{array}$ & Polca & ODEON & $\begin{array}{l}1909 \\
? ? ? ?\end{array}$ \\
\hline $\begin{array}{l}108400 \\
\text { Disco } 27 \mathrm{~cm} \\
78 \mathrm{rpm}\end{array}$ & $\begin{array}{l}\text { Banda do Maestro Veríssimo } \\
\text { Não faça assim }\end{array}$ & Choro & ODEON & $\begin{array}{l}1909 \\
? ? ? ?\end{array}$ \\
\hline $\begin{array}{l}108401 \\
\text { Disco } 27 \mathrm{~cm} \\
78 \mathrm{rpm}\end{array}$ & $\begin{array}{l}\text { Banda do Maestro Veríssimo } \\
\text { Campineiro }\end{array}$ & Maxixe & ODEON & $\begin{array}{l}1909 \\
? ? ? ?\end{array}$ \\
\hline $\begin{array}{l}108402 \\
\text { Disco } 27 \mathrm{~cm} \\
78 \mathrm{rpm}\end{array}$ & $\begin{array}{l}\text { Banda do Maestro Veríssimo } \\
\text { O choro }\end{array}$ & Dobrado & ODEON & $\begin{array}{l}1909 \\
? ? ? ?\end{array}$ \\
\hline $\begin{array}{l}108403 \\
\text { Disco } 27 \mathrm{~cm} \\
78 \mathrm{rpm}\end{array}$ & $\begin{array}{l}\text { Banda do Maestro Veríssimo } \\
\text { Deus e pátria }\end{array}$ & Dobrado & ODEON & $\begin{array}{l}1909 \\
? ? ? ?\end{array}$ \\
\hline $\begin{array}{l}108404 \\
\text { Disco } 27 \mathrm{~cm} \\
78 \mathrm{rpm}\end{array}$ & $\begin{array}{l}\text { Banda do Maestro Veríssimo } \\
\text { Suspenda o pranto }\end{array}$ & Polca & ODEON & $\begin{array}{l}1909 \\
? ? ? ?\end{array}$ \\
\hline $\begin{array}{l}108407 \\
\text { Disco } 27 \mathrm{~cm} \\
78 \mathrm{rpm}\end{array}$ & $\begin{array}{l}\text { Banda do Maestro Veríssimo } \\
\text { Lauro Sodré }\end{array}$ & Dobrado & ODEON & $\begin{array}{l}1909 \\
? ? ? ?\end{array}$ \\
\hline $\begin{array}{l}108408 \\
\text { Disco } 27 \mathrm{~cm} \\
78 \mathrm{rpm}\end{array}$ & $\begin{array}{l}\text { Banda do Maestro Veríssimo } \\
\text { Sou faceira }\end{array}$ & Tango & ODEON & $\begin{array}{l}1909 \\
? ? ? ?\end{array}$ \\
\hline $\begin{array}{l}108443 \\
\text { Disco } 27 \mathrm{~cm} \\
78 \mathrm{rpm}\end{array}$ & $\begin{array}{l}\text { Banda Ettore Fieramosca } \\
\text { La morena }\end{array}$ & Dobrado & ODEON & $\begin{array}{l}1909 \\
? ? ? ?\end{array}$ \\
\hline $\begin{array}{l}108444 \\
\text { Disco } 27 \mathrm{~cm} \\
78 \mathrm{rpm}\end{array}$ & $\begin{array}{l}\text { Banda Ettore Fieramosca } \\
\text { Los toreros }\end{array}$ & Dobrado & ODEON & $\begin{array}{l}1909 \\
? ? ? ?\end{array}$ \\
\hline $\begin{array}{l}108445 \\
\text { Disco } 27 \mathrm{~cm} \\
78 \mathrm{rpm}\end{array}$ & $\begin{array}{l}\text { Banda Ettore Fieramosca } \\
\text { São Paulo }\end{array}$ & Marcha & ODEON & $\begin{array}{l}1909 \\
? ? ? ?\end{array}$ \\
\hline $\begin{array}{l}108446 \\
\text { Disco } 27 \mathrm{~cm} \\
78 \mathrm{rpm}\end{array}$ & $\begin{array}{l}\text { Banda Ettore Fieramosca } \\
\text { Carmella mia }\end{array}$ & Marcha & ODEON & $\begin{array}{l}1909 \\
? ? ? ?\end{array}$ \\
\hline $\begin{array}{l}108449 \\
\text { Disco } 27 \mathrm{~cm} \\
78 \mathrm{rpm}\end{array}$ & $\begin{array}{l}\text { Banda Ettore Fieramosca } \\
\text { Esperia }\end{array}$ & Tango & ODEON & $\begin{array}{l}1909 \\
? ? ? ?\end{array}$ \\
\hline $\begin{array}{l}108455 \\
\text { Disco } 27 \mathrm{~cm}\end{array}$ & $\begin{array}{l}\text { Banda Ettore Fieramosca } \\
\text { Paulistinha }\end{array}$ & Schottisch & ODEON & $\begin{array}{l}1909 \\
? ? ? ?\end{array}$ \\
\hline
\end{tabular}




\begin{tabular}{|c|c|c|c|c|}
\hline $78 \mathrm{rpm}$ & & & & \\
\hline $\begin{array}{l}108456 \\
\text { Disco } 27 \mathrm{~cm} \\
78 \mathrm{rpm}\end{array}$ & $\begin{array}{l}\text { Banda Ettore Fieramosca } \\
\text { Desfolhando rosas }\end{array}$ & Schottisch & ODEON & $\begin{array}{l}1909 \\
? ? ? ?\end{array}$ \\
\hline $\begin{array}{l}108460 \\
\text { Disco } 27 \mathrm{~cm} \\
78 \mathrm{rpm}\end{array}$ & $\begin{array}{l}\text { Banda Ettore Fieramosca } \\
\text { Minha querida }\end{array}$ & Mazurca & ODEON & $\begin{array}{l}1909 \\
? ? ? ?\end{array}$ \\
\hline $\begin{array}{l}108461 \\
\text { Disco } 27 \mathrm{~cm} \\
78 \mathrm{rpm}\end{array}$ & $\begin{array}{l}\text { Banda Ettore Fieramosca } \\
\text { Felicidade desejada }\end{array}$ & Mazurca & ODEON & $\begin{array}{l}1909 \\
? ? ? ?\end{array}$ \\
\hline $\begin{array}{l}108463 \\
\text { Disco } 27 \mathrm{~cm} \\
78 \mathrm{rpm}\end{array}$ & $\begin{array}{l}\text { Banda Ettore Fieramosca } \\
\text { Sonho perigoso }\end{array}$ & Valsa & ODEON & $\begin{array}{l}1909 \\
? ? ? ?\end{array}$ \\
\hline $\begin{array}{l}120638 \\
\text { Disco } 27 \mathrm{~cm} \\
78 \mathrm{rpm}\end{array}$ & $\begin{array}{l}\text { Tudo dansa } \\
92\end{array}$ & $\begin{array}{l}\text { Polka } \\
\text { Dobrado }\end{array}$ & ODEON & $\begin{array}{l}\text { Junho } 1913 \\
\text { N. Glória } \\
\text { N. Glória }\end{array}$ \\
\hline $\begin{array}{l}120639 \\
\text { Disco } 27 \mathrm{~cm} \\
78 \mathrm{rpm}\end{array}$ & $\begin{array}{l}\text { Os Viannas } \\
\text { Quanto dóe uma saudade }\end{array}$ & $\begin{array}{l}\text { Tango } \\
\text { Valsa }\end{array}$ & ODEON & $\begin{array}{l}\text { Junho } 1913 \\
\text { N. Glória } \\
\text { N. Glória }\end{array}$ \\
\hline $\begin{array}{l}120641 \\
\text { Disco } 27 \mathrm{~cm} \\
78 \mathrm{rpm}\end{array}$ & $\begin{array}{l}\text { Banda Veríssimo Glória } \\
\text { Saudades de Alice }\end{array}$ & $? ? ? ?$ & ODEON & $\begin{array}{c}\text { Junho } 1913 \\
? ? ? ?\end{array}$ \\
\hline $\begin{array}{l}120642 \\
\text { Disco } 27 \mathrm{~cm} \\
78 \mathrm{rpm}\end{array}$ & $\begin{array}{l}\text { Izaltina } \\
\text { Otario }\end{array}$ & $\begin{array}{l}\text { Polka } \\
\text { Tango }\end{array}$ & ODEON & $\begin{array}{c}\text { Junho } 1913 \\
? ? ? ? \\
? ? ? ?\end{array}$ \\
\hline $\begin{array}{l}120643 \\
\text { Disco } 27 \mathrm{~cm} \\
78 \mathrm{rpm}\end{array}$ & $\begin{array}{l}\text { Banda Veríssimo Glória } \\
\text { Creoulo } \\
\text { Soberbo }\end{array}$ & $\begin{array}{l}\text { Tango } \\
\text { Valsa }\end{array}$ & ODEON & $\begin{array}{l}\text { Junho } 1913 \\
\text { L. Souza } \\
\text { L. Souza } \\
\end{array}$ \\
\hline $\begin{array}{l}120644 \\
\text { Disco } 27 \mathrm{~cm} \\
78 \mathrm{rpm}\end{array}$ & $\begin{array}{l}\text { Avenida Paulista } \\
\text { Toreador }\end{array}$ & $\begin{array}{l}\text { Polka- } \\
\text { tango } \\
\text { Valsa } \\
\end{array}$ & ODEON & $\begin{array}{l}\text { Junho } 1913 \\
\text { L. Souza } \\
\text { Leopoldo de } \\
\text { Souza } \\
\end{array}$ \\
\hline $\begin{array}{l}120645 \\
\text { Disco } 27 \mathrm{~cm} \\
78 \mathrm{rpm} \\
\end{array}$ & $\begin{array}{l}\text { O conscrito } \\
\text { Redea solta }\end{array}$ & $\begin{array}{l}\text { Dobrado } \\
\text { Maxixe }\end{array}$ & ODEON & $\begin{array}{l}\text { Junho } 1913 \\
\text { Otávio Dutra } \\
\text { Otávio Dutra } \\
\end{array}$ \\
\hline $\begin{array}{l}120646 \\
\text { Disco } 27 \mathrm{~cm} \\
78 \mathrm{rpm}\end{array}$ & $\begin{array}{l}\text { Caboclo } \\
\text { Ingenua }\end{array}$ & $\begin{array}{l}\text { Tango } \\
\text { Mazurka }\end{array}$ & ODEON & $\begin{array}{c}\text { Junho } 1913 \\
? ? ? ? \\
? ? ? ?\end{array}$ \\
\hline $\begin{array}{l}120647 \\
\text { Disco } 27 \mathrm{~cm} \\
78 \mathrm{rpm} \\
\end{array}$ & $\begin{array}{l}\text { Didinha } \\
\text { Segredo }\end{array}$ & $\begin{array}{l}\text { Valsa } \\
\text { Schottisch }\end{array}$ & ODEON & $\begin{array}{c}\text { Junho } 1913 \\
\text { Ruriz } \\
? ? ? ? \\
\end{array}$ \\
\hline $\begin{array}{l}120650 \\
\text { Disco } 27 \mathrm{~cm} \\
78 \mathrm{rpm}\end{array}$ & $\begin{array}{l}\text { Chic-Club } \\
\text { Sonho da Itália }\end{array}$ & $\begin{array}{l}\text { Tango } \\
\text { Marcha }\end{array}$ & ODEON & $\begin{array}{c}\text { Junho } 1913 \\
\text { S. Vaz } \\
\text { ???? }\end{array}$ \\
\hline $\begin{array}{l}120651 \\
\text { Disco } 27 \mathrm{~cm} \\
78 \mathrm{rpm}\end{array}$ & $\begin{array}{l}\text { Banda Ettore Fieramosca } \\
\text { Noventa e dois }\end{array}$ & Dobrado & ODEON & $\begin{array}{l}\text { Junho } 1913 \\
\text { N. Glória }\end{array}$ \\
\hline $\begin{array}{l}120652 \\
\text { Disco } 27 \mathrm{~cm} \\
78 \mathrm{rpm}\end{array}$ & $\begin{array}{l}\text { Banda Ettore Fieramosca } \\
\text { Quanto dóe uma saudade }\end{array}$ & Valsa & ODEON & $\begin{array}{l}\text { Junho } 1913 \\
\text { N. Glória }\end{array}$ \\
\hline $\begin{array}{l}120653 \\
\text { Disco } 27 \mathrm{~cm} \\
78 \mathrm{rpm}\end{array}$ & $\begin{array}{l}\text { Banda Ettore Fieramosca } \\
\text { O Soberbo }\end{array}$ & Valsa & ODEON & $\begin{array}{c}\text { Junho } 1913 \\
\text { Leopoldo de } \\
\text { Souza }\end{array}$ \\
\hline
\end{tabular}




\begin{tabular}{|c|c|c|c|c|}
\hline $\begin{array}{l}120655 \\
\text { Disco } 27 \mathrm{~cm} \\
78 \mathrm{rpm}\end{array}$ & $\begin{array}{l}\text { Banda Ettore Fieramosca } \\
\text { Rédea solta }\end{array}$ & Maxixe & ODEON & $\begin{array}{l}\text { Junho } 1913 \\
\text { Otávio Dutra }\end{array}$ \\
\hline $\begin{array}{l}120657 \\
\text { Disco } 27 \mathrm{~cm} \\
78 \mathrm{rpm}\end{array}$ & $\begin{array}{l}\text { Banda Ettore Fieramosca } \\
\text { Otário }\end{array}$ & Tango & ODEON & $\begin{array}{c}\text { Junho } 1913 \\
\text { ???? }\end{array}$ \\
\hline $\begin{array}{l}120660 \\
\text { Disco } 27 \mathrm{~cm} \\
78 \mathrm{rpm}\end{array}$ & $\begin{array}{l}\text { Banda Ettore Fieramosca } \\
\text { Ingênua }\end{array}$ & Mazurca & ODEON & $\begin{array}{c}\text { Junho } 1913 \\
\text { ???? }\end{array}$ \\
\hline $\begin{array}{l}120661 \\
\text { Disco } 27 \mathrm{~cm} \\
78 \mathrm{rpm}\end{array}$ & $\begin{array}{l}\text { Banda Ettore Fieramosca } \\
\text { Segredo }\end{array}$ & Schottisch & ODEON & $\begin{array}{c}\text { Junho } 1913 \\
\text { ???? }\end{array}$ \\
\hline $\begin{array}{l}120662 \\
\text { Disco } 27 \mathrm{~cm} \\
78 \mathrm{rpm}\end{array}$ & $\begin{array}{l}\text { Banda Ettore Fieramosca } \\
\text { Sonho da Itália }\end{array}$ & Marcha & ODEON & $\begin{array}{c}\text { Junho } 1913 \\
\text { ???? }\end{array}$ \\
\hline $\begin{array}{l}3030 \\
\text { Disco } 10 " \\
78 \mathrm{rpm}\end{array}$ & $\begin{array}{l}\text { Banda Giuseppe Verdi de S. Paulo } \\
\text { Aos bons companheiros }\end{array}$ & Marcha & GAÚCHO & $\begin{array}{l}1916 \\
? ? ? ?\end{array}$ \\
\hline $\begin{array}{l}\text { 3030-A } \\
\text { Disco 10" } \\
78 \text { rpm }\end{array}$ & $\begin{array}{l}\text { Banda Giuseppe Verdi de S. Paulo } \\
\text { O vestido rasgado }\end{array}$ & Valsa & GAÚCHO & $\begin{array}{c}1916 \\
\text { Luiz Forlin }\end{array}$ \\
\hline $\begin{array}{l}045 \\
\text { Disco 10" } \\
78 \mathrm{rpm}\end{array}$ & $\begin{array}{l}\text { Banda Veríssimo Glória } \\
\text { Tanzinha }\end{array}$ & Schottisch & PHOENIX & $\begin{array}{l}\text { 1913-1920 } \\
\text { ???? }\end{array}$ \\
\hline $\begin{array}{l}4.047 \\
\text { Disco 10" } \\
78 \mathrm{rpm}\end{array}$ & $\begin{array}{l}\text { Banda Giuseppe Verdi de S. Paulo } \\
\text { Trianerias } \\
\text { Brasil Unido }\end{array}$ & $\begin{array}{l}\text { Marcha } \\
\text { Marcha }\end{array}$ & $\begin{array}{l}\text { ARTE- } \\
\text { PHONE }\end{array}$ & $\begin{array}{c}1932 \\
\text { N. N. } \\
\text { Luiz Forlin }\end{array}$ \\
\hline $\begin{array}{l}4.108 \\
\text { Disco } 10 " \\
78 \mathrm{rpm}\end{array}$ & $\begin{array}{l}\text { Banda Giuseppe Verdi de S. Paulo } \\
\text { Light e power. } \\
\text { A augusto Vince }\end{array}$ & $\begin{array}{l}\text { Marcha } \\
\text { Marcha }\end{array}$ & $\begin{array}{l}\text { ARTE- } \\
\text { PHONE }\end{array}$ & $\begin{array}{l}1932 \\
\text { Luiz Forlin } \\
\text { Luiz Forlin }\end{array}$ \\
\hline
\end{tabular}

Fontes para a Discografia das bandas civis

1. Lágrimas do Batista. SANTOS, Alcino; BARBALHO, Gracio; SEVERIANO, Jairo; AZEVEDO, Miguel Ângelo de (Nirez). Discografia brasileira 78 rpm - 1904 a 1964. v.1, Rio de Janeiro: FUNARTE, 1982. p. 97.

2. Escovadinha. Acervo discográfico de Miguel Braghioni.

3. Partida de Canudos. SANTOS, Alcino; BARBALHO, Gracio; SEVERIANO, Jairo; AZEVEDO, Miguel Ângelo de (Nirez). Discografia brasileira 78 rpm - 1904 a 1964. v.1, Rio de Janeiro: FUNARTE, 1982. p. 97.

4. Não faça assim. SANTOS, Alcino; BARBALHO, Gracio; SEVERIANO, Jairo; AZEVEDO, Miguel Ângelo de (Nirez). Discografia brasileira 78 rpm - 1904 a 1964. v.1, Rio de Janeiro: FUNARTE, 1982. p. 97. 
5. Campineiro. SANTOS, Alcino; BARBALHO, Gracio; SEVERIANO, Jairo; AZEVEDO, Miguel Ângelo de (Nirez). Discografia brasileira 78 rpm - 1904 a 1964. v.1, Rio de Janeiro: FUNARTE, 1982. p. 97.

6. O choro. SANTOS, Alcino; BARBALHO, Gracio; SEVERIANO, Jairo; AZEVEDO, Miguel Ângelo de (Nirez). Discografia brasileira 78 rpm - 1904 a 1964. v.1, Rio de Janeiro: FUNARTE, 1982. p. 97.

7. Deus e pátria. SANTOS, Alcino; BARBALHO, Gracio; SEVERIANO, Jairo; AZEVEDO, Miguel Ângelo de (Nirez). Discografia brasileira 78 rpm - 1904 a 1964. v.1, Rio de Janeiro: FUNARTE, 1982. p. 97.

8. Suspenda o pranto. SANTOS, Alcino; BARBALHO, Gracio; SEVERIANO, Jairo; AZEVEDO, Miguel Ângelo de (Nirez). Discografia brasileira 78 rpm - 1904 a 1964. v.1, Rio de Janeiro: FUNARTE, 1982. p. 97.

9. Lauro Sodré. SANTOS, Alcino; BARBALHO, Gracio; SEVERIANO, Jairo; AZEVEDO, Miguel Ângelo de (Nirez). Discografia brasileira 78 rpm - 1904 a 1964. v.1, Rio de Janeiro: FUNARTE, 1982. p. 97.

10. Sou faceira. SANTOS, Alcino; BARBALHO, Gracio; SEVERIANO, Jairo; AZEVEDO, Miguel Ângelo de (Nirez). Discografia brasileira 78 rpm - 1904 a 1964. v.1, Rio de Janeiro: FUNARTE, 1982. p. 97.

11. La morena. Acervo discográfico de Miguel Ângelo de Azevedo - Nirez - Fortaleza CE.

12. Los toreros. Acervo discográfico de Miguel Ângelo de Azevedo - Nirez - Fortaleza CE.

13. São Paulo. Acervo discográfico de Miguel Ângelo de Azevedo - Nirez - Fortaleza CE.

14. Carmela mia. Acervo discográfico de Miguel Braghioni.

15. Esperia. SANTOS, Alcino; BARBALHO, Gracio; SEVERIANO, Jairo; AZEVEDO, Miguel Ângelo de (Nirez). Discografia brasileira 78 rpm - 1904 a 1964. v.1, Rio de Janeiro: FUNARTE, 1982. p.99.

16. Paulistinha. SANTOS, Alcino; BARBALHO, Gracio; SEVERIANO, Jairo; AZEVEDO, Miguel Ângelo de (Nirez). Discografia brasileira 78 rpm - 1904 a 1964. v.1, Rio de Janeiro: FUNARTE, 1982. p. 99. 
17. Desfolhando rosas. SANTOS, Alcino; BARBALHO, Gracio; SEVERIANO, Jairo; AZEVEDO, Miguel Ângelo de (Nirez). Discografia brasileira 78 rpm - 1904 a 1964. v.1, Rio de Janeiro: FUNARTE, 1982. p. 99.

18. Minha querida. SANTOS, Alcino; BARBALHO, Gracio; SEVERIANO, Jairo; AZEVEDO, Miguel Ângelo de (Nirez). Discografia brasileira 78 rpm - 1904 a 1964. v.1, Rio de Janeiro: FUNARTE, 1982. p. 99.

19. Felicidade desejada. SANTOS, Alcino; BARBALHO, Gracio; SEVERIANO, Jairo; AZEVEDO, Miguel Ângelo de (Nirez). Discografia brasileira 78 rpm - 1904 a 1964. v.1, Rio de Janeiro: FUNARTE, 1982. p. 99.

20. Sonho perigoso. SANTOS, Alcino; BARBALHO, Gracio; SEVERIANO, Jairo; AZEVEDO, Miguel Ângelo de (Nirez). Discografia brasileira 78 rpm - 1904 a 1964. v.1, Rio de Janeiro: FUNARTE, 1982. p. 99.

21. Tudo dansa gravado pela Banda Veríssimo Glória e 92 gravado pela Banda Ettore Fieramosca. Acervo discográfico de Miguel Braghioni.

22. Os Viannas foi gravada pela Banda Veríssimo Glória e Quanto dóe uma saudade, pela Banda Ettore Fieramosca. FRANCESCHI, Humberto M. A Casa Edison e seu tempo. Rio de Janeiro: Sarapuí, 2002. p. 183.

23. Saudades de Alice. Acervo discográfico de Miguel Ângelo de Azevedo - Nirez Fortaleza CE.

24. Izaltina foi gravada pela Banda Veríssimo Glória e Otário pela Banda Ettore Fieramosca. FRANCESCHI, Humberto M. A Casa Edison e seu tempo. Rio de Janeiro: Sarapuí, 2002. p. 183.

25. Creoulo e Soberbo. FRANCESCHI, Humberto M. A Casa Edison e seu tempo. Rio de Janeiro: Sarapuí, 2002. p. 183.

26. Avenida Paulista foi gravada pela Banda Veríssimo Glória e Toreador foi gravada pela Banda Ettore Fieramosca. FRANCESCHI, Humberto M. A Casa Edison e seu tempo. Rio de Janeiro: Sarapuí, 2002. p. 183.

27. O conscripto foi gravado pela Banda Veríssimo Glória e Rédea solta foi gravada pela Banda Ettore Fieramosca. FRANCESCHI, Humberto M. A Casa Edison e seu tempo. Rio de Janeiro: Sarapuí, 2002. p. 180-183; SANTOS, Alcino; BARBALHO, Gracio; 
SEVERIANO, Jairo; AZEVEDO, Miguel Ângelo de (Nirez). Discografia brasileira 78 rpm - 1904 a 1964. v.1, Rio de Janeiro: FUNARTE, 1982. p. 155.

28. Caboclo foi gravada pela Banda Veríssimo Glória e Ingênua foi gravada pela Banda Ettore Fieramosca. FRANCESCHI, Humberto M. A Casa Edison e seu tempo. Rio de Janeiro: Sarapuí, 2002. p. 180-183; SANTOS, Alcino; BARBALHO, Gracio; SEVERIANO, Jairo; AZEVEDO, Miguel Ângelo de (Nirez). Discografia brasileira 78 rpm - 1904 a 1964. v.1, Rio de Janeiro: FUNARTE, 1982. p. 155.

29. Didinha foi gravada pela Banda Veríssimo Glória e Segredo foi gravada pela Banda Ettore Fieramosca. FRANCESCHI, Humberto M. A Casa Edison e seu tempo. Rio de Janeiro: Sarapuí, 2002. p. 180-183; SANTOS, Alcino; BARBALHO, Gracio; SEVERIANO, Jairo; AZEVEDO, Miguel Ângelo de (Nirez). Discografia brasileira 78 rpm - 1904 a 1964. v.1, Rio de Janeiro: FUNARTE, 1982. p. 155.

30. Chic-Club foi gravada pela Banda Veríssimo Glória e Sonho da Itália foi gravada pela Banda Ettore Fieramosca. FRANCESCHI, Humberto M. A Casa Edison e seu tempo. Rio de Janeiro: Sarapuí, 2002. p. 180-183; SANTOS, Alcino; BARBALHO, Gracio; SEVERIANO, Jairo; AZEVEDO, Miguel Ângelo de (Nirez). Discografia brasileira 78 rpm - 1904 a 1964. v.1, Rio de Janeiro: FUNARTE, 1982. p. 155.

31. Noventa e dois. FRANCESCHI, Humberto M. A Casa Edison e seu tempo. Rio de Janeiro: Sarapuí, 2002. p. 180-183; SANTOS, Alcino; BARBALHO, Gracio; SEVERIANO, Jairo; AZEVEDO, Miguel Ângelo de (Nirez). Discografia brasileira 78 rpm - 1904 a 1964. v.1, Rio de Janeiro: FUNARTE, 1982. p. 155.

32. Quanto dóe uma saudade. FRANCESCHI, Humberto M. A Casa Edison e seu tempo. Rio de Janeiro: Sarapuí, 2002. p. 180-183; SANTOS, Alcino; BARBALHO, Gracio; SEVERIANO, Jairo; AZEVEDO, Miguel Ângelo de (Nirez). Discografia brasileira 78 rpm - 1904 a 1964. v.1, Rio de Janeiro: FUNARTE, 1982. p. 155.

33. O soberbo. FRANCESCHI, Humberto M. A Casa Edison e seu tempo. Rio de Janeiro: Sarapuí, 2002. p. 180-183; SANTOS, Alcino; BARBALHO, Gracio; SEVERIANO, Jairo; AZEVEDO, Miguel Ângelo de (Nirez). Discografia brasileira 78 rpm - 1904 a 1964. v.1, Rio de Janeiro: FUNARTE, 1982. p. 155.

34. Rédea solta. FRANCESCHI, Humberto M. A Casa Edison e seu tempo. Rio de Janeiro: Sarapuí, 2002. p. 180-183; SANTOS, Alcino; BARBALHO, Gracio; SEVERIANO, 
Jairo; AZEVEDO, Miguel Ângelo de (Nirez). Discografia brasileira 78 rpm - 1904 a 1964. v.1, Rio de Janeiro: FUNARTE, 1982. p. 155.

35. Otário. FRANCESCHI, Humberto M. A Casa Edison e seu tempo. Rio de Janeiro: Sarapuí, 2002. p. 180-183; SANTOS, Alcino; BARBALHO, Gracio; SEVERIANO, Jairo; AZEVEDO, Miguel Ângelo de (Nirez). Discografia brasileira 78 rpm - 1904 a 1964. v.1, Rio de Janeiro: FUNARTE, 1982. p. 155.

36. Ingênua. FRANCESCHI, Humberto M. A Casa Edison e seu tempo. Rio de Janeiro: Sarapuí, 2002. p. 180-183; SANTOS, Alcino; BARBALHO, Gracio; SEVERIANO, Jairo; AZEVEDO, Miguel Ângelo de (Nirez). Discografia brasileira 78 rpm - 1904 a 1964. v.1, Rio de Janeiro: FUNARTE, 1982. p. 155.

37. Segredo. FRANCESCHI, Humberto M. A Casa Edison e seu tempo. Rio de Janeiro: Sarapuí, 2002. p. 180-183 e SANTOS, Alcino; BARBALHO, Gracio; SEVERIANO, Jairo; AZEVEDO, Miguel Ângelo de (Nirez). Discografia brasileira 78 rpm - 1904 a 1964. v.1, Rio de Janeiro: FUNARTE, 1982. p. 155.

38. Sonho da Itália. Acervo discográfico de Miguel Ângelo de Azevedo - Nirez Fortaleza CE.

39. Aos bons companheiros. Acervo discográfico de Miguel Ângelo de Azevedo - Nirez Fortaleza CE.

40. O vestido rasgado. Acervo discográfico de Miguel Ângelo de Azevedo - Nirez Fortaleza CE.

41. Tanzinha. Fundação Joaquim Nabuco. Base de dados discos de 78 rpm, Recife PE.

42. Trianeiras e Brasil unido. Acervo discográfico de Miguel Braghioni.

43. Light e power e A Augusto Vince. SANTOS, Alcino; BARBALHO, Gracio; SEVERIANO, Jairo; AZEVEDO, Miguel Ângelo de (Nirez). Discografia brasileira 78 rpm - 1904 a 1964. 5 v. Rio de Janeiro: FUNARTE, 1982. p. 465. 
Tabela 19

Discografia da Banda de Música da Força Pública do Estado de São Paulo (1902-1932)

\begin{tabular}{|c|c|c|c|c|}
\hline \multicolumn{5}{|c|}{$\begin{array}{c}\text { BANDA DA FORÇA POLICIAL / PÚBLICA DE SÃO PAULO } \\
\text { DISCOGRAFIA 1902-1932 }\end{array}$} \\
\hline $\mathrm{N}^{\circ}$ do rótulo & Repertório & Gênero & Gravadora & $\begin{array}{l}\text { Data gravação ou } \\
\text { lançamento/ Autor }\end{array}$ \\
\hline $\begin{array}{l}\text { X-729 } \\
\text { Disco 10" } \\
78 \mathrm{rpm}\end{array}$ & Feiticeira & Polca & $\begin{array}{l}\text { ZON-O- } \\
\text { PHONE }\end{array}$ & $\begin{array}{l}\text { c. } 1902-1903 \\
? ? ? ?\end{array}$ \\
\hline $\begin{array}{l}108409 \\
\text { Disco } 27 \mathrm{~cm} \\
78 \mathrm{rpm}\end{array}$ & Robinson Crusoé & Marcha & ODEON & $\begin{array}{l}1909 \\
? ? ? ?\end{array}$ \\
\hline $\begin{array}{l}108410 \\
\text { Disco } 27 \mathrm{~cm} \\
78 \mathrm{rpm}\end{array}$ & Viúva Alegre & Valsa & ODEON & $\begin{array}{l}1909 \\
\text { F. Lehar }\end{array}$ \\
\hline $\begin{array}{l}108411 \\
\text { Disco } 27 \mathrm{~cm} \\
78 \mathrm{rpm}\end{array}$ & Ao clarão da lua & Mazurca & ODEON & $\begin{array}{c}1909 \\
\text { Maestro Antão }\end{array}$ \\
\hline $\begin{array}{l}108412 \\
\text { Disco } 27 \mathrm{~cm} \\
78 \mathrm{rpm}\end{array}$ & Coalhada & Tango & ODEON & $\begin{array}{l}1909 \\
? ? ? ?\end{array}$ \\
\hline $\begin{array}{l}108415 \\
\text { Disco } 27 \mathrm{~cm} \\
78 \mathrm{rpm}\end{array}$ & $\begin{array}{l}\text { Momento musical de } \\
\text { Schubert }\end{array}$ & Valsa & ODEON & $\begin{array}{l}1909 \\
? ? ? ?\end{array}$ \\
\hline $\begin{array}{l}108417 \\
\text { Disco } 27 \mathrm{~cm} \\
78 \mathrm{rpm}\end{array}$ & Marcha dos Croatas & Marcha & ODEON & $\begin{array}{l}1909 \\
? ? ? ?\end{array}$ \\
\hline $\begin{array}{l}108418 \\
\text { Disco } 27 \mathrm{~cm} \\
78 \mathrm{rpm}\end{array}$ & Língua de Preto & Polca & ODEON & $\begin{array}{c}1909 \\
\text { Honorino Lopes }\end{array}$ \\
\hline $\begin{array}{l}108419 \\
\text { Disco } 27 \mathrm{~cm} \\
78 \text { RPM }\end{array}$ & Divina & Schottisch & ODEON & $\begin{array}{l}1909 \\
? ? ? ?\end{array}$ \\
\hline $\begin{array}{l}108421 \\
\text { Disco } 27 \mathrm{~cm} \\
78 \mathrm{rpm}\end{array}$ & $\begin{array}{l}\text { Valsa Lenta do } \\
\text { Maestro Osvaldo }\end{array}$ & Valsa & ODEON & $\begin{array}{c}1909 \\
\text { Maestro Osvaldo }\end{array}$ \\
\hline $\begin{array}{l}108423 \\
\text { Disco } 27 \mathrm{~cm} \\
78 \mathrm{rpm}\end{array}$ & Resposta a uma marcha & ???? & ODEON & $\begin{array}{l}1909 \\
? ? ? ?\end{array}$ \\
\hline $\begin{array}{l}108424 \\
\text { Disco } 27 \mathrm{~cm} \\
78 \mathrm{rpm}\end{array}$ & Atraído por uma flor & Valsa & ODEON & $\begin{array}{c}1909 \\
\text { Mestre Antão }\end{array}$ \\
\hline $\begin{array}{l}108426 \\
\text { Disco } 27 \mathrm{~cm} \\
78 \mathrm{rpm}\end{array}$ & Japonês & Dobrado & ODEON & $\begin{array}{c}1909 \\
\text { Luiz Silva }\end{array}$ \\
\hline $\begin{array}{l}108428 \\
\text { Disco } 27 \mathrm{~cm} \\
78 \mathrm{rpm}\end{array}$ & A três irmãos & Valsa & ODEON & $\begin{array}{l}1909 \\
? ? ? ?\end{array}$ \\
\hline $\begin{array}{l}108429 \\
\text { Disco } 27 \mathrm{~cm} \\
78 \mathrm{rpm}\end{array}$ & Tudinha & Polca & ODEON & $\begin{array}{l}1909 \\
? ? ? ?\end{array}$ \\
\hline $\begin{array}{l}108430 \\
\text { Disco } 27 \mathrm{~cm} \\
78 \mathrm{rpm}\end{array}$ & Amor Saudoso & Valsa & ODEON & $\begin{array}{l}1909 \\
? ? ? ?\end{array}$ \\
\hline 108431 & & & ODEON & 1909 \\
\hline
\end{tabular}




\begin{tabular}{|c|c|c|c|c|}
\hline $\begin{array}{l}\text { Disco } 27 \mathrm{~cm} \\
78 \mathrm{rpm}\end{array}$ & Titita & Mazurca & & $? ? ? ?$ \\
\hline $\begin{array}{l}108432 \\
\text { Disco } 27 \mathrm{~cm} \\
78 \mathrm{rpm}\end{array}$ & Dizem que sou bonita & Polca & ODEON & $\begin{array}{l}1909 \\
? ? ? ?\end{array}$ \\
\hline $\begin{array}{l}108433 \\
\text { Disco } 27 \mathrm{~cm} \\
78 \mathrm{rpm}\end{array}$ & Manuelita & Polca & ODEON & $\begin{array}{l}1909 \\
? ? ? ?\end{array}$ \\
\hline $\begin{array}{l}108434 \\
\text { Disco } 27 \mathrm{~cm} \\
78 \mathrm{rpm}\end{array}$ & Vem cá mulata & Tango & ODEON & $\begin{array}{c}1909 \\
\text { Arquimedes de Oliveira }\end{array}$ \\
\hline $\begin{array}{l}108436 \\
\text { Disco } 27 \mathrm{~cm} \\
78 \mathrm{rpm}\end{array}$ & Rio Branco & Dobrado & ODEON & $\begin{array}{l}1909 \\
? ? ? ?\end{array}$ \\
\hline $\begin{array}{l}108438 \\
\text { Disco } 27 \mathrm{~cm} \\
78 \mathrm{rpm}\end{array}$ & Uma recordação & Valsa & ODEON & $\begin{array}{l}1909 \\
? ? ? ?\end{array}$ \\
\hline $\begin{array}{l}108439 \\
\text { Disco } 27 \mathrm{~cm} \\
78 \mathrm{rpm} \\
\end{array}$ & Débora & Polca & ODEON & $\begin{array}{l}1909 \\
? ? ? ?\end{array}$ \\
\hline $\begin{array}{l}120640 \\
\text { Disco } 27 \mathrm{~cm} \\
78 \mathrm{rpm}\end{array}$ & $\begin{array}{l}\text { Belarmina } \\
\text { Mexicana }\end{array}$ & $\begin{array}{l}\text { Schottisch } \\
\text { Two-Step }\end{array}$ & ODEON & $\begin{array}{c}\text { Junho } 1913 \\
\text { N. Glória } \\
\text { ???? }\end{array}$ \\
\hline $\begin{array}{l}120648 \\
\text { Disco } 27 \mathrm{~cm} \\
78 \mathrm{rpm}\end{array}$ & $\begin{array}{l}\text { América } \\
\text { A vassourinha }\end{array}$ & $\begin{array}{l}\text { Mazurca } \\
\text { Polka }\end{array}$ & ODEON & $\begin{array}{c}\text { Junho } 1913 \\
\text { Francisco Americano } \\
\text { Felipe Duarte }\end{array}$ \\
\hline $\begin{array}{l}120649 \\
\text { Disco } 27 \mathrm{~cm} \\
78 \mathrm{rpm}\end{array}$ & $\begin{array}{l}\text { Valadino } \\
\text { Attrahído por uma flor }\end{array}$ & $\begin{array}{l}\text { Tango } \\
\text { Valsa }\end{array}$ & ODEON & $\begin{array}{c}\text { Junho } 1913 \\
\text { S. Vaz } \\
\text { Maestro Antão } \\
\end{array}$ \\
\hline $\begin{array}{l}120654 \\
\text { Disco } 27 \mathrm{~cm} \\
78 \mathrm{rpm}\end{array}$ & $\begin{array}{l}\text { Olhar tristonho } \\
\text { Pisando em Ovos }\end{array}$ & $\begin{array}{l}\text { Valsa } \\
\text { Tangaica } \\
\text { característica } \\
\end{array}$ & ODEON & $\begin{array}{c}\text { Junho } 1913 \\
\text { Carlos de Abreu } \\
? ? ? ?\end{array}$ \\
\hline $\begin{array}{l}120656 \\
\text { Disco } 27 \mathrm{~cm} \\
78 \mathrm{rpm}\end{array}$ & $\begin{array}{l}\text { O pauzinho } \\
\text { Gloriosa Banderia }\end{array}$ & $\begin{array}{l}\text { Maxixe } \\
\text { Marcha }\end{array}$ & ODEON & $\begin{array}{c}\text { Junho } 1913 \\
? ? ? ? \\
? ? ? ?\end{array}$ \\
\hline $\begin{array}{l}120658 \\
\text { Disco } 27 \mathrm{~cm} \\
78 \mathrm{rpm}\end{array}$ & $\begin{array}{l}\text { Bella chilena } \\
\text { O Maxixe - Revista }\end{array}$ & $\begin{array}{l}\text { Valsa } \\
\text { Maxixe }\end{array}$ & ODEON & $\begin{array}{c}\text { Junho } 1913 \\
\text { Ernesto Becucci } \\
\text { Grevista } \\
\end{array}$ \\
\hline $\begin{array}{l}120659 \\
\text { Disco } 27 \mathrm{~cm} \\
78 \mathrm{rpm}\end{array}$ & $\begin{array}{l}\text { Toscanina } \\
\text { Fremito d'Amor }\end{array}$ & $\begin{array}{l}\text { Mazurca } \\
\text { Valsa }\end{array}$ & ODEON & $\begin{array}{l}\text { Junho } 1913 \\
\text { ???? } \\
\text { A. Barbiroli }\end{array}$ \\
\hline $\begin{array}{l}120663 \\
\text { Disco } 27 \mathrm{~cm} \\
78 \mathrm{rpm}\end{array}$ & O maxixe & Maxixe & ODEON & $\begin{array}{c}\text { Junho } 1913 \\
\text { Grevista }\end{array}$ \\
\hline $\begin{array}{l}120664 \\
\text { Disco } 27 \mathrm{~cm} \\
78 \mathrm{rpm}\end{array}$ & Toreador & Valsa & ODEON & $\begin{array}{c}\text { Junho } 1913 \\
\text { ???? }\end{array}$ \\
\hline $\begin{array}{l}120665 \\
\text { Disco } 27 \mathrm{~cm} \\
78 \mathrm{rpm}\end{array}$ & A gloriosa Bandeira & Marcha & ODEON & $\begin{array}{c}\text { Junho } 1913 \\
\text { ???? }\end{array}$ \\
\hline $\begin{array}{l}120666 \\
\text { Disco } 27 \mathrm{~cm} \\
78 \mathrm{rpm}\end{array}$ & Fremito d'amore & Valsa & ODEON & $\begin{array}{l}\text { Junho } 1913 \\
\text { A. Barbiroli }\end{array}$ \\
\hline $\begin{array}{l}120667 \\
\text { Disco } 27 \mathrm{~cm}\end{array}$ & Pisando em ovos & Tangaica & ODEON & $\begin{array}{c}\text { Junho } 1913 \\
\text { Carlos de Abreu }\end{array}$ \\
\hline
\end{tabular}




\begin{tabular}{|l|l|l|c|c|}
\hline $78 \mathrm{rpm}$ & & & & \\
\hline $\begin{array}{l}120668 \\
\text { Disco } 27 \mathrm{~cm} \\
78 \mathrm{rpm}\end{array}$ & A vassourinha & Polca & ODEON & Junho 1913 \\
\hline $\begin{array}{l}120669 \\
\text { Disco } 27 \mathrm{~cm} \\
78 \mathrm{rpm}\end{array}$ & Atraído por uma flor & Valsa & ODEON & Junho 1913 \\
\hline $\begin{array}{l}120670 \\
\text { Disco } 27 \mathrm{~cm} \\
78 \mathrm{rpm}\end{array}$ & Mexicana & Two-Step & ODEON & Junho 1913 \\
\hline
\end{tabular}

Fontes para a Discografia da Banda da Força Pública do Estado de São Paulo

1. Feiticieira. Fundação Joaquim Nabuco. Base de dados discos de 78 rpm, Recife PE.

2. Robison Crusoé. Embora o trabalho de SANTOS, Alcino; BARBALHO, Gracio; SEVERIANO, Jairo; AZEVEDO, Miguel Ângelo de (Nirez). Discografia brasileira 78 rpm - 1904 a 1964. v.1, Rio de Janeiro: FUNARTE, 1982. p. 97 nos dê a informação de que o selo 108409 pertença à gravação de Marcha dos Croatas e o de numeração 108417 à gravação de Robinson Crusoé, em levantamento realizado na coleção de Miguel Braghioni, pôde-se verificar que os nomes e números estão possivelmente trocados. O correto, portanto, é como consta na presente tabela.

3. Viúva alegre. SANTOS, Alcino; BARBALHO, Gracio; SEVERIANO, Jairo; AZEVEDO, Miguel Ângelo de (Nirez). Discografia brasileira 78 rpm - 1904 a 1964. v.1, Rio de Janeiro: FUNARTE, 1982, p. 97.

4. Ao clarão da lua. Acervo discográfico de Miguel Ângelo de Azevedo - Nirez Fortaleza CE.

5. Coalhada. Acervo discográfico de Miguel Ângelo de Azevedo - Nirez - Fortaleza CE.

6. Momento musical de Schubert. Acervo discográfico de Miguel Ângelo de Azevedo Nirez - Fortaleza CE.

7. Marcha dos croatas. Acervo discográfico de Miguel Ângelo de Azevedo - Nirez Fortaleza CE.

8. Língua de preto. SANTOS, Alcino; BARBALHO, Gracio; SEVERIANO, Jairo; AZEVEDO, Miguel Ângelo de (Nirez). Discografia brasileira 78 rpm - 1904 a 1964. v.1, Rio de Janeiro: FUNARTE, 1982, p. 98.

9. Divina. Acervo discográfico de Miguel Ângelo de Azevedo - Nirez - Fortaleza CE. 
10. Valsa lenta do maestro Oswaldo. SANTOS, Alcino; BARBALHO, Gracio; SEVERIANO, Jairo; AZEVEDO, Miguel Ângelo de (Nirez). Discografia brasileira 78 rpm - 1904 a 1964. v.1, Rio de Janeiro: FUNARTE, 1982, p. 98.

11. Resposta a uma marcha. Acervo discográfico de Miguel Ângelo de Azevedo - Nirez Fortaleza CE.

12. Atraído por uma flor. Acervo discográfico de Miguel Ângelo de Azevedo - Nirez Fortaleza CE.

13. Japonês. SANTOS, Alcino; BARBALHO, Gracio; SEVERIANO, Jairo; AZEVEDO, Miguel Ângelo de (Nirez). Discografia brasileira 78 rpm - 1904 a 1964. v.1, Rio de Janeiro: FUNARTE, 1982, p. 98.

14. A três irmãos. SANTOS, Alcino; BARBALHO, Gracio; SEVERIANO, Jairo; AZEVEDO, Miguel Ângelo de (Nirez). Discografia brasileira 78 rpm - 1904 a 1964. v.1, Rio de Janeiro: FUNARTE, 1982, p. 98.

15. Tudinha. SANTOS, Alcino; BARBALHO, Gracio; SEVERIANO, Jairo; AZEVEDO, Miguel Ângelo de (Nirez). Discografia brasileira 78 rpm - 1904 a 1964. v.1, Rio de Janeiro: FUNARTE, 1982, p. 98.

16. Amor saudoso. SANTOS, Alcino; BARBALHO, Gracio; SEVERIANO, Jairo; AZEVEDO, Miguel Ângelo de (Nirez). Discografia brasileira 78 rpm - 1904 a 1964. v.1, Rio de Janeiro: FUNARTE, 1982, p. 98.

17. Titita. SANTOS, Alcino; BARBALHO, Gracio; SEVERIANO, Jairo; AZEVEDO, Miguel Ângelo de (Nirez). Discografia brasileira 78 rpm - 1904 a 1964. v.1, Rio de Janeiro: FUNARTE, 1982, p. 98.

18. Dizem que sou bonita. Acervo discográfico de Miguel Ângelo de Azevedo - Nirez Fortaleza CE.

19. Manuelita. SANTOS, Alcino; BARBALHO, Gracio; SEVERIANO, Jairo; AZEVEDO, Miguel Ângelo de (Nirez). Discografia brasileira 78 rpm - 1904 a 1964. v.1 Rio de Janeiro: FUNARTE, 1982, p. 98. Para a data da gravação: FRANCESCHI, Humberto M. A Casa Edison e seu tempo. Rio de Janeiro: Sarapuí, 2002. p. 180

20. Vem cá mulata. SANTOS, Alcino; BARBALHO, Gracio; SEVERIANO, Jairo; AZEVEDO, Miguel Ângelo de (Nirez). Discografia brasileira 78 rpm - 1904 a 1964. 
v.1, Rio de Janeiro: FUNARTE, 1982, p. 98. Para a data da gravação: FRANCESCHI, Humberto M. A Casa Edison e seu tempo. Rio de Janeiro: Sarapuí, 2002. pp. 180-183

21. Rio Branco. SANTOS, Alcino; BARBALHO, Gracio; SEVERIANO, Jairo; AZEVEDO, Miguel Ângelo de (Nirez). Discografia brasileira 78 rpm - 1904 a 1964. v.1, Rio de Janeiro: FUNARTE, 1982, p. 98. Para a data da gravação: FRANCESCHI, Humberto M. A Casa Edison e seu tempo. Rio de Janeiro: Sarapuí, 2002. p. 180.

22. Uma recordação. Acervo discográfico de Miguel Ângelo de Azevedo - Nirez Fortaleza CE.

23. Débora. Acervo discográfico de Miguel Ângelo de Azevedo - Nirez - Fortaleza CE.

24. Belarmina foi grava pela Banda Veríssimo Glória e Mexicana, foi gravada pela Banda da Força Pública. FRANCESCHI, Humberto M. A Casa Edison e seu tempo. Rio de Janeiro: Sarapuí, 2002. p. 183.

25. América foi gravada pela Banda Veríssimo Glória e A vassourinha, foi gravada pela Banda da Força Pública. FRANCESCHI, Humberto M. A Casa Edison e seu tempo. Rio de Janeiro: Sarapuí, 2002. p. 183.

26. Valadino foi gravada pela Banda Veríssimo Glória e Atraído por uma flor foi gravada pela Banda da Força Pública. FRANCESCHI, Humberto M. A Casa Edison e seu tempo. Rio de Janeiro: Sarapuí, 2002. p. 183.

27. Olhar tristonho foi gravado pela Banda Ettore Fieramosca e Pisando em ovos foi gravada pela Banda da Força Pública. FRANCESCHI, Humberto M. A Casa Edison e seu tempo. Rio de Janeiro: Sarapuí, 2002. p. 183.

28. O pauzinho foi gravado pela Banda Ettore Fieramosca e Gloriosa Bandeira foi gravada pela Banda da Força Pública. FRANCESCHI, Humberto M. A Casa Edison e seu tempo. Rio de Janeiro: Sarapuí, 2002. p. 183.

29. Bella chilena foi gravada pela Banda Ettore Fieramosca e O Maxixe - Revista, foi gravado pela Banda da Força Pública. FRANCESCHI, Humberto M. A Casa Edison e seu tempo. Rio de Janeiro: Sarapuí, 2002. p. 183.

30. Toscanina foi gravada pela Banda Ettore Fieramosca e Fremito d'amor foi gravada pela Banda da Força Pública. FRANCESCHI, Humberto M. A Casa Edison e seu tempo. Rio de Janeiro: Sarapuí, 2002. p. 183. 
31. O maxixe. SANTOS, Alcino; BARBALHO, Gracio; SEVERIANO, Jairo; AZEVEDO, Miguel Ângelo de (Nirez). Discografia brasileira 78 rpm - 1904 a 1964. 5 v.1. Rio de Janeiro: FUNARTE, 1982, p. 125. Para a data de gravação: FRANCESCHI, Humberto M. A Casa Edison e seu tempo. Rio de Janeiro: Sarapuí, 2002. p. 180-183.

32. Toreador. SANTOS, Alcino; BARBALHO, Gracio; SEVERIANO, Jairo; AZEVEDO, Miguel Ângelo de (Nirez). Discografia brasileira 78 rpm - 1904 a 1964. 5 v.1. Rio de Janeiro: FUNARTE, 1982, p. 125. Para a data de gravação: FRANCESCHI, Humberto M. A Casa Edison e seu tempo. Rio de Janeiro: Sarapuí, 2002. p. 180-183.

33. A gloriosa Bandeira. Acervo discográfico de Miguel Ângelo de Azevedo - Nirez Fortaleza CE.

34. Fremido d'amore. SANTOS, Alcino; BARBALHO, Gracio; SEVERIANO, Jairo; AZEVEDO, Miguel Ângelo de (Nirez). Discografia brasileira 78 rpm - 1904 a 1964. 5 v.1. Rio de Janeiro: FUNARTE, 1982, p. 125. Para a data de gravação: FRANCESCHI, Humberto M. A Casa Edison e seu tempo. Rio de Janeiro: Sarapuí, 2002. p. 180-183.

35. Pisando em ovos. SANTOS, Alcino; BARBALHO, Gracio; SEVERIANO, Jairo; AZEVEDO, Miguel Ângelo de (Nirez). Discografia brasileira 78 rpm - 1904 a 1964. 5 v.1. Rio de Janeiro: FUNARTE, 1982, p. 125. Para a data de gravação: FRANCESCHI, Humberto M. A Casa Edison e seu tempo. Rio de Janeiro: Sarapuí, 2002. p. 180-183.

36. A vassourinha. SANTOS, Alcino; BARBALHO, Gracio; SEVERIANO, Jairo; AZEVEDO, Miguel Ângelo de (Nirez). Discografia brasileira 78 rpm - 1904 a 1964. 5 v.1. Rio de Janeiro: FUNARTE, 1982, p. 125. Para a data de gravação: FRANCESCHI, Humberto M. A Casa Edison e seu tempo. Rio de Janeiro: Sarapuí, 2002. p. 180-183.

37. Atraído por uma flor. SANTOS, Alcino; BARBALHO, Gracio; SEVERIANO, Jairo; AZEVEDO, Miguel Ângelo de (Nirez). Discografia brasileira 78 rpm - 1904 a 1964. 5 v.1. Rio de Janeiro: FUNARTE, 1982, p. 125. Para a data de gravação: FRANCESCHI, Humberto M. A Casa Edison e seu tempo. Rio de Janeiro: Sarapuí, 2002. p. 180-183. 


\section{ANEXO II - ENCARTE}

\section{1 - Banda de Música da Força Pública SP}

Faixa 1. A vassourinha - Felipe Duarte

Faixa 2. Amor saudoso - autor não identificado

Faixa 3. Ao clarão da lua - Maestro Antão

Faixa 4. Atraído por uma flor - Maestro Antão

Faixa 5. Coalhada - autor não identificado

Faixa 6. Japonês - Luiz Silva

Faixa 7. Manuelita - autor não identificado

Faixa 8. O maxixe - Grevista

Faixa 9. Rio Branco - autor não identificado

Faixa 10. Titita - autor não identificado

Faixa 11. Tudinha - autor não identificado

Faixa 12. Valsa lenta do maestro Osvaldo - Maestro Osvaldo

Faixa 13. Viúva alegre - Franz Lehar

\section{2 - Banda Ettore Fieramosca}

Faixa 1. Bela Chilena - Ernesto Belucci

Faixa 2. Desfolhando rosas - autor não identificado

Faixa 3. Los toreros - autor não identificado

Faixa 4. Noventa e dois - N. Glória

Faixa 5. Paulistinha - autor não identificado

Faixa 6. Quanto dói uma saudade - N. Glória

Faixa 7. Rédea solta - Otávio Dutra

Faixa 8. Segredo - autor não identificado

Faixa 9. Sonho perigoso - autor não identificado

\section{3 - Banda Giuseppe Verdi e Banda Veríssimo Glória}

Faixa 1. Brasil unido - Banda Giuseppe Verdi - Luiz Forlim

Faixa 2. Trianeiras - Banda Giuseppe Verdi - N.N. 
Faixa 3. América - Banda Veríssimo Glória - Francisco Americano

Faixa 4. Didinha - Banda Veríssimo Glória - Ruriz

Faixa 5. O Conscrito - Banda Veríssimo Glória - Otávio Dutra

Faixa 6. Os Vianas - Banda Veríssimo Glória - N. Glória

Faixa 7. Valadino - Banda Veríssimo Glória - S. Vaz 